$$
\begin{gathered}
\text { UNIVERSIDADE DE SÃO PAULO } \\
\text { FACULDADE DE FILOSOFIA LETRAS E CIÊNCIAS HUMANAS } \\
\text { DEPARTAMENTO DE HISTÓRIA } \\
\text { PROGRAMA DE PÓS-GRADUAÇÃO EM HISTÓRIA SOCIAL }
\end{gathered}
$$

RODRIGO APARECIDO DE ARAÚJO PEDROSO

\title{
VESTINDO AINDA MAIS A BANDEIRA DOS EUA: \\ O Capitão América pós-atentados de 11 de setembro
}

\author{
Versão Corrigida
}




\title{
VESTINDO AINDA MAIS A BANDEIRA DOS EUA: \\ O Capitão América pós-atentados de 11 de setembro
}

\author{
Versão Corrigida
}

Dissertação apresentada à Faculdade de Filosofia Letras e Ciências Humanas da Universidade de São Paulo para a obtenção do título de Mestre em História Social

Orientador: Prof. Dr. Marcos Antonio da Silva 
PEDROSO, Rodrigo Aparecido de Araújo.

Vestindo ainda mais a bandeira dos EUA

Dissertação apresentada à Faculdade de Filosofia Letras e Ciências Humanas da Universidade de São Paulo para a obtenção do título de Mestre em História Social

Aprovado em:

Banca Examinadora

Prof. Dr. Instituição:

Julgamento: Assinatura:

Prof. Dr. Instituição:

Julgamento: Assinatura:

Prof. Dr. Instituição:

Julgamento: Assinatura: 


\section{AGRADECIMENTOS}

Gostaria de agradecer a todos que, de alguma forma, me ajudaram e apoiaram na realização dessa pesquisa. Em especial, à minha família, que sempre me apoia (mesmo quando não entende o que estou fazendo).

Ao meu orientador, Marcos Antonio da Silva, por acreditar e apoiar essa pesquisa. À minha amiga e orientadora, Lilian Grisolio, nem sei como agradecer toda a ajuda que você me deu. À professora, Maria Amélia Mascarenhas Dantes, muito obrigada por ter me cedido uma de suas vagas. Ao professor, Robert Sean Purdy, pelos conselhos e indicações para a melhoria deste trabalho. À professora Mary Anne Junqueira.

Aos colegas da PUC, Camila Petroni, Henry Albert e Alexandre Rossi Carneiro, valeu pela ajuda e conselhos. Aos meus colegas da escola municipal, "Dr. Rabindranath Tagore", obrigado pelo apoio. Aos meus amigos de longa data, Daniel (Cuco), Rebeka G. Dias, Eduardo (Duzão) e Anderson (Dino), Luizão e João. A meus amigos de Franca, Letícia Almeida, Cleiton e Tiago Morato.

A todos os anônimos que se dão ao trabalho de digitalizar histórias em quadrinhos, antigas e novas, e depois as compartilham, gratuitamente, na internet. A todas as bandas de Death e Heavy Metal que me proporcionaram a trilha sonora adequada para o desenvolvimento desta pesquisa.

Por fim, um agradecimento especial à minha sogra Lígia, que fez a revisão deste trabalho. E um agradecimento mais do que especial à minha esposa, Suryah, por todo seu apoio, carinho e compreensão (sem falar das revisões e sugestões), ao longo desses anos de pesquisa. 


\section{RESUMO}

O presente trabalho tem como objetivo analisar como os atentados de 11 de setembro de 2001 foram representados em uma série de histórias em quadrinhos (HQs) do Capitão América, escrita por John Ney Rieber e desenhada por John Cassaday, publicadas entre junho e dezembro de 2002, nos EUA. Essas HQs dialogam com diversos problemas que incomodavam a sociedade norte-americana no período pós-atentados como, por exemplo, os sentimentos de medo, insegurança, vingança e a recém-lançada Guerra ao Terror. Estes são discutidos e interpretados, partindo de dois pontos de vista diferentes, o do Capitão América e o dos terroristas, ou seja, as HQs procuraram expor as justificativas dos dois lados envolvidos. Elas expõem diversas críticas às ações bélicas dos Estados Unidos e também dos terroristas e têm um forte caráter pacifista. Além disso, divulgam uma mensagem de esperança pautada nas ideias do Sonho Americano, que deve ser entendido como uma força de união e mobilização nacional, visando à superação de todos os problemas causados pelos atentados de 11 de setembro.

Palavras-chave: atentados de 11 de setembro. histórias em quadrinhos. Capitão América. história dos Estados Unidos. Sonho Americano. Guerra ao Terror. 


\begin{abstract}
This study aims to analyze how the attacks of September 11, 2001 were represented in a series of Captain America comics, written by John Ney Rieber and drawn by John Cassaday, published between June and December 2002 in USA. These comics dialogue with various problems that bothered the American society in the post-attack period, for example, the feelings of fear, insecurity, revenge and the newly launched War on Terror. These are discussed and interpreted, from two different points of view, that of Captain America and the terrorists, in other words, the comics sought to expose the reasons on both sides involved. They expose several criticisms of the military actions of the United States and also the terrorists and have a strong pacifist character. Moreover, disseminate a message of hope ruled by ideas of the American Dream, which must be understood as a force for unity and national mobilization, aimed at overcoming all the problems caused by the September 11 attacks.
\end{abstract}

Keywords: Sept. 11 attacks. comics. Captain America. U.S. history. American Dream. War on Terror. 


\section{SUMÁRIO}

\section{INTRODUÇÃO - p.8}

\section{CAPÍTULO 1 - O EVENTO}

1.1 Os Estados Unidos e o início do governo de George W. Bush - p.21

1.2 Tragédia, medo, raiva, insegurança e vergonha - p.23

1.3 Criando um "novo" Capitão América - p.27

1.4 O "novo" Capitão América traz esperança a uma nação fragilizada - p.33

1.5 Culpa X Inocência - p.47

\section{CAPÍTULO 2 - INIMIGOS}

2.1 Um breve histórico das lutas do Capitão América e seus inimigos - p.62

2.2 Criando um inimigo - p.71

2.3 Preconceitos com relação à religião muçulmana - p.79

2.4 Capitão América antipatriótico? - p.90

\section{CAPÍTULO 3 - SONHO AMERICANO}

3.1 Um suporte ideológico para solucionar a crise gerada pelos atentados de 11 de setembro - p.98

3.2 Os heróis do Sonho Americano: o "soldado cidadão" e o cowboy - p.112

CONCLUSÕES, PERSPECTIVAS - p.127

REFERÊNCIAS BIBLIOGRÁFICAS - p.132

FONTES (QUADRINHOS) - p.141 


\section{INTRODUÇÃO}

Esta pesquisa tem como objetivo analisar uma importante experiência da história recente dos Estados Unidos: os atentados de 11 de setembro de 2001. O elevado número de vítimas que ele provocou (aproximadamente $5 \mathrm{mil}$ ), a grande extensão dos danos materiais e não materiais fizeram desse evento trágico um marco na história dos Estados Unidos. Em 11 de setembro, os norte-americanos foram expostos a um ataque de extrema violência, com a qual a maioria da população nunca havia tido contato antes, exceto nas telas de cinema. Pela primeira vez, em muitos anos, eles, os Estados Unidos, foram atacados em seu próprio território ${ }^{1}$. Sentimentos de medo e insegurança, reforçados pela ampla cobertura que a mídia deu sobre o ocorrido, foram as consequências imediatas desse trágico dia.

Pouco tempo depois, ao sentimento de medo e insegurança, somou-se um sentimento de vingança, era necessário "vingar" as vítimas, era preciso descobrir quem foi o responsável e fazê-lo pagar por esse crime hediondo. Isto desencadeou a chamada "Guerra ao Terror", que resultou na invasão do Afeganistão e, posteriormente, em 2003, do Iraque, nações acusadas de abrigar ou financiar grupos terroristas de orientação islâmica radical, como a Al-Qaeda.

Devido a tudo isso, os atentados foram exaustivamente explorados pelos meios de comunicação. Os cidadãos dos EUA e do mundo inteiro se viram em meio a uma avalanche dos mais variados tipos de informações que forneciam, desde imagens sensacionalistas do sofrimento de parentes de vítimas, até as mais espantosas e infundadas especulações conspiratórias sobre qual seria a "verdade" oculta em relação à autoria dos atentados.

Em meio a toda essa profusão de "informações", escolhemos como fontes uma série de histórias em quadrinhos do Capitão América, escrita e desenhada, respectivamente, por John Ney Rieber e John Cassaday, e que foram publicadas entre junho e novembro de $2002^{2}$. O foco principal dos autores nessa série foi imaginar como o personagem se adaptaria e reagiria às questões que os atentados colocaram em pauta. As HQs abordam temas que estavam em evidência no período, como as consequências dos ataques e a Guerra ao Terror, e discutem questões identitárias, como: o que é ser um norte-americano nesse novo contexto hostil, porque há um aparente ódio aos Estados Unidos e qual deve ser o novo papel dos Estados Unidos nessa atual configuração mundial. Além disso, indicam que os valores de

\footnotetext{
${ }^{1}$ A última vez que os EUA sofreram um ataque desse tipo foi em 1941, quando a base militar de Pearl Harbor, localizada no Havaí, foi vítima de um ataque surpresa de tropas japonesas e isto deu início à intervenção norteamericana na Segunda Guerra Mundial.

${ }^{2}$ No Brasil, essa série foi publicada nas revistas: Marvel 2002 da edição 9 a 12 (entre setembro e dezembro de 2002) e Marvel 2003 edições 3 e 4 (março e abril de 2003), pela editora Panini Brasil.
} 
autodeterminação e liberdade do chamado "Sonho Americano" podem ajudar a solucionar os problemas pelos quais eles estavam passando.

A escolha de histórias em quadrinhos como fontes e o recorte temporal para essa pesquisa, relaciona-se com várias questões acadêmicas e pessoais. Assim, vamos expor as principais questões que envolvem o uso desse tipo de meio de comunicação como fonte histórica e outras questões que motivaram esta pesquisa. Discutiremos algumas obras de autores que fornecem subsídios para a realização deste trabalho.

A primeira questão que motiva esta pesquisa é o interesse pessoal por histórias em quadrinhos, a escolha delas deve-se a uma longa e passional relação que possuo com esses meios de comunicação. Leio e coleciono quadrinhos desde que fui alfabetizado, entretanto, não possuo uma grande coleção, pois me desfiz de muitas das edições. A princípio, lia quadrinhos unicamente como forma de diversão e fuga momentânea da realidade; com o passar do tempo, percebi que elas transmitiam mensagens e opiniões sobre diversos temas. Um exemplo desse momento de descoberta é uma edição da revista do Incrível Hulk ${ }^{3}$, na qual um personagem amigo do Hulk descobre que está com $\operatorname{AIDS}^{4}$ e vê no herói verde e de sangue radioativo uma esperança para livrar-se de sua doença. A trama aborda uma questão ética, onde Hulk tem que decidir se ajuda seu amigo a vencer a AIDS, mas, ao mesmo tempo, condenaria seu amigo a viver "amaldiçoado" com o sangue radioativo ${ }^{5}$ do Hulk nas veias. Essa HQ aborda outras questões referentes ao preconceito que se tem com relação aos portadores do vírus da AIDS, transmitindo uma mensagem de respeito às diferenças.

Isso é apenas um pequeno exemplo das diferentes temáticas sociais que são abordadas nas histórias em quadrinhos. Há inúmeras outras com as quais os autores desse meio de comunicação costumam lidar. Evidentemente, nem todos trabalham com temáticas sociais ou políticas, muitos optam por temas ligados ao mundo da fantasia, fábulas, contos de fadas, temas recorrentes nos quadrinhos baseados em personagens de Walt Disney ${ }^{6}$, entretanto, todas

\footnotetext{
${ }^{3}$ Personagem criado em 1962 por Jack Kirby e Stan Lee. De forma resumida: o Hulk é um monstro verde (originalmente cinza) que surgiu a partir do momento que o cientista Dr. Robert Bruce Banner foi acidentalmente exposto à radiação gama proveniente de uma bomba que ele mesmo desenvolveu. O Hulk é um personagem que mais causa danos do que ajuda as outras pessoas, pois quando transformado o Dr. Banner tem pouco ou nenhum controle sobre suas ações.

${ }^{4}$ Essa história foi publicada no Brasil na edição 164 da revista "O Incrível Hulk", maio de 1997; a versão original é de agosto de 1994 e saiu na edição 420 da revista Incredible Hulk.

${ }^{5}$ No mundo dos quadrinhos é um fato conhecido que se alguém receber uma transfusão de sangue do Hulk pode sofrer o mesmo tipo de metamorfose que o Dr. Robert Bruce Banner sofre quando fica nervoso e se transforma no Hulk. Um exemplo disso ocorreu quando Bruce Banner doou sangue a sua prima Jennifer Walters e ela se transformou na "Mulher-Hulk" (She-Hulk).

${ }^{6}$ Os quadrinhos e os personagens de Disney foram analisados na obra "Para ler o Pato Donald: comunicação de massa e colonialismo" de Ariel Dorfman e Armand Mattelart, publicada originalmente em 1971. Em suas análises os autores enfatizam o quanto os personagens de Disney contribuem para a divulgação dos valores
} 
podem ser alvo de algum tipo de estudo acadêmico. Existe uma quantidade considerável de trabalhos nas áreas de Semiótica, Sociologia, Pedagogia, Comunicação e Artes que analisam diversos aspectos das histórias em quadrinhos, inclusive esse espectro temático.

Uma obra internacional de referência nos estudos desse meio de comunicação é “Apocalípticos e integrados”, de Umberto Eco, edição original de 1964. O autor nos apresenta vários ensaios sobre meios de comunicação de massa, dos quais três são dedicados à análise de histórias em quadrinhos - dos personagens Steve Canyon, Superman e "Minduim" (Peanuts) -, demonstrando o quanto elas podem representar e discutir questões sociais, políticas, morais, psicológicas, etc... De maneira geral, o foco de suas análises está na decodificação da "mensagem"7 que as HQs transmitem. Além disso, Eco analisa a construção e funcionamento das estruturas narrativas desse meio de comunicação, fornecendo importantes dados para desenvolvermos uma metodologia de análise.

No Brasil, os primeiros trabalhos de análise de histórias em quadrinhos surgiram nos anos de 1970. Vale citar as obras de Moacy Cirne, como "A explosão criativa dos quadrinhos" (1970) e "Para ler os quadrinhos" (1972) que expõem o quanto é variado o universo temático das histórias em quadrinhos e fornecem uma análise de como elas podem ser lidas e interpretadas de um ponto de vista social e político. Muitos artigos de Cirne foram publicados na "Revista de Cultura Vozes" que, nos anos 70, foi um importante veículo de divulgação de trabalhos sobre HQs e de outros meios de comunicação. A revista abriu um grande espaço para o estudo de HQs, publicando em várias de suas edições (algumas especiais sobre HQs) artigos de autores que analisavam múltiplos aspectos dessa linguagem. Vários desses artigos também fornecem dados relevantes para a realização desta pesquisa.

Outro trabalho pioneiro entre nós, na análise de histórias em quadrinhos, é o de Álvaro de Moya, que em 1972, lançou a coletânea de artigos e ensaios "SHAZAM!", na qual podemos ter contato com diferentes trabalhos sobre HQs e cujo foco da maioria dos textos é fazer uma retrospectiva histórica de como esse meio de comunicação foi se desenvolvendo no exterior e no Brasil.

Além desses autores, vale citar o trabalho desenvolvido por Waldomiro Vergueiro, professor da Escola de Comunicação e Artes da USP, que possui várias obras publicadas

capitalistas e do chamado "American Way of Life" [modo de vida americano]. No livro há apontamentos interessantes, entretanto, as análises são demasiadamente parciais, e deixam a impressão de que não há nada de "bom" ou útil nessas HQs.

${ }^{7}$ Eco considera que o objetivo dos "meios de comunicação de massa" é transmitir mensagens a uma "civilização de massas" assim sendo [...] "todos que pertencem à comunidade se tornam, em diferentes medidas, consumidores de uma produção intensiva de mensagens jato contínuo, elaboradas industrialmente em série e transmitidas, segundo canais comerciais de um consumo regido pela lei da oferta e da procura." (ECO, 2008, p.27). 
sobre quadrinhos e suas múltiplas possibilidades de pesquisa, além de coordenar um grupo de estudos acadêmicos sobre HQs - "O Observatório de Quadrinhos”.

Há também trabalhos mais recentes como o livro "A guerra dos gibis" (2004), do jornalista Gonçalo Junior, que fornece um panorama histórico do desenvolvimento e das controvérsias, envolvendo as publicações desse meio de comunicação no Brasil. O livro oferece ainda uma amostra de como acontecimentos nos Estados Unidos, citando: a criação do Comics Code Authority ${ }^{8}$, interferiram nas publicações aqui. Os temas abordados na obra de Gonçalo nos ajudam a entender melhor como funciona o mercado das histórias em quadrinhos e a relação entre autores/artistas de quadrinhos e as editoras que publicam seus trabalhos.

Essas obras e autores citados, juntamente com alguns artigos, teses e dissertações que não citaremos, ${ }^{9}$ nesse momento, evidenciam que as histórias em quadrinhos possuem um grande potencial como objetos de análises acadêmicas nas mais diversas áreas. Todavia, no campo da história, o uso de histórias em quadrinhos como fontes ainda é pequeno.

Entretanto, no campo da História vale destacar o pioneirismo do historiador, Marcos Antonio da Silva, que, em 1989, publicou o livro "Prazer e poder do Amigo da Onça", obra na qual analisa o personagem "Amigo da Onça”, criado pelo artista, Péricles de Andrade Maranhão, e procura traçar as principais relações existentes entre as charges e quadrinhos do personagem e o contexto social e político do Brasil, no período de 1943 a 1962, demonstrando como esse meio de comunicação pode fornecer indícios para interpretar sentimentos e angústias de um determinado período. Outro trabalho do autor, que é de grande relevância para esta pesquisa, é o artigo "Machos \& Mixos. Henfil e o fim da Ditadura Militar (Brasil, anos' 80)" (1998), pois fornece um exemplo prático de como analisar HQs de um ponto de vista historiográfico.

É a partir desses dados que se constitui a segunda questão que motiva esta pesquisa: por que usar histórias em quadrinhos como fontes? Essa questão está ligada a outra problemática historiográfica mais ampla: O que é ou não possível de ser utilizado como fonte histórica? Esse é um tema já bem debatido por historiadores e, de certa forma, pode-se afirmar que desde os estudos da chamada Escola dos Annales, na primeira metade do século XX, as fontes que um historiador pode usar para desenvolver suas pesquisas não possuem uma delimitação específica - exceto a disponibilidade de materiais do período que se pretende

\footnotetext{
${ }^{8}$ Código de autocensura desenvolvido pelas editoras de quadrinhos nos EUA, nos anos de 1950, estabelecia o que poderia ou não ser publicado nas HQs. Violência, drogas, sexo, nudez etc., eram algumas das coisas que não podiam ser divulgadas.

${ }^{9}$ Faremos referências a esses trabalhos no decorrer desta dissertação.
} 
estudar e a imaginação do pesquisador. Assim sendo, dependendo do que se pretende estudar, a escolha das fontes mais apropriadas cabe unicamente ao historiador.

Um dos primeiros trabalhos historiográficos internacionais, do qual temos conhecimento, a utilizar histórias em quadrinhos como fonte é do historiador francês, Michel Vovelle, em seu livro "Imagens e Imaginário na História: Fantasmas e Certezas nas Mentalidades desde a Idade Média até o Século XX”, publicado, originalmente, em $1987^{10}$. Nessa obra, Vovelle apresenta uma série de artigos nos quais ele explora diversos tipos de representações iconográficas e onde os temas principais são: a Revolução Francesa e a iconografia sobre a morte em diversos períodos. Os quadrinhos são usados por ele para fazer uma análise das representações sobre a morte em nossos dias. Ele propõe que os quadrinhos são comumente caracterizados como uma forma de:

[...] literatura angustiada, reflexo de criações fantásticas da atualidade que, em contraposição, difundiria seus produtos? Ou literatura de alienação, relaxante pela válvula de escape que representa para as pulsões elementares, ou geradora da boa consciência e de uma nova ordem extraterrestre a preço acessível. (VOVELLE, 1997, p.386-387)

Entretanto, ele considera que essas características não são motivos para não se estudar esse meio de comunicação. E para realizar suas análises, o autor estabelece as seguintes questões:

[...] Quem as lê? Que se percebe nelas? As histórias ilustradas que o empregado nova-iorquino e os desocupados franceses e italianos compram para matar o tédio, além de ser uma ocupação lúdica de quinze minutos, não são também o reflexo de um modo de sentir coletivo? (Ibidem)

Partindo dessas indagações, Vovelle demonstra que as HQs podem fornecer uma visão parcial de como um determinado período se representa, expondo suas angustias com relação à morte, no caso do recorte temático dele. Mas, como já dissemos antes, as HQs também podem fornecer informações sobre como outras questões sociais e culturais contemporâneas são representadas.

Vovelle procura não diferenciar as histórias em quadrinhos de outros tipos de imagens. E, quanto ao potencial que as imagens têm como fontes históricas, ele faz as seguintes colocações:

Quer se coloque na perspectiva de uma história de longa duração, registrando as mudanças das mentalidades coletivas e das criações do imaginário dentro da continuidade dos derivados plurisseculares, quer se coloque no tempo curto de uma dessas crises, com ou sem forma de revolução, que escondem e ao mesmo tempo quebram o ritmo dessa aventura, a imagem no sentido mais amplo do termo, transmite um testemunho privilegiado, tanto direto como oblíquo, massificado ou único.

\footnotetext{
${ }^{10}$ No Brasil o livro foi publicado em 1997 pela Editora Ática.
} 
Muito mais do que uma ilustração acompanhando e comentando, a imagem tornou-se parte integrante da elaboração de um discurso que não pode prescindir dela. (VOVELLE, 1997, p.31, grifo nosso)

Esse trecho fornece as principais diretrizes que guiam esta pesquisa, pois pretendemos - dentro das especificidades de nossas fontes - analisar como a crise gerada pelos ataques de 11 de setembro foi representada nas HQs do Capitão América, que é um evidente símbolo contemporâneo dos Estados Unidos. Ao mesmo tempo, queremos incluir este imaginário narrativo em uma perspectiva de longa duração no que diz respeito ao mito do "American Dream" [Sonho Americano], que é apontado nas HQs como elemento que pode ajudar os norte-americanos a superar essa nova crise.

Vale ressaltar que as HQs apresentam todas as formas de "testemunho" que Vovelle diz que uma imagem pode conter. As HQs são frutos do trabalho de determinados artistas que, ao venderem sua força criativa a uma empresa especializada nesse ramo de comunicação, produzem obras nas quais podem expor suas opiniões e as da empresa sobre vários assuntos, e ao mesmo tempo, há uma preocupação de divulgar ideias que sejam atraentes para serem consumidas por um vasto público.

Além dessa obra de Vovelle, há três congêneres norte-americanas que consideramos relevantes para o desenvolvimento desta pesquisa.

A primeira é "Commies, Cowboys, and Jungle Queens: Comic Books and America, 1945-1954”, do historiador William W. Savage Jr., publicada em 1998. O autor afirma que ainda há um grande preconceito sobre as histórias em quadrinhos, elas costumam ser consideradas um produto barato, sem importância, descartável e que está associado ao mundo infantil e pré-adolescente, por isso, não poderiam fornecer dados confiáveis sobre o período em que foram produzidas. Savage rebate essa ideia preconceituosa sobre as HQs ao explicar que a intenção de seu livro é demonstrar que

\begin{abstract}
mesmo a mais efêmera e aparentemente inconsequente literatura [...] pode nos contar muito sobre a sociedade que as produziu e abrigou. As crianças podem ter lido os quadrinhos, mas, eles foram escritos e desenhados por adultos; e dessa simbiose uma síntese desse período pode emergir - não para ficar sozinha, com certeza, mas para ser empregada em contextos existentes e contribuir para o entendimento de quem nós fomos e, consequentemente, quem somos. (SAVAGE, 1998, p. x, tradução nossa) ${ }^{11}$
\end{abstract}

\footnotetext{
11 “ $[\ldots]$ even the most ephemeral and seemingly inconsequential literature [...] can tell us a lot about the society that produced them and housed. Children may have read the comics, but they were written and designed by adults; and this symbiosis an overview of this period can emerge - not to be alone, to be sure, but to be used in existing contexts and contribute to the understanding of who we were and therefore who we are." (SAVAGE, 1998, p.x).
} 
Assim, percebe-se que há uma consonância entre os argumentos de Savage e Vovelle, ambos defendem que, por mais "efêmeras" que as histórias em quadrinhos sejam, elas podem fornecer amostras de como determinada sociedade se representou. Além disso, Savage critica o que ele chama de "acadêmicos com tendências a um elitismo cultural", que não dão importância alguma a meios de comunicação de massa, como as HQs. Para ele, os meios de comunicação de massa atingem muito mais pessoas do que os textos clássicos da literatura, ou outros tipos de fontes que os historiadores costumam preferir. Ele deixa claro que não está dizendo que este e outros tipos de documentação mais "clássicos" não devam ser analisados, simplesmente está sugerindo:

outra categoria de documentos, outra janela para a experiência Americana; e gostaria de exortar os céticos de recordar o tempo, não muito tempo atrás, quando a relação entre história e, digamos, o cinema teria sido considerada inadequada para o discurso acadêmico. Em suma, se o material existe e pode ser útil, por que não usá-lo. (Ibidem, p. x-xi, grifo e tradução nossa) ${ }^{12}$

O autor ainda argumenta que a intenção de seu trabalho é mostrar como as histórias em quadrinhos podem ser usadas como "fontes primárias" para entender - no caso de seu recorte, as preocupações que predominavam nos Estados Unidos do pós-guerra.

A proposta de trabalho histórico de Savage pode ser ampliada para outros contextos dos EUA, e é exatamente isso que o historiador Bradford W. Wright faz em seu livro "Comic Book Nation: The Transformation of Youth Culture in America" (2003). De modo geral, Wright conta a história das principais mudanças culturais dos Estados Unidos por meio da análise de diversas histórias em quadrinhos. Ele começa em 1933, quando surgem as primeiras HQs de super-heróis enquanto os americanos lutavam para se recuperar da crise de 1929, até o ano de 2001, quando os Estados Unidos sofreram o atentado em 11 de setembro. Wright aborda diversos temas, como Segunda Guerra, Guerra Fria, movimentos por direitos civis, mudanças no comportamento dos jovens e as consequências do 11 de setembro.

Esse autor segue a mesma linha de pensamento que Savage, ele também compreende que as histórias em quadrinhos possuem um grande potencial representativo das transformações pelas quais a sociedade norte-americana tem passado. O diferencial da pesquisa de Wright está em sua abordagem mais ampla, analisando diversos personagens e temas, com isso, pode-se dizer que seu trabalho conta a História dos Estados Unidos a partir das HQs. O autor diz que sua pesquisa com HQs procura demonstrar como esse meio de

\footnotetext{
12 " [...] another category of documents, another window to the American experience; and I would urge skeptics to remember the time not long ago when the relationship between history and, say, the film would have been considered inappropriate for academic discourse. In short, if the material exists and can be useful, why not use it. (SAVAGE, 1998, p. x-xi).
} 
comunicação, "efêmero e aparentemente sem importância", é importante para a compreensão de muitas das mudanças culturais que ocorreram nos Estados Unidos, ao longo do século XX. Além disso, ele cita as seguintes questões que norteiam seu trabalho:

Como é que fatores políticos, culturais e econômicos se intersectam na criação das histórias em quadrinhos? O que as histórias em quadrinhos sugerem sobre as mudanças no mundo dos jovens? Como a história dessas histórias em quadrinhos pode contribuir para o entendimento de nossa própria cultura de consumo? Qual o significado delas para a cultura americana? (WRIGHT, 2003, p.xi, tradução nossa) ${ }^{13}$

Assim, pode-se dizer que o estudo de Wright nos fornece importantes análises sobre diversos contextos históricos dos EUA, demonstrando como as HQs podem ser usadas em trabalhos com um recorte temporal mais amplo. Além disso, as análises que ele faz sobre a configuração das HQs após o 11 de setembro serão úteis para que possamos constituir nossas reflexões acerca do tema.

O livro "Secret Identity Crisis: Comic Books \& the Unmasking of Cold War America" (2009) de Matthew J. Costello, também trabalha com um período de tempo longo, sua proposta é analisar como a Guerra Fria afetou e foi representada nas histórias em quadrinhos. Para tanto, ele analisa várias histórias em quadrinhos da editora Marvel Comics. Além disso, suas análises não se limitam somente ao contexto da Guerra Fria (1945-1989), o pesquisador ultrapassa esse limite cronológico e também analisa os reflexos do 11 de setembro nas HQs. Logo no início da introdução, Costello afirma que "Como outras formas de entretenimento popular, as histórias em quadrinhos tendem a serem muito receptivas às tendências culturais, para refleti-las, comentá-las e às vezes inaugurá-las. " (2009, p.01, tradução nossa). ${ }^{14}$

O autor também fornece importantes informações sobre a editora Marvel Comics (que detém os direitos de publicação do Capitão América), especificamente sobre as "inovações" que ela introduziu nos anos de 1960, na forma como as HQs de super-heróis eram produzidas e também na "personalidade" de seus personagens superpoderosos, que passaram a ter um ar mais realista. Muitos deles, como o Homem-Aranha, eram representados como pessoas comuns que, entre uma luta e outra, contra um supervilão, tinham que lidar com problemas corriqueiros da maioria dos seres humanos, por exemplo, pagar contas, lavar roupa, arrumar uma namorada(o) etc... Além disso, as histórias passaram a ser situadas em locais reais, especificamente Nova York, não em cidades fictícias como Metropolis do Super-Homem ou

\footnotetext{
13 "How have political, cultural, and economic factors intersected to make comic books? What do comic books suggest about the changing world of young people? How does the history of these comic books contribute to our understanding of consumer culture? What is their significance in American culture?" (WRIGHT, 2003, p. xi).

14 "Like other forms of popular entertainment, comic books tend to be very receptive to cultural trends, to reflect them, comment on them, and sometimes inaugurate them." (COSTELLO, 2009, p.01).
} 
Gotham City do Batman. Assim, esses "quadrinhos estavam conscientemente situados em um contexto contemporâneo [...]. Isso iria criar uma grande oportunidade para comentários culturais direcionados. " (COSTELLO, 2009, p.11, tradução nossa). ${ }^{15}$

Esses e outros apontamentos feitos por Costello, em seu livro, nos fornecem dados para que possamos entender o Capitão América como produto de um amplo contexto de mudanças culturais e editoriais. Quando as HQs do personagem voltaram a ser publicadas no ano de $1964^{16}$, o Capitão foi modificado para se enquadrar no perfil dos demais personagens da editora, mesmo sendo um personagem "mais antigo", sua constituição ficcional ganhou atributos mais "humanizados", problemas e contradições pessoais passaram a fazer parte de suas ações heroicas.

As obras citadas demonstram a viabilidade do uso de histórias em quadrinhos como fontes históricas e nos fornecem indicações metodológicas sobre como analisar este meio de comunicação, porém esta pesquisa tem uma perceptiva mais pontual de análise. Em vez de utilizarmos uma grande quantidade de HQs para determinar e analisar mudanças que ocorreram na sociedade norte-americana, como os autores citados fizeram, optamos por um recorte mais "curto" em relação ao período e às fontes, limitados em um período de, aproximadamente, seis meses. Assim, nosso objetivo central limita-se a estabelecer que tipo de "mensagens" essas HQs procuraram transmitir sobre os atentados e a Guerra ao Terror.

Baseamos esta escolha na seguinte afirmação do historiador Michel Vovelle: “ $A$ imagem reflete as agitações do tempo curto, em certos casos reforçando-lhe o traço, mas faz dentro de um quadro determinado no qual se insere o peso de uma herança de longa duração." (1997, p.31). Assim, nossa delimitação "curta" tem como objetivo investigar a fundo como as "agitações" que os atentados de 11 de setembro provocaram foram representados nas HQs. Ao mesmo tempo, procuraremos enquadrar esta representação dentro de seu contexto imediato e de sua "herança de longa duração".

Este recorte temático e temporal nos leva a outra questão discutida e, insuficientemente resolvida, entre os historiadores: a possibilidade de se estudar o "tempo presente”. De maneira geral, a grande questão colocada é: os historiadores devem estudar

\footnotetext{
15 "The books were consciously set in contemporary context [...]. This would create extensive opportunities for direct cultural comment." (Ibidem, p.11).

${ }^{16}$ As HQs do Capitão América haviam sido descontinuadas em 1954, e voltaram a ser publicadas novamente em 1964 quando Stan Lee, um dos escritores responsáveis pela criação dessa "nova" geração de super-heróis "humanizados" da Marvel Comics, reescreveu o passado do personagem dizendo que, no final da Segunda Guerra Mundial, o Capitão havia sido acidentalmente congelado em um iceberg, do qual foi resgatado pelo grupo de super-heróis Os Vingadores (The Avengers). Assim, o Capitão América voltou para o mundo dos "vivos" lutando ao lado dos Vingadores e também sozinho. Esse "renascimento" do herói ocorreu na revista The Avengers número 4 de março de 1964.
} 
somente o que se passou há muitos anos para que se possa ter um devido distanciamento de seu objeto de estudo, ou fatos que ocorreram há pouco tempo - dias, semanas, meses ou há poucos anos - também podem ser analisados de um ponto de vista histórico? A discussão é grande, porém esta pesquisa parte da ideia de que é possível e necessário que historiadores se debrucem sobre questões atuais. Assim, como afirma Chauveau e Tétard, "a história não é somente o estudo do passado, ela também pode ser, com menor recuo e métodos particulares, o estudo do presente." (1999, p.15).

Para estudar a história do "tempo presente", ou "passado recente", é necessário levar algumas questões em consideração, uma delas é que tipos de fontes podem ser utilizados. Vivemos em uma época na qual os eventos ou fatos, importantes ou não, recebem uma vasta cobertura midiática. Notícias sobre determinados eventos são veiculados pelos mais diversos meios de comunicação. O rádio, o cinema, a TV, os jornais, as revistas impressas e, mais recentemente, a internet fornecem diversos tipos de informações e pontos de vista a respeito de um mesmo fato. Assim, o historiador que pretende estudar algum acontecimento do presente se depara com uma abundância de fontes, logo, sua primeira tarefa é selecionar qual se ajusta melhor ao que ele pretende investigar.

Além dessa produção midiática, o historiador também pode fazer uso de documentos mais convencionais, como discursos presidenciais, leis, etc. que, atualmente, também podem ser acessados com relativa facilidade. Portanto, com relação às fontes para a história do "tempo presente", encontramos um vasto registro, isso constitui, ao mesmo tempo, uma vantagem e uma desvantagem, pois determinados fatos apresentam uma quantidade tão grande de fontes que seria praticamente impossível analisar tudo o que existe para a produção de um trabalho acadêmico. Essa "profusão exige escolha e classificação e o rigor do oficio histórico é aqui ainda mais indispensável que alhures." (BERNSTEIN e MILZA, 1999, p.129). A vantagem é que essa abundância pode favorecer uma análise quantitativa mais ampla, entretanto, ambígua. Isto é algo que não é possível, por exemplo, para aqueles que trabalham com História Antiga, Medieval ou outros períodos que possuem escassos registros materiais.

Outra questão importante a ser considerada ao analisar o "passado recente" é a relação entre o historiador e o seu tema. O contexto no qual o historiador está exerce uma forte influência sobre suas análises.

A contemporaneidade, em História, é mais que um campo temático ou um recorte de periodização. Ela é parte constitutiva do próprio conceito de História e se apresenta, teimosamente, até para quem procura fugir dela, abrigando-se em passados mais ou menos remotos e idealizados. 
Lastimavelmente, para esses fugitivos, as contemporaneidades os atacam de múltiplos lados, quer isso lhes seja consciente ou não. (SILVA, 2007, p.3)

Assim sendo, uma das funções de todo trabalho historiográfico é lidar com o presente e com o passado, procurando da melhor maneira possível "separá-los", para não incorrer no grande perigo que ameaça os historiadores: o anacronismo. Entretanto, para quem lida com temas do presente, o problema maior é a completa e inevitável imersão no tempo estudado. Sobre isso, Chauveau e Tétard fazem a seguinte observação:

Essa imersão do historiador do presente em seu tema distingue-se, parecenos, da relação natural que todo o historiador tem com seu tema, seja ela passional ou não. Jamais um medievalista ou um modernista poderá "viver" o que descreve. Ele deve recompor uma realidade que lhe escapa fisicamente. Não é senão no presente, por reverberação de sua relação no presente, que ele pode (re)conhecer ou imaginar aquilo de que fala investindo-o de uma presença fisica "real". A metáfora histórica nasce da associação entre imagens do presente e representações do passado. (1999, p. 31)

Nesse ponto, assim como em estudos de outros temas históricos, deve-se buscar certo distanciamento, para que as análises sejam mais precisas. Para compreender seu tempo e as relações sociais que estão envolvidas,

O historiador deve, pois abstrair-se o mais completamente possível das interferências da ideologia e da subjetividade, estudando-as e procurando apreender verdadeiramente seu objeto além de uma acepção puramente histórica. A epistemologia da história do presente consiste, portanto, em interrogar a história a fim de propor novos dados que aumentarão sua capacidade de explicitação e de sugestão. (CHAUVEAU e TÉTARD, 1999, p.36)

Em síntese, o historiador do "tempo presente" necessita estabelecer um método analítico que lhe permita analisar determinado fato de forma objetiva e que possa fornecer uma compreensão mais precisa. Isso não é fácil e os resultados, assim como o de qualquer trabalho histórico, é suscetível a críticas e contestações que podem levar a novas discussões e interpretações sobre fatos que ainda não tiveram um desfecho. Com relação ao estudo do "tempo presente", a chave para lidar com os problemas que ela apresenta é a escolha de metodologias adequadas que permitam aos historiadores lidarem com os diversos tipos de fontes que estão à disposição atualmente. É preciso, como sugere Bernstein e Milza,

Para fontes novas, novos métodos: a análise de imagens, fixas ou mutáveis, decorre de métodos próprios. $O$ depoimento oral não poderia se restringir à pura e simples transcrição das declarações de testemunhas. A imprensa também não é um puro e simples reflexo da opinião, mas resultado de uma mediação em que o conhecimento do meio de comunicação é essencial. Isto significa que a história do presente é mesmo história, é uma história particularmente delicada para se construir e analisar. (1999, p.130) 
Todos os argumentos expostos, acima, fornecem as principais articulações historiográficas e metodológicas nas quais esta pesquisa procurou se pautar. Quanto à metodologia que usaremos para a análise das HQs, procuraremos interpretar o texto juntamente com as imagens, pois como afirma o artista/teórico de histórias em quadrinhos Will Eisner,

Quando se examina uma obra em quadrinhos como um todo, a disposição de seus elementos assume a característica de uma linguagem. [...] As histórias em quadrinhos comunicam numa "linguagem" que se vale da experiência visual comum ao criador e ao público. (EISNER, 2001, p.07)

Portanto, as HQs possuem uma linguagem única que alia elementos visuais e textuais e, ao se combinarem, dão origem a uma nova forma de linguagem, onde tanto o texto quanto as imagens podem ser interpretadas pelos leitores; estes dois elementos interagem e se complementam, tornando impossível a análise de um deles separadamente, então, faremos uma análise combinada dos mesmos, buscando destacar momentos dentro da narrativa, quando imagens e textos se articulam visando a reforçar ou transmitir ideias, sentimentos, preconceitos ou críticas pertinentes ao contexto social e/ou político pós-atentados de 11 de setembro.

Assim, pode-se dizer que estamos desenvolvendo uma pesquisa de história do "tempo presente", que tem como objetivo principal investigar o imaginário criado sobre os atentados de 11 de setembro nas HQs do Capitão América. Para tanto, este trabalho foi dividido em três capítulos.

No primeiro, abordaremos um pouco do contexto político dos EUA pré-atentados, expondo algumas das principais propostas de governo do presidente Bush. Posteriormente, exporemos algumas questões relacionadas com o desenvolvimento desta série do Capitão América, analisando depoimentos dos autores para que possamos entender melhor quais eram suas propostas. Finalizaremos com a análise de como as consequências traumáticas dos atentados foram representadas nas HQs e como os autores as usaram para divulgar uma mensagem de esperança e, ao mesmo tempo, críticas à política bélica implementada pelo governo Bush e questionaram a ideia de que os EUA não tiveram nenhuma culpa pelo que aconteceu em 11 de setembro.

No segundo capítulo, analisaremos a relação entre o Capitão América e seus inimigos, partindo de uma breve contextualização de como essa interação entre herói e vilão foi se modificando ao longo da existência do personagem. Selecionaremos alguns momentos da história do Capitão América - Segunda Guerra Mundial e Guerra Fria - e analisaremos as 
mudanças na forma de representar e tratar os inimigos reais ${ }^{17}$, para estabelecer um paralelo com a forma que os terroristas e a religião muçulmana foram apresentados nessa nova fase do herói. Além disso, procuraremos investigar algumas das repercussões desses quadrinhos, que devido a suas críticas chegaram a ser acusados de divulgar conteúdo antipatriótico.

Por fim, no terceiro capítulo, trataremos de alguns aspectos do Sonho Americano e sua permanência na sociedade norte-americana como um elemento mítico identitário, de incentivo ao trabalho e promovedor de pensamentos positivos quanto ao futuro, pois nas HQs, ele é usado numa tentativa de mobilizar o povo ou, pelo menos, os leitores da revista a se unirem e superarem as adversidades que os atentados geraram.

Esta divisão apresentada tem como objetivo facilitar a análise das histórias em quadrinhos, pois os temas discutidos pelos autores, ao longo da narrativa, não são apresentados separadamente. A obra é permeada por mensagens patrióticas e de esperança, por críticas diretas e indiretas ao governo; ideias pacifistas; questões identitárias, e preconceitos e propostas de ação. Por isso, em muitos momentos, repetimos e reanalisamos alguns trechos das HQs que apresentam mais de uma interpretação.

Além das HQs, ao desenvolver a dissertação, procuraremos estabelecer comparações com outras fontes sobre o período, como discursos do presidente George W. Bush, o "Ato Patriota" [Patriot Act $]^{18}$ e outros documentos governamentais relevantes. Faremos também a comparação das HQs do Capitão América com outras produções midiáticas e HQs que procuraram retratar os atentados de 11 de setembro.

\footnotetext{
${ }^{17}$ Aqui nos referimos a inimigos que existem fora do mundo ficcional do personagem como os nazistas e os comunistas com os quais o Capitão interagiu ao longo de sua existência.

${ }^{18}$ USA Patriot Act (Uniting and Strengthening America by Providing Appropriate Tools Required to Intercept and Obstruct Terrorism Act of 2001) documento aprovado pelo Congresso em outubro de 2001, que, em linhas gerais, permitiu a violação da privacidade e dos direitos civis dos cidadãos norte-americanos em nome do combate ao terrorismo.
} 


\title{
CAPÍTULO 1 \\ O EVENTO
}

\subsection{Os Estados Unidos e o início do governo de George W. Bush}

\author{
O candidato do partido Republicano George Walker Bush ${ }^{19}$, ex-governador do Texas e
} filho do ex-presidente George Bush (1989-1993), assumiu a presidência dos Estados Unidos em 20 de janeiro de 2001. O processo eleitoral que levou Bush ao poder nos EUA foi marcado por uma grande polêmica envolvendo a contagem de votos no estado da Flórida. O candidato do partido Democrata Al Gore (vice-presidente de Bill Clinton), aparentemente, havia ganhado as eleições, porém depois de uma recontagem de votos no estado da Flórida, constatou-se que quem, de fato, havia conseguido a maioria de votos foi George W. Bush. De acordo com Michael W. Traugott,

O resultado apertado da eleição na Flórida e o fato de este ter sido o último Estado a finalizar a contagem dos votos o tornaram o alvo principal para as equipes de Bush e Gore nas semanas seguintes ao dia da eleição. Devido à natureza local do sistema de eleição americano e ao fato de o colégio eleitoral atribuir seus votos por Estado com base em "o vencedor leva tudo", os dois lados entraram com ações legais nos tribunais do Estado. Cada equipe escolheu os locais onde esperavam obter mais sucesso quanto às questões legais por ela levantadas, assim como por sua capacidade de impugnar determinados tipos de votos. Nenhuma das equipes solicitou a recontagem total dos votos do Estado.

Finalmente, o caso avançou até a Suprema Corte dos EUA para a decisão judicial final, onde ficou decidido que a recontagem deveria ser interrompida e a certificação original do resultado, emitida pela secretária de Estado da Flórida, mantida. Assim, os 25 votos eleitorais da Flórida foram para George W. Bush, dando-lhe a maioria do colégio eleitoral e assegurando-lhe a Presidência. $(2004)^{20}$

Desta maneira, Bush tornou-se o $43^{\circ}$ presidente dos Estados Unidos e, devido aos problemas em sua eleição, o início do mandato foi marcado por uma relativa falta de credibilidade. Muitos, principalmente membros do partido Democrata, o acusavam de ter "roubado" 21 as eleições e de não ter sido, de fato, eleito para presidente. Discutir se realmente

\footnotetext{
${ }^{19}$ Para ter acesso a uma breve biografia de George W. Bush, recomendamos acessar o seguinte web site: <http://www1.folha.uol.com.br/folha/especial/2004/eleicoesnoseua/perfil-george_w_bush.shtml >

${ }^{20}$ Texto de Traugott também explica como funciona o sistema eleitoral dos Estados Unidos e está disponível em: <http://www.embaixada-americana.org.br/elections/procedure.htm> Acesso em: 02/03/2014.

${ }^{21}$ Essas acusações são difíceis de serem comprovadas, na época houve algumas denúncias e investigações que apontavam para uma possível manipulação dos resultados no estado da Flórida envolvendo o irmão do
} 
Bush fraudou as eleições de 2000 não é o nosso objetivo, nós nos limitaremos a analisar como esse período inicial da presidência de George W. Bush foi conturbado e quais eram as principais orientações políticas de seu governo.

Durante sua campanha presidencial em 2000, Bush apresentou diversas promessas que tinham como objetivo "inaugurar uma nova era de responsabilidade" 22 (BUSH, 2000, tradução nossa). Suas promessas abordavam temas como redução de impostos, implementação de novas medidas educacionais, ampliação do acesso a planos de saúde e uma "reconstrução" do exército dos EUA. Nas palavras do então candidato: "Eu irei reconstruir nosso exército, dando-lhe os recursos necessários para cumprir sua responsabilidade de manter a paz. Promoverei uma agenda econômica responsável para dar continuidade a nossa prosperidade." (Ibidem). ${ }^{23}$

Al Gore tinha propostas políticas parecidas com as de Bush, abordando as mesmas preocupações com educação, sistema de saúde e redução de impostos. O diferencial entre as campanhas estava em temas relacionados à proteção do meio ambiente que Bush, nem sequer menciona, e na visão dos candidatos com relação à atuação dos Estados Unidos no exterior. Gore propunha dar continuidade às ações diplomáticas e intervenções promovidas por Bill Clinton, num panfleto de campanha são destacadas as qualidades e a experiência do candidato em negociações diplomáticas:

Ele tem ajudado na redução de arsenais nucleares mortais, a manter
reformas políticas frágeis, a resolver disputas comerciais, e a pavimentar o
caminho para maiores investimentos dos Estados Unidos no exterior através
de intervenções diretas com líderes estrangeiros. (GORE, 2000, tradução
nossa ${ }^{24}$ Já Bush manifestava uma opção política mais voltada para resolver problemas internos e, para evitar que os Estados Unidos sofressem algum tipo de ataque inimigo, ele defendia um maior investimento militar na compra de armas e na construção de um sistema de defesa antimísseis. Um dos panfletos de campanha afirmava que Bush era contra a presença de tropas dos Estados Unidos em outros países, "nenhuma tropa dos EUA deve ser posta em perigo, a

presidente Bush, Jeb Bush, porém, nada foi realmente comprovado. Para uma análise aprofundada dessa questão eleitoral recomendamos a leitura do artigo "The stolen presidential elections" [As eleições presidenciais roubadas] do historiador, Michael Parenti, disponível em: 〈http://www.michaelparenti.org/stolenelections.html〉 Acesso em: 02/03/2014.

${ }^{22} \mathrm{O}$ trecho citado foi retirado do parágrafo inicial de um panfleto de campanha, no qual Bush explica porque quer ser presidente e diz, também, o que pretende fazer se eleito. O panfleto está disponível em:< http://www.4president.org/brochures/georgewbush2000brochure.htm> Acesso em: 02/03/2014.

${ }^{23} \mathrm{O}$ trecho original é o seguinte: "I'll rebuild our military, giving it the resources it needs to meet its responsibility to keep the peace. I'll promote a responsible economic agenda to continue our prosperity."

24 "He has helped to reduce deadly nuclear arsenals, sustain fragile political reforms, resolved trade disputes, and pave the way for far greater U.S. investment abroad through direct intervention with foreign leaders." Disponível em: < http://www.4president.org/brochures/gore2000brochure.htm> Acesso em: 02/03/2014. 
menos que os interesses da América estejam em jogo, e as nossas tropas nunca serão postas sob comando da ONU." (BUSH, 2000, tradução nossa). ${ }^{25}$

Essas promessas de Bush evidenciam seu distanciamento da política internacional estabelecida durante o governo de Bill Clinton. Segundo o historiador Peter Demant,

\begin{abstract}
em janeiro de 2001, George W. Bush chegava ao poder com um programa internacional que se diferenciava do de seu predecessor, Bill Clinton, e de seu concorrente democrata e ex-vice presidente Al Gore ao enfatizar o unilateralismo, a rejeição a embaraços estrangeiros e a recusa a "construção da sociedade civil" em nações recentemente democráticas[...] $O$ novo presidente republicano prometeu em primeiro lugar se afastar dos projetos de "construção da paz" e de "nação" que foram a marca da política clintoniana nos conflitos de Somália, Haiti, Bósnia, Kosovo e IsraelPalestina, associando-se a um internacionalismo doravante abandonado. Havia um tom mais nacionalista, com ecos isolacionistas. Um ano depois, $e$ para a surpresa de muitos, Bush abraçava um engajamento com o mundo externo muito mais intenso do que Clinton e iniciava o mais abrangente processo de "construção de nação" desde a democratização introduzida na Alemanha e no Japão após a Segunda Guerra Mundial. (2007, p.196)
\end{abstract}

Tal mudança na política de Bush se deu, em grande parte, devido aos atentados de 11 de setembro, quando quatro aviões foram sequestrados e atirados contra alvos estratégicos dos EUA. Dois deles colidiram contra as Torres Gêmeas do World Trade Center, em Nova York. Esse incidente foi transmitido em tempo real para diversos locais do mundo, os telespectadores acompanharam cada colisão e, na sequência, as torres vieram abaixo, levantando uma enorme nuvem de poeira. O World Trade Center não foi o único local atingido em 11 de setembro, um terceiro avião colidiu contra o Pentágono e o quarto caiu em uma região pouco habitada da Pensilvânia (acredita-se que este teria como possível alvo a Casa Branca, entretanto, foi derrubado antes de chegar lá). Voltaremos a analisar o governo Bush e as consequências do 11 de setembro em suas políticas mais adiante, agora, vamos nos ater aos danos sociais e ao "trauma coletivo" que os ataques desencadearam.

\title{
1.2 Tragédia, medo, raiva, insegurança e vergonha
}

Os ataques de 11 de setembro de 2001 resultaram na morte de, aproximadamente, 5 mil cidadãos norte-americanos (somando-se as vítimas no World Trade Center, no Pentágono, na Pensilvânia e outras pessoas que morreram devido a algum dano colateral da queda das torres). A autoria desse fatídico acontecimento foi atribuída à rede internacional de

\footnotetext{
25 "No U.S. troops should be in harm's way unless America's interests are at stake, no U.S. troops will ever serve under UN command." (BUSH, 2000).
} 
terrorismo, Al-Qaeda, liderada por Osama bin Laden. A reação quase imediata do governo norte-americano foi a declaração da chamada "Guerra ao Terror". Isto resultou na invasão do Afeganistão, país governado pelo grupo islâmico Talibã que, de acordo com os serviços de inteligência dos EUA, estava dando apoio - e servindo como base de operações para - a $A l$ Qaeda.

Strobe Talbott e Nayan Chanda, na introdução de sua coletânea de artigos sobre o 11 de setembro, chamam a atenção para o extenso número de vítimas que os atentados provocaram e destacam como esse fato não possui precedentes na história dos Estados Unidos. De acordo com os autores,

O 11 de setembro resultou em um número de americanos mortos quase cinco vezes maior que o de todos os incidentes terroristas das três décadas anteriores somados. A carnificina foi quase trinta vezes maior que a infligida por Timothy McVeigh, um louco local, na cidade de Oklahoma em 1995, e cerca de duas vezes maior que a provocada por trezentos bombardeiros japoneses em Pearl Harbor. Os comentaristas imediatamente evocaram aquele outro ataque relâmpago, de sessenta anos antes, como o que havia de mais próximo em termos de precedente. Na verdade, porém, não havia precedente algum. $O$ que acontecera era algo novo sob o sol. (TALBOTT e CHANDA, 2002, p.10)

Além das mortes e dos estragos sem precedentes, os atentados de 11 de setembro também abalaram a segurança dos EUA, ou melhor, a concepção que os norte-americanos tinham sobre sua intransponível segurança geográfica. Devido a uma ausência de ataques em seu território, mesmo em períodos de guerra como na Segunda Guerra e durante a Guerra Fria, os atentados de 11 de setembro geraram um grande sentimento de insegurança. Havia um grande clima de medo, pois não se sabia quando e se ocorreria outro ataque desse tipo. $\mathrm{O}$ historiador John Lewis Gaddis (2002) argumenta que os atentados fizeram com que os cidadãos norte-americanos mudassem sua ideia de segurança nacional; durante muito tempo acreditou-se que as ameaças aos Estados Unidos estavam fora do país, porém

Após o 11 de setembro, não somente adotamos o conceito de "segurança interna" como ele tornou-se sinônimo de segurança nacional - tal é a revolução impingida às nossas ideias pelos eventos daquele dia. Assim, os americanos ingressaram em uma nova fase de sua história, na qual já não podem mais dar a sua segurança como certa: ela deixou de ser gratuitaem todos os lugares e momentos. (GADDIS, p.26, 2002)

Esse sentimento de insegurança veio acompanhado de um forte e não explicito sentimento de "vergonha". Para Susan Faludi (2007), os atentados de 11 de setembro provocaram mais do que um trauma, eles expuseram os Estados Unidos, seu povo e seu 
governo, principalmente, a uma vergonhosa situação, pois todos haviam falhado em proteger seu país, ninguém pode prever ou evitar os atentados. Ela afirma que

As intrusões de 11 de setembro quebraram o ferrolho de nosso mito de proteção, a ilusão de que somos mestres de nossa segurança, que nosso poder faz com que nossa pátria seja inexpugnável, que nossas famílias estão seguras no caramanchão de suas comunidades e que nossas mulheres e crianças estão seguras nos braços de seus homens. Os eventos daquela manhã nos disseram que não podemos mais depender de nossos protetores: a Casa Branca não agiu para impedir um ataque iminente, a Administração de Aviação Federal não tornou seguro nossos aeroportos e aviões, os militares não garantiram a segurança de nossos céus, os operadores do 911 não emitiram os avisos necessários, as equipes de resgate da cidade, não por culpa própria, não podiam retirar seus concidadãos do perigo - em suma, todo o edifício de segurança norte-americano falhou em fornecer um escudo. Em todos os pesadelos díspares de homens e mulheres depois de 11/09, o que acompanhou a quebra de nossa fé em nossa invencibilidade não era apenas raiva, mas o choque dessa revelação, e com o choque, medo, desonra e vergonha. (FALUDI, 2007, p.12 tradução nossa) ${ }^{26}$

Os sentimentos citados, acima, caracterizam o que Arthur G. Neal chama de "trauma nacional", que pode ser entendido como uma ampliação para o coletivo do conceito de "trauma" utilizado para definir como determinados eventos chocantes afetam a vida pessoal de determinados indivíduos. De acordo com Neal, um "trauma nacional” se configura quando "alguma coisa terrível, deplorável, ou anormal ocorre, e a vida social perde sua previsibilidade.” (2005, p.04, tradução nossa ${ }^{27}$. As reações iniciais da população a um trauma nacional, como os ataques de 11 de setembro, apresentam, em sua maioria, um forte sentimento de "descrença" e "incredulidade". As pessoas não acreditam naquilo ou se recusam a entender o que aconteceu. Além disso, elas "se tornam indecisas sobre no que elas devem ou não acreditar." (Ibidem). As reações imediatas da população podem variar muito, entretanto, elas frequentemente "[...] envolvem elementos de medo e um senso de vulnerabilidade. ${ }^{\text {(Ibidem) }}{ }^{28}$

\footnotetext{
26 "The intrusions of September 11 broke the dead bolt on our protective myth, the illusion that we are masters of our security, that our might makes our homeland impregnable, that our families are safe in the bower of their communities and our women and children safe in the arms of their men. The events of that morning told us that we could not depend on our protectors: that the White House had not acted on warnings of an impending attack, that the Federal Aviation Administration had not made safe our airports and planes, that the military had not secured our skies, that the 911 dispatchers had not issued the necessary warnings, and that the city's rescue workers, through no fault of their own, could not pluck their fellow citizens from danger-in short, that the entire edifice of American security had failed to provide a shield. In all the disparate nightmares of men and women after $9 / 11$, what accompanied the sundering of our faith in our own indomitability was not just rage but shock at that revelation, and, with the shock, fear, ignominy, and shame." (FALUDI, 2007, p.12).

27 "Something terrible, deplorable, or abnormal has happened, and social life has lost its predictability." (NEAL, 2005, p.04)

${ }^{28}$ Os trechos originais do livro de Neal são os seguintes: "[...] and people become uncertain about what they should or ought to believe."; "Responses to national trauma involve elements of fear and a sense o vulnerability" (2005, p.04).
} 
Essas sensações evocam um "imaginário de estar vivendo em um mundo perigoso que não corresponde às necessidades e interesses pessoais.” (NEAL, 2005, p.05, tradução nossa), criando um clima de fragilidade e tristeza generalizado, e quando essa "tristeza coletiva é acompanhada pela raiva, frequentemente desenvolve-se uma situação volátil." (Ibidem). ${ }^{29}$ Isso afeta a vida de toda a população de diferentes maneiras e também seus sistemas sociais. Nas palavras de Arthur G. Neal,

Um trauma nacional envolve danos suficientes ao sistema social que o discurso nacional é todo direcionado para os trabalhos de reparos que devem ser realizados. A integridade da ordem social foi posta em questão, $e$ os valores compartilhados estão ameaçados. A ruptura pode tomar a forma de uma ameaça de invasão estrangeira, [...] ou o surgimento de conflitos rancorosos sobre valores, práticas e prioridades. Qualquer que seja sua forma, o trauma apresenta um significante e deplorável afastamento da normalidade cotidiana da vida em progresso. (Ibidem) ${ }^{30}$

Assim, uma das principais tarefas que o governo dos Estados Unidos tinha pela frente era como reestabelecer essa "normalidade" nas vidas de seus cidadãos. E também precisava achar uma maneira de provar que seu país ainda era um local seguro, os EUA até então eram uma nação poderosa e os atos cometidos não ficariam impunes. Com sua fraqueza exposta para o mundo todo, os Estados Unidos queriam reafirmar sua supremacia perante as outras nações. Determinar os responsáveis pelo ocorrido e iniciar uma guerra contra o que foi designado como terrorismo internacional pode ser entendido como uma primeira resposta aos danos causados. Entretanto, para resolver todos os traumas, não basta uma demonstração de força, é necessário também um momento de autorreflexão, as ações passadas e futuras dos Estados Unidos deveriam passar por uma reavaliação para se determinar a melhor maneira de se superar aquele quadro.

A exposição indesejada de suas fraquezas deveria fazer com que os estadunidenses reavaliassem seu papel no mundo. Para o jornalista norte-americano, Mark Hertsgaard, até o dia dos atentados, a visão que grande parte da população dos Estados Unidos tinha de si mesma era a de que constituíam uma nação de "pessoas decentes, que trabalham duro, desejam o bem para o resto do mundo e fazem mais do que sua obrigação para ajudá-lo.

\footnotetext{
${ }^{29} \mathrm{O}$ original dos dois trechos citados é o seguinte: "Thus, national trauma evokes a imaginary of living in a dangerous world that is unresponsive to personal needs and interests." "When collective sadness is accompanied by anger, a volatile situation frequently develops." (NEAL, 2005, p.05).

30 "A national trauma involves sufficient damage to the social system that discourse throughout the nation is directed toward the repair work that needs to be done. The integrity of the social order has been called into question, and shared values are threatened. The disruption may take the form of a threat of foreign invasion, a collapse of the economic system, a technological catastrophe, or the emergence of rancorous conflicts over values, practices, and priorities. Whatever form the trauma takes, a significant and deplorable departure from the normality of every day life is in process." (Ibidem, p.05-06).
} 
[Que têm] orgulho de sua liberdade [e de seu] modo próspero de vida”. (HERTSGAARD, 2003, p.14). Para o autor, o 11 de setembro colocou essas crenças em dúvida e levantou as seguintes questões: se os EUA são tão bons para o resto do mundo, por que eles foram atacados dessa maneira? Por que pessoas em outros países chegaram a comemorar os atentados contra os EUA? E a grande questão exposta pela mídia norte-americana: "por que eles nos odeiam?" Ou o que os Estados Unidos fizeram para despertar o ódio de outros povos?

Hertsgaard acredita que o 11 de setembro "nos obriga a olhar nossa pátria com olhos novos - em particular, com os olhos do resto do mundo.” (2003, p.15). Contudo, isto não ocorreu de imediato, "a reação inicial, talvez inevitável, foi militar", um exemplo evidente do "ditado de um caubói de Hollywood: 'atirar primeiro, perguntar depois.", (HERTSGAARD, 2003, p.22).

Com o início da "Operation Enduring Freedom" [Operação Liberdade Duradoura] em 7 de outubro de 2001, no Afeganistão, as reflexões mais profundas foram deixadas para um segundo momento. Entretanto, mesmo durante esse período de "atirar", houve diversas vozes que se opuseram à guerra e procuraram estabelecer críticas quanto à real necessidade de invadir e dominar um pequeno e pobre país do Oriente Médio, sob o pretexto de vingar as vítimas dos atentados. O trabalho de Mark Hertsgaard constitui uma dessas vozes, o autor procura estabelecer uma nova interpretação dos Estados Unidos e de seu papel mundial por meio da análise de depoimentos de pessoas de outros países. Outra obra que tentou expor uma visão mais crítica com relação a esse momento traumático dos Estados Unidos é nosso corpo de fontes, as histórias em quadrinhos do Capitão América.

\subsection{Criando um "novo" Capitão América}

Estabelecer uma interpretação crítica dos Estados Unidos pós-11 de setembro também é a preocupação do roteirista John Ney Rieber e do desenhista John Cassaday ${ }^{31}$ que, entre junho e dezembro de $2002^{32}$, produziram para a Marvel Comics uma "nova" série das histórias em quadrinhos do Capitão América.

\footnotetext{
31 As histórias em quadrinhos norte-americanas têm sua produção subdividida, como em uma linha de montagem, além de Rieber e Cassaday, a revista contou com o trabalho de: Dave Stewart (colorização), Richard Starking e Comicraft's Wes Abbot (letras); os editores dessas revistas foram Stuart Moore e Joe Quesada. Para facilitar faremos referência apenas ao nome do roteirista e do desenhista.

${ }^{32}$ No Brasil, essa série foi publicada nas revistas "Marvel 2002" edições 9, 10, 11 e 12; e nas edições 3 e 4 da revista "Marvel 2003", lançadas pela editora Panini entre setembro e dezembro de 2002; e março e abril de 2003.
} 
Rieber é um roteirista de histórias em quadrinhos que já escreveu para diversas editoras desse ramo nos Estados Unidos. Seu trabalho de maior projeção é a série "The Books of Magic" [Livros da Magia] ${ }^{33}$ para a DC comics, escreveu ainda roteiros para as versões em quadrinhos do vídeo game Tomb Raider e algumas edições dos G.I. Joe. Rieber é um escritor reservado no comportamento, não existem muitas informações pessoais sobre ele disponíveis nos meios digitais, ele também não concede tantas entrevistas a publicações especializadas em quadrinhos, porém, na edição de fevereiro de 2002 do The Comic Journal, foi publicada uma longa entrevista com Rieber, feita em três momentos distintos, o último data de $1^{\circ}$ de dezembro de 2001 e o autor responde a uma série de questões sobre seu trabalho com o Capitão América e o 11 de setembro. Ele foi contratado pela Marvel Comics para desenvolver um Capitão América que seria “alguém vive na mesma América que o resto de nós realmente vive. E eles queriam uma obra sobre inquietações contemporâneas [...]” (RIEBER, 2002, p.87, tradução nossa). ${ }^{34}$

O desenhista John Cassaday possui uma lista extensa de trabalhos para várias editoras de quadrinhos norte-americanas, entre os mais conhecidos está a série Planetary ${ }^{35}$ e o período em que desenhou as HQs dos $X-M_{e n}{ }^{36}$. Cassaday tem cerca de 43 anos, mora em Nova York; no dia 11 de setembro, testemunhou toda a destruição causada pelos atentados e sua reação foi a seguinte:

Eu só podia ficar com raiva. Eu fiquei no cais por mais de uma hora. Muitos de nós se reuniram em torno de rádios para chegar as ultimas noticias. Parecia que estávamos na década de 1940. Eu, finalmente, caminhei para casa, fui para a Cruz Vermelha, e depois fiquei vagando pelo local. Cheguei em casa por volta da meia-noite. (CASSADAY, 2001, tradução nossa) ${ }^{37}$

Cassaday sentiu-se extremamente arrasado com o ocorrido e, após os atentados, para ele, os quadrinhos de super-heróis se tornaram triviais. Por isso, ele e Rieber queriam fazer

\footnotetext{
${ }^{33}$ Essa série conta a história de Tim Hunter um adolescente que vai descobrindo e desenvolvendo seus dons mágicos; a série foi criada 1990 pelo escritor Neil Gaiman e foi escrita por Rieber até a edição 50.

34 "to be someone who lived in the same America that the rest of us really live in. And they wanted the book to be about contemporary concerns [...]" RIEBER, John Ney. In: The Comics Journal, 241, fevereiro de 2002.

${ }^{35}$ Planetary é uma série de quadrinhos desenvolvida pelo escritor Warren Ellis e teve 27 edições desenhadas por Cassaday. De forma resumida a HQ conta as aventuras de uma equipe de heróis que investigam e protegem fatos incomuns que ocorrem no mundo.

${ }^{36}$ Os X-Men são um grupo de super-heróis com poderes provenientes de mutações genéticas, eles lutam para serem aceitos pelos seres humanos "normais" e combatem supervilões mutantes ou não que tentam atrapalhar os sonhos de convivência pacífica idealizados pelo mentor do grupo, o professor Charles Xavier. O grupo foi criado em 1963, por Stan Lee e Jack Kirby, e como o Capitão América já passou por diversas equipes criativas, Cassaday desenhou as HQs entre 2004 e 2005, com os roteiros de Joss Whedon.

37 "I could only get angry. I stayed on the pier for over an hour. Many of us were huddled around radios to get the latest. It felt like we were in the 1940's. I finally walked home, went to the Red Cross, then wandered down to the site. I got home around midnight." CASSADAY, John. In: Comic Book Resurce, outubro de 2001. Disponível em: <http://www.comicbookresources.com/?page=article\&id=540 >Acesso em: 23/01/2014.
} 
um Capitão América que tivesse alguma "[...] relevância em nosso mundo atual.” (Ibidem). ${ }^{38}$ Os autores tiveram um amplo apoio de seus editores e produziram essa série do Capitão América para o selo Marvel Knights, que tinha como proposta "publicações mais "adultas" e mais "realistas" com os tradicionais personagens da editora." (SOUZA, 2003). Rieber afirma que ao escrever seus roteiros para essa nova série do personagem, ele pensou em produzir algo que pudesse ser lido por jovens na faixa de treze a dezessete anos ${ }^{39}$, que é a faixa etária recomendada pelo selo Marvel Knights. Ele afirma que não the foi imposto nenhum tipo de censura, "Você não precisa censurá-lo para adequar-se as diretrizes. Isto não é, de fato, um problema, eu não preciso suavizar ou diluir coisa alguma." (RIEBER, 2002, p.90, tradução nossa) ${ }^{40}$. Quando questionado sobre quais eram essas diretrizes, Rieber disse que não havia nenhuma especifica, ele apenas se preocupou em manter as características que o personagem desenvolveu ao longo do tempo e, a seguir, os conselhos de seu editor.

Assim, percebe-se que o foco dos autores foi mostrar sua visão de realidade, queriam conectar o Capitão América com o mundo real; sobre isso, Cassaday disse que:

Eu amo os personagens com os quais trabalharei no futuro, mas eu acho que eles podem viver em um mundo mais realista. Não um com supervilões fantasiados saindo de discos voadores para destruir a raça humana e os seus cachorrinhos também. Há ameaças reais do mundo, como temos visto, e eu acho que o que eu vou fazer no futuro imediato terá que lidar especificamente com isso. (2001, tradução nossa) ${ }^{41}$

Rieber afirma que o que eles se propuseram a fazer com o Capitão América talvez não fosse o que as pessoas esperassem de um

personagem que nasceu quando a guerra estava em primeiro plano - um super-soldado, é como muitos chamam ele. A parte mais dificil de escrever essas edições é saber o que de fato as pessoas querem e o que realmente

\footnotetext{
38 “[...] it must have relevance in our world right now." CASSADAY, John. In: Comic Book Resource, outubro de 2001. Disponível em: http://www.comicbookresources.com/?page=article\&id=540 Acesso em: 23/01/ 2014.

${ }^{39}$ Não conseguimos ter acesso a dados mais precisos sobre o público leitor dessa série, temos, somente, essa vaga noção de faixa etária indicada. Entretanto, o público leitor de HQs costuma ser majoritariamente masculino e, de acordo com uma pesquisa realizada no final de 2013 pela Brett Schenker, através da rede social Facebook, aproximadamente, $40 \%$ dos leitores de quadrinhos são mulheres contra, aproximadamente, 58\% de homens (os outros $2 \%$ não definiram o sexo); a pesquisa também mostra que a faixa etária da maioria desses leitores masculinos é formada por jovens entre 18 e 21 anos (61.54\%). A pesquisa indica que existe um grande número de leitores na faixa de 30 a 64 anos de idade, evidenciando que, apesar de serem feitas para um público mais jovem, as HQs não se limitam a esse público. Pesquisa disponível em:<http://comicsbeat.com/facebook-stats-40of-comics-fans-are-women/ >Acesso em: 02/02/ 2013.

40 "You don't need to censor him to meet the guidelines. It's not really a problem, I don't need to soften anything or dilute anything.” RIEBER, John Ney. In: The Comics Journal, 241, fevereiro de 2002.

41 "I love the characters I'm gonna be working on in the future, but I think they can live in a more realistic world. Not one with costumed supervillains dropping out of flying saucers to destroy the human race and their little dogs too. There are very real threats in the world, as we've seen, and I think what I'm gonna be doing in the immediate future will have to deal specifically with that." CASSADAY, John. In: Comic Book Resources, outubro de 2001. Disponível em: <http://www.comicbookresources.com/?page=article\&id=540> Acesso em: 23/01/ 2014.
} 
elas esperam do Capitão nesses tempos, se querem ver o Capitão chutando a bunda dos terroristas na primeira edição. E não é sobre isso que escrevo. Eu gosto muito da história que escrevi, isto é o que eu - eu fiz o que eu queria fazer. Mas eu não tenho ideia como isso vai ser recebido quando for lançado.(RIEBER, 2002, p.88, tradução nossa) ${ }^{42}$

Outra preocupação que Rieber teve ao desenvolver os roteiros destas HQs foi com o passado do herói. Ele leu várias edições antigas do personagem e tentou estabelecer uma síntese dos ideais pelos quais o super-herói lutara. Para Rieber o Capitão América representa

[...] o "melhor da América", o sonho, o espírito - uma parte disso é a maneira que lutamos com as coisas. Há uma grande tradição Americana em termos esses tipos de compromissos icônicos com a liberdade, justiça e o fato de que temos direitos inalienáveis porque somos seres humanos. E lutamos para entender o que isso significa e como vamos implementar isso. (RIEBER, 2002, p.89, tradução nossa) ${ }^{43}$

Partindo dessa declaração, podemos entender que, para ele, o Capitão América é um símbolo de valores culturais e políticos dos Estados Unidos. Isto ocorre desde o momento em que o personagem foi criado em 1941 por Jack Kirby e Joe Simon, durante a Segunda Guerra Mundial. O Capitão foi encomendado pela editora Timely Comics (posteriormente, essa editora tornou-se a Marvel Comics) que queria um herói patriótico para combater a ameaça nazifascista, representando, defendendo e divulgando os ideais e as políticas norte-americanas predominantes no período. O geógrafo Jason Dittmer afirma que o Capitão América, ao ser caracterizado "como um super-herói explicitamente americano ele se estabeleceu ao mesmo tempo como um representativo de uma nação Americana idealizada e como um defensor do status quo americano." (2005, p.627, tradução nossa $)^{44}$.

Entretanto, ao longo de sua existência (mais de 70 anos), o personagem passou por diversas equipes criativas que introduziram consecutivas adaptações para mantê-lo atualizado, consumível e com algum significado para diversas gerações de leitores. Isto o transformou em um "personagem que é familiar a diversas gerações de americanos." (DITTMER, 2005, p.628, tradução nossa) ${ }^{45}$. Isto fez do Capitão América um personagem relativamente

\footnotetext{
42 " [....] this are a character who was born of a war in the first place - a super-soldier, that's one of the things they call him. The hardest part of writing this issue was knowing that people would really really want and expect, in these times, is for Cap to be kicking some terrorist ass in the first issue. And that's not it's about. I like the story a lot, it does what I - it does what I wanted to do. But I have no idea how it's going to be received when it does come out." RIEBER, John Ney. In: The Comics Journal, 241, fevereiro de 2002.

43 ' [...] the character representing the 'the best of America', the dream, the spirit - part of that is the way we wrestle with things. There's a great tradition of having that kind o iconic commitment to liberty, justice, freedom and the fact that we have inalienable rights because we're human. And struggling with understanding what means and how do we implement that." RIEBER, John Ney. In: The Comics Journal, 241, fevereiro de 2002.

44 "[...] as an explicitly American superhero establishes him as both a representative of the idealized American nation and as a defender of the American status quo.” (DITTMER, 2005, p. 627).

45 " [...] Captain America is a character that is familiar to several generations of Americans." (Ibidem, p.628).
} 
inconstante, apresentando diversas fases, variando de acordo com as ideias dos artistas que produziram suas HQs e com o período no qual foram feitas. Mesmo assim, em suas diversas versões, o Capitão

[...] muitas vezes pensa criticamente sobre os fatos da história de seu tempo, sobre a legitimidade de comandos superiores e como suas ações são vistas pelos outros. Seu comportamento, portanto, carrega as marcas da política e das políticas do momento. (LAWRENCE, 2009, p.01, tradução nossa) ${ }^{46}$

Essas interpretações do personagem e sua permanência no imaginário político e cultural dos Estados Unidos conferiam ao Capitão América uma característica de símbolo nacional que poucos super-heróis de HQs têm. Guardadas as proporções, ele pode ser comparado a outros símbolos nacionais, como o Tio Sam (Uncle Sam), a Águia Careca e a própria bandeira nacional, que o personagem usa como vestimenta, porém, o Capitão América, apresenta significativas diferenças e vantagens, se comparado com esses símbolos

[...] por causa de sua habilidade de, ao mesmo tempo, incorporar e narrar a América de uma maneira que a Águia Careca, a bandeira e outros símbolos não têm. Desta maneira, esses símbolos estáticos e não humanos representam e constroem a nação, mas não permitem uma conexão pessoal como a que o Capitão América permite. [...] O Capitão América serve como um produto cultural que vagamente e invisivelmente conecta o leitor (comumente jovens do sexo masculino, aspirando ao heroísmo), através do corpo do herói, até a escala da nação. Essa ponte de escala, do corpo individual para o corpo político, é necessária para a construção de um estado territorialmente delimitado, ocupado por uma nação coesa. (DITTMER, 2005, p.630, tradução nossa, grifos no original) ${ }^{47}$

Além disso, por caracterizar uma "narrativa heroica", os quadrinhos do Capitão América também “[...] fornecem uma avenida na qual qualquer um pode ter acesso aos valores fundamentais de uma sociedade, os ideais que dão a essa sociedade uma identidade, e o "outro" que essa sociedade teme." (COSTELLO, 2009, p.15, tradução nossa) ${ }^{48}$. Assim, pode-se dizer que, por ser um símbolo nacional com um maior dinamismo, se comparado a

\footnotetext{
46 " [...] Cap often thinks critically about the facts of history in his time, the legitimacy of commands from superiors, and how his actions are seen by others. His behavior thus bears the marks of politics and policies of the moment. (LAWRENCE, 2009, p.01).

47 "As just illustrated, the impact of Captain America on readers is different than other symbols of America, such as the bald eagle or the flag because of his ability both to embody and to narrate America in ways that the bald eagle, flag, and other symbols cannot. Such static, nonhuman symbols represent and construct the nation but do not allow for a personal connection to it in the same way that Captain America does. [...] Captain America serves as a cultural product that vaguely and invisibly connects the reader (usually young and male, aspiring to heroism), through the body of the hero, to the scale of the nation. This bridging of scale, from the individual body to the body politic, is necessary for the construction of a territorially bounded state occupied by a cohesive nation." (DITTMER, 2005, p. 630).

48 " [...] the heroic narrative offers an avenue through which one can access the core values of a society, the ideals that gives that society an identity, and the "other" that society fears." (COSTELLO, 2009, p.15).
} 
outros personagens similares, o Capitão América e suas HQs contribuem para a discussão de questões relacionadas com a identidade nacional dos Estados Unidos.

Em sua reelaboração do Capitão América, Rieber e Cassaday colocaram-no em situações de interagir com o trauma e os sentimentos de insegurança dos cidadãos dos Estados Unidos e, ao fazer isso, eles estabeleceram uma discussão sobre a identidade nacional, após os atentados de 11 de setembro, porém esta nova configuração apresenta particularidades que merecem uma análise mais aprofundada.

Nesta primeira parte, analisaremos como os autores reconfiguraram o personagem para lidar com os traumas causados pelos atentados de 11 de setembro e quais críticas eles fizeram às políticas e ao governo de George W. Bush e à Guerra ao Terror.

Antes de iniciar a análise das HQs, faz-se necessário uma breve descrição técnica dessa nova série do personagem. Ela é composta por seis edições (Figura 1.), os textos são, em sua maioria, compostos pelos pensamentos do personagem, há poucos diálogos e a maioria deles constituem debates entre o Capitão e outros personagens. De forma resumida, o roteiro delas é o seguinte:

Nas três primeiras edições, os autores narram como ocorreram os atentados e mostram Steve Rogers (alter ego do Capitão América) extremamente empenhado em resgatar algum sobrevivente em meio aos escombros. O Capitão é convocado pelo Coronel Nick Fury para ir lutar no Afeganistão, mas ele se recusa. Depois, quando deixa o Marco Zero ${ }^{49}$, o Capitão salva um jovem árabe-americano de ser agredido por um homem que perdeu a filha nos atentados. Posteriormente, ainda na primeira edição, o Capitão é chamado a resolver uma situação fictícia de ataque terrorista a uma pequena cidade do interior chamada Centerville. Ele derrota todos os inimigos e tem uma luta mortal contra o líder dos terroristas, chamado Faysal Al-Tariq. O herói descobre que seus inimigos usam um dispositivo eletrônico chamado de $\operatorname{CATtags}^{50}$, o qual deveria ser de uso exclusivo das forças armadas norte-americanas.

As três últimas edições da série mostram o Capitão América em busca de algumas explicações de seus superiores sobre os CATtags. Para encontrar suas respostas, o personagem viaja para Dresden, na Alemanha, local onde os dispositivos são fabricados. Entretanto, tudo não passa de um plano para destruir o Capitão América, arquitetado pelo autointitulado

\footnotetext{
${ }^{49}$ Marco Zero é o nome dado ao local onde se localizavam as torres do World Trade Center, e onde foi construído um memorial em homenagem às vítimas.

${ }^{50}$ CAT: Casualty Awareness Tracking, a palavra tag, em inglês, tem o significado de algo que se prende ao pescoço como uma coleira. Assim, o termo pode ser traduzido literalmente por "coleira de gato". Os CATtags são dispositivos eletrônicos que aparecem nas $\mathrm{HQs}$, desde a primeira edição da série, e deveriam servir para indicar quando um soldado morre em batalha, mas, na verdade, fazem parte de um plano do "mestre" dos terroristas que intencionava vender milhares desses dispositivos ao exército americano e depois usaria eles para matar todos os soldados.
} 
"Mestre dos terroristas". Os dois personagens entram em combate e trocam acusações sobre quem realmente está do lado "certo" dessa Guerra ao Terror. A HQ termina com a vitória do Capitão América.
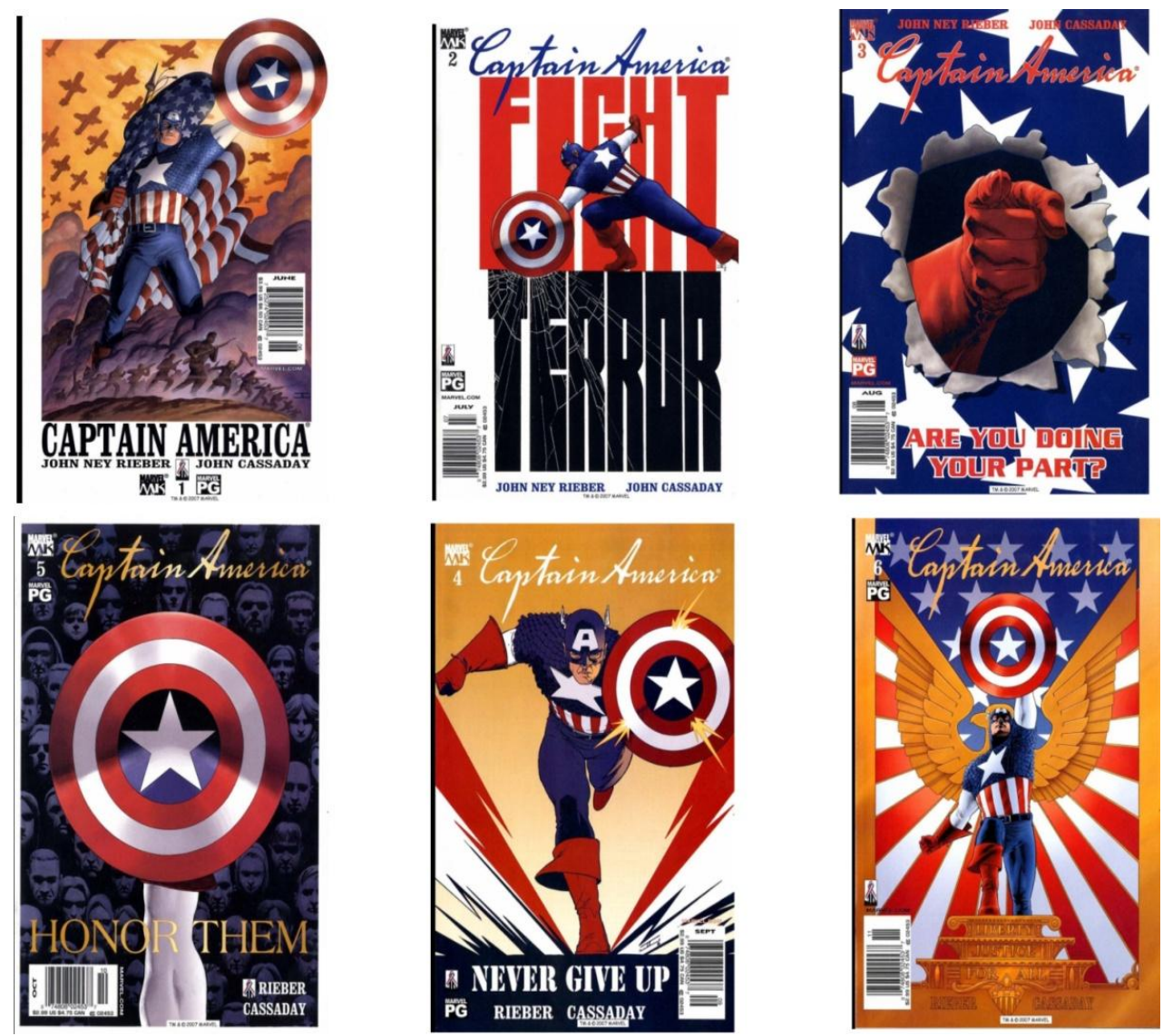

Figura 1. Capas das seis edições da série, todas foram desenhas por John Cassaday.

\subsection{0 "novo" Capitão América traz esperança a uma nação fragilizada}

O primeiro elemento a ser examinado na edição inaugural da "nova" revista em quadrinhos do Capitão América é sua capa (Figura 2.). Ela é uma adaptação de uma antiga propaganda norte-americana, da década de 1940, onde o Tio Sam (Uncle Sam) ${ }^{51}$ (outra figura simbólica dos EUA) aparece de forma triunfante, segurando a bandeira e com seu

\footnotetext{
${ }^{51}$ Uncle Sam em inglês, suas iniciais são as mesmas de United States: U.S. É um personagem fictício, baseado em uma personagem real, o comerciante de carne chamado Sam Wilson, que durante a Guerra de 1812 (guerra entre EUA e o Reino Unido que pretendia recuperar suas colônias) vendia suprimentos ao governo. Alguns soldados passaram a associar o U.S. nas caixas de suprimentos ao nome de Sam Wilson, que era chamado por todos de Uncle Sam. Assim, com o passar dos anos, a imagem do Uncle Sam se popularizou e passou a ser associada com o Exército e o Governo norte-americano. E, durante a Primeira Guerra Mundial, nos traços do artista James Montgomery Flagg, o personagem adquiriu sua caracterização mais conhecida, de um senhor com cavanhaque e cabelos brancos, vestindo um traje com as cores da bandeira e usando uma cartola. Para mais informações sobre o Tio Sam recomendamos a leitura do artigo de Ruth Miller: "Stuck or Star-struck with Uncle Sam?”. Disponível em: http://amstudies.byu.edu/static/documents/org/1185.pdf
} 
característico dedo indicador apontado para frente. Podemos observar a presença de soldados e aviões em alusão ao poder militar dos EUA. A propaganda tinha como objetivo incentivar os americanos a comprarem títulos de guerra (war bonds).
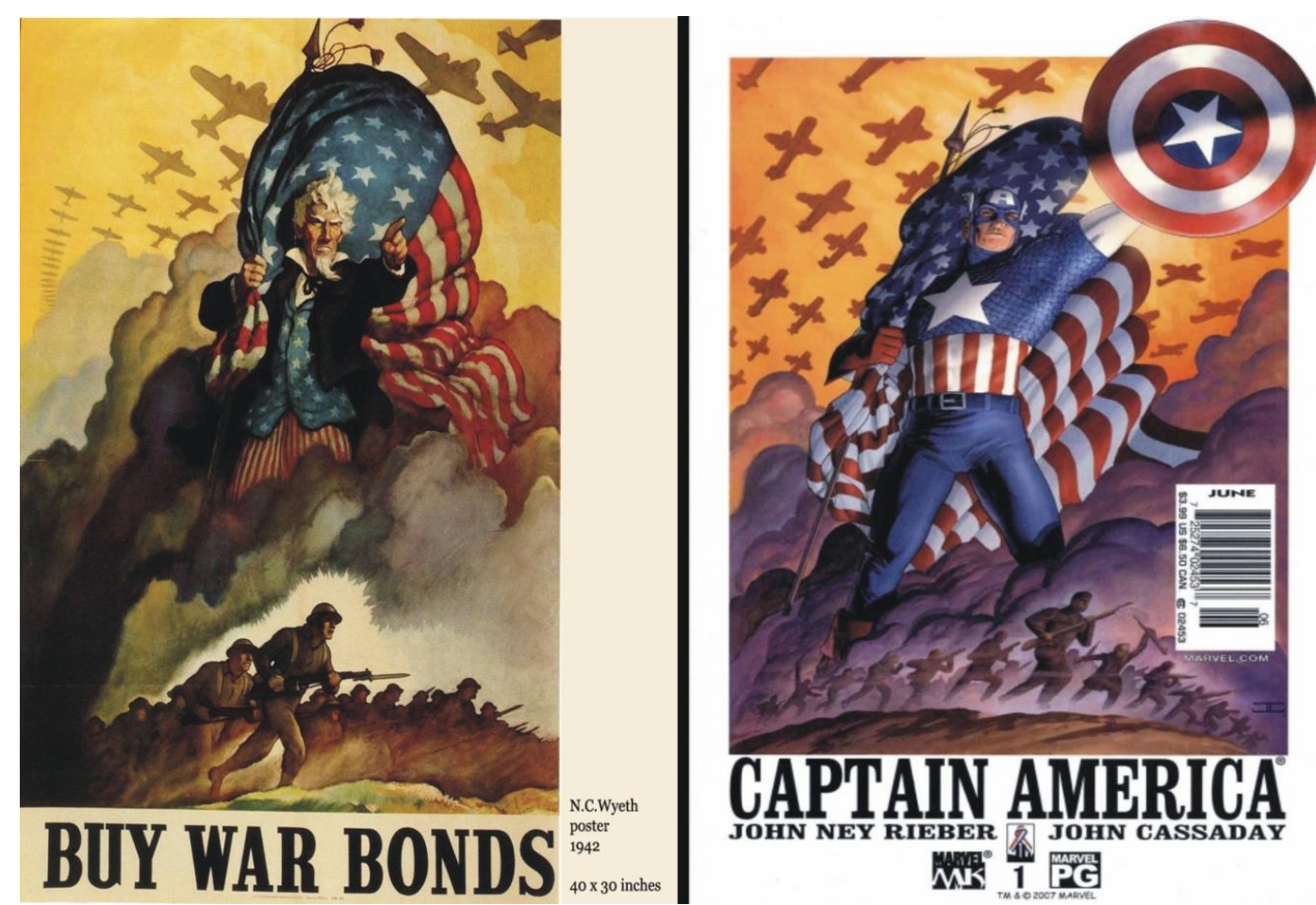

Figura 2. Tio Sam e Capitão América, dois personagens que, de diferentes maneiras, representam os Estados Unidos e seus ideais.

Essa primeira imagem que os autores nos fornecem é uma referência ao passado do personagem e dos Estados Unidos. Para Daslei Bandeira (2007), nessa referência, pode-se interpretar que os autores procuraram mostrar que o Capitão América está disposto a “defender sua nação", mensagem que a imagem do Tio Sam evocava no passado. A referida capa passa uma ideia de

confiança para o público, dando uma noção de segurança demonstrando que a nação, representada pela bandeira, seria protegida, tanto pelo Capitão, ícone mor, como pelo poderio bélico americano, os quais são autossuficientes para proteção e retaliação, já que os soldados representados estão em uma ação de ataque. (BANDEIRA, 2007, p.51)

Outra interpretação possível para essa referência à Segunda Guerra é a busca por precedentes que ajudem os Estados Unidos a terem uma noção de como devem agir nesse difícil momento de luta contra o Mal em nova configuração. O presidente George W. Bush faz isso em um discurso ao Congresso no dia 20 de setembro de 2001: 
Os americanos conheceram as guerras, mas, nos últimos 136 anos, foram guerras em solo estrangeiro, com exceção de um domingo em 1941. Os americanos conheceram as baixas de guerra, mas não no centro de uma cidade grande em uma manhã pacífica. Os americanos conheceram ataques surpresa, mas, nunca antes contra milhares de civis. ${ }^{52}$

A associação entre passado e presente, nesse caso, tem como objetivo estabelecer algum tipo de ligação entre os dois momentos. O objetivo do presidente ao estabelecer essa articulação é criar uma justificativa para que os ataques de 11 de setembro tenham a mesma resposta que o ataque à base de Pearl Harbor. No caso da capa da HQ, a ligação entre os dois momentos históricos expressa ideias diferentes das propostas pelo discurso presidencial, porém elas só são percebidas a partir da leitura do conteúdo das HQs.

A página de abertura dessa primeira edição faz uma breve referência a como os aviões foram sequestrados pelos terroristas que, segundo a versão oficial divulgada, utilizaram estiletes para renderem os tripulantes e os passageiros. Na sequência, os autores apresentam duas páginas onde vemos o que podemos considerar um grupo de pessoas (provavelmente terroristas) que comemoram ao ouvir a notícia de que os atentados deram "certo". No centro deles, aos poucos, revela-se uma figura que podemos associar a Osama bin Laden, o líder da Al-Qaeda (Figura 3.), que assumiu a responsabilidade pelo ato terrorista contra os EUA em 2001.

Nestas páginas, os autores procuraram mostrar que nem todos ficaram tristes com o ocorrido, os idealizadores dos atentados comemoram e "agradecem a Deus pelo sangue que mancha suas mãos" 53 . Além disso, como afirma Jason Dittmer (2005), "Essas páginas estabelecem uma clara dicotomia entre os que estavam dentro e o que estão fora, viajantes inocentes e desavisados em um voo doméstico, e um invasor estrangeiro distante." (p.637, tradução nossa) ${ }^{54}$.

\footnotetext{
52 "Americans have known wars, but for the past 136 years they have been wars on foreign soil, except for one Sunday in 1941. Americans have known the casualties of war, but not at the center of a great city on a peaceful morning. Americans have known surprise attacks, but never before on thousands of civilians." (tradução nossa). Discurso disponível em: <http://www.historyplace.com/speeches/gw-bush-9-11.htm> Acesso em: 26/08/2012. 53 "They praise God for the blood that stains their hands." (tradução nossa) Captain America $n^{\circ} 1$ p. 05 , jun. de 2002.

54 "These pages set up a clear dichotomy of insiders and outsiders, of innocent and un- suspecting domestic airline travelers, and of distant, foreign intruders." (DITTMER, 2005, p.637).
} 

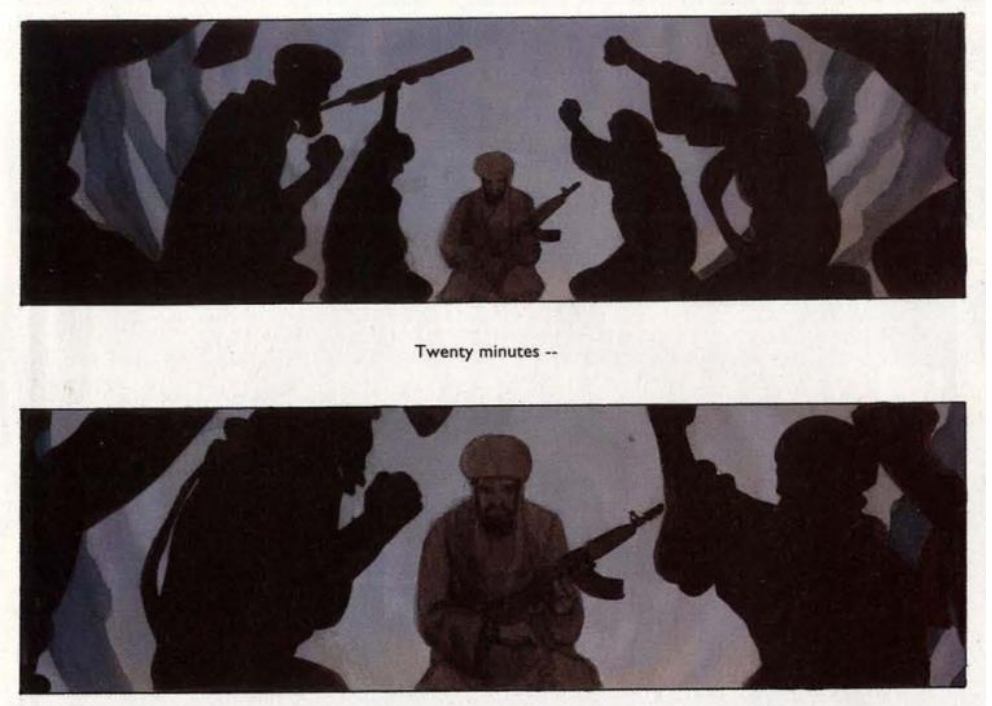

Four thousand murders later -.

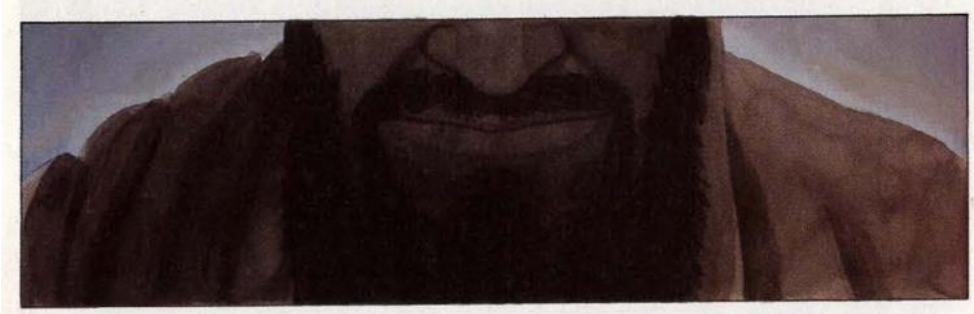

They praise God for the blood that stains their hands.

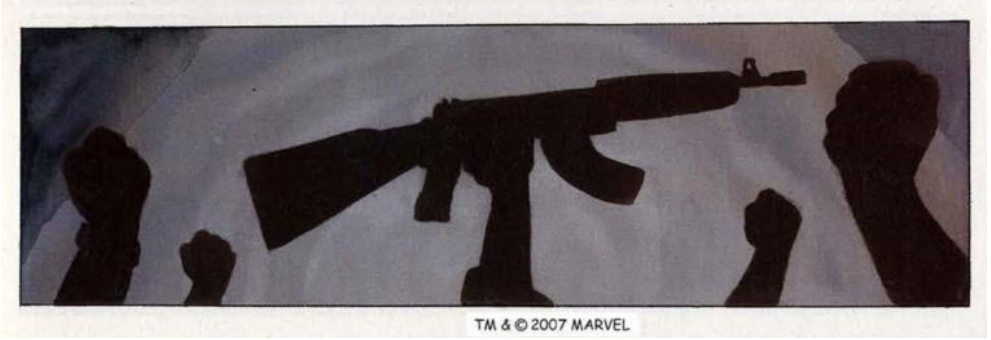

Figura 3. Terroristas e o líder deles ao centro comemoram os ataques (Captain America $\mathrm{n}^{\mathrm{o}} 1$ p.05, junho de 2002.)

Nas páginas seguintes, é apresentada uma silhueta em meio à poeira e aos escombros das Torres Gêmeas. Os quadros incluem o seguinte texto: "Oh, Deus... Como isso foi acontecer aqui? Temos que ser fortes. Mais fortes do que nunca. Se perdermos a esperança aqui... Enterrarmos nossa fé nessas trevas... Então nada mais importará. Eles terão vencido. "55 A silhueta é de Steve Rogers, o Capitão América, que está empenhando todas suas forças para tentar retirar algum sobrevivente do meio dos escombros.

A fala inicial do Capitão América demonstra o quanto ele está assustado com o ocorrido e, assim como todos em seu país, Steve Rogers não foi capaz de assimilar o que

\footnotetext{
55 "Oh, God... How could this happen here? We've got to be strong. Stronger than we've ever been. If we loose hope here... Bury our faith in this darkness... Then nothing else matters. They've won." (tradução nossa) Captain America nº 1 , p.6 e 8, jun. 2002.
} 
ocorreu e questiona Deus, evidenciando que ele e tantos outros norte-americanos tinham uma grande fé na inviolabilidade de seu território, os Estados Unidos deveriam ser um local seguro diante de tais atrocidades. Mesmo assim, pensa que as pessoas não devem perder sua fé, não podem desistir e deixar de acreditar: a esperança é a principal mensagem transmitida nessas páginas iniciais da HQ. Os autores fazem um apelo a que todos os norte-americanos "sejam mais fortes do que nunca"; por pior que seja a situação, eles não devem perder sua esperança; caso contrário, os inimigos "terão vencido".

A HQ também oferece dois pontos de vista distintos sobre a fé. Primeiramente, ela mostra que a fé dos responsáveis pelos atentados permite que eles comemorem a morte de milhares de pessoas. Já a fé do Capitão América fornece subsídios para que o sofrimento provocado pelos atentados seja superado. A fé em Deus (o Deus judaico-cristão) é uma das fontes da esperança do personagem e, consequentemente, do povo que ele representa, enquanto a fé dos terroristas (o Alá islâmico) fornece uma justificativa para seus abomináveis atos.

No decorrer da HQ evidencia-se que o Capitão América é representado com um forte sentimento de culpa. Culpa por não ter conseguido evitar os atentados e por não ter conseguido chegar a tempo para salvar algumas vidas. Enquanto procura por sobreviventes, o personagem torce para que não seja "tarde demais" e, quando uma das pessoas que trabalha com ele no resgate pergunta: "Onde você estava? Quando...”, o Capitão, com a cabeça abaixada, diz: “Eu não estava aqui." 56 (Figura 4.). Além de tristeza e culpa, a imagem transmite um sentimento de vergonha e frustração. O grande herói dos Estados Unidos não conseguiu fazer nada para evitar os atentados e pouco está conseguindo fazer para retirar alguém com vida dos escombros! A Imprensa chegou a noticiar que atores famosos por representarem personagens em filmes de ação, como Bruce Willis, ficaram muito deprimidos com o ocorrido, sentiram-se frustrados, levando em conta o que significavam seus personagens naqueles filmes.

\footnotetext{
56 "Where were you? When..." Capitão América: "I wasn’t here." (tradução nossa) Captain America no 1 p.12, jun. de 2002.
} 


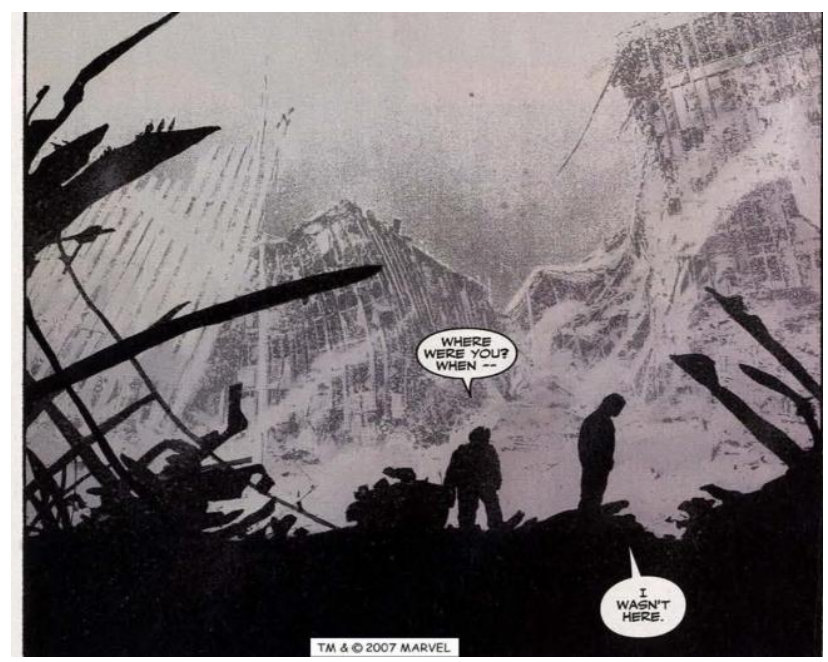

Figura 4. O Capitão América sente-se culpado por não estar próximo ao WTC na hora dos atentados e frustrado por não encontrar ninguém com vida. (Captain America $\mathrm{n}^{\circ} 1$ p.12, junho de 2002.)

Essa debilidade dos super-heróis foi um tema recorrente em outros quadrinhos desse período, como se observa numa história em quadrinhos do Homem-Aranha ${ }^{57}$, publicada em dezembro de 2001. Logo no começo, o leitor se depara com o Homem-Aranha contemplando, assustado, a destruição das Torres; na sequência, ele se aproxima do local e encontra um casal que faz uma pergunta, que foi recorrente naquele momento: "Onde vocês estavam? Como pode deixar isso acontecer? O Homem-Aranha não tem um resposta, mas pensa: "Como você diz nós não sabíamos? Tínhamos como saber. Não podíamos imaginar" ${ }^{\wedge 5}$. A HQ dá ênfase no trabalho voluntário, mostra todos os heróis e vilões unidos e trabalhando durante o resgate. $\mathrm{O}$ Homem-Aranha apresenta-se envergonhado por não poder explicar às vítimas que o indagavam como aquilo aconteceu, e questiona seu papel como herói.

Em meio a suas reflexões, ele vê o Capitão América com um semblante de tristeza e raiva contemplando a destruição, a imagem é acompanhada dos seguintes pensamentos do Homem-Aranha: "Ele é único que pode saber. Porque já esteve aqui antes. Eu desejo não ter vivido para ter visto isso. Não posso imaginar o que é ver isso pela segunda vez. Eu apenas não posso imaginar." 59 No Segundo volume da coletânea de HQs "9-11: the world's finest

\footnotetext{
${ }^{57}$ Amazing Spider-Man no 36 escrita e desenhada respectivamente por J. Michael Straczynski e John Romita Jr.. No Brasil essa história foi publicada pela editora Panini, em setembro de 2002, numa edição especial com o título: "Homem-Aranha: em memória das vítimas do 11 de setembro".

${ }^{58}$ O texto original citado é o seguinte: "Where were you? How could you let this happen?"/ How do you say we didn't know? We couldn’t know. We couldn’t image.” Spider-man n³6, p.04, dez, 2001. (tradução nossa)

59 "He's the only one who could know. Because he's been here before. I wish I had not lived to see this once. I can't imagine what is to see this twice. I just can’t imagine." Spider-man n³6, p.15, dez, 2001. (tradução nossa).
} 
comic book writers and artists teel stories to remember" 60 , o Super-Homem também apresenta suas limitações:

Eu posso desafiar as leis da gravidade. [...] Eu posso trazer um sorriso de alívio a um a população agradecida. Mas, infelizmente... tem um coisa que eu não posso fazer... eu não posso escapar destas páginas fictícias onde eu vivo e respiro... e me tornar real durante tempos de crises... e acertar as erros de um mundo injusto. Um mundo que felizmente é protegido por seus próprios heróis. ${ }^{61}$

Os trechos citados, acima, demonstram o quanto as ações desses super-heróis são limitadas quando se trata de lidar com situações reais, porém o mundo real tem "seus próprios" heróis: bombeiros, policiais, enfermeiros e voluntários que ajudaram as vítimas, esses são os verdadeiros heróis que devem ser reverenciados.

Os sentimentos de impotência e frustração apresentados por esses super-heróis, em específico pelo Capitão América, não foram algo exclusivo de tais personagens fíctícios. Eles também foram compartilhados pelos heróis de verdade - todos os bombeiros, policiais e voluntários que trabalharam no resgate de sobreviventes tiveram sua dose de frustração. De acordo com Susan Faludi (2007, p.52 e 53), pessoas de diversas localidades dos EUA se mobilizaram e foram para Nova York ajudar de alguma maneira, houve um grande número de doações de sangue e medicamentos. Entretanto, nada disso foi usado, pois "não havia ninguém para ser resgatado". Citando o depoimento de um voluntário: "Há somente partes de corpos. Fomos lá apenas para recolher partes de corpos." E “o desânimo e a humilhação induzida por essa falta de propósito, eventualmente, se instalou em todos que estavam no marco zero [...]." (FALUDI, 2007, p. 53, tradução nossa). ${ }^{62}$

Voltando ao Capitão América, mesmo desanimado e triste, ele não deixa de ter a esperança de retirar alguém com vida do meio dos escombros. Além disso, o personagem precisa saber quem causou toda aquela destruição e sofrimento. Em um diálogo posterior (Figura 5.) com seu colega de trabalho (provavelmente um voluntário), o Capitão pergunta se ele tem visto os noticiários e se já sabem quem foi o responsável pelos atentados. $\mathrm{O}$ voluntário responde: “Ah, sabem... mas, ainda o estão chamando de suspeito. Dizem que

\footnotetext{
${ }^{60}$ Produção feita em parceria entre as maiores editoras de quadrinhos dos EUA foi publicada em 2002, e seus rendimentos foram doados à agências que cuidavam das vítimas do 11 de setembro.

61 "I can defy the laws o gravity. [...] I can bring smiles to a thankful populace. But unfortunately... the one thing I can not do... is break free from the fictional pages where I live and breathe... and right the wrongs of an unjust world. A world fortunately protected by heroes of its own."(tradução nossa). Essa HQ foi escrita por Steven T. Seagle, e desenhada por Ducan Rouleau e Aaron Sowd; e se encontra nas páginas 16 e 17 da referida coletânea.

${ }^{62}$ Os trechos originais são os seguintes: “There's no rescue," [...] "It's just body parts. You're just going there to recover body parts" [...] The despondency and humiliation induced by this lack of purpose eventually settled on everyone at ground zero [...]. (FALUDI, 2007, p.53).
} 
ainda não têm evidências. Que querem ter certeza." E o Capitão diz: "Nós temos que ter certeza. Isto é guerra." ${ }^{, 63}$ Nesse diálogo, percebe-se que os autores acreditam que antes de iniciar uma guerra é necessário ter certeza de quem foi o responsável pelos ataques. Com relação a essa parte da HQ, Dittmer diz que ela apresenta duas mensagens sobre a Guerra ao Terror:

A primeira, eles estabelecem que a guerra não é uma escolha; é uma condição que foi imposta à América. [...] E a segunda coisa interessante sobre esse excerto é que, enquanto o diálogo se desenvolve, a ação é vista da perspectiva da terceira pessoa, vê-se Rogers e o voluntário cobrindo o cadáver. Nas falas finais, "Nós temos que ter certeza. Isto é guerra", nos é dada a perspectiva do cadáver, olhando para Rogers. Em uma guerra entre a América e os terroristas, não há ilusão de qual lado o leitor está. O leitor é colocado, subjetivamente, no lugar das vítimas no World Trade Center [...]. (DITTMER, 2005, p.638, tradução nossa) ${ }^{64}$
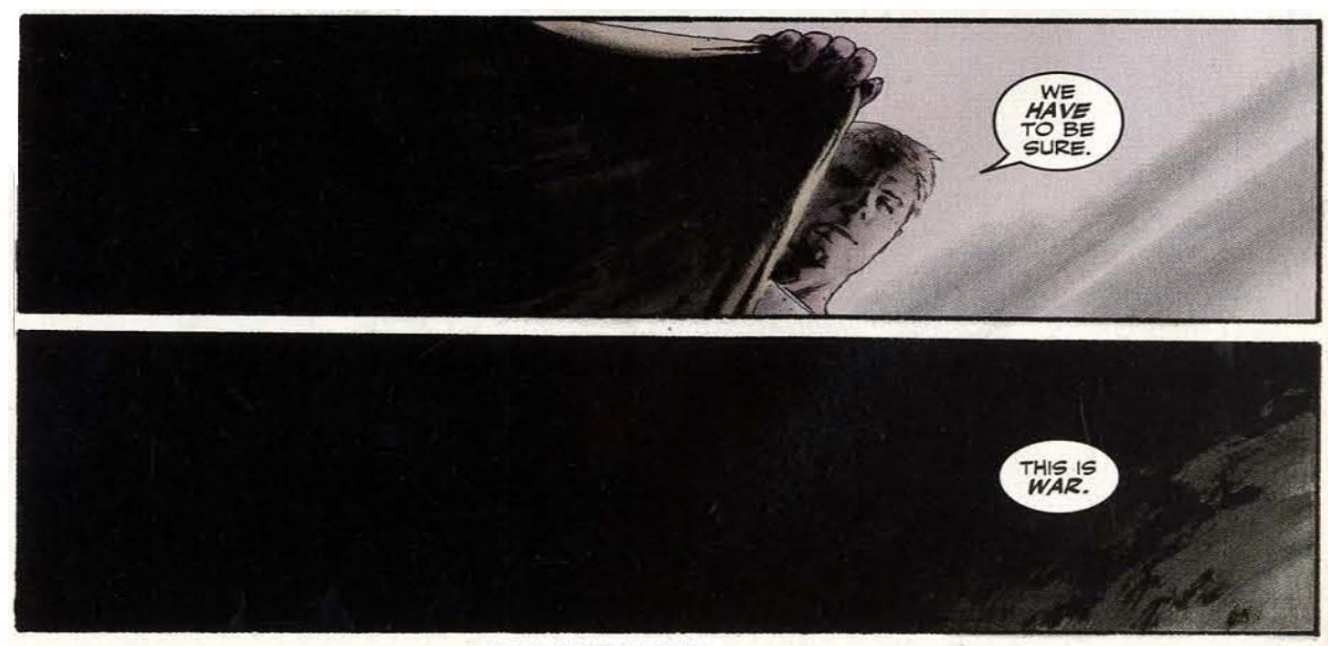

TM \& 02007 MARVEL

Figura 5. Steve Roger cobre o corpo de uma vítima e deixa claro que há uma guerra em andamento e qual é a posição do leitor nela. (Captain America $\mathrm{n}^{\circ} 1$ p.14, junho de 2002.)

Apesar de acreditar que os ataques aos Estados Unidos não podem ficar impunes, ao longo da narrativa, o Capitão América é representado com uma postura antibélica. Essa postura do personagem é expressa quando os autores introduzem um importante personagem das HQs do Capitão América: seu comandante, o Coronel Nicholas Joseph Fury, mais

\footnotetext{
${ }^{63}$ Voluntário: “Oh, they know...But they’re still calling him a suspect. They say there's no evidence yet. They say they want to be sure"./Capitão: "We have to be sure. This is war" (tradução nossa) Captain America n"1, p.14, jun. 2002.

64 "First, it establishes that war is not a choice; it is a state that America has found imposed upon it. [...] The second interesting thing about this ex-change is that while the dialogue is taking place, the action, viewed from the third person perspective, is of the rescuer and Rogers covering the corpse. The final lines, "We have to be sure. This is war," are given while the view is from the perspective of the corpse, looking up at Rogers. In a war between America and the terrorists, there is no illusion of which side the reader is on. The reader is subjectively put in the place of the victims at the World Trade Center [...]" (DITTMER, 2005, p.638).
} 
conhecido como Nick Fury ${ }^{65}$. Este vai atrás do Capitão América, pois precisa dele em Kandahar, no Afeganistão. Fury dá ordens ao Capitão, todavia, ele não o obedece, criando um momento de tensão entre eles, quando o superior hierárquico tenta impor sua autoridade e o Capitão resiste, pega o Coronel pela gola do casaco e o lança sobre um monte de entulho, dizendo (Figura 6.): "Você precisa de mim? Olhe a sua volta. Eles precisam de mim. Aqueles que podem ter apenas cinco minutos de ar ou sangue antes de morrer. "66.

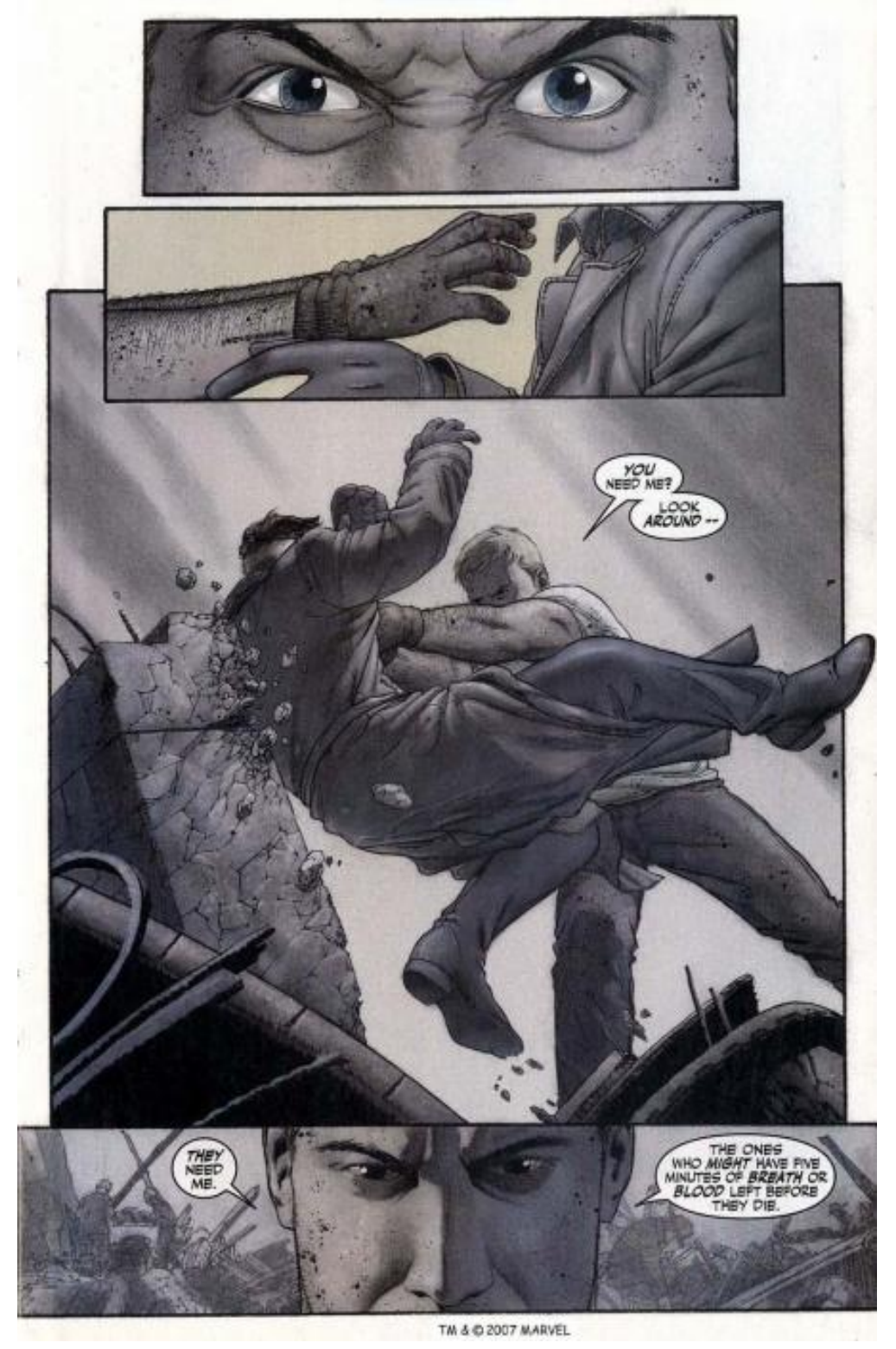

Figura 6. Desentendimento entre o herói e seu superior, as vítimas são mais importantes, nesse momento. (Captain America ${ }^{\circ} 1$ p.19, junho de 2002.)

\footnotetext{
${ }^{65}$ Criado em 1963, por Stan Lee e Jack Kirby, a princípio, era apenas sargento de um destacamento militar durante a Segunda Guerra Mundial, suas aventuras foram publicadas na revista Sgt. Fury and his Howling Commandos entre 1963 e 1981. No decorrer dos anos, no mundo dos quadrinhos, ele adquiriu a patente de Coronel e se tornou chefe de uma super agência de espionagem do governo americano a S.H.I.E.L.D..

66 "You need me? Look around. They need me. The ones who might have five minutes of breath or blood left before they die." (tradução nossa) Captain America nº 1, p.19, jun. 2002.
} 
Sem nada poder fazer, frente à força do Capitão América, Fury vai embora e deixa o herói ajudando as vítimas. Ao desafiar seu superior, percebemos que o Capitão América optou por ficar do lado do povo (das vítimas) e não do lado do governo americano (representado por Nick Fury). Há uma estrutura militar na ação do super-herói, mas ela se mescla a um compromisso com outros cidadãos, desrespeitando a hierarquia de uma forma que sabemos jamais seria tolerada na caserna! É possível pensar também nesse universo narrativo, numa sutil diferença entre sociedade civil e aparelho de estado, com a solidariedade entre cidadãos priorizada.

Essa solidariedade do personagem e a opção por não ir lutar no Afeganistão são acompanhadas por um discurso contra o ódio. Isso fica evidente no momento em que o Capitão encontra com um jovem árabe-americano saindo de seu emprego em um mercado. Steve adverte o jovem que ele não deveria andar sozinho pelas ruas tão tarde, na mesma cena, podemos perceber um grupo de homens seguindo o rapaz. Ao ser advertido, o jovem diz: “Eu moro aqui. Meu nome é Samir, não Osama. Meu pai nasceu nesta rua..."67 - evidência de que existe uma comunidade árabe-americana alheia ao terrorismo.

Na sequência, Samir é atacado por um dos homens que o estavam seguindo. O homem o acusa de ter "matado Jenny". O ataque do homem é impedido pelo repentino aparecimento do escudo do Capitão América, novamente o herói diz que os americanos devem ser mais fortes do que nunca, senão os inimigos "terão vencido".

Aqui, percebemos que os autores procuraram estabelecer uma crítica a ações movidas por um ódio cego que, em vez de ajudar os americanos, estava prejudicando e enfraquecendo todos e, na visão deles, esta é a vontade do inimigo. Essa parte da HQ está em consonância com um trecho do discurso de George W. Bush ao Congresso, no dia 20 de setembro de 2001, no qual ele diz que: "O inimigo da América não são nossos amigos muçulmanos. Nossos amigos árabes. Nosso inimigo é uma rede terrorista radical e todos os governos que os apoiam." (BUSH, 2001) ${ }^{68}$.

Agressões contra membros da comunidade árabe-americana e contra mulçumanos foram recorrentes na agitação que se seguiu aos atentados. Na tentativa de conter essas agressões, as declarações feitas pelo presidente explicando quem eram os inimigos que, de fato, deveriam ser combatidos não foram o suficiente. Também foi necessário que o

\footnotetext{
67 "I live here. My name’s Samir not Osama. And my father was born on this street..." (tradução nossa) Captain America ${ }^{\circ} 1$, p.25, jun. 2002.

68 "The enemy of America is not our many Muslim friends. It is not our many Arab friends. Our enemy is a radical network of terrorists and every government that supports them.” (tradução nossa).
} 
Congresso norte-americano emitisse, em 26 de setembro de 2001, a "Resolução Antiintolerância" (H. Con. Res. 227), documento no qual afirmava que:

Considera-se que todas as comunidades árabe, sul-asiáticas e mulçumanoamericanas são uma parte vital da nação, [...] Levando em consideração as ameaças de vingança e incidentes de violência que já ocorreram contra americanos patrióticos, cumpridores da lei descendentes de sul-asiáticos e árabes [...] e seguidores da fé Islâmica. O Congresso (1) declara que, na busca de identificar, levar à justiça e punir os responsáveis e patrocinadores dos ataques terroristas contra os Estados Unidos em 11 de setembro de 2001, que os direitos civis e as liberdades civis de todos os americanos, incluindo Árabe-americanos, os muçulmano-americanos e norte-americanos do Sul da Ásia, devem ser protegidos, e (2) condena qualquer ato de violência e discriminação contra qualquer americano, incluindo árabeamericanos, os muçulmanos americanos e os americanos do sul da Ásia. ${ }^{69}$

Nesse ponto, nota-se que os autores da HQ procuraram transmitir a mesma mensagem de tolerância e união. Para vencer seus inimigos, "eles" (todos os Americanos), devem ser fortes e unidos como "povo e nação", têm que ser a "América" (Figura 7.). Aqui, surge uma importante questão: o que significaria ser a América?

Essa questão é parcialmente respondida no decorrer da narrativa; o Capitão América, ao conversar com o homem que atacou Samir, descobre que ele perdeu a filha no atentado e estava sedento por "justiça”, o herói diz que "isto não é justiça. Somos melhores que isso. Guarde sua raiva para o inimigo." ${ }^{70} \mathrm{Na}$ página seguinte, o Capitão deixa os homens conversando e segue pensando: "Nós vamos superar isto. Nós o povo. Unidos por um poder que nenhum inimigo da liberdade poderia entender. "71

De acordo com Dittmer,

Enquanto a intervenção do Capitão América demonstra o comprometimento da América com o multiculturalismo ${ }^{72}$ e a justiça, seu monólogo interior não serve apenas como uma proscrição para o comportamento dos americanos e

\footnotetext{
69 "Whereas the Arab-American, South Asian-American, and American Muslim communities are a vital part of our nation; [...]. Whereas vengeful threats and incidents of violence directed at law-abiding, patriotic Americans of Arab or South Asian descent, particularly the Sikh community, and adherents of the Islamic faith have already occurred: Now, therefore, be it Resolved by the House of Representatives (the Senate concurring), That the Congress (1) declares that in the quest to identify, bring to justice, and punish the perpetrators and sponsors of the terrorist attacks on the United States on September 11, 2001, that the civil rights and civil liberties of all Americans, including Arab Americans, American Muslims and Americans from South Asia, should be protected; and (2) condemns any acts of violence or discrimination against any Americans, including Arab Americans, American Muslims, and Americans from South Asia.” (tradução nossa).

70 "This ins't justice. We're better than this. Save your anger for the enemy." (tradução nossa) Captain America $\mathrm{n}^{\mathrm{o}} 1$, p.30, jun. 2002.

71 "We're going to make it through this. We the people. United by a power that no enemy of freedom could begin to understand.” (tradução nossa) Captain America nº1, p.32, jun. 2002.

$72 \mathrm{O}$ compromisso de Bush com o multiculturalismo fez parte de suas promessas de campanha e foi uma das propostas que ele tentou colocar em prática durante seus dois mandatos. Para maiores informações sobre como isso foi desenvolvido, ao longo do governo, ver o artigo de Gary Gerstle: "Minorities, Multiculturalism, and presidency of Gerorge W. Bush" In: ZELIZER, Julian E..(Edit.) The presidency of George W. Bush: a first historical assessment. New Jersey: Princeton University Press, 2010. (p.252-281).
} 
também como uma afirmação do poder militar americano, mas, simultaneamente, constrói a identidade, tanto da América quanto dos terroristas, como partes de uma dicotomia entre os que amam a liberdade e os que odeiam a liberdade que exclui outras possibilidades. (2005, p.638, tradução nossa) $)^{73}$

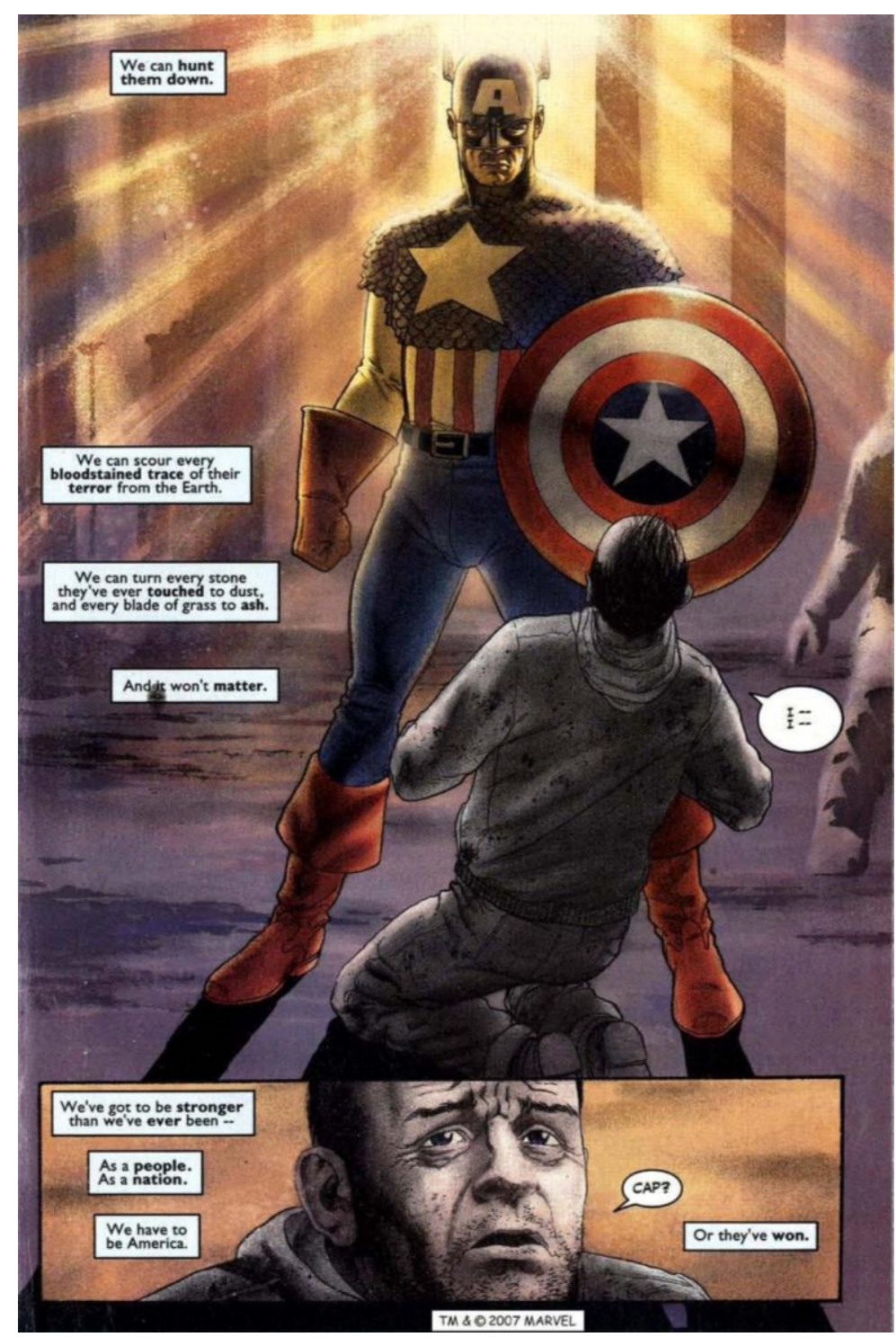

Figura 7. O herói é mostrado como alguém capaz de trazer a "luz" a esse momento de escuridão. (Captain America nº1 p.29, junho de 2002.)

Essa diferenciação também é feita pelo presidente Bush em outra parte do discurso, citado anteriormente, ao explicar por que os terroristas odeiam os EUA, ele diz que:

Eles odeiam o que o veem bem aqui nessa Câmara: um governo democraticamente eleito. Seus líderes são autodesignados. Eles odeiam

\footnotetext{
73 "While Captain America's intervention demonstrates America's commitment to multiculturalism and justice, his inner monologue serves not only as a proscription for American behavior and a statement of American military power, but also simultaneously constructs both the meaning of America and the terrorists' identity as parts of a freedom-loving/freedom-hating dichotomy that fore- closes other possibilities." (DITTMER, 2005, p.638).
} 
nossas liberdades: nossa liberdade religiosa, nossa liberdade de expressão, nossa liberdade de votar e de reunir-se e de discordar uns dos outros. ${ }^{74}$

Definir de forma precisa a identidade nacional dos Estados Unidos é uma tarefa bem difícil, a qual não é o objetivo deste trabalho, entretanto, os autores da HQ e o discurso presidencial fornecem algumas interpretações dessa identidade. Em ambos os documentos, os Estados Unidos e seu povo são definidos como amantes da democracia e da liberdade, já seus inimigos “odeiam” ou, no mínimo, "não entendem" esses conceitos.

A "Liberdade" é apresentada como um conceito que caracteriza os norte-americanos. De acordo com o historiador, Eric Foner: "Nenhuma ideia é mais fundamental para os americanos compreenderem a si mesmos como indivíduos e como nação do que a liberdade." $(1999 \text {, p.xiii, tradução nossa })^{75}$. Mesmo sendo tão importante para os norte-americanos, não se produziram muitas discussões abstratas sobre o conceito de liberdade. Para Foner,

[...] a liberdade não incorpora apenas uma ideia, mas um complexo de valores, o empenho em definir seus significados é simultaneamente uma discussão intelectual, social, econômica e política. Uma ideia moralmente carregada, a liberdade tem sido usada para transmitir e reivindicar legitimidade para todos os tipos de queixas e esperanças, temores sobre o presente e visões do futuro. Liberdade é um dos mais velhos clichês e uma das mais modernas aspirações. Em vários tempos de nossa história ela serviu como um "ideal de protesto" e como uma justificativa do status quo. Liberdade ajuda a manter nossa cultura unida e expõe as contradições entre o que a América pretende ser e o que ela verdadeiramente é. (1999, p. xvxvi, tradução nossa) ${ }^{76}$

São essas contradições que John Ney Rieber, o roteirista dessa série, se propôs a discutir com esse trabalho, nas palavras dele: "Eu acredito que ele [o Capitão América] considera a história da nação como uma luta entre o Sonho Americano e a Realidade Americana". ${ }^{77} \mathrm{O}$ "Sonho Americano" é outro elemento que a HQ aponta como caracterizador da sociedade

\footnotetext{
74 "They hate what they see right here in this chamber: a democratically elected government. Their leaders are self-appointed. They hate our freedoms: our freedom of religion, our freedom of speech, our freedom to vote and assemble and disagree with each other." (tradução nossa).

75 "No idea is more fundamental to American's sense of themselves as individuals and as a nation than freedom." (FONER, 1999, p.xiii).

76 " [...] freedom embodies not a single idea but a complex of values, the struggle to define its meaning is simultaneously an intellectual, social, economic, and a political contest. A morally charged idea, freedom has been used to convey and claim legitimacy for all kinds of grievances and hopes, fears about the present and visions of the future. Freedom is the oldest of clichés and most modern of aspirations. At various times in our history it has served as a "protest ideal" and as a justification of the status quo. Freedom helps bind our culture together and exposes the contradictions between what Americas claim to be and what it actually is." (FONER, 1999, p.xv-xvi).

77 "I believe that he considers the history of the nation as a struggle between the American dream and the American reality." (tradução nossa) Entrevista disponível em:< http://www.buzzcomics.net/archive/index.php/t498.html > Acesso em: 23/01/2013.
} 
estadunidense e que abordaremos posteriormente. No momento, vamos nos ater a como os autores apresentaram as contradições da sociedade norte-americana pós-11 de setembro.

Apesar de definirem o povo americano quase da mesma maneira, a HQ e o discurso do presidente Bush apresentam algumas diferenças. $\mathrm{O}$ presidente afirma que os terroristas teriam raiva das liberdades e do governo democrático dos Estados Unidos, e por isso:

Estes terroristas matam não apenas para acabar com vidas, mas para desorganizar e acabar com um modo de vida. Com cada atrocidade, eles esperam que a América cresça apavorada, que se afaste do mundo, e abandonando nossos amigos. Eles estão contra nós, porque estamos em seu caminho. (BUSH, 2001) ${ }^{78}$

Nessa parte do discurso, notamos que os EUA são caracterizados como um país de valores democráticos, onde seu povo goza de diversas liberdades, e isso é um fato que desperta o ódio de seus inimigos. Do ponto de vista de Bush, o modo de vida e a organização político-social dos Estados Unidos apresentam-se como inimigos "naturais" das ideologias dos terroristas, comparáveis à dos nazifascistas que também "sacrificam vidas humanas para servirem a sua visão radical, abandonando todos os valores, exceto a busca pelo poder. [...] E eles seguirão por esse caminho até terminarem numa sepultura anônima da história das mentiras descartadas. " (BUSH, 2001). ${ }^{79}$

Percebe-se, nessa comparação, que os valores (ideologia) dos EUA seriam "melhores" do que os dos terroristas e de seus similares no passado. Ademais, ao fazer a comparação entre terrorismo islâmico e nazifascismo, tem-se a construção de um forte argumento para legitimar ainda mais a Guerra ao Terror que, desse ponto de vista, seria tão indispensável quanto foi a ação dos EUA, durante a Segunda Guerra Mundial. A fala do presidente dá a entender que os EUA não têm nenhuma culpa pelo que ocorreu, a ação dos terroristas foi motivada simplesmente por esse ódio sem motivo aos americanos e a tudo que eles representam.

Além dessa alegada inocência também fica evidente uma concepção maniqueísta explicitada nas últimas palavras do discurso presidencial:

O decurso deste conflito não é conhecido, mas seu resultado é certo. Liberdade e medo, justiça e crueldade, sempre estiveram em guerra, e nós sabemos que Deus não é neutro entre eles. Concidadãos, nós vamos enfrentar violência com justiça paciente, certos da retidão de nossa causa e confiantes na vitória que virá. Em tudo que está diante de nós, que Deus nos

\footnotetext{
78 “These terrorists kill not merely to end lives, but to disrupt and end a way of life. With every atrocity, they hope that America grows fearful, retreating from the world and forsaking our friends. They stand against us because we stand in their way." (tradução nossa).

79 "By sacrificing human life to serve their radical visions, by abandoning every value except the will to power, they follow in the path of fascism, Nazism and totalitarianism. And they will follow that path all the way to where it ends in history's unmarked grave of discarded lies." (tradução nossa).
} 
dê sabedoria, e que ele possa dar assistência aos Estados Unidos da América. (BUSH, 2001) 80

Ao delimitar o papel que o povo americano e as outras nações do mundo deveriam ter nessa guerra contra o terrorismo, fica claro que: todos que estivessem do lado dos EUA, estariam do lado do "Bem" (da liberdade, da igualdade, da tolerância e de Deus). Já quem não estivesse disposto a ajudar nessa batalha, estaria do lado dos terroristas ou do lado do "Mal".

\subsection{Culpa X Inocência}

Nas HQs, os autores expressam uma opinião diferente da do presidente. A ideia de inocência dos Estados Unidos é questionada a partir da terceira edição da série, quando o terrorista Al-Tariq está mantendo todas as pessoas da cidade de Centerville presas na igreja explica o porquê de ter escolhido eles como suas vítimas:

Alguns de vocês devem estar perguntando ao seu Deus. Por que irão morrer hoje. Alguns de vocês sabem. Aqueles que trabalham na fábrica de bombas. Na periferia dessa pacífica cidade. Hoje, vocês vão aprender o significado de... Quem semeia vento colhe tempestade. ${ }^{81}$

Punir a população dessa cidade que fabrica bombas é uma das motivações de Al-Tariq. Enquanto isso ocorre, o Capitão América é obrigado a lutar contra um grupo de garotos usando roupas estereotipadas de árabes (panos enrolados na cabeça que deixam só os olhos à mostra) - e que obedecem às ordens de Al-Tariq. O Capitão procura se esquivar dos ataques dos garotos, pois ele não quer lutar contra crianças, diz: "Imobilize-os. Aqui é a América... nós não fazemos guerra... com crianças. "82

Diante disso, Al-Tariq responde: "Não? Então americano conte as nossas crianças. Quem semeou a morte em seus campos... e deixou para que inocentes a colhessem? Quem arrancou suas mãos? Seus pés?"83. Nessa parte é mostrado que, no lugar de mãos e pés, os garotos usam próteses metálicas e, nos dois últimos quadros, vemos os tão jovens "mutilados" encarando o Capitão que demonstra estar surpreso com essa revelação (Figura 8.). O

\footnotetext{
80 "The course of this conflict is not known, yet its outcome is certain. Freedom and fear, justice and cruelty, have always been at war, and we know that God is not neutral between them. Fellow citizens, we'll meet violence with patient justice, assured of the rightness of our cause and confident of the victories to come. In all that lies before us, may God grant us wisdom, and may he watch over the United States of America." (tradução nossa).

81 "Some of you are asking your God. Why you will die today. Some of you know. Those of you who work at the bomb manufacturing facility. At the edge of this peaceful town. Today you learn what means...to sow the wind. And reap the whirlwind." (tradução nossa) Captain America n³, p.03, ago. 2002.

82 "Call them off. This is America...We don’t make war...on children." (tradução nossa) Captain America n³, p.05, ago. 2002 .

83 "No? Tell our children then American... who sowed death in their fields... and left it for the innocent to harvest? Who took their hands? Their feet?” (tradução nossa) Captain America n³, p.06, ago. 2002.
} 
personagem, como cidadão americano, revela ignorar essa dura experiência do inimigo que, talvez, até o espante. Será aquilo também obra de seu povo?


Figura 8. Crianças vítimas de minas terrestres deixadas pelo exército americano em seus países. (Captain America $\mathrm{n}^{\circ} 3$ p. 06, julho de 2002.)

Isso faz com que o Capitão América reflita sobre o perigo de minas terrestres e granadas que "sobrevivem às guerras", que afetam muitos inocentes em vários locais. O Capitão esboça uma grande preocupação com isso, mas deixa claro que se trata de uma luta para outro momento, pois ele deve concentrar-se em sua missão de resgate e diz a si mesmo: "Mantenha o foco, soldado. Você só pode lutar uma batalha por vez... e sua batalha é aqui., 84

\footnotetext{
84 "Focus, soldier. You can only fight one battle at a time...And you battle is here." (tradução nossa) Captain America n³, p.08, ago. 2002.
} 
Na sequência, o herói tenta se desvencilhar dos garotos, um deles o ataca por trás com uma faca, enquanto outro mostra ao herói que está carregando granadas presas ao peito e as detona. O Capitão se joga para cima do garoto que o atacava com a faca a fim de protegê-lo da explosão. Após ser "salvo" pelo Capitão (que absorveu boa parte da explosão com seu corpo), o garoto diz: "Você... Al-Tariq mentiu? Você não é o inimigo...",85. Ele diz para o garoto que, nem ele nem as pessoas que estão feitas reféns, são seus inimigos, e vai na direção da igreja, porém o garoto o detém, dizendo: "se você for lá ajudá-los... todos vão morrer." 86 Há sinais de desconhecimento e descoberta recíprocos, a narração apresenta um mundo obscuro para seres que se consideram inimigos, mas descobrem fragmentos de valores em comum. O inimigo, portanto, pode ser mais que isso - talvez apenas outro ser humano com potencialidades e perplexidades.

Dentro da igreja, vemos uma cena em que uma mulher questiona seu marido: " $E$ assim que você alimenta nosso bebê? Com bombas? Fazendo bombas? "87. Ele nega e diz que eles só fazem "componentes" de bombas. Aqui se percebe que o homem procura negar que produza armas letais, dizendo fazer apenas componentes delas, pois para ele, isso seria algo melhor do que produzir bombas completas. Nesse sentido, os argumentos dos terroristas revelam alguma dose de verdade, embora sua ação seja radicalmente rejeitada pela narração.

No decorrer da HQ, os autores apresentam um interessante diálogo entre o terrorista Faysal Al-Tariq e a repórter, Jessica Seldon, que está fazendo a cobertura do incidente em Centerville. Ela apresenta Al-Tariq como líder dos terroristas que nega isso e, enquanto aponta uma arma, diz que não é um terrorista, é só "um mensageiro”. Dirigindo-se ao povo norte-americano, através das câmeras de TV, declara: "estou aqui para lhes mostrar a verdade da guerra. Vocês são os terroristas! ",88.

Ao mesmo tempo em que isso ocorre, o Capitão América abre caminho por entre seus inimigos para chegar até a igreja, e faz algumas reflexões sobre o que é a guerra: "A guerra é o inferno... quando o campo de batalha não lhe dá alternativas. [...] Quando o inimigo não lhe deixa escolha." ${ }^{89}$ Aqui, os pensamentos do herói servem como uma justificativa pela necessidade de ter que tirar a vida de seus oponentes, afinal, eles não lhe deram alternativa.

\footnotetext{
85 "You... Did Al-Tariq lie? You are not the enemy..." (tradução nossa) Captain America n³, p.13, ago. 2002.

86 "If you go to them. To help them...you all die.” (tradução nossa) Captain America n³, p.14, ago. 2002.

87 "This how you feed our baby? Whit bombs? You make bombs?"/"No! Components...We make components." (tradução nossa) Captain America n³, p.16, ago. 2002.

88 "I am a Messenger... here to show you the truth of war. You are the terrorists!" (tradução nossa) Captain America n⿳3, p.20, ago. 2002.

89 "War is hell... When battlefield gives you no alternative. When the enemy leaves no choose." (tradução nossa) Captain America n³, p.21, ago. 2002.
} 
Depois, ele questiona por qual razão os Estados Unidos são "odiados": "Somos odiados simplesmente por sermos livres... Livres, prósperos e bons? Ou a luz que vemos lança sombras que não vemos... Onde monstros como esse Al-Tariq podem plantar as sementes do ódio?".

Essa fala do herói apresenta-se como uma crítica à fala do presidente Bush. Simultaneamente, Al-Tariq segue "discursando" contra os Estados Unidos: "Quando americanos inocentes morrem... é uma atrocidade. Mas, quando nós morremos... somos "danos colaterais"!,"90 Em meio a essa fala de Al-Tariq, vemos o Capitão derrubando mais oponentes, ele conclui que no momento seus questionamentos "não importam, nada importa... exceto as pessoas”. Quais pessoas? A resposta parece ser: os nossos!

Al-Tariq diz que: "Quando americanos morrem, deve ser feita justiça..."; ele é interrompido pelo herói que grita "Não! Não quando nós morremos. Enquanto estamos vivos!". Dizendo esta última frase, o Capitão arremessa seu escudo contra Al-Tariq. Mesmo derrubado pelo escudo, Al-Tariq tenta alcançar o detonador, dizendo: “É bom que esteja aqui para saborear esta justiça... Americano. "91 Agora, o Capitão tem apenas uma chance para deter Al-Tariq e salvar os reféns. Ele segura a mão de Al-Tariq, impedindo-o de apertar o botão do detonador, e o ataca violentamente. A batalha termina com a morte de Al-Tariq.

O Capitão América pede para a repórter dizer às pessoas que estão na igreja que já podem sair, pois está tudo em segurança. Finalizando essa edição, vemos o Capitão em frente à câmera de TV dando um importante depoimento ao "povo" (Figura 9.):

De onde estou... Eu não vejo guerra. Vejo ódio. Vejo homens, mulheres e crianças morrendo... Porque o ódio é cego. Cego o suficiente... Para responsabilizar uma nação inteira pelas ações de um só homem. Eu não posso fazer parte disso. Depois do que vi hoje. A América não matou Faysal Al-Tariq. Eu matei." 92 (nesse momento ele tira a máscara e revela sua identidade secreta a todos).

Nessa parte, é evidente que: ao expor sua identidade ao público, o Capitão América assume a culpa e as consequências de seus atos, como indivíduo. A culpa é dele, ele é que deve sofrer pelo que fez, não o povo de seu país; nesse momento, ele renega sua função de

\footnotetext{
${ }^{90} \mathrm{O}$ texto original é o seguinte: Capitão America - "Are we only hated because we're free... Free, prosperous and good? Or does the light that we see cast shadows that we don't... Where monsters like this Al-Tariq can plant the seed of hate?/ Al-Tariq - "When innocent Americans die is an atrocity. But when we die... we are "collateral damages."” (tradução nossa) Captain America n³, p.22, ago. 2002.

${ }^{91} \mathrm{O}$ texto original, na ordem que citamos, é o seguinte: Al-Tariq - "When Americans die there must be justice..."/ Capitão América - "No! Not when we die. While we live!"/ Al-Tariq - "Hah! It is good that you are here. To taste this justice... American." (tradução nossa) Captain America n³, p.24 e 25, ago. 2002.

92 "Where I stand... I don't see war. I see hate. I see men and women and children dying... Because hate is blind. Blind enough... To hold a nation accountable for the actions of a man. I can't be part of that. After I've seen today. America didn’t kill Faysal Al-Tariq. I did.” (tradução nossa) Captain America n³, p.30 a 32, ago. 2002.
} 
símbolo representante dos EUA e, com isso, espera evitar que mais mortes ocorram. Revelar sua identidade é um ato de autossacrifício, ele prefere sofrer sozinho a ver mais pessoas morrendo. A mensagem é clara, nenhum povo deve ser castigado pelas ações de seus líderes.

As críticas e os questionamentos expostos pelos autores das HQs, de certa forma, fazem parte das discussões que ocorreram nos Estados Unidos, após os atentados e o início da Guerra ao Terror. São um aprofundamento das questões expostas no discurso do presidente Bush, somadas ao questionamento de quais seriam as reais intenções dessa nova guerra e que papel os EUA deveriam ter diante desse novo cenário que se apresentava.
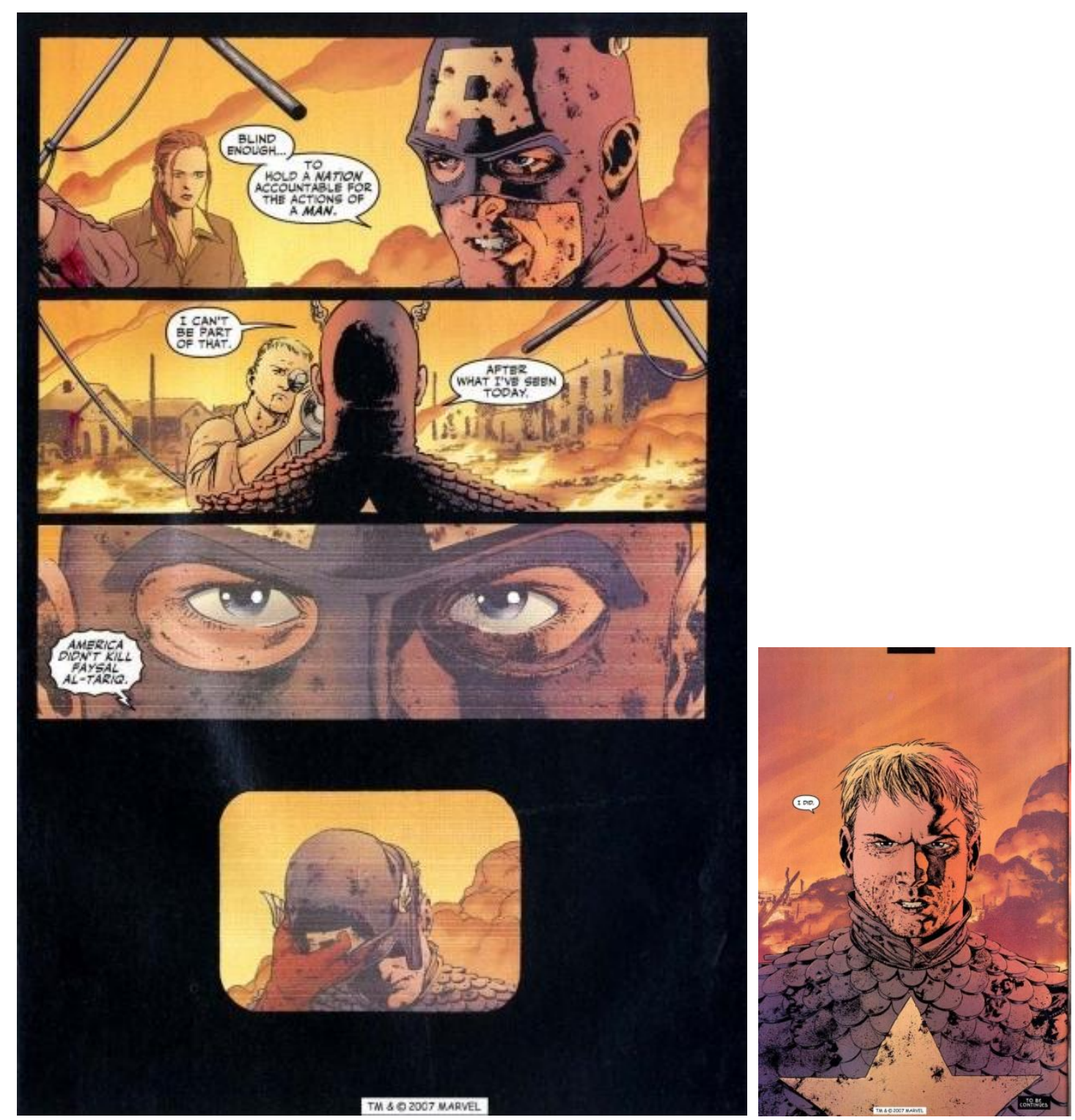

Figura 9. O herói assume sua culpa e expõe sua identidade a todos. (Captain America n $\mathrm{n}^{\circ}$ p. 31e 32, julho de 2002.) 
O historiador Mike Davis (2008), em um artigo intitulado "O fim da excepcionalidade norte-americana" 93 , discute como os dois lados dessa "guerra" (EUA e extremistas islâmicos) trocam acusações, nas quais, de alguma maneira, cada lado procura justificar seus atos de violência com outros atos de violência. Davis busca evidenciar como esse tipo de ação não é benéfico para nenhuma das partes envolvidas. Além disso, faz importantes críticas à ação dos EUA no "mundo muçulmano", que ele classifica como "antidemocráticas e criminosas" (2008, p.24), mas a população dos EUA não pode nem deve ser responsabilizada pela ação de seus governantes - como vimos, essa é uma das reflexões que a HQ do Capitão América levanta -; do mesmo modo, a população do Afeganistão também não deve sofrer ainda mais pelo apoio que seus governantes dão à Al-Qaeda. Apesar de terem cometido muitas "atrocidades" condenáveis em diversos momentos e locais, Davis diz que não está acusando os Estados Unidos de serem

o principal promotor de todo o mal e toda a desigualdade no mundo muçulmano, a personificação do "Grande Satã", evocado nas preces fundamentalistas. Não, as reacionárias classes dominantes locais são, em última instância, os maiores inimigos da democracia, do feminismo, dos direitos das minorias e da justiça social no mundo árabe e, de modo mais geral, no islâmico. O imperialismo britânico, francês e soviético da era Brejnev, ao lado de Israel também ajudaram a roubar os sonhos das populações árabes. (2008, p.25)

Assim, constata-se que Mike Davis procurou dividir a "culpa" da (ou responsabilidade pela) atual situação do "mundo muçulmano" entre diferentes agentes históricos que, ao longo do tempo, têm agido na região.

Em uma entrevista concedida em 19 de setembro de $2001^{94}$, Noam Chomsky, na mesma linha argumentativa de Mike Davis, afirma que os atentados de 11 de setembro foram "algo inteiramente novo na política mundial, não em sua dimensão ou caráter, mas, em relação ao alvo atingido." (p.11 e 12). Segundo ele, ao longo de anos, os EUA e os países europeus, de modo geral, vêm praticando atos de violência para impor seus interesses em diversas partes do mundo, gerando um grande número de vítimas. Mas, com o 11 de setembro, pela primeira vez, essa violência voltou-se contra os EUA, ou, nas palavras de Chomsky, “as armas voltaram-se contra nós. Foi uma mudança dramática.” (2002, p.12).

Chomsky reafirma que essa "mudança dramática" foi alimentada pelas ações passadas dos EUA (bem como de seus antecessores europeus) na região do Oriente Próximo, que geraram um forte ressentimento contra qualquer coisa que fosse de origem americana. Sendo

\footnotetext{
${ }^{93}$ Esse artigo saiu, originalmente, em setembro de 2001 em uma "aula de protesto na Universidade estadual de Nova York".

${ }_{94}$ Publicada no Brasil em 2002, juntamente com outras entrevistas, no livro "11 de setembro".
} 
assim, a Guerra ao Terror, juntamente com outras medidas propostas para lidar com a crise, tendem a intensificar o ressentimento e o ódio contra o Ocidente. Além disso, ele diz que essa Guerra ao Terrorismo

é simplesmente uma boa dose a mais de propaganda, a não ser que a guerra tenha como alvo, de fato, o terrorismo. Mas, não é o que está ocorrendo, pelo menos, não sem subterfúgios, já que as potências ocidentais não poderiam assumir suas próprias definições do termo, como no U.S. Code ${ }^{95}$ ou nos manuais do Exército. Se o fizessem, isso revelaria de imediato que os Estados Unidos são um Estado líder do terrorismo, assim como os países que se constituem seus principais aliados. (CHOMSKY, 2002, p.17)

Essa acusação, feita por Chomsky, vai ao encontro de uma declaração feita pelo personagem Al-Tariq na terceira edição da revista do Capitão América (p.20), citada acima, mas, diferentemente do personagem dos quadrinhos, Chomsky não acredita e nem defende os atos terroristas praticados contra os EUA como sendo a melhor forma de resolver todos os problemas causados por anos de dominação imperialista. Seu objetivo é expor pontos importantes que deveriam ser discutidos pela opinião pública e pelos meios de comunicação norte-americanos, e poderiam levar à escolha de ações menos violentas e precipitadas do que foi a invasão do Afeganistão.

As opiniões de Davis e Chomsky têm um tom anti-imperialista evidente e, em linhas gerais, propõem que a atual ação norte-americana no Oriente Médio (e no mundo, de modo geral) seja reavaliada, em busca de soluções pacíficas e mais humanas para os conflitos.

Contrapondo-se a essa visão anti-imperialista, o historiador britânico, Niall Ferguson, afirma que a solução para a crise gerada pelos atentados de 11 de setembro está na criação de um "império formal" norte-americano. Para Ferguson,

Os EUA precisam empenhar-se mais para impor a ordem nos estados delinquentes. A ideia de invadir um país, depor seus ditadores e impor à força respeito à lei, costuma ser desprezada por ser incompatível com os valores americanos. Um argumento frequente é que os Estados Unidos jamais poderiam envolver-se no tipo de dominação imperial aberta praticada pela Inglaterra no século XIX. Contudo, as pessoas se esquecem de que foi exatamente isso que fizemos na Alemanha e no Japão, após a Segunda Guerra Mundial - e com grande e duradouro sucesso. (2002, p.145 e 146)

\footnotetext{
${ }^{95}$ Segundo esse documento citado por Chomsky, "ato de terrorismo quer dizer qualquer atividade que $a$ ) envolva um ato violento ou uma séria ameaça à vida humana que seja considerado delito pelos Estados Unidos ou qualquer outro Estado, ou que seja delito assim reconhecido, se praticado dentro do território jurisdicional americano ou de qualquer outro Estado; e $b$ ) aparente (i) ser uma intimidação ou coerção à população civil; (ii) influencie a política governamental por meio de intimidação ou coerção; ou (iii) ameace a conduta de um governo por um assassinato ou sequestro." (United States Code Congressional and Administrative News. $98^{\circ}$. Congresso, Segunda Sessão, 19 de outubro de 1984, volume 2, parágrafo 3077,98 STAT.2707\{ West Publishing Co., 1984\}).
} 
Ferguson vê na dominação imperial, por parte dos EUA, a melhor maneira de se evitar fragmentações político-ideológica - como o fundamentalismo religioso e guerras civis - e "fazer do mundo um lugar seguro para o capitalismo e a democracia” (2002, p.146). O "império formal" norte-americano deveria investir dinheiro na criação de instituições que garantiriam a "lei e a ordem" onde estas não existam e, com isso, os EUA também poderiam ter grandes lucros "pois, o estabelecimento do respeito à lei em tais países geraria dividendos a longo prazo, à medida que seu comércio renascesse e se expandisse." (2002, p.147).

Ao finalizar seu texto, Ferguson elenca três motivos que impedem que os EUA assumam esse papel de líder imperial: “(1) constrangimento ideológico diante da possibilidade de pensarem que estaríamos lançando mão de um poder imperial; (2) uma ideia exagerada das respostas da Rússia e da China; e (3) um temor pusilânime de baixas militares." (FERGUSON, 2002, p.147).

Além disso, ele deixa uma questão que vale ser objeto de reflexão: "Será que os líderes do único estado detentor de recursos econômicos suficientes para fazer do mundo um lugar melhor vão ter coragem para tanto?" (FERGUSON, 2002, p.147). Em linhas gerais, o que Ferguson defende é que os EUA tenham uma postura mais ativa e condizente com seu poder econômico e militar, estabelecendo um "verdadeiro" império, aos moldes britânicos, com colônias onde a administração direta americana seria a melhor maneira de se evitar novos conflitos e ameaças para a segurança mundial. Mas, para isso, há grandes investimentos a serem feitos e consequências que devem ser assumidas, como as já citadas, baixas militares e reações de outras nações. Ele apresenta uma visão positiva do imperialismo que contradiz a visão, tanto dos fundamentalistas islâmicos quanto dos autores de esquerda expostos acima, além de ignorar o destino dos imperialismos predecessores.

Complementando a análise de Ferguson, noutra direção, o historiador Paul Kennedy afirma que, nesse momento de crise, a melhor escolha que os EUA podem fazer para manter seu poder é investir, sobretudo, em ações diplomáticas, pois "a própria natureza da ameaça terrorista internacional, bem como a delicadeza das relações norte-americanas com o mundo muçulmano, colocam a diplomacia inteligente em um lugar de especial valor." (KENNEDY, 2002, p.86).

Kennedy, assim como Ferguson, acredita que nesse momento, pós-atentados, é necessário que os EUA procurem manter seu poder, mas ele discorda da ideia de reestabelecimento de um domínio imperial e fundamenta sua interpretação dizendo:

Uma coisa é atacar as bases terroristas e regimes brutais, a título de punição. Outra, muito diferente, é o policiamento imperialista pela 
democracia americana: em termos políticos, provoca divisões e, em última instância, é um elemento debilitador - portanto, contrário a uma estratégia razoável para a manutenção do poder norte-americano no século XXI. (KENNEDY, 2002, p.89)

A opinião de Kennedy apresenta uma estratégia mais comedida, menos arbitrária para se combater os problemas expostos. Além disso, a visão dele quanto ao imperialismo reflete a "relutância" dos Estados Unidos em se assumirem como uma nação imperial. Em seu livro "Habits of Empire” (2008), o historiador norte-americano, Walter Nugent, afirma que uma das razões para essa relutância

\begin{abstract}
pode ser devido ao que eles compreenderam do exemplo Romano e, mais recentemente, dos Britânicos, que impérios declinam e caem. Mas, fronteiras (incluindo as fronteiras de povoamento), missões, e destinos manifestos supostamente não deveriam declinar. Em vez disso, eles expandem. Indefinidamente. A experiência e os propósitos dos americanos são vistos como a "expansão da área da terra livre" e como a substituição da "selvageria" pela "civilização"[...] é tudo sobre começos, não fins. Os americanos continuam pensando em começos e negam os fins. Eles são orientados para o futuro. Admitindo ser um império poderia ser como admitir que os Estados Unidos, um dia, de algum jeito, podem declinar e cair. Mas, isto pode contradizer o senso histórico de missão que a nação tem. Como os Estados Unidos poderiam espalhar autonomia ${ }^{96}$, democracia, liberdade e livre empreendimento, se isso pode declinar e cair? Esses são valores perenes, parte dos direitos humanos e da natureza humana no seu melhor, ou não são? (p.316, tradução nossa) ${ }^{97}$
\end{abstract}

Tal relutância em admitir-se como um império de proporções globais está ligada com o que o Sidney Lens (2003) chama de "mito da moralidade" e, de acordo com o autor, "Os Estados Unidos, como outras nações, elaboraram um mito de moralidade para aliviar sua consciência e sustentar sua imagem." (p.21). Esse mito contribui para a construção da imagem de inocência dos Estados Unidos. Pelo viés deste mito, ações militares e expansionistas dos EUA são interpretadas como moralmente justas, pois

os Estados Unidos têm sido antibelicosos, anti-imperialistas, anticolonialistas.[...] De modo geral, de acordo com o mito, os Estados Unidos têm respeitado religiosamente os direitos de outros povos de determinar seus próprios destinos: sempre foram solidários a lutas

\footnotetext{
${ }^{96} \mathrm{O}$ texto original logo abaixo apresenta a palavra liberty e também a palavra freedom, que em português são traduzidas da mesma maneira. Como a palavra liberty abarca um sentido mais político ligado à independência, optamos por traduzi-la por autonomia, o sinônimo mais próximo, tanto no português quanto no inglês.

97 "One reason may be that they have understood from Roman example and more recently, the British, that empires decline and fall. But frontiers (including settlement frontiers), missions, and manifest destinies are not supposed to. Instead they expand. Indefinitely. The American experience and purpose, seen as the "expansion of the area of a free land" and the replacement of "savagery" with "civilization", [...] was all about beginnings, not endings. Americans still thinking about beginnings and deny the ending. They are future-oriented. Admitting to being an empire would be admitting that the United States some day, in some way, will decline and fall. But that would contradict the nation's historic sense of mission. How could the United States spread liberty, democracy, freedom, and free enterprise if it decline and fell? Those are perennial values, part of human rights and human nature at its best, are they not? (NUGENT, 2008, p.316).
} 
revolucionarias que buscassem a genuína independência, sempre se abstiveram de intervir nas questões internas de outras nações, grandes ou pequenas, poderosas ou fracas. Mais que qualquer outra grande nação, têm sido guiados por uma desprendida preocupação com os menos afortunados. (LENS, 2003, p.21)

Sidney Lens também afirma que, de fato, essa "América generosa não existe e nunca existiu” (Ibidem) e que, ao longo de sua história, os Estados Unidos têm feito é exatamente o oposto do que esse mito prega, eles "[...] têm imposto sua vontade sobre inúmeras nações, contra os desejos e interesse delas; têm violado centenas de tratados e acordos; têm cometido crimes de guerra tão chocantes quanto numerosos [...]”. (LENS, 2003, p.21-22). Nas HQs, isso é apresentado como um fato que não era de conhecimento de muitos dos cidadãos dos Estados Unidos - o próprio Capitão América, que já havia estado em campos de batalha, se mostra surpreso ao ver os jovens mutilados - eles desconhecem o mundo a sua volta e as consequências das ações de seu país, apresentam uma inocência que é proveniente de sua ignorância.

$\mathrm{Na}$ última edição da série, o Capitão é novamente exposto às consequências das ações de seu país em outras partes do mundo; enquanto lutam, o Mestre dos terroristas conta ao herói sua trágica origem e a participação que os Estados Unidos tiveram na tragédia pessoal que motiva a ação do inimigo:

Não há plantações no inferno de onde eu vim. Sem sementes, sem colheitas... Não agora. Mas já houve. Guerrilheiros atiraram no meu pai enquanto ele trabalhava nos campos. Com balas e armas Americanas. De onde eu venho? Meu pai não sabia que a Guerra Fria estava no seu auge... Lembra? De quando os soviéticos eram seus grandes inimigos? O império do mal? Minha mãe não sabia que nossa nação estava na agonia de uma guerra civil não declarada entre os seus aliados e os aliados do mal. Quando ela correu para achar seu marido. Minha mãe foi interrogada e morta. Nosso lar foi queimado. O fogo me deu essa face. Mas, o fogo não fez de mim um monstro. Você sabe sua história, Capitão América. Diga a seu monstro de onde ele veio. ${ }^{98}$

Depois de "ouvir" essa declaração de seu inimigo, o Capitão tenta "defender" seu país, dizendo: "Nós mudamos. Nós aprendemos." 99 O inimigo responde: "Você não pode me responder, é isso que você quer dizer. Vocês jogaram esse jogo em muitos lugares... O sol

\footnotetext{
98 "There is no more planting in hell where I'm from. No seed, no harvest... Not now. But there was. Guerrillas gunned my father while he was at work in the fields... Wiht American bullets. American weapons. Where am I from? My father didn't know that the Cold War was at its height. Remember? When the Soviets was your great enemy? The evil empire? My mother didn't know that our nation was in the throes of an undeclared civil war between your allies and the allies of evil... When she ran to find her husband. My mother was interrogated and shot. Our home was burned. That fire gave me my face. But fire didn't make me a monster. You know your history, Captain America. Tell your monster where he's from." (tradução nossa) Captain America no 6, p.32 e 34, dez. 2002.

99 "We've changed. We’ve learned." (tradução nossa) Captain America nº6, p.35, dez. 2002.
} 
nunca se põe em seu tabuleiro de xadrez politico... em seu Império de sangue."100 O Capitão diz que o inimigo está errado, mas, ele continua, cita a "África, a Ásia e a América do Sul... Nós morremos e sua gente...”, ao dizer isso o Capitão o acerta um golpe no Mestre e diz: “Minha gente nunca soube! Agora nós sabemos. Esses dias estão acabados... Nós aprendemos com nossos erros. Mas, vocês... Você diz ter visto inocente morrendo... Conhece essa perda... Sentiu esse sofrimento. Você está cego!"101 (Figura. 10).

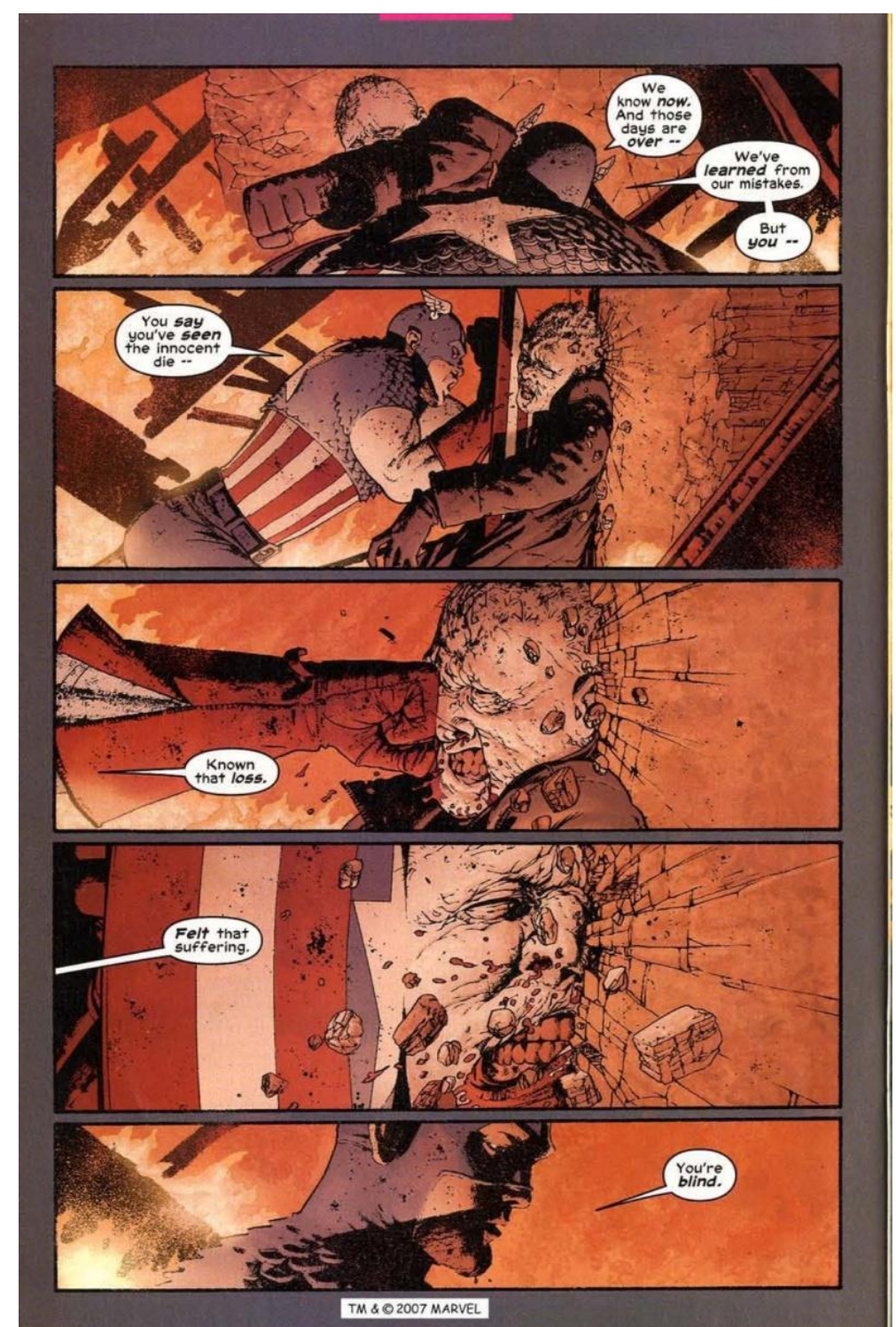

Figura 10. O Capitão defende a inocência de seu povo e diz ao inimigo que eles aprenderam com os erros. (Captain America nº, p.35 e 36, dez. 2002)

\footnotetext{
100 "You can't answer me, you mean. You played that game in too many places... The sun never set on your political chessboard... Your empire of blood." (tradução nossa) Captain America no\%, p.35, dez. 2002.

101 "My people never knew! We know now. And those days are over... We've learned from our mistakes. But you... You say you've seen the innocent day... Know that loss. Felt that suffering. You're blind. (tradução nossa) Captain America nº, p.35 a 37, dez. 2002.
} 
Aqui se evidencia que o Capitão América admite todas as acusações que o inimigo dirige contra os Estados Unidos, porém ele alega que seu povo "nunca soube" dessas ações de seu governo, muito menos das consequências. E classifica essas ações como "erros" que permitiram que os Estados Unidos aprendessem.

Não podemos especificar o quanto os cidadãos dos Estados Unidos conhecem ou desconhecem das ações imperialistas de seu país, entretanto, fica evidente que os atentados de 11 de setembro colocaram essas e outras questões em pauta, isso fica patente nos excertos de obras dos acadêmicos, expostos acima, e nessas HQs do Capitão América, pois as afirmações dos autores da HQ evidenciam sua preocupação em transmitir ao leitor mais do que apenas um lado da história, intencionam fazer com que o leitor reflita e também tome conhecimento sobre o outro lado da história de seu país.

Podemos afirmar que as HQs têm um caráter educacional, na medida em que procuram despertar em seus jovens leitores uma nova forma de pensar seu país. Há também uma mensagem ou um apelo evidente para que os cidadãos não se deixem dominar pelo ódio e acabem agindo de forma inconsequente, como o homem que atacou Samir, ou pior, se tornem pessoas como o Mestre dos terroristas que, devido a sua vida trágica, acabou sendo cegado pelo ódio e "[...] não tem visto nada além de sua própria dor. Seu próprio ódio... Ou você teria morrido antes de causar essa dor a outro homem... Qualquer homem, mulher ou criança. Você não é melhor do que os senhores da guerra que o criaram. Seja você de onde for. "102

A menção a esses "senhores da guerra" sugere que, por trás das guerras travadas pelos Estados Unidos e por outros países, existem pessoas que as controlam e, aparentemente, lucram com isso. Não temos como estabelecer que tipo de ideia os autores procuraram transmitir, porém essa referência a senhores da guerra pode estar ligada a teorias conspiratórias ou a uma crítica à indústria bélica norte-americana.

Isso fica evidente quando o Capitão levanta algumas questões, com relação à violação do espaço aéreo dos EUA - quando os terroristas usaram aviões para lançar bombas em Centerville - e quando suspeita que há algum tipo de ligação ilegal entre o exército e os terroristas que usam os mesmos dispositivos eletrônicos no pescoço, os CATtags, porém essas suspeitas acabam se revelando como uma falta de segurança dos Estados Unidos e um excesso de confiança do exército que acabou adquirindo diversos CATtags produzidos pelo

\footnotetext{
102 "You haven't seen anything but your own pain. Your own hate... Or you'd die before you'd cause another man this pain... any man, any woman, any child... You're no better than the warlords who created you. Wherever you're from." (tradução nossa) Captain America nº6, p.37, dez. 2002.
} 
Mestre dos terroristas, sem saber ou se preocupar com a origem deles, só queria dispor das mesmas tecnologias que o inimigo. Isso é demonstrado no seguinte diálogo entre Nick Fury e o Capitão sobre os CATtags e sua utilidade:

Capitão: O que são eles? Você sabe?

Fury: Eu sei o suficiente. Eles são uma vantagem que nossos inimigos tem, droga... Se nós não tivéssemos também.

Capitão: Eu sei tudo sobre essa sua vantagem. É de onde eu vim. Eu sou tecnologia militar. Mas isso não é tudo que sou. Você me confiou sua vida mais vezes do que posso contar. Olhe pra mim, Nick! Você ainda está aqui... Por que sou uma boa tecnologia? (o Capitão pega no casaco de Fury e retira um CATtag que ele usa no pescoço) Você tem brincado com essas coisas por muito tempo Coronel. Espero que ninguém use isso para brincar com você. Ache suas prioridades... Antes que eu volte. Te mando um cartão postal de Dresden. (e vai embora) ${ }^{103}$

Nessa parte, também há uma crítica ao que podemos chamar de "corrida armamentista" ou por tecnologias de guerra. O Capitão América é um exemplo vivo de uma tecnologia bélica que foi desenvolvida (no mundo da ficção) para que os Estados Unidos tivessem uma "vantagem" sobre os Nazistas na Segunda Guerra. E a HQ dá a entender que, deste então, os EUA tem investido em tecnologias que os deixem com maior poder que o inimigo ou, pelo menos, igual a estes. Com o tempo, isto gerou uma sensação de conforto e confiança, pois os EUA sempre conseguiram se manter à frente dos inimigos, com bombas atômicas, mísseis intercontinentais, armas químicas, jatos invisíveis a radares, etc. Esse excesso de confiança pode ser perigoso, provavelmente, nessa parte, os autores fazem uma alusão ao perigo que as armas de destruição em massa representam, seja nas mãos dos terroristas ou nas dos Estados Unidos.

Outra crítica que a HQ faz com relação a guerra é quando o Capitão chega a Dresden, na Alemanha. Durante a Segunda Guerra Mundial, a cidade foi completamente incendiada por um ataque das forças Aliadas, entre 13 e 14 de fevereiro de 1945. Em Dresden, o Capitão contempla a vista de uma parte da cidade e se lembra do passado, se lembra da cidade em chamas e pensa:

Você não entendeu o que fizemos aqui até o onze de setembro. Até então... Você diria que fizemos o que precisava ser feito... Para derrotar Hitler e os nazistas. Esmagar o Eixo. E seu mal. Mas, agora... O que você vê? Treze e

\footnotetext{
103 “Capitão: What are they? Do you know?/ Fury: I know enough. They're an edge that or enemies have, damn it... If we don't have them too./ Capitão: I know all about your edge. That's where I'm from. I am a military technology. But that's not all I am. You've trusted me your life more times than I can count. Look at me, Nick! You standing here... because I'm a good tech? You've been playing with toys too long Colonel. I hope nobody using them to play with you. Get your priorities straight...before I get back, Nick. I'll send you a postcard from Dresden." (tradução nossa) Captain America n5, p.25-26, nov. 2002.
} 
catorze de fevereiro de 1945. Estas pessoas não eram soldados, mas morreram. ${ }^{104}$

Na sequência, o Capitão relembra o sofrimento das pessoas que morreram queimadas em Dresden, o relato do sofrimento é acompanhado por imagens de corpos e objetos queimados; no fim da página o Capitão faz o seguinte comentário: "A história se repete. Como uma metralhadora. Um louco lança uma centelha... E o povo paga o preço."105

Nessa fala do personagem, não se pode determinar ao certo quem ele está criticando, mas há indícios que a crítica é endereçada aos Estados Unidos e aos terroristas, pois em meio a essa nova guerra, quem vai sofrer, de fato, é o povo, os inocentes. Os dois lados do conflito farão de tudo para derrotar o inimigo, assim como fizeram em Dresden e, no fim, milhares de pessoas não soldados terão morrido. A guerra é apresentada como um evento sem um sentido aparente, com ações justificáveis, porém, que só gera sofrimento e morte.

Essas críticas que a HQ apresenta ressaltam o caráter contestador e pacifista do personagem. Na última página da sexta edição, fica claro que, por mais que sejam justificáveis as ações dos terroristas, elas não são a melhor maneira de lutar contra os problemas que os Estados Unidos teriam provocado, e a Guerra ao Terror do presidente Bush também, por mais justificável que seja, não é apontada como a melhor maneira para reagir aos danos infligidos. A luta na qual os leitores deveriam se engajar é pela paz.

Eles sempre estarão conosco. Os Gengis Khans. Os Calígulas. Os Hitlers. Os monstros. Com sua sede de sangue, seus brinquedos assassinos... e suas mentiras. Mas, nós podemos parar essa onda de sangue. Desafiar as sombras. Defender o sonho. Nós, o povo. Todos têm a liberdade e o poder de lutar... pela paz. ${ }^{106}$

Na conclusão dessa série, fica claro que os autores procuraram incentivar e "convocar" o povo para lutar pela paz; existe uma mensagem pacifista bem evidente em todas as edições dessa HQ do Capitão América.

Esperança, críticas à suposta inocência dos EUA e o incentivo ao pacifismo são algumas das mensagens que essas HQs transmitem. Esse aspecto mais contestador e pacifista do Capitão pode ser associado a uma "humanização" do personagem em contraposição à

\footnotetext{
104 “You didn't understand what we'd done here. Until September the Eleventh. Before then... You would have said we were doing what we had to do... To defeat Hitler and the Nazis. Crush the Axe. And their evil. But now what you see? February Thirteenth and Fourteenth 1945. These people weren't soldiers. But they died." (tradução nossa) Captain America nº5, p.33 nov. 2002.

105 "History repeats itself. Like a machinegun. A madman lights the spark... And the people pay the price." (tradução nossa) Captain America n5, p.32 nov. 2002.

106 'They'll always with us. The Genghis Khans. The Caligulas. The Hitlers. The monsters. With their blood hunger and their murderous toys... And their lies. But we can stem the tide of blood. Defy the shadows. Defend the dream. We the people... We all have the freedom and the power to fight... for peace." (tradução nossa) Captain America no6, p.38 e 39, dez. 2002.
} 
"desumanização" de seus adversários que, ao longo da narrativa, são caracterizados como "monstros" movidos por um ódio cego, que não medem esforços para alcançar seus objetivos, ou melhor, sua vingança por atos que os EUA, de forma direta ou indireta, impuseram a eles ou seus países. Para uma melhor compreensão de como se constrói essa oposição entre herói e vilão, faremos, no próximo capítulo, uma análise de como isso ocorreu em determinados momentos da história do Capitão América. 


\section{CAPÍtUlo 2 \\ INIMIGOS}

\subsection{Um breve histórico das lutas do Capitão América e seus inimigos}

No decorrer de seus aproximados 73 anos de existência, o Capitão América combateu e, consequentemente, derrotou todos os inimigos que atacaram seu país. Quando foi criado em 1941, durante a Segunda Guerra Mundial, seus inimigos eram os países do Eixo (Alemanha, Itália e Japão). O nazismo e o autoritarismo dos países do Eixo representavam o grande "mal" que deveria ser combatido. Nas HQs, o Capitão enfrentava as mais diversas ameaças trazidas pelo Eixo, combatia soldados nazistas e japoneses, identificava e punia espiões que atuavam em seu país.

Muitas vezes, esses inimigos eram fisicamente apresentados como seres de aparência estranha, feios, alguns eram monstros com superpoderes enviados para destruir os Estados Unidos; o grande vilão nazista Caveira Vermelha ${ }^{107}$ [Red Skull] (Figura 1.), usava uma máscara para causar medo em seus inimigos. Japoneses também eram apresentados de formas estereotipadas e caricatas, eram pessoas de pele bem amarela, com dentes enormes, olhos muito fechados e algumas vezes representados como vampiros (ver figura 1. capa da edição $\mathrm{n}^{\circ} 13$ ) e com feições malignas ${ }^{108}$. Podemos afirmar que a intenção principal desse tipo de representação dos inimigos era despertar o medo nos leitores, que assim teriam mais motivos para temer e rejeitar os inimigos (quer dizer, os seres do Eixo), dando maior apoio à guerra, que era representada como uma luta do bem contra o mal. Além disso, essas HQs tinham um papel fundamental na definição de uma identidade territorial, na qual deve se deixar claro qual é a diferença entre "os valores do Capitão América (e dos Estados Unidos) em contraste ao dos Outros antiamericanos." (DITTMER, 2005, p.631, tradução nossa). ${ }^{109}$

\footnotetext{
${ }^{107}$ O Caveira Vermelha é o principal inimigo do Capitão América. O personagem tornou-se recorrente nas HQs do Capitão e, ao longo dos anos, ele passou por mudanças que o atualizaram para que ele continuasse sendo uma ameaça em diferentes contextos. Para maiores informações sobre as mudanças que este vilão sofreu e seu papel como antagonista nas HQs do Capitão, recomendamos a leitura da dissertação: "A história em quadrinhos enquanto representação política - Capitão América e Caveira Vermelha 1941/1999" de Shesmman Fernandes Barros de Melo (2011). Disponível em: 〈http://nou-rau.uem.br/nou-rau/document/?code=vtls000197084>

${ }^{108}$ Para maiores detalhes sobre essas representações dos inimigos, recomendamos a leitura do artigo "Madamen, Morons, and Monocles: the portrayal of the Nazis in Captain America" de John E. Moser. In: WEINER, Robert G. (org.) Captain America and the Struggle of the Superhero: critical essays. (2009)

109 "[...] with Captain America's (and thus, America's) values contrasted against his un-American Others." (DITTMER, 2005, p. 631).
} 

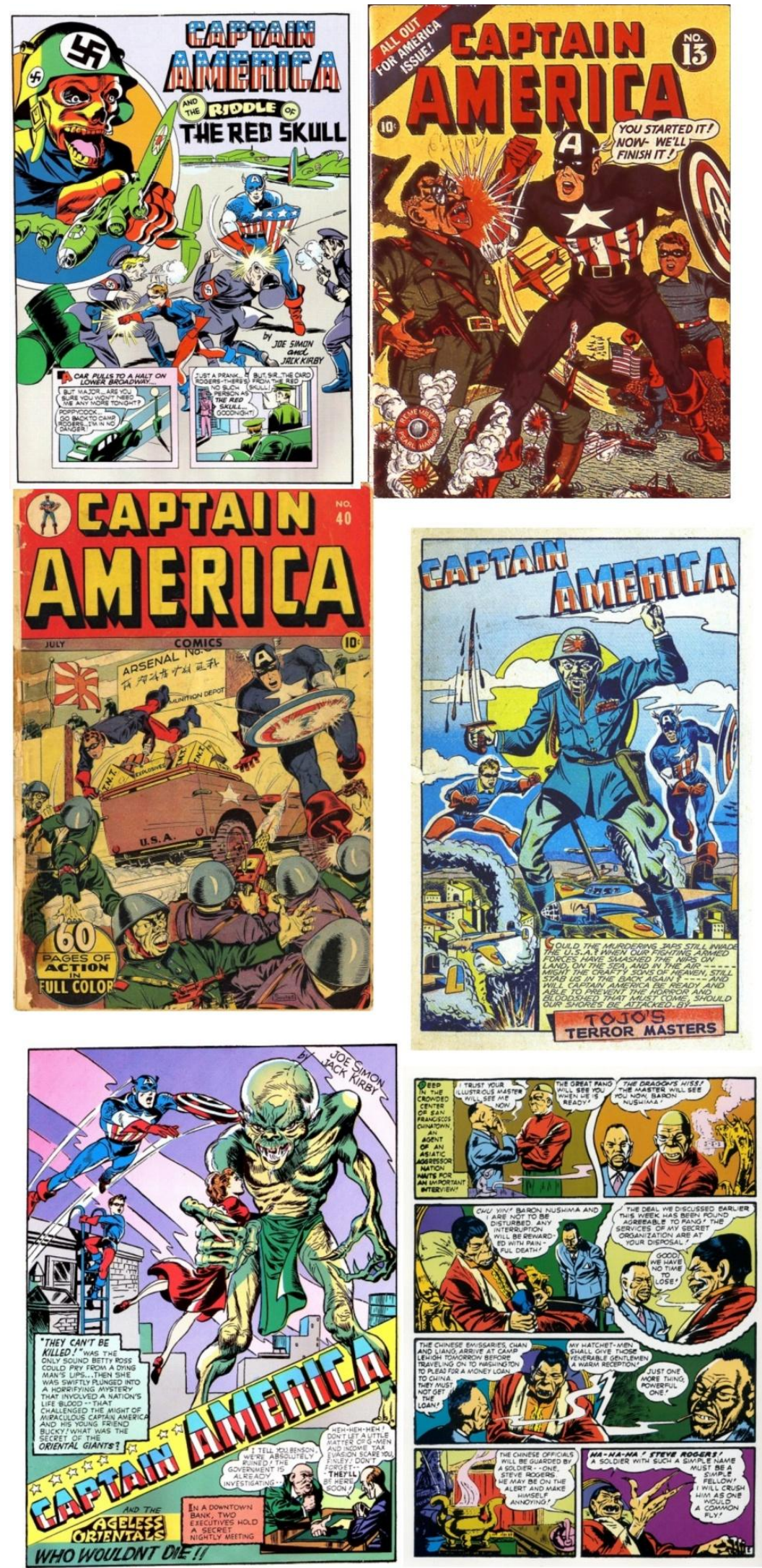

Figura 1. Alguns exemplos de como nazistas e japoneses eram fisicamente representados nas HQs do Capitão América na década de 1940. 
Essas histórias fizeram um enorme sucesso na época, pois tinham um forte apelo patriótico e propagandístico, estimulando jovens a se alistarem e participarem da maneira que podiam do esforço de guerra. Isto contribuiu para que o personagem se tornasse um ícone na luta contra as forças do Eixo; o Capitão América se popularizou como um herói que combatia nazistas e, com o fim da Guerra, tal identidade se tornou um problema para os editores do personagem. Afinal, a ameaça nazifascista já havia sido derrotada e não havia mais nenhuma outra suficientemente grande para o Capitão combater. Assim, após 1945, o personagem foi transformado em um herói que combatia crimes comuns e enfrentava seres com poderes sobrenaturais em histórias com conteúdo de terror. ${ }^{110}$

Essa reconfiguração do Capitão América não deu muito certo e sua revista acabou sendo cancelada, em meados de 1950 (na edição 75 de fevereiro). O personagem só voltou a ser publicado em maio de 1954, quando a editora Atlas Comics $^{111}$ relançou a revista, agora como "Captain America... Commie Smasher" [Capitão América... Esmagador de Comunistas]. O título da publicação é o suficiente para sabermos quem eram os inimigos que ameaçavam os Estados Unidos nesse novo momento. No interior das HQs, vemos o Capitão e seu jovem parceiro Bucky combatendo as mais diversas ameaças comunistas, mas seus alvos principais eram espiões e traidores que teimavam em se infiltrar na sociedade norteamericana, num esforço para destruir seus valores morais e escravizar todos com seus ideais.

Nessa fase, mantiveram-se os mesmos estereótipos que foram usados para representar os inimigos durante a Segunda Guerra Mundial. Os comunistas eram fisicamente caracterizados como feios. Os chineses e coreanos comunistas eram representados da mesma maneira que os japoneses na Segunda Guerra; monstros comunistas e garras gigantes eram usados para despertar o medo nos leitores (Figura 2.).

Nesse período, foram publicadas apenas três edições do personagem $(76,77$ e 78$)$ e o conteúdo delas pode ser associado a toda a paranoia desencadeada pelo senador Joseph McCarthy ${ }^{112}$ e seus seguidores. McCarthy pode ser considerado uma das figuras mais polêmicas desse período inicial da Guerra Fria, sua atuação política foi marcada por uma incessante "caça aos comunistas", que estariam infiltrados na sociedade norte-americana e muitos deles, inclusive, fariam parte do governo. Ele chegou a pronunciar "um discurso, no

\footnotetext{
${ }^{110}$ Entre outubro de 1949 e fevereiro de 1950 a revista do personagem ganhou o subtítulo Captain America's Weird Tales [Contos Estranhos do Capitão América]. E apresentava histórias com conteúdo de terror.

${ }^{111}$ Nome que a editora Marvel Comics usava na época.

112 Ele era filiado ao partido Republicano e foi senador pelo estado de Winsconsin, de 1947 a 1957. McCarthy morreu em 2 de maio de 1957, aos 48 anos, devido a problemas hepáticos causados por abuso de álcool. Essas informações foram extraídas do site: "Joseph McCarthy: Biography - Appleton Public Library". Disponível em: < http://www.apl.org/book/export/html/1012> Acesso em: 10/03/2014.
} 
qual atribuiu a supostos comunistas infiltrados no Departamento de Estado a culpa pelos reveses da política exterior dos Estados Unidos." (BANDEIRA, 2005, p.168).
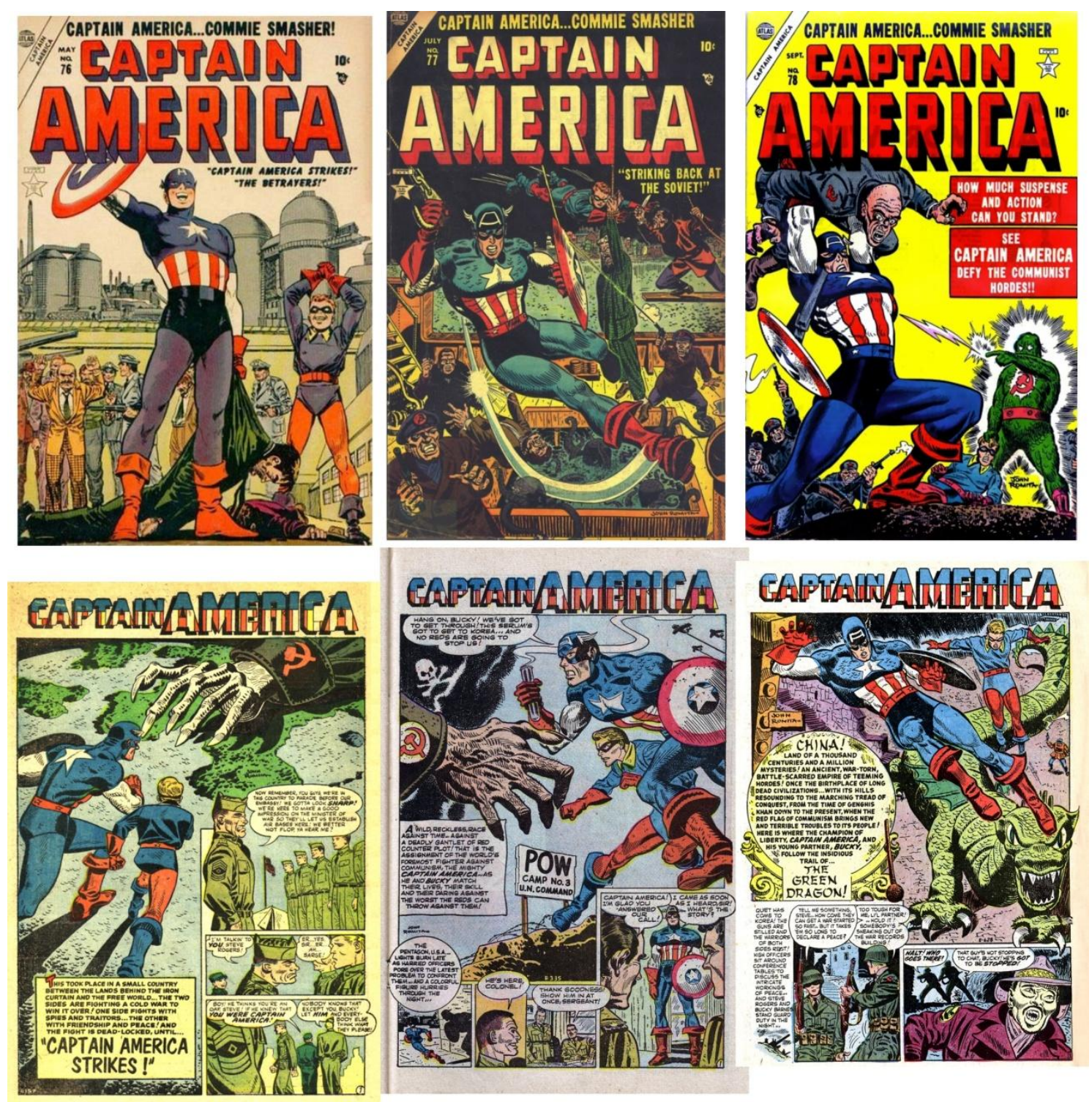

Figura 2. Acima as capas das edições de 1954 do Capitão América, abaixo algumas páginas que dão uma ideia de como os comunistas foram representados nessas HQs.

A paranoia anticomunista de McCarthy não durou muito tempo, e nem essas HQs do Capitão América, a revista do personagem foi cancelada em setembro de 1954 devido a suas baixas vendas. Outra razão para o fracasso da publicação é uma mudança gradativa que ocorreu no público consumidor de quadrinhos nos EUA, de acordo com Hayton e Albright (2009)

Esse retorno do super-herói falhou porque a consciência da audiencia já havia superado modelo simplista da editora de super-herói propaganda. A versão do Capitão América da era McCarthy viria a ser rejeitada pela 
Marvel como uma expressão legítima de ideais americanos. (p.17, tradução nossa) ${ }^{113}$

Vale destacar que o Capitão América desses períodos era apresentado como um soldado que cumpria as ordens de seus superiores sem as questionar. Fazia de tudo para derrotar seus inimigos, não hesitava em usar tortura ${ }^{114}$ para conseguir informações ou matar inimigos, se fosse o caso ${ }^{115}$.

A fase anticomunista extrema do Capitão América foi completamente deixada de lado e as ações do personagem durante a Segunda Guerra foram gradativamente reelaboradas e revistas a partir de 1964, quando o escritor Stan Lee ${ }^{116}$ trouxe o personagem de volta à vida como membro da equipe de super-heróis Os Vingadores ${ }^{117}$ [The Avengers]. Lee inventou uma nova história para o personagem, e na narrativa mostrou que o Capitão América havia sofrido um acidente antes do fim da Segunda Guerra e acabou sendo congelado em um pedaço de iceberg; posteriormente, Os Vingadores o encontraram e o descongelaram. O herói teria conseguido sobreviver por tantos anos devido ao soro de supersoldado que foi injetado em suas veias para lhe dar superpoderes.

Stan Lee introduziu significativas mudanças no personagem que, ao ser ressuscitado, apresentava-se desorientado e com sentimentos e valores que não correspondiam à época em que havia ressurgido, porém o personagem, a princípio, não perdeu suas características propagandistas. Um bom exemplo disso está na revista "Tales of suspense”, número 61, de janeiro de 1965, contendo histórias do Homem de Ferro e do Capitão América. Ela apresenta uma história do Capitão América intitulada "The strength of the Sumo" ${ }^{118}$ [O poder do sumô]. Em linhas gerais, a HQ mostra o Capitão América em uma missão de resgate num campo de

\footnotetext{
113 "This superhero revival failed because the awareness of the intended audience had outgrown the publisher's simplistic superhero propaganda model. The McCarthy era version of Captain America would be withdrawn by Marvel as a legitimate expression of American ideals.” (HAYTON e ALBRIGHT, 2009, p.17).

${ }^{114}$ Um exemplo disso é encontrado logo na primeira edição de 1941 quando, após derrotar um inimigo nazista, o Capitão tenta extrair informações apertando a garganta do inimigo com força (p. 21 da edição original de 1941).

${ }^{115}$ Quanto a matar inimigos existem muitos exemplos, mas um que vale destaque pela frieza com que o personagem age está na edição 46 de 1954 do Capitão esmagador de comunistas, na qual o herói deixa um espião comunista morrer queimado em um incêndio e diz: "Ele morreu do jeito que queria que o mundo livre morresse...em chamas!" [He died the way he wanted free world die...in flames] (p.09).

${ }^{116}$ Stan Lee, ou Stanley Martin Lieber, na época, era um dos principais escritores e criador de importantes personagens da Marvel Comics (como o Homem-Aranha, Hulk, Homem de Ferro, entre outros). Além disso, Stan Lee é conhecido nos meios dos quadrinhos por ter promovido uma mudança na forma de escrever histórias de super-heróis ao introduzir sentimentos, angústias e problemas cotidianos e sociais nas aventuras de seres superpoderosos. Para maiores informações sobre a Marvel Comics e as mudanças que Lee promoveu na editora recomendamos a leitura de "Secret Identity Crisis: Comic Books \& Unmasking of Cold War America" de Matthew J. Costello (2009), e "Stan Lee: o reinventor dos super-heróis" de Roberto Guedes (2012)

${ }^{117}$ Grupo de super-heróis criado por Stan Lee e Jack Kirby, apareceram pela primeira vez na revista "The Avengers", em setembro de 1963. O Capitão América foi descongelado e entrou para a equipe em março de 1964 na quarta edição da revista The Avengers.

${ }^{118}$ Essa história foi escrita por Stan Lee e desenhada por Jack Kirby.
} 
batalha no Vietnã. Ao longo de sua missão, o Capitão enfrenta vários soldados comunistas, com o único objetivo de resgatar o piloto de helicóptero, Jim Baker, irmão de um colega do Capitão, durante a Segunda Guerra.

Nessa história o Capitão América é caracterizado como um homem que tem uma nobre missão a ser cumprida e esta não tem um caráter de ataque, pois como mostra a primeira página desta história, o Capitão foi ao Vietnã para dialogar com os sequestradores de seu amigo e conseguir sua libertação por meios pacíficos, não para participar ativamente do conflito.

Já os soldados comunistas são representados como homens rudes e agressivos - em alguns momentos suas feições estereotipadas pouco lembram as de um ser humano -, que estão constantemente tentando provar sua superioridade ou testar a força do Capitão América, colocando-o em combate contra soldados superfortes e contra um general lutador de sumô.

A intervenção norte-americana na Guerra do Vietnã é apresentada como um resgate e em um diálogo entre o Capitão e Jim Baker, próximo do fim da HQ, há uma evidente propaganda pró-guerra, a conversa é a seguinte: Jim Baker - "Mas, todo o mundo livre precisa de você, Capitão...!" E o Capitão América responde: "Ele precisa de você também, filho! Ele precisa de todos nós!" 119 Esse breve diálogo é um convite aos leitores para se juntarem ao Capitão América e aos Estados Unidos na luta do chamado "mundo livre" contra o comunismo.

No decorrer do tempo, essa fase mais propagandística do Capitão América vai dando lugar a um personagem mais complexo, um reflexo das mudanças que estavam ocorrendo no período. Para o governo norte-americano, os anos de 1960 e 1970 foram marcados por grandes desafios políticos, tanto externos (a Guerra do Vietnã e a Guerra Fria de modo geral), quanto internos. Internamente, ocorreu a eclosão de uma série de movimentos por direitos civis - de negros, mulheres, gays e de outras "minorias" excluídas das políticas oficiais do governo - que exigiam, não só seus diretos, mas também o fim da Guerra do Vietnã.

Com relação a isso, o escritor Stan Lee se mostrou bem atento às demandas da sociedade norte-americana do período; em 1969, na edição 117 da revista Captain America, ele introduziu um novo personagem, o herói afro-americano Falcão (The Falcon), que se tornou o novo parceiro do Capitão América na luta contra todo o tipo de ameaça durante

\footnotetext{
${ }^{119} \mathrm{O}$ diálogo original na ordem que aparece é o seguinte: "But the entire free world needs you, Cap...!"/“It needs you too, son! It needs all of us!" (tradução nossa) Tales of Suspense/Captain America no 61, 1965, p. 05. (grifo no original).
} 
muitos anos ${ }^{120}$. A inclusão do personagem buscava estabelecer um diálogo com as reivindicações dos movimentos negros.

Stan Lee também usou o Capitão América para divulgar sua visão sobre as manifestações e rebeliões que ocorreram no período, principalmente, as de 1968. Isto ocorreu na edição 122 da revista Captain America de fevereiro de 1970, que contém a história intitulada "The Sting of The Scorpion" [O ferrão do Escorpião]. Ela começa com o Capitão América vagando por uma rua de Nova York, refletindo sobre sua vida dedicada a lutar por justiça e liberdade, se indagando sobre quando essa batalha terá um fim. Ele questiona sua importância no mundo atual, seu papel como defensor da democracia, que valor têm seus ideais em um mundo onde "Agora há aqueles que desprezam o amor pela bandeira... o amor pelo país! Aqueles que Patriotismo é apenas uma palavra fora de moda!"121

O herói segue se lamentando, comparando-se a um dinossauro, a um homem préhistórico vivendo num tempo que não é o seu, um tempo cheio de "rebeldes" e "dissidentes" onde a moda não é defender o "stablishment", mas, sim, destruí-lo. "E, em um mundo cheio de injustiça, ganância e guerras sem fim... quem pode dizer que os rebeldes estão errados?"122. Suas lamentações terminam com a seguinte frase: "Deveria ter lutado menos $e$ questionado mais!" 123 (Figura 3.)

Além disso, o Capitão se pergunta como combater um mal que assume várias formas, que não é claramente definido e que, muitas vezes, está ligado ao establishment. Ele admite que os "rebeldes" são os únicos que têm coragem de lutar contra esse mal e, como um herói que pertence ao establishment, ele não pode derrubá-lo. Argumenta que esse mesmo establishment deu aos "rebeldes" um Martin Luther King, um Tolkien, um McLunan, e dois irmãos chamados Kennedy, e este também não tem a pretensão de ser perfeito. E a saída é que todos aprendam a conviver e amar uns aos outros, pois o "Amor! É uma coisa que nenhuma geração pode reivindicar como monopólio" ${ }^{\prime 24}$.

\footnotetext{
${ }^{120}$ Até a edição 222 da revista Captain America de 1978, do ano de 1971 até meados de 1978, a presença do Falcão tornou-se tão marcante que o título da revista do Capitão foi alterado para Captain America and The Falcon.

121 "There are those who scorn Love of flag...love of country! Those to whom patriotism is just a square, outmoded word!" (tradução nossa) Captain America n ${ }^{\circ}$ 122, p.02, 1970.

122 "And in a world rife with injustice, greed and endless war. Who's to say the rebels are wrong?" (tradução nossa, grifo no original) Captain America $\mathrm{n}^{\mathrm{o}} 122, \mathrm{p} .03,1970$.

123 "I Should battled less....and questioned more!" (tradução nossa) Captain America no 122, p.03, 1970.

124 "Love! That one thing no generation can claim a monopoly on!" (tradução nossa) Captain America n ${ }^{\circ} 122$, p.05, 1970.
} 

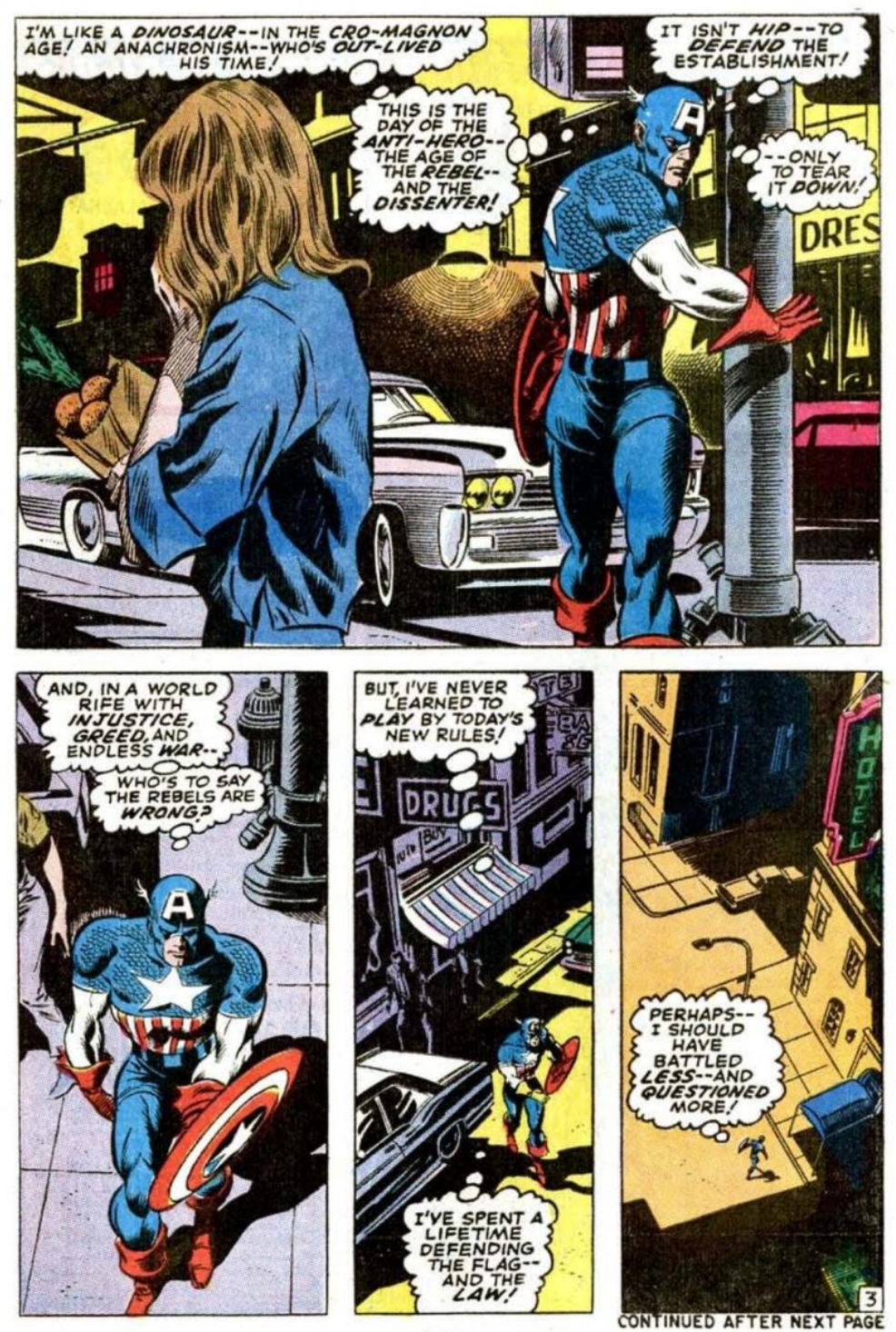

Figura 3. O Capitão América dos anos 70 apresenta-se confuso e questiona sua utilidade num mundo onde os valores que ele defende, aparentemente, estão fora de moda. (Captain America $\mathrm{n}^{\circ}$ 122, p.03, 1970)

Nos trechos citados, percebemos que o Capitão América, mesmo tendo dúvidas sobre o establishment que ele defende, não acredita que a solução seja destruí-lo, pois ainda acredita nele; talvez, acredite que ele possa ser mudado sem uma revolução, ou sem conflitos maiores. Vemos também um deslocamento de um problema que é de ordem social e política para um problema moral e de conflito de gerações, onde a solução recomendada seria o amor e o respeito entre todos.

As mudanças que Lee fez no personagem o transformaram em um representante de uma tendência político cultural/religiosa que Robert Jewett (1973 apud WICKS, Robert ${ }^{125}$,

\footnotetext{
${ }^{125}$ WICKS, Robert. Sentinels of Liberty: Captain America, his doubles, and the dilemma of American identity. Wilkes Honors College of Florida Atlantic University, 2009. Disponível em: < http://fau.digital.flvc.org/islandora/object/fau\%3A1379> Acesso em: 10/03/2014.
} 
2009, p.02-03) chama de "Realismo Profético" [Prophetic Realism], caracterizada por um comprometimento com a "diplomacia, justiça imparcial, e com a compreensão". Esta existe em oposição à outra tendência que Jewett nomeia de "Nacionalismo Zeloso" [Zealous Nationalism], “que busca redimir a América por meio da destruição do mau. É caracterizado por uma visão preto-e-branco do mundo na qual os inimigos dos Estados Unidos devem ser erradicados e obliterados." ${ }^{126}$ Dentro desta perspectiva, podemos dizer que as configurações do Capitão América da Segunda Guerra Mundial e do período macartista se enquadram na definição de Nacionalismo Zeloso.

De acordo com Robert Wicks (2009), essas tendências são constantes em diferentes momentos do personagem. Cada artista que já trabalhou com o personagem deu ênfase em algumas dessas tendências, porém desde os anos 60, "a Marvel tem consistentemente retratado o Capitão como a incorporação de realismo profético progressivo."(p.04, tradução nossa $)^{127}$. Para comprovar sua teoria, Wicks analisa diversas HQs do Capitão e ressalta que em muitos momentos, os autores criaram versões alternativas do personagem.

Um exemplo disso são as HQs do Capitão América produzidas entre novembro e dezembro de 1972 por Esteve Englehart (roteiro) e Sal Buscema (desenhos). Como Stan Lee, ao ressuscitar o Capitão não se deu ao trabalho de explicar como era possível ele ter ficado quase 20 anos congelado e, ao mesmo tempo, ter combatido criminosos e comunistas entre 1945 e 1954, Englehart teve que desenvolver uma explicação para isso, assim ele estabeleceu que o "o Esmagador de Comunistas como um falso Capitão América que surgiu na ausência do verdadeiro herói [...]." (HAYTON e ALBRIGHT, 2009, p.17, tradução nossa). ${ }^{128}$

Nas HQs, Englehart traz o falso Capitão América de volta e faz com que os dois travem uma batalha mortal, que Wicks interpreta como uma luta entre as duas tendências do personagem. O mesmo Wicks cita outros momentos nos quais os autores das HQs do personagem procuraram colocá-lo em confronto com outras "duplicatas". E, na maioria das vezes - mesmo perdendo sua identidade por algum tempo ${ }^{129}$ - , Steve Rogers, o "verdadeiro" Capitão América, acabava vencedor.

\footnotetext{
126 "Zealous nationalism seeks to redeem America through the destruction of the wicked. It is characterized by a black-and-white view of the world in which the enemies of America need to be rooted out and obliterated." (WICKS, 2009, p.02-03).

127 “[...] Marvel has consistently portrayed Cap as the embodiment of progressive prophetic realism." (WICKS, 2009 , p.04).

128 "Writer Steve Engleheart subsequently formally dismissed the Commie Smasher as a phony Captain America, who arose in the absence of the real hero [...]" (HAYTON e ALBRIGHT, 2009, p.17).

${ }^{129}$ Isso ocorreu nas HQs entre 1987 e 1989 quando Steve Rogers foi obrigado a deixar de ser o Capitão América e foi substituído por John Walker, um soldado mais leal e menos questionador. Essa fase do personagem foi escrita por Mark Gruenwald que contou com o trabalho de diversos desenhistas. Uma boa análise dessa fase do personagem pode ser encontrada no trabalho de Robert Wicks, citado acima.
} 
Essa proposta de análise de Wicks nos permite compreender como a indústria de quadrinhos encontrou soluções para atualizar o Capitão América de acordo com as tendências políticas que se alternavam. E, com isso, contribuiu para a solidificação na figura de Steve Rogers de uma imagem mais "benevolente" e tolerante dos Estados Unidos. Uma visão idealizada que, muitas vezes, não correspondia às demandas do público consumidor norteamericano. Assim, visando a atender às demandas do mercado, a editora não mudava a essência de Steve Rogers, mas o deixava de lado, e o substituía por outro Capitão América que estivesse mais ao gosto do público. Entretanto, o original sempre voltava e colocava as coisas no seu lugar, um possível sinal das preferências políticas da editora e da permanência de uma determinada visão idealizada dos Estados Unidos, representada pelo Capitão América.

Esta apresentação do histórico do personagem, em relação aos inimigos, teve como objetivo situar o leitor com relação a algumas das principais mudanças pelas quais o Capitão América passou e como isso contribuiu para que ele se tornasse um símbolo do que o roteirista John Ney Rieber considera o “melhor da América” (2002, p.89). O que é esse “melhor”, após 11 de setembro, e qual é o papel dos inimigos nessa construção identitária dos Estados Unidos? Como o Capitão lida com seus inimigos é o que define, em parte, o caráter do personagem e, consequentemente, de seu povo.

Assim, agora, voltaremos à análise de nossas fontes primarias para tentarmos definir como se dá a interação entre herói e inimigo, e que tipo de identidade os autores dessas HQs almejam construir para o Capitão América e os Estados Unidos.

\subsection{Criando um inimigo}

Os inimigos são elementos indispensáveis às narrativas heroicas; de acordo com Christopher Vogler (1998) esses inimigos constituem o arquétipo Sombra que

representa a energia do lado obscuro, os aspectos não-expressos, irrealizados ou rejeitados de alguma coisa. Muitas vezes, é onde moram os monstros reprimidos de nosso mundo interior. As Sombras podem ser todas as coisas que não gostamos em nós mesmos, todos os segredos obscuros que não queremos admitir, nem para nós mesmos. As características que renunciamos, ou que tentamos arrancar, ainda sobrevivem e agem no mundo das Sombras do inconsciente. A Sombra também pode abrigar qualidades positivas que estão ocultas ou que rejeitamos por algum motivo. (p.83, grifo nosso)

Os inimigos do Capitão América que Rieber e Cassaday idealizaram apresentam as características destacadas acima. Os dois principais antagonistas do herói nas HQs - Faysal Al-Tariq e o Mestre dos terroristas - são manifestações de Sombras ligadas ao lado obscuro 
das ações internacionais dos Estados Unidos, através de suas ações e discursos trazem à tona fatos ignorados pelo Capitão América e por grande parte dos cidadãos dos EUA. Ao confrontar-se com esses antagonistas, o Capitão América toma conhecimento de tais fatos e isso permite que ele reflita sobre o papel que seu país tem desempenhado ao longo do século XX. O herói também reconhece que essas Sombras fazem parte da constituição da identidade de seu país. Ignorá-las, nesse momento traumático, talvez não seja a melhor maneira para lidar com e superar a tragédia de 11 de setembro.

Como vimos no primeiro capítulo, Al-Tariq sequestrou a população de Centerville com a intenção de puni-los por abrigarem em sua aparentemente inocente e pacífica cidade uma fábrica de bombas - possivelmente, usadas pelo exército americano em suas intervenções no exterior. Além de revelar esse fato, Al-Tariq também expõe ao herói as consequências das ações dos EUA, isso ocorre quando o Capitão é forçado a lutar contra os jovens mutilados devido a explosões de minas terrestres. E quando o mesmo Al-Tariq expressa suas opiniões sobre os Estados Unidos, fica evidente que o principal motivador da ação desse inimigo é o desejo de vingar a morte de seus compatriotas, vítimas de ataques norte-americanos. Suas ações são orientadas por esse sentimento de vingança e seus atos são a expressão de uma concepção de justiça.

Os autores procuram deixar claro que o senso de justiça de Al-Tariq é diferente daquele do Capitão América: o primeiro acredita que deve infringir aos cidadãos dos Estados Unidos o mesmo tipo de sofrimento ao qual seu povo foi exposto; já o Capitão defende a vida de seu povo e também de seus inimigos. Desta maneira, pode-se considerar que o senso de justiça do Capitão América é mais amplo e imparcial, e a pena de morte não é uma alternativa adequada aos olhos do herói, porém quando acredita ter sido responsável pela morte de AlTariq, o Capitão assume toda a culpa, pois seu senso de justiça, diferentemente do de seu oponente, não permite que outros sofram por causa de seus atos "Eu matei Faysal Al-Tariq. A responsabilidade... a falha é minha."

De acordo com John Ney Rieber, sua intenção ao construir essas situações nas HQs era expor o Capitão América a um "conflito moral" parecido com o que estava sendo divulgado nos jornais sobre “o que faríamos se pegássemos Osama bin Laden?” e Rieber estabeleceu algumas questões com as quais o personagem teria que lidar:

Há alguém que vai querer pegá-lo vivo? E se você fosse o primeiro soldado no bunker e tivesse que tirá-lo de lá, o que você faz? E se você fosse o primeiro soldado no bunker e sua família tivesse morrido quando as Torres

\footnotetext{
130 "I killed Faysal Al-Tariq. The responsibility ... the failure is mine." (tradução nossa) Captain America nº4, p.04, set. 2002.
} 
caíram, o que você faz? E se você fosse uma pessoa que sempre acreditou que todos tem o direito a um julgamento - o que você faz? (RIEBER, 2002, p.89, tradução nossa) ${ }^{131}$

Nas HQs, o inimigo apresentado não é Osama bin Laden, são versões fictícias e genéricas de terroristas islâmicos, que foram construídos para expor ao herói questões que façam refletir. E, a partir disto, o Capitão América deve escolher a melhor maneira de combatê-los. A alternativa indicada e defendida pelo herói apresenta restrições ao uso de força letal, matar o inimigo só quando não houver alternativa.

O Capitão América apresenta-se como um defensor da vida, enquanto seus inimigos defendem a morte. Este é outro traço característico da construção de antagonistas nas narrativas heroicas, segundo Vogler: "Os vilões e inimigos, dedicam-se à morte, à destruição ou à derrota do herói." (1998, p.83). Nas HQs, os inimigos não querem só a morte do herói, eles ambicionam causar o maior número possível de mortes, desejam destruir os Estados Unidos e tudo o que o país representa. Essa ideia fica evidente na segunda edição da série quando um dos homens, sob o comando de Al-Tariq, força a repórter Jessica Seldon a ler um comunicado endereçado ao Capitão e a todos nos Estados Unidos, que diz: "Nós estamos aqui esperando pelo Capitão América... o homem mundialmente conhecido como o defensor do Sonho Americano para... morrer. Para pagar com seu sangue pelos crimes de uma nação de sangue.", 132

Al-Tariq e seus homens são os primeiros antagonistas a apresentarem suas visões sobre os Estados Unidos; o confronto entre esses inimigos e o Capitão América é permeado por questionamentos sobre as guerras e suas consequências. O herói reconhece que muitas das coisas que ele tem que fazer no campo de batalha não são de seu agrado, entretanto, como um bom soldado ele não deixa de lutar, pois as vidas dos cidadãos de Centerville estão em suas mãos. Os inimigos não lhe deram outra opção, não há linha de diálogo nem negociação para libertar os reféns, há somente violência de ambos os lados. No entanto, os inimigos apresentam-se como mais violentos, eles são caracterizados como se não sentissem remorso por seus atos de violência. Agridem e matam inocentes sem demonstrar nenhum tipo de remorso e arrependimento.

\footnotetext{
131 "We're seeing reflections in the news: what we will do if we catch Osama bin Laden. [...] Is anyone going to want get him alive? If you're the first soldier in the bunker and you have to drop on him, what do you do? If you're the first soldier in the bunker and your family died when the Towers went down, what do you do? If you're someone who has always believed that everyone has the right to a trial - what do you do?" RIEBER, John Ney. In: The Comics Journal, 241, fevereiro de 2002.

132 "We're here waiting for Capitain America. The man know throughout the world as the defender of the American Dream. To... To die. To pay with his blood for crimes of a nation of blood" (tradução nossa) Captain America no2, p.13, jul. 2002.
} 
A violência do Capitão América é caracterizada como uma reação defensiva, os inimigos atacaram primeiro, agrediram os cidadãos de Centerville e estão pondo a vida deles em risco. Jason Dittmer (2005) afirma que essa ação defensiva do Capitão América contribui para uma determinada narrativa que os Estados Unidos fazem de si mesmos:

\begin{abstract}
De fato, uma das ideias da narrativa geopolítica americana é a de que os Estados Unidos só agem em nome da segurança, não em nome de seu império. [...] o Capitão América é provido de uma arma única entre os heróis de histórias em quadrinhos: um escudo. Isto é um indicativo da associação dele com o roteiro geopolítico dos Estados Unidos. A maioria dos super-heróis que usam acessórios portam glamourosas armas ofensivas; o Capitão América tem um não tão glamouroso (e patrioticamente colorido) escudo. Embora o Capitão América tenha se tornado muito bom em lançar seu escudo como uma arma ofensiva (que sempre volta diretamente para suas mãos), é importante para a narrativa americana que ele incorpore uma postura defensiva em vez de ofensiva. (2005, p.630 tradução nossa) $)^{133}$
\end{abstract}

A arma e a postura defensiva do Capitão América nas HQs refletem um dos aspectos do já mencionado "mito da moralidade", no qual

Dizem-nos que os Estados Unidos sempre tentaram evitar a guerra; quando forçados a seguir a via militar, raramente o fizeram movidos por desejos de ganho ou glória. Que, pelo contrário, suas guerras foram empreendidas em nome de princípios elevados, como liberdade dos mares e direito à autodeterminação, e para conter agressões. (LENS, 2003, p.21)

Partindo disto, fica evidente que todas as ações violentas do personagem têm como motivação "conter as agressões" impostas a seu povo. Sua ação está mais do que justificada, além disso, a preocupação do herói em preservar a vida de seus inimigos torna seus atos ainda mais moralmente justos. Isso é demonstrado quando o Capitão arrisca-se para salvar um de seus jovens inimigos da explosão suicida, nesse momento, ocorre uma mudança de perspectiva, o jovem agressor, ao deparar-se com a ação altruísta de quem ele considerava um inimigo, percebe que o Capitão não é isso e que Al-Tariq mentiu para eles.

Nessa parte da HQ os autores fornecem indícios de como eles interpretam e idealizam as ações dos Estados Unidos perante seus inimigos. Em primeiro lugar, eles transmitem a ideia de que os Estados Unidos, na figura do Capitão, devem esforçar-se para compreender aqueles que são descritos como inimigos, pois eles podem estar sendo manipulados por

\footnotetext{
133 "Furthermore, Captain America contributes to the American geopolitical narrative by being ultimately defensive in nature. Indeed, a conceit of the American geopolitical narrative is that America only acts in the name of security, not empire. [...] Captain America is provided with a weapon unique among comic book heroes: a shield. This event is indicative of his association with the American geopolitical script. Most superheroes who use props carry glamorous offensive weapons; Captain America has a rather unglamorous (yet patriotically colored) shield. While Captain America has become quite good at throwing his shield as an offensive weapon (and always managing to have it bounce right back to him), it is important for the narrative of America that he embodies defense rather than offense." (DITTMER, 2005, p.630).
} 
líderes mentirosos como Al-Tariq; em segundo lugar, o Capitão tem a missão de revelar quem de fato são os inimigos, para seu povo e também para os próprios inimigos. Os quadrinhos também transmitem a ideia de que existe uma forte manipulação ideológica, Al-Tariq, aparentemente, se aproveitou da tragédia pessoal de cada garoto para usá-los como armas contra os Estados Unidos, teria enganado os jovens para servirem como instrumentos de seu ódio vingativo.

Dentro de suas possibilidades, as HQs procuram lidar com a complexidade das relações que existem entre os Estados Unidos e seus inimigos: por um lado, os autores humanizam os inimigos ao expor suas motivações e tragédias pessoais; por outro, mostram quão desumanos esses inimigos podem ser, e eles são frequentemente adjetivados como "monstros", mas essa caracterização não é física como ocorria no passado. Quando aparecem personagens com alguma deformidade física - como os garotos mutilados e o Mestre dos terroristas, que tem o rosto desfigurado por queimaduras -, estas são apresentadas como marcas das ações dos Estados Unidos que os inimigos carregam. A falta de humanidade dos inimigos é determinada pela maneira como agem.

Na quinta edição da série, o Capitão luta contra os terroristas que o atacaram em uma represa e, em meio ao combate, um dos soldados inimigos atira em seus colegas com uma metralhadora até descarregar a arma. Sem balas, ele tenta pegar uma arma que está sob o corpo de um de seus colegas, quando o Capitão América aparece e diz: "Ela pode estar carregada. Mas, isto não fará de você um soldado" ${ }^{\prime 134}$, a isso se segue um diálogo de duas páginas (Figura 4.) entre o Capitão e o terrorista, o conteúdo é o seguinte:

Capitão: Você assassinou dois homens que estavam sob seu comando.

Terrorista: (apenas ri) Hahaha

Capitão: Não há nada para rir. Aqueles homens estão mortos.

Terrorista: A morte ataca nossos inimigos. Somos assassinos (enquanto diz isso segura um dos CATtags). Não podemos morrer. Seu mundo está acabado. Todo o poder repousa no interior dos muros de Alamut.

Capitão: A fortaleza dos Assassinos medievais? Os mongóis a arrasaram no século treze. São ruínas.

Terrorista: Hahaha. Suas nações, suas leis... Elas são as ruínas. Sujeira sob os pés do mestre. E vocês Americanos... Agora hasteiam sua bandeira tão alto. Mas, sua "liberdade"... Sua preciosa "liberdade" ... Você gostaria de trocar tudo por isto. A liberdade da morte. Esta é liberdade que importa... (ao dizer isso o inimigo morre). ${ }^{135}$

\footnotetext{
134 "It may be loaded. But it won’t make you a soldier." (tradução nossa) Captain America n5, p.18, out. 2002.

135 Capitão: "You just butchered two men who were under your command."/ Terrorista: (...). / Capitão: "That's nothing to laugh about. Those men are dead."/ Terrorista: "Death strikes our enemies. We are assassins. We cannot die. Your world is over. All powers lies within the walls of Alamut."/ Capitão: "The fortress of medieval assassins? The Mongols razed it in the thirteen century. It's a ruin."/ Terrorista: "Your nations, your laws are the ruins. Dirt beneath the Master's feet. And you Americans... You fly your flag so high, now. But
} 

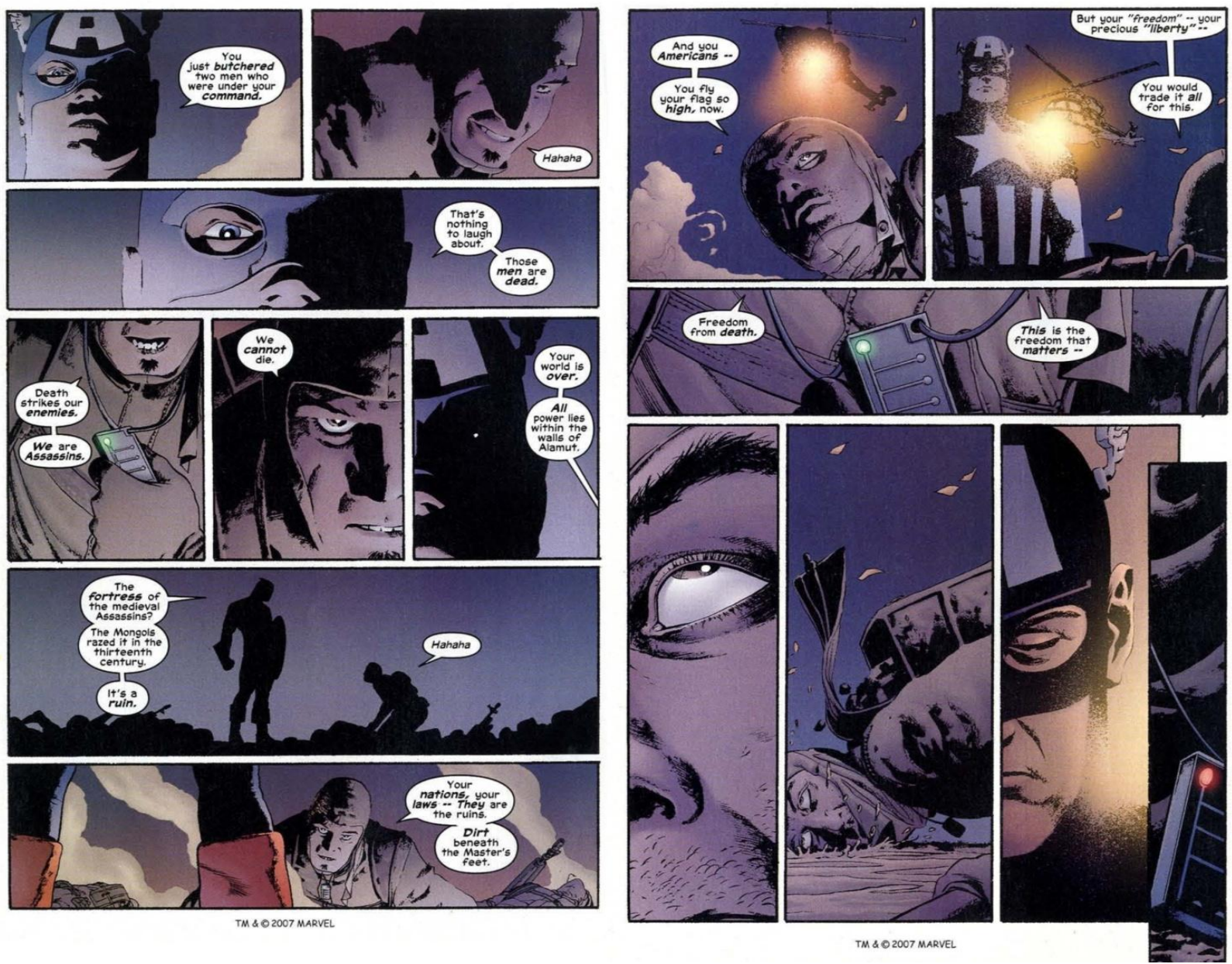

Figura 4. Capitão América dialogando com seu inimigo, um defende a vida outro a morte. (Captain America n5, p.20 e 22, out. 2002.)

O trecho acima fornece várias informações sobre os inimigos do Capitão América, primeiro fica novamente evidente que eles estão do lado da morte, matar e morrer é considerado por eles uma forma de "liberdade"; na trama da HQ os inimigos acreditam que os CATtags lhes dão imortalidade. A imagem do Capitão no penúltimo quadro da página transmite a impressão de que o herói lamenta pela morte do inimigo. Ademais, o trecho acima faz referência à seita dos Assassinos, que foi um grupo de dissidentes do Islã do ramo xiita ${ }^{136}$ surgido no Irã por volta de 1090, eles se utilizavam de adagas para praticar atos que podem

your "freedom"... your precious "liberty"... You would trade it all for this. Freedom from death... This is the freedom that matters..." (tradução nossa) Captain America n5, p.20 e 22, out. 2002.

${ }^{136}$ Xiitas e Sunitas constituem as duas principais ramificações de religião muçulmana. "A palavra "sunita" em si vem do termo "Sunnah", [...] como sendo os ensinamentos do Profeta Muhammad, porque estão estritos em obedecer a esses ensinamentos sem quaisquer introduções, interpolações ou omissões. A palavra xiita (Shi'a em árabe) significa um "partido", "seita", "apoiadores" ou um "grupo de indivíduos com o mesmo pensamento" [...]termo xiita foi primeiro usado entre os muçulmanos em relação à questão política sobre as quais os muçulmanos divergiram, 37 anos depois da morte do Profeta. Embora os xiitas aleguem que sua origem reside naquele cenário, o termo xiita para denotar essa seita específica ocorreu muito depois na história." Este trecho foi extraído do site "The Religion of Islam", disponível em: <http:/www.islamreligion.com/pt/articles/490/> Acesso em: 11/03/2014. 
ser chamados de terrorismo. Seus ataques eram direcionados contra autoridades muçulmanas sunitas e cruzados. A seita dos Assassinos adquiriu um relativo poder e se espalhou pelas montanhas da Síria e do Líbano, Alamut era uma das principais fortalezas desse grupo e foi destruída pelo imperador mongol Hulagu Khan, por volta do ano de 1256.

É difícil dizer por que os autores optaram por evocar a memória desses antigos terroristas islâmicos. Um indício do porquê dessa escolha está na entrevista que John Ney Rieber concedeu ao The Comic Journal. Nela, o escritor - que havia começado a escrever as HQs, aproximadamente em novembro de 2001, e como elas só seriam publicadas em junho de 2002 - achava que "quando a primeira edição sair, o Talibã, como nós o conhecemos, já não mais existirá." 137 (RIEBER, 2002, p.88, tradução nossa). Partindo desse comentário do escritor, pode-se deduzir que a escolha dos Assassinos como vilões da HQ tinha como objetivo evitar uma desatualização do conteúdo da narrativa. Rieber pretendia fazer com o Capitão América lutasse contra inimigos reais, mas como ele acreditava que estes inimigos não mais seriam considerados ameaças, optou por usar o que pode ser considerado como uma versão antiga de extremistas islâmicos e os reelaborou para se tornarem atuais e realistas dentro do contexto fictício das HQs.

Essa escolha também permite estabelecer algumas comparações entre a forma de ação da versão dos Assassinos da HQ, o grupo dos Assassinos medievais, e as ações de grupos terroristas islâmicos como a Al-Qaeda. Aparentemente, essa comparação foi inspirada no livro "Os Assassinos" do historiador Bernard Lewis, que no prefácio da edição de 2001 discute algumas das semelhanças entre esses terroristas medievais e o terroristas atuais, por exemplo:

a conexão sírio-iraniana, o uso calculado do terror, a total dedicação do agente assassino ao ponto de se imolar a serviço de sua causa e na expectativa da recompensa celestial. Alguns ainda têm visto mais similaridades no fato de ambos orientarem seu ataque contra um inimigo externo, os cruzados em um caso, os israelenses no outro ${ }^{138}$. (2003, p.07-08)

\footnotetext{
${ }^{137} \mathrm{O}$ texto original completo é o seguinte "And then, just the logistic of it, you're writing a story and it's not going to come out for five months. My personal feeling is, by time the first issue comes out the Taliban as we know it will no longer exist. And I kind of figure that from the beginning, these people have no idea, they really don't. They may think that they've stirred a hornet's nest, but it's tigers they've got." RIEBER, John Ney. In: The Comics Journal, 241, fevereiro de 2002.

${ }^{138}$ Lewis escreveu esse prefácio antes dos atentados de 11 de setembro (em abril de 2001) e faz referência aos atos terroristas praticados por extremistas islâmicos contra israelenses. Além disso, as comparações feitas por ele são questionáveis, pois elas podem induzir a uma interpretação de que os povos islâmicos são desde muito tempo ligados a ações violentas e com o terrorismo.
} 
Lewis acredita que estas comparações podem ser feitas, porém, para ele, a maior semelhança está no "equívoco" e não na realidade dos ataques. A crença de que os Assassinos atacavam os cruzados é um dos equívocos que pontua:

Na longa lista de suas vítimas, houve muito poucos cruzados, e mesmos estes, foram fruto de algum erro interno muçulmano. A maioria esmagadora de suas vitimas era de muçulmanos e seus ataques foram dirigidos, não contra o intruso, basicamente considerado sem importância, mas contra as elites dominantes e as ideias predominantes no mundo islâmico de seu tempo. (p.08)

Outra distinção que ele faz é com relação às vítimas dos Assassinos e dos terroristas atuais, os primeiros tinham alvos políticos específicos, "Eles só atacavam os grandes e poderosos, não pessoas comuns que se dedicavam a suas atividades cotidianas.” (Ibidem). Lewis afirma que a autoimolação era uma das características das ações dos Assassinos, eles, ao terem

[...] abatido a vítima designada, não faziam qualquer tentativa de fugir, nem havia qualquer tentativa de resgatá-lo. Ao contrário, sobreviver a uma missão era considerado uma desgraça. Nesse aspecto, os Assassinos podem ser vistos como precursores dos homens-bomba suicidas de hoje. (p.09)

Com relação a esse aspecto de autoimolação da ação dos terroristas, não há muitas referências ao tema nas HQs, exceto a já mencionada ação do jovem suicida e os quadros da primeira edição que descrevem como ocorreram os atentados. De fato, o que as HQs deixam em evidência não é o caráter suicida das ações dos terroristas, mas sim a determinação em sacrificar suas vidas pelo que acreditam, porém, na fala do terrorista da HQ citada acima, fica explícito que, além da disposição a se sacrificar, ele acredita que de fato não irá morrer, e será ressuscitado pelo objeto que carrega consigo. Isto pode ser interpretado como uma referência à crença que os terroristas da Al-Qaeda têm na possibilidade de ressurreição. Mohamed Atta, egípcio que teria sido o líder dos sequestradores ${ }^{139}$, nos fornece uma evidência disto em seu testamento divulgado pelo FBI, em 20 de setembro de 2001, quando afirma: "Eu acredito que o profeta Maomé é o mensageiro de Deus e não tenho dúvidas de que chegará o tempo em que Deus ressuscitará aqueles que estão em seus túmulos. "140

Nas HQs, esse teor religioso que vemos no testamento de Atta e em muitos discursos de terroristas islâmicos, quase não é mencionado. Os terroristas das HQs pouco expressam sua

\footnotetext{
${ }^{139}$ Para uma lista completa com o nome e características dos envolvidos nos atentados, recomendo visitar o site:<http://dialogospoliticos.wordpress.com/2011/09/01/conheca-os-19-terrorista-que-atuaram-no-ataque-de-11de-setembro/>

${ }^{140} \mathrm{O}$ testamento de Mohamed Atta foi escrito em 1996 e foi encontrado na mala que ele teria deixado em um aeroporto, o texto foi escrito em árabe e traduzido para o inglês; o trecho citado acima é o seguinte: "I believe that prophet Mohamed is God's Messenger and time will come to no doubt about that and God will ressurrect people who are in their graves." (tradução nossa). O texto especifica o que deverá ser feito com o corpo de Atta após sua morte e como seus bens deverão ser divididos. Testamento completo em inglês disponível em: <http://www.abc.net.au/4corners/atta/resources/documents/will1.htm> Acesso em: 27/01/2014.
} 
visão religiosa, o diálogo entre o Capitão e o terrorista mencionado anteriormente é o único no qual percebemos que esses homens possuem uma orientação e uma justificativa religiosa. O foco das HQs está no discurso político dos terroristas, mas isto não significa que a visão religiosa deles não seja questionada. Passaremos agora a analisar como essas HQs abordaram (e que opinião elas difundiram sobre) a religião muçulmana.

\subsection{Preconceitos com relação à religião muçulmana}

Na primeira edição da série, o Capitão América faz alguns questionamentos com relação a como a religião é usada pelos terroristas islâmicos; enquanto procura obstinadamente por sobreviventes em meio aos destroços do WTC (Figura 5.).

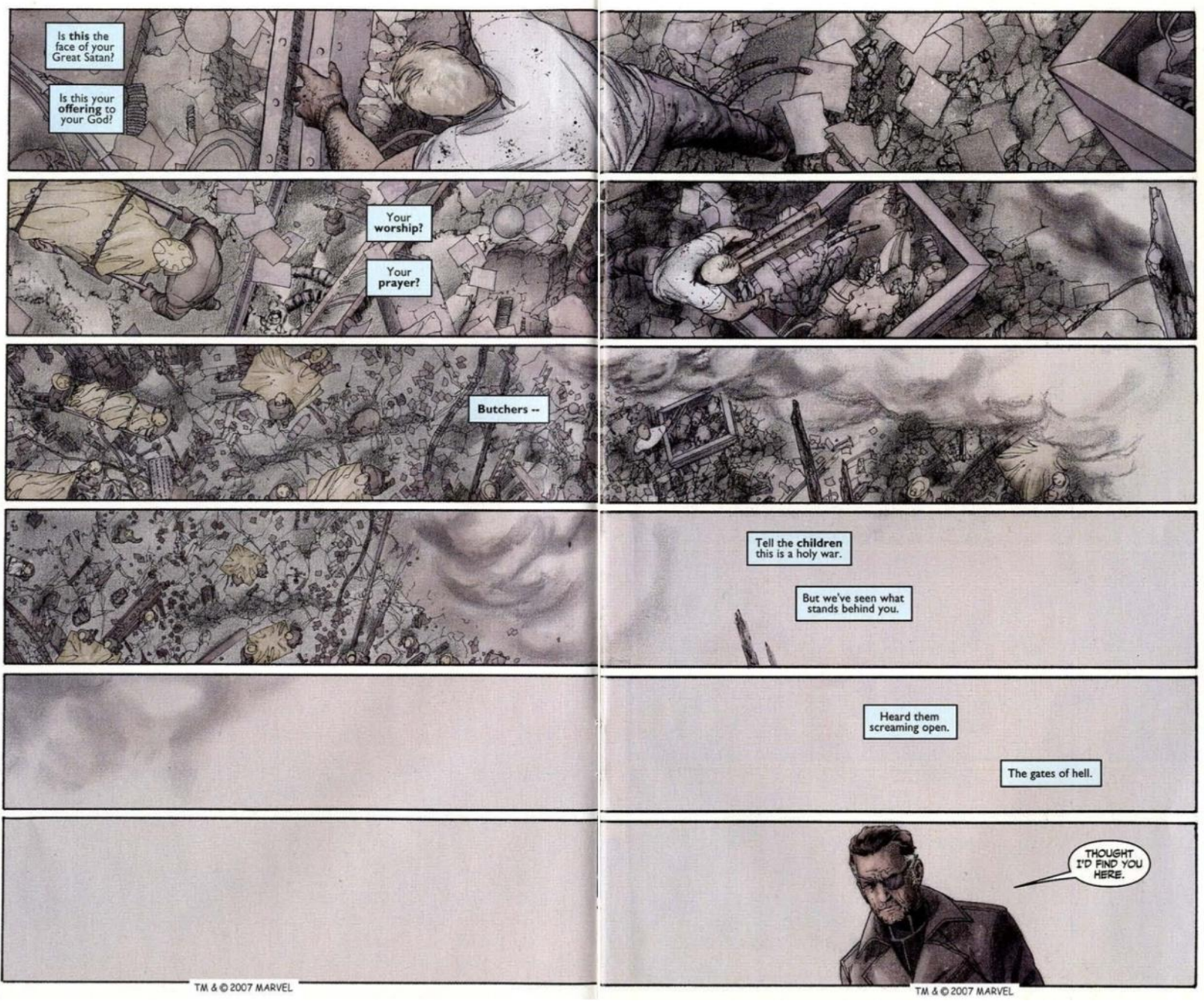

Figura 5. Essas duas páginas permitem ao leitor contemplar o amplidão dos estragos causados e quem são as pessoas que estão do lado do bem. (Captain America n ${ }^{\circ} 1$, p.16 e 17, jun. 2002.) Obs. O homem que aparece no último quadro é Nick Fury. 
Steve Rogers pensa nas seguintes questões e acusações:

Esta é a face de seu Grande Satã? Esta é sua oferenda ao seu deus? Sua veneração? Sua prece? Assassinos (ou açougueiros ao pé da letra)... Dizer às crianças que isto é uma Guerra Santa. Mas, nós vimos o que está por trás de vocês. Ouvimos quando se abriram. Os portões do inferno. ${ }^{141}$

No trecho acima se evidencia uma grande crítica ao discurso religioso empregado pelos terroristas. A primeira questão contesta o rótulo de "Grande Satã" atribuído aos Estados Unidos pelos terroristas - de acordo com o historiador iraniano, Abbas Amarat, esse rótulo foi cunhado pelo Aiatolá Khomeini ${ }^{142}$ (1900-1989):

Depois que seus seguidores sitiaram a embaixada americana e fizeram seus funcionários reféns, em 1980-81, Khomeini rotulou os Estados Unidos de Grande Satã por seu apoio aos poderes "faraônicos" - uma referência ao xá e governantes conservadores dos demais países da região - e por reprimirem os "deserdados" da Terra. (2002, p.49)

Esse rótulo faz parte de uma visão político/religiosa que, para legitimar suas ações nacionalistas, elegeu e denominou seu principal inimigo como sendo o representante de todo o mal existente. Na parte mencionada da HQ há uma inversão dessa alegação, a veracidade desse rótulo é questionada pelo Capitão América. As imagens mostram ao leitor uma parte da destruição causada pelos ataques e a única conclusão que se pode ter é a de que quem fez aquilo é, de fato, o Grande Satã. Isso é reforçado pelas acusações do herói de que eles são assassinos, e que o que eles chamam de Guerra Santa não teria nada de "santa". Enquanto isso, nos quadrinhos são mostrados os voluntários trabalhando para resgatar algum sobrevivente, consequentemente, quem está do lado do mal não são os Estados Unidos.

As opiniões expostas pelo Capitão América apresentam um caráter maniqueísta, comparável ao que os extremistas islâmicos usam. Vale ressaltar que essa visão mais extrema da religião muçulmana é a única com a qual os leitores têm contato. Na verdade, nas HQs não há nenhuma menção direta ao Islã. Contudo, também não existe em nenhum momento uma apresentação de outra versão do Islã, o leitor acaba sendo induzido a interpretar a religião muçulmana como uma crença de mentiras, que profere falsas acusações e é capaz de

\footnotetext{
141 "Is this the face of your Great Satan? Is this your offering to your God? Your worship? Your prayer? Butchers... Tell the children this is a holy war. But we've seen what stand behind you. Heard them screaming open. The gates of hell”. (tradução nossa e grifo no original) Captain America nº 1 p.16 e 17, jun. 2002.

${ }^{142}$ Khomeini foi um importante líder religioso que, em 1979, foi responsável pela revolução iraniana e, posteriormente, a fundação da república islâmica. Com a revolução, Khomeini "evocou, em todo o mundo muçulmano, o há muito acalentado desejo de criar um regime genuinamente islâmico. Conquanto, fosse pregado por um clero Shi'a radical que cometeu enormes atrocidades contra seu próprio povo; o modelo iraniano de islã revolucionário foi visto como indicador do caminho para um islã 'autêntico' e universalista. Valendo-se de fitas cassete e passeatas, os revolucionários iranianos conseguiram derrubar o Xá e o poderoso regime Pahlevi, a despeito de seu vasto arsenal militar, programa de secularização e sustentação ocidental. A retórica antiimperialista da revolução foi uma fonte de poder ainda maior.” (AMARAT, 2002, p.49).
} 
assassinar milhares de seres humanos inocentes como uma forma de oferenda a Deus. As já mencionadas páginas iniciais da HQ que mostram os terroristas numa caverna comemorando e agradecendo a Deus pelo sucesso de seu ataque também transmitem essa visão de que a fé muçulmana é voltada para o mal - e a caverna tem um quê de atraso. Essa forma como a religião muçulmana é representada nas HQs contém características que podem ser definidas como uma manifestação de "islamofobia". De acordo com Lindsey Hanlon,

O termo islamofobia é uma abreviação verbal para uma ampla gama de crenças, atos de fala, políticas e ações. Embora não seja especificamente sinônimo de racismo, xenofobia ou intolerância religiosa, ele é composto de elementos de todos esses conceitos. Como definido por Peter Gottschalk e Gabriel Creeberg é uma " 'ansiedade do Islã'... uma ansiedade social para com o Islã e culturas muçulmanas que em grande parte não são examinados, porém, profundamente arraigados em norte-americanos". Ambas as formas conscientes e inconscientes da islamofobia tem um efeito considerável sobre a vida dos indivíduos muçulmanos a nível político, cultural e pessoal. (2012, p.02, tradução nossa) ${ }^{143}$

Divulgar esse tipo de sentimento islamofóbico aparentemente não é a intenção dos autores. Todavia, ao não fornecerem aos leitores outra interpretação do que é a religião mulçumana, inconscientemente, eles deram margem para divulgar esse tipo de sentimento. Podemos afirmar que isso não é intencional, pois os autores se deram ao trabalho de incluir na narrativa o personagem árabe-americano Samir que é identificado como um norte-americano que tem uma origem multirracial, no entanto, sua religião não é mencionada e aparentemente não importa. A única coisa que fica expressa de forma clara é que Samir não tem nada a ver com os atentados de 11 de setembro, ele não é um terrorista - apesar de ser de origem árabe -, na verdade, ele é um cidadão americano que também ficou estarrecido com o ocorrido e tenta seguir sua vida de forma normal.

Como já dissemos no capítulo anterior, o papel de Samir na narrativa é fazer um apelo para que os americanos não se deixem dominar pelo ódio e que não saiam pelas ruas agredindo qualquer um que acreditem ser um inimigo. A tolerância e a união entre os diferentes cidadãos é a principal mensagem divulgada. Todavia, o mesmo não ocorre com as religiões. Isto fica evidente ao compararmos como o Cristianismo é representado nas HQs, quando os terroristas invadem a igreja em Centerville numa manhã de Páscoa (Figura 6.), o

\footnotetext{
143 "The term "Islamophobia" is verbal shorthand for a wide range of beliefs, speech acts, policies, and actions. While it is not specifically synonymous with racism, xenophobia, or religious intolerance, it is composed of elements from all of these concepts. As defined by Peter Gottschalk and Gabriel Greenberg, it is an " anxiety of Islam'... a social anxiety towards Islam and Muslim cultures that is largely unexamined by, yet deeply ingrained into, Americans". Both conscious and unconscious forms of Islamophobia have a considerable effect on the lives of Muslim individuals at the political, cultural, and personal level." (HANLON, 2012, p.02). O texto completo esta disponível em:< http://fisherpub.sjfc.edu/cgi/viewcontent.cgi?article=1038\&context=nepca $>$ Acesso em: 03/03/2014.
} 
primeiro quadro da página mostra a igreja e um painel onde se lê: "CERIMÔNIA DE PÁSCOA TODOS SÃO BEM-VINDOS" [EASTER SERVICE ALL ARE WELCOME]. No quadro seguinte, o pastor diz:

É bom ver tantos visitantes aqui nesta manhã. Vizinhos... Vocês sabem que nós sempre ficamos felizes em vê-los. Desconhecidos... Esperamos que vocês nos deem a chance de conhecê-los melhor, após a cerimônia. Oremos. ${ }^{144}$ (nesse momento a igreja é invadida)
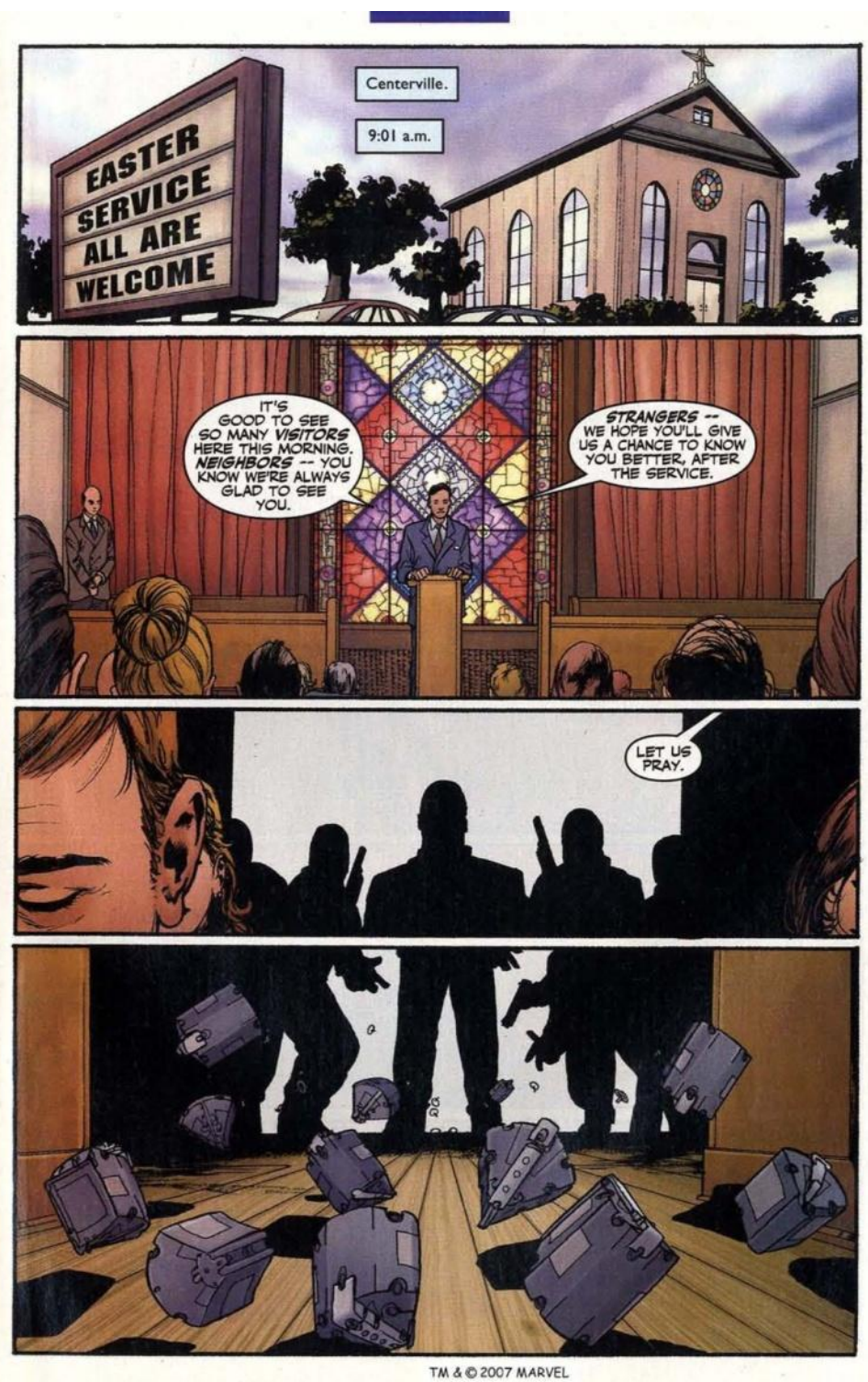

Figura 6. Todos são bem-vindos na igreja, e os cristãos estão dispostos a conhecer melhor o outro. (Captain America n 20, p.05, jul. 2002.)

Analisando essa parte da HQ, constata-se que os autores tiveram a preocupação de mostrar, de forma muito idealizada, alguns aspectos de como ocorre uma celebração religiosa

144 "It's good to see so many visitors here this morning. Neighbors...you know we're always glad to see you. Strangers... we hope you'll give us change to know you better, after the service. Let us pray" (tradução nossa e grifo no original) Captain America no 2, p.05, jul. 2002. 
cristã. A igreja é caracterizada como um local aberto onde "todos são bem-vindos", a comunidade cristã representada tem interesse em "conhecer melhor" aqueles que ali estão pela primeira vez. A religião cristã é apresentada de forma positiva se comparada com a forma como o Islã foi indiretamente mostrado nas HQs. Quando os terroristas invadem a igreja e fazem todos de refém, transmite-se a ideia que eles não têm a mesma tolerância que os cristãos manifestam, pois não demonstram respeito, nem pelo significado religioso da Páscoa, nem pelas pessoas que estavam na igreja manifestando sua fé.

De acordo com Jason Dittmer (2005), essa parte da HQ pode ser interpretada como uma referência à tese de "choque de civilizações" proposta pelo economista Samuel Huntington (1927-2008). Em linhas gerais, a tese de "choque de civilizações" apresenta a ideia de que os conflitos mundiais no século XXI serão marcados pelas disputas entre diferentes culturas e religiões. Com relação ao Islã e o Cristianismo, Huntington afirma que

Alguns ocidentais, dentre eles o presidente Bill Clinton, têm afirmado que o Ocidente não tem problemas com o Islã, mas apenas com os violentos extremistas fundamentalistas islâmicos. Mil e quatrocentos anos de História provam o contrário. As relações entre o Islamismo e o Cristianismo, tanto Ortodoxo como Ocidental, foram frequentemente tempestuosas. Cada um o Outro do outro. $O$ conflito do século XX entre a democracia liberal e o marxismo-leninismo é apenas um fenômeno fugaz e superficial, se comparado com a relação continuada e profundamente conflitiva entre o Islamismo e o Cristianismo. Em alguns períodos, prevaleceu uma coexistência pacífica, mas na maioria das vezes essa relação foi de la guerra fria e de diversos graus de guerra quente. (1997, p.262, grifo no original)

No texto de Huntington - além de apresentar uma crítica ao antecessor de Bush -, são feitas afirmações de caráter generalizador e, até certo ponto, pessimista, que geraram diversas controvérsias e críticas por declarar que, devido ao histórico de conflitos entre cristãos e muçulmanos, a convivência pacífica entre essas duas religiões é impossível. Além disso, Huntington diz que: "Quaisquer que sejam suas opiniões religiosas ou políticas, os muçulmanos estão de acordo em que existem diferenças entre a sua cultura e cultura ocidental." (Ibidem, p. 268).

Huntington também explana como os muçulmanos, a partir dos anos 80 e 90 do século $\mathrm{XX}$, passaram a manifestar um crescente sentimento antiocidental, no qual as diferenças entre as duas civilizações foram acentuadas. Os muçulmanos defendem "a superioridade da sua cultura e a necessidade de manter a integridade dessa cultura contra o ataque ocidental. [...] Eles veem a cultura ocidental como materialista e corrupta, decadente e imoral." (Ibidem, p.267). Essa última afirmação de Huntington é claramente expressa pelos inimigos do Capitão América, na segunda edição da série, quando um dos terroristas, com uma arma, obriga a 
repórter Jessica Seldon a ler um comunicado deles e, no último quadro, chama a moça de "prostituta[...] de boca pintada"145. Esse pequeno quadro contribui para reforçar como a visão de mundo dos terroristas e dos americanos é diferente, inclusive, com relação às mulheres, o simples fato de a repórter estar usando batom a transforma em uma prostituta aos olhos dos terroristas - o que, todavia, poderia também ser remetido para diferenças culturais não demonizadoras.

Tanto o trabalho de Huntington quanto as HQs apresentam um determinado grau do que Edward Said (1935-2003) chama de “orientalismo”. Said afirma que

[...] o que é definido atualmente como "islã", tanto na Europa como nos Estados Unidos, pertence ao discurso do orientalismo, uma construção fabricada para fomentar hostilidade e antipatia contra uma parte do mundo que, por acaso, tem importância estratégica devido ao seu petróleo, sua proximidade ameaçadora do mundo cristão e sua formidável história de rivalidade com o Ocidente. (2003, p.333)

No trecho citado, Edward Said procura criticar o trabalho de Samuel Huntington (e também do historiador Bernard Lewis ${ }^{146}$ ). Para Said, quando Huntington proclama que existe um "choque de civilizações", ele estaria contribuindo para a construção de uma imagem falsa do Islã e esta visão preconceituosa serviria apenas para estabelecer um "novo" inimigo contra o qual os Estados Unidos (e o Ocidente) deveriam lutar. Said entende que Huntington, e outros autores que ele menciona, estariam reforçando a criação de maiores conflitos entre o chamado Ocidente e o Oriente, pois estes teriam culturas (ou civilizações) naturalmente incompatíveis e que não têm como se conciliarem. Said acredita que a melhor maneira de tratar a questão seria por meio de uma maior interação entre as diferentes culturas que existem no mundo e por uma busca por elementos que as tornem semelhantes, tendo em vista a construção de uma interação harmônica entre todos.

Com relação à tese de Huntington, Jason Dittmer segue a mesma linha de pensamento de Said e firma que

Nesta narrativa geopolítica, cultura e religião servem como o cisma fundamental na política mundial, e a situação geopolítica atual derivada da modernidade secular colhendo a tempestade do renascimento religioso. Assim, enquanto as ações americanas no passado podem ter causado atrito, o conflito em si é um resultado inevitável de culturas incompatíveis. O Islã, em particular, é apresentado como um exemplo de uma civilização

\footnotetext{
145 Texto completo do quadro é o seguinte: "Up, whore. With your painted mouth. Read." (tradução nossa) Captain America n², p.13, jul. 2002.

${ }^{146}$ Para maiores informações sobre as críticas que Edward Said faz ao trabalho de Lewis, recomendamos a leitura de "Orientalismo" (publicada originalmente em 1978) que é uma das obras mais conhecidas do autor, na qual pode-se ter contato com diversas críticas que Said faz a Lewis e outros autores contribuíram e ainda contribuem para a construção e difusão de uma interpretação equivocada sobre o que é o Oriente.
} 
intrinsecamente ligada à violência religiosa. (DITTMER, 2005, p.639, tradução nossa) $)^{147}$

Além disso, Dittmer também afirma que após os atentados de 11 de setembro, a ideia de que existe um "choque de civilizações" tornou-se dominante e até mesmo comprovada. De acordo com Derek Gregory ${ }^{148}$ (2004, p.58 apud DITTMER, 2005, p.639), muitos têm usado essa ideia para legitimar políticas de repressão e para orientar ações internacionais que objetivam desestabilizar a suposta ameaça islâmica. Outros ainda se utilizam dos argumentos de Huntington para negar que Islã seja, de fato, uma civilização.

No período que se seguiu aos atentados, os meios de comunicação dos Estados Unidos difundiram diferentes níveis de mensagens preconceituosas, orientalistas ou islamofóbicas ${ }^{149}$. Para Lindsey Hanlon, isso tudo

Reflete uma paranoia cultural, sugerindo que o Outro Islâmico "aceitável" apenas aparenta ser similar aos americanos, mas, na verdade, eles só os estão iludindo através desta suposta similaridade, e estão simplesmente ganhando tempo antes de atacar. Sob esta atitude, qualquer e todos os Outros Islâmicos são suspeitos, inimigos em potencial à espreita. (2012, p.09, tradução nossa) ${ }^{150}$

Esse imaginário de que existe um inimigo à espreita, somado à dor da perda de entes queridos e ao medo de que novos ataques pudessem ocorrer, contribuíram para a criação de todo um quadro de violência e desconfiança muito próximo do retratado pelas HQs do Capitão América, no qual, muitos se sentiram no direito de agir, fazer justiça com as próprias mãos e eliminar de seu país todo estrangeiro suspeito.

De acordo com o jornalista Farzanah Asmal (2008, p. 30 e 31) ${ }^{151}$, a forma como se deu a cobertura da mídia sobre os atentados de 11 de setembro foi permeada por uma islamofobia

\footnotetext{
147 "In this geopolitical narrative, culture and religion serve as the fundamental schism in world poli- tics, and the current geopolitical situation derives from secular modernity reaping the whirlwind of religious re- vival. Thus, while American actions in the past may have caused friction, the conflict itself is an inevitable result of incompatible cultures. Islam, in particular, is given as an example of a civilization innately tied to religious violence.” (DITTMER, 2005, p.639).

148 GREGORY, Derek. The colonial present: Afghanistan, Palestine, Iraq. Massachusetts: BlackWell Prublishing, 2004.

${ }^{149}$ Com relação a difusão de uma imagem preconceituosa de árabes e muçulmanos nos meios de comunicação norte-americanos, recomendamos o livro e o documentário "Reel Bad Arabs: how Hollywood vilifies a people" (2001 e 2006) de Jack Shaheen. O autor analisa diversos filmes produzidos antes e depois do 11 de setembro e mostra que tipo de imagem eles passam sobre os povos de origem árabe/muçulmano. O documentário pode ser facilmente encontrado gratuitamente na internet; no YouTube é possível assistir uma versão legendada em português: http://www.youtube.com/watch?v=f3o4Rtp2jTQ

150 "It reflects a cultural paranoia, suggesting that "acceptable" Islamic Others only appear to be similar to Americans, but are in fact deceiving through their supposed similarity, and are simply biding their time before they strike. Under this attitude, any and all Islamic Others are suspect, potential enemies lying in wait." (HANLON, 2012, p.09).

${ }^{151} \mathrm{O}$ foco da pesquisa de Farzanah Asmal é analisar como essas mensagens islamofóbicas foram transmitidas pelos meios de comunicação nos Estados Unidos e na Europa, e analisa o caso de uma caricatura polêmica
} 
recorrente: "A mídia toda se apressou em apontar os muçulmanos como culpados pelas mortes de milhares de americanos em 11/9, mas falhou em mencionar o papel da América como uma superpotência e seu envolvimento em ataques a outros países." (ASMAL, 2008, p.32 tradução nossa) ${ }^{152}$. Com relação a esse último ponto, as HQs do Capitão América não "falharam", pois como já mencionamos em diversas partes deste trabalho, mostrar as consequências das ações dos Estados Unidos foi uma das propostas dos autores.

Essas HQs aparentemente são uma exceção; os grandes veículos de comunicação, de modo geral, reproduziram informações que seguiam as declarações feitas pelo presidente George W. Bush, que estabeleceu uma visão maniqueísta na qual a Guerra ao Terror seria uma luta entre o "Bem" e o "Mal", contribuindo para o estabelecimento de uma "[...] 'cultura de medo' povoada por um vasto conjunto de ameaças." (ASMAL, 2008, p.33 tradução nossa) 153. Mesmo refletindo preconceito com relação à religião muçulmana, os autores das HQs procuraram não contribuir para incentivar essa "cultura do medo". Ao invés disso, transmitem mensagens de esperança, tolerância e união, como evidencia a já mencionada participação de Samir na HQ, que perdoa seu agressor (Figura 7.) e pede para que o Capitão o deixe ir. Samir também demonstra que sente muito pela perda de seu conterrâneo nova-iorquino e, no penúltimo quadro, eles apertam as mãos, em um claro sinal de reconciliação e respeito.

publicada em 2005 no jornal dinamarquês "Jyllands-Posten", que apresentava o profeta Maomé com uma bomba em seu turbante. Essa caricatura e outros desenhos podem ser vistas no trabalho de Asmal disponível em: <http://scholar.sun.ac.za/handle/10019.1/3326> Acesso em: 10/04/ 2014.

152 "The media were all quick to assign to blame Muslims being responsible for the death of thousands of Americans who died on 9/11, but failed to mention America's role as a superpower and its involvement in and attacks on other countries (Karim, 2003:106)." (ASMAL, 2008, p.32). Nesse trecho, o autor faz uma citação indireta de um texto de KARIM, Karim H. "Making sense of the "Islamic Peril": journalism as cultural practice". In: ZELIZER, Barbie; ALLAN, Stuart. (org.) Journalism After September 11. London: Routledge, 2003.

153 “[...] a "culture of fear" populated by a vast array of threats." (ASMAL, 2008, p.33). 

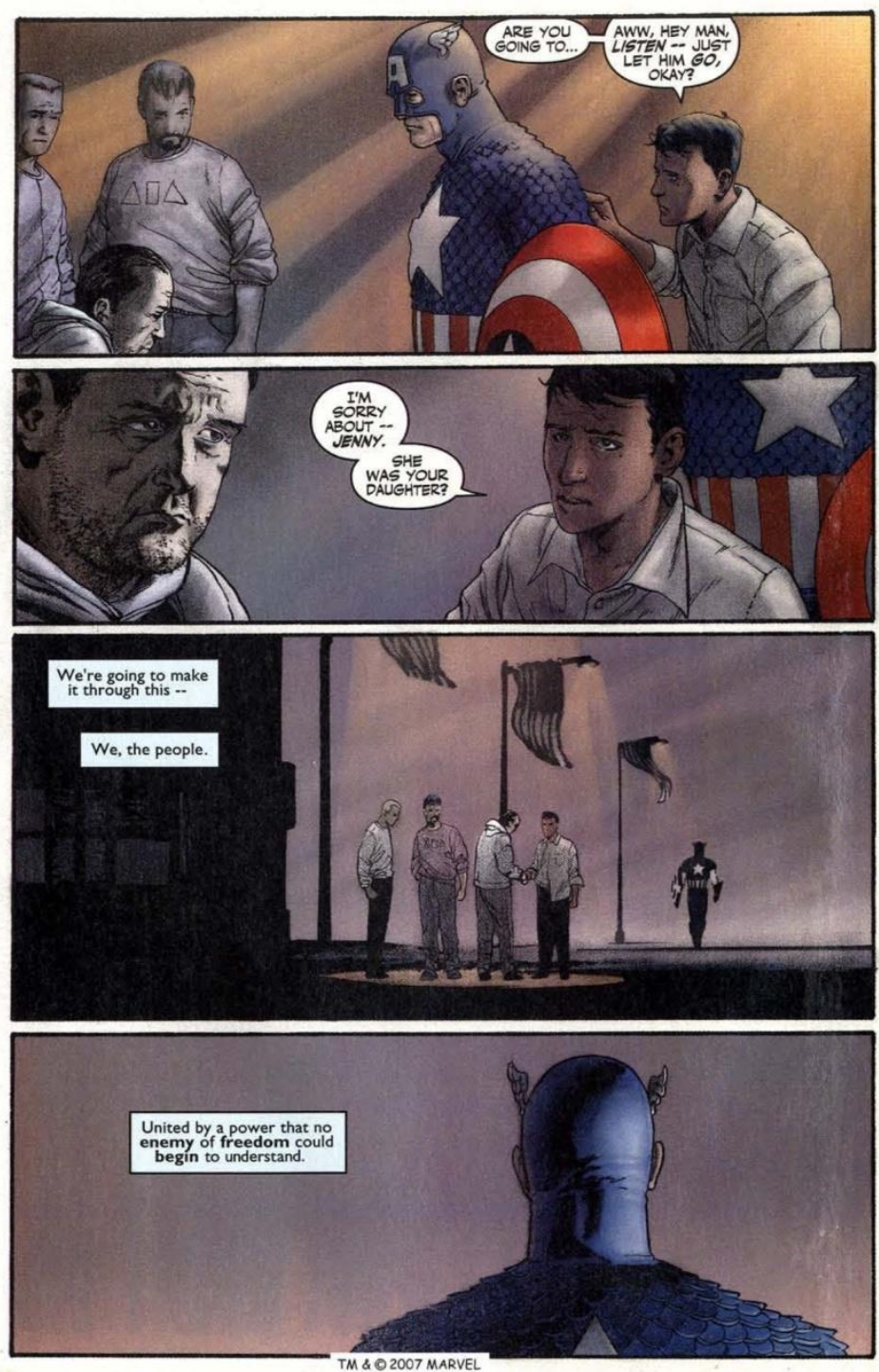

Figura 7. Mesmo expondo alguns preconceitos quanto ao Islã, a principal mensagem da HQ é a tolerância e a união. (Captain America n ${ }^{\circ} 1$, p.32, jun. 2002.)

Essa contradição de mensagens que as HQs transmitem pode ser atribuída à confusão e ao excesso de informações que foram divulgadas logo após os atentados, que deram vazão a uma série de sentimentos controversos. De acordo com Julian Darius, o conteúdo dessas aventuras do Capitão América apresenta "três tendências: patriotismo, sentimentos antiárabes, e antiamericanos." (2003, tradução nossa) ${ }^{154}$. Essas tendências presentes nas HQs contribuem para que seu conteúdo seja contraditório.

$\mathrm{Na}$ perspectiva de Darius, o patriotismo desses quadrinhos é evidente em vários momentos. Está presente nas capas do Capitão América que, por si só, já é um símbolo

154 “[...] three tendencies begin to dovetail: patriotism, anti-Arab sentiment, and anti-American sentiment. The patriotic element is visible from the start." (DARIUS, 2003). Texto disponível em: <http://sequart.org/magazine/1981/the-intellectual-rip-off-of-captain-americas-the-new-deal/ > Acesso em: 08/03/2014. 
patriótico, e na comparação entre os Estados Unidos e seus inimigos, ressaltando as virtudes do povo americano - como a força e cooperação para superar o trauma -, em contraste com o inimigo estrangeiro que personifica uma cultura hostil e associada ao mal. O patriotismo e os "sentimentos anti-árabes" podem ser entendidos como faces da mesma moeda, e a oposição entre os dois é usada para determinar a identidade do povo dos Estados Unidos. Quanto ao que Julian Darius chama de "antiamericanismo", ele estaria presente nas críticas que os autores fazem a determinadas ações dos Estados Unidos.

Esse antiamericanismo é proveniente, principalmente, das falas dos inimigos que o personagem enfrenta ao longo da HQ: todos os inimigos, de Al-Tariq ao Mestre dos terroristas, fazem críticas contundentes aos Estados Unidos. O Mestre dos terroristas é o que apresenta as críticas mais embasadas, pois faz referências às ações dos Estados Unidos em outros países e se apresenta como fruto da Guerra Fria e das intervenções indiretas realizadas nesse período. Além disso, o Mestre não é só um soldado inimigo agindo para vingar seu país de algum ataque americano, é uma vítima direta dessas ações dos EUA que conseguiu seguidores e recursos para realizar sua vingança.

Ao lutar contra o Mestre, o Capitão é forçado a encarar as consequências das ações de seu país; uma das vítimas conseguiu de algum jeito arquitetar um plano de vingança bem elaborado. E agora o herói deve derrotá-lo, deve superar seu desejo de se vingar pelo que os terroristas fizeram em Centerville. Esse combate não se resolve de uma forma fácil, há questões morais complexas que devem ser resolvidas. Do ponto de vista do Capitão América, por mais que alguém tenha sofrido, isto não lhe dá o direito de fazer justiça com as próprias mãos. Ele deve controlar seu ódio, agir de forma diferente da do Mestre, provar para os leitores que a afirmação feita pelo Mestre de que eles são “iguais"155 (Figura 8.) não tem cabimento.

\footnotetext{
${ }^{155} \mathrm{O}$ texto na integra é o seguinte: "This man is my equal. His death is mine." (tradução nossa) Captain America no6, p.24, dez. 2002.
} 

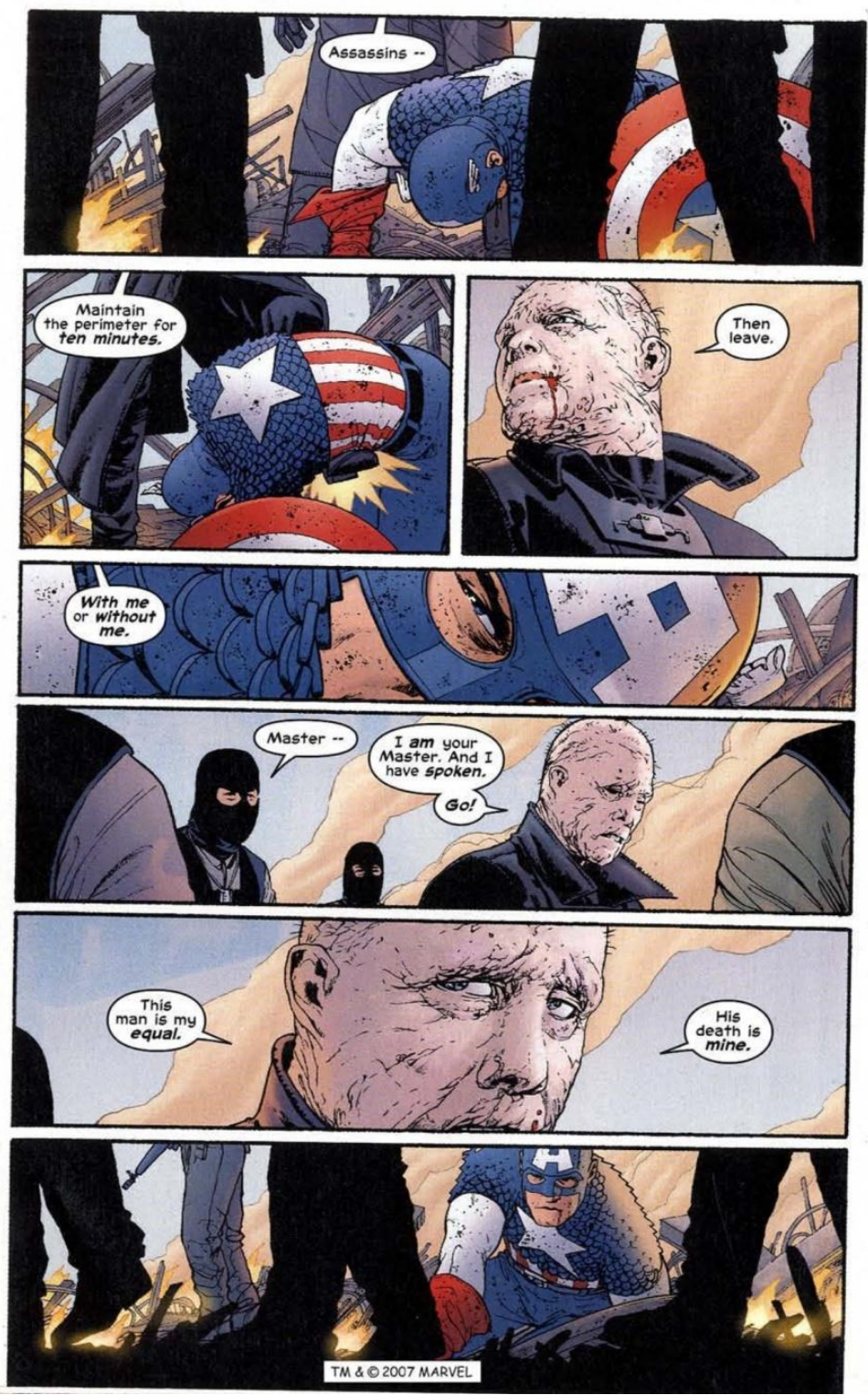

Figura 8. Capitão América x Mestre dos terroristas. Uma luta entre "iguais"? (Captain America $\mathrm{n}^{\mathrm{o}} 6$, p.24, dezembro de 2002.)

É possível identificar que o herói e o vilão têm algumas semelhanças como, por exemplo, ambos assumiram um papel de defensores de seus povos. Entretanto, o Mestre reivindicou para si o papel de defensor/vingador de todas as vítimas e possíveis vítimas inocentes dos atos imperialistas dos EUA. Assim, nesse momento, pode-se dizer que a oposição entre herói e vilão não fica bem clara, pois ambos possuem justificativas morais para suas ações. Mas, o Capitão América se diferencia do terrorista por ter respeito à vida de inocentes e por ter um ideal considerado mais justo pelo qual lutar. Todavia, tanto o "vilão" quanto o "herói", possuem ideais que motivam suas ações e o valor de cada um desses ideais depende do ponto de vista. 
Outra diferença entre o herói e seu antagonista está na capacidade de reconhecer erros e de assumir responsabilidades. Por ser uma vítima dos Estados Unidos, o Mestre dos terroristas pode ter justificativas plausíveis para tirar a vida de outras pessoas, porém isso não é apresentado como uma atitude correta. Mesmo reconhecendo que as acusações feitas com relação a seu país são verdadeiras, o Capitão acredita que elas fazem parte do passado dos Estados Unidos e que o país aprendeu com seus erros. Como vimos, o Capitão América também mudou, ele não age da mesma maneira que fazia no passado.

O herói acredita que seu país também mudou, pelo menos no mundo da ficção e na fala do Capitão, os Estados Unidos não são mais o mesmo país que cometeu inúmeros crimes de guerra em diferentes localidades do mundo. Não são mais o mesmo país que, de forma indireta, foi responsável pela tragédia pessoal do Mestre dos terroristas (e de outros) e motivou sua empreitada vingativa. E, de uma forma mais ampla, a HQ diz que os Estados Unidos aprenderam e que não irão mais agir do mesmo jeito, o 11 de setembro os fez refletir e perceber as consequências das políticas que eles vêm empreendendo desde o final da Segunda Guerra Mundial.

\subsection{Capitão América antipatriótico?}

Assumir que os Estados Unidos têm agido de forma, no mínimo inapropriada, ao longo de suas intervenções internacionais, pode ser considerado como uma manifestação de antiamericanismo do próprio Capitão América? Para Michael Medved ${ }^{156}$ a resposta para essa questão é sim, em um artigo publicado na National Review Online, em abril de 2003, ele acusou estas HQs do Capitão América de serem antiamericanas, pois mostram o

Capitão América, o super-herói patriótico cujas façanhas nos quadrinhos tenha inspirado a nação na Segunda Guerra Mundial, agora ele se sente incerto sobre a causa da nação; em suas últimas aventuras, o Sentinela da Liberdade parece desiludido, amargurado, e surpreendentemente simpático aos terroristas. ${ }^{157}$

\footnotetext{
${ }^{156}$ Medved é escritor, radialista, comentarista político e crítico de filmes. Tem vários livros publicados sobre temas relacionados à política dos EUA e é membro do partido Republicano.

157 "Captain America, the patriotic superhero whose comic-book exploits inspired the nation in World War II, now feels uncertain about the nation's cause; in his latest adventures, The Sentinel of Liberty seems disillusioned, embittered, and surprisingly sympathetic to terrorists." MEDVED, Michael. Captain America, traitor?: The comic book hero goes anti-American. In: National Review Online, em abril de 2003. (tradução nossa). Disponível em: <http://www.nationalreview.com/articles/206451/captain-america-traitor/michaelmedved> Acesso em: 09 de maio de 2014.
} 
Para Medved, as HQs estão passando uma imagem "errada" do que é América, principalmente, quando o herói assume a culpa dos EUA pelos crimes que eles teriam cometido. Além disso, Medved afirma que não esperava isso do Capitão América e que

Poderíamos esperar essa lógica de culpar a América de ativistas de Hollywood, apologistas acadêmicos, ou dos manifestantes que enchem regularmente as ruas de capitais européias (e muitas grandes cidades americanas). Quando esses sentimentos aparecem, no entanto, escondidos no interior de quadrinhos estrelados e com uma embalagem nostálgica dirigido às crianças, é preciso enfrentar esse mal-estar cultural profundo que aflige a nação às vésperas da guerra. ${ }^{158}$

Entretanto, ele não se dá ao trabalho de descrever como deveriam ser estas HQs, mas pode-se imaginar que ele preferisse um discurso mais unilateral e direcionado, como o do presidente Bush. Onde apenas o lado positivo da América e o esforço de guerra fossem ressaltados.

As críticas de Medved podem ser enquadradas no fenômeno que o advogado norteamericano Harold Hongiu Koh chamou de "correção patriótica", que seria uma espécie de autocensura executada por vários meios de comunicação com relação a determinadas opiniões ou atitudes

sob a justificativa de serem impatrióticos ou politicamente incorretos. Nos meses por vir, temos de nos manifestar sem rodeios, mesmo que a mensagem seja desagradável. Temos de dizer a verdade sobre as violações dos direitos humanos, sejam elas cometidas pelos terroristas ou por nossos parceiros de coalizão - israelenses ou palestinos, paquistaneses, talibãs ou membros da Aliança do Norte, ou até nossas próprias autoridades governamentais. (KOH, 2002, p.172.)

Assim, as acusações de antiamericanismo e antipatriotismo dirigidas às HQs do Capitão América refletem esse contexto de "correção patriótica", que foi marcado por uma crescente vigilância sobre os cidadãos e os meios de comunicação.

Para tanto, o governo norte-americano adotou novas medidas como um controle ainda mais rigoroso da entrada de estrangeiros nos EUA e também o monitoramento de diversos meios de comunicação, com o objetivo de prevenir novos atentados. Essas e outras práticas foram estabelecidas pelo "USA Patriot Act" (Uniting and Strengthening America by Providing Appropriate Tools Required to Intercept and Obstruct Terrorism Act of 2001), documento aprovado pelo Congresso em outubro de 2001. Em linhas gerais, esse documento permitiu a violação da privacidade e dos direitos civis dos cidadãos norte-americanos em nome do combate ao terrorismo. Isto fez com que muitos cidadãos americanos - sem falar nos

\footnotetext{
158 "We might expect such blame-America logic from Hollywood activists, academic apologists, or the angry protesters who regularly fill the streets of European capitals (and many major American cities). When such sentiments turn up, however, hidden within star-spangled, nostalgic packaging of comic books aimed at kids, we need to confront the deep cultural malaise afflicting the nation on the eve of war." (Ibidem).
} 
estrangeiros! - perdessem um de seus principais direitos que constituem o chamado American Way of Life: a liberdade.

Com relação aos danos causados à liberdade norte-americana, o historiador Eric Foner afirma que:

[...] todos os surtos patrióticos correm o risco de degenerar em um desenho coercivo das fronteiras entre "leais" norte-americanos e aqueles estigmatizados como estrangeiros e traidores. Como outras guerras, a "guerra ao terrorismo" levantou questões preocupantes em matéria de liberdades civis em tempo de guerra, os direitos dos não-cidadãos e fronteiras étnicas da liberdade americana. Não é difícil listar os numerosos e preocupantes violações às liberdades civis que se seguiram na esteira do 11 de setembro. Proteções legais, como habeas corpus, julgamento por júri imparcial, o direito de representação legal e igualdade perante a lei, independentemente da raça ou origem nacional foram reduzidos.(2004, tradução nossa) ${ }^{159}$

Além disso, Forner também afirma que na História dos Estados Unidos, a luta pelas liberades civis é "recente e ainda frágil", e cita diversos momentos historicos nos quais essas liberdades foram abreviadas; por exemplo, durante as duas Guerras Mundiais e o macartismo, na Guerra Fria. De acordo com Foner, “Os historiadores geralmente veem esses episódios do passado como vergonhosas anomalias. Mas, agora estamos passando por outra experiência desse tipo, e há uma notável ausência de protestos publicos." (Ibidem). ${ }^{160}$

Parte disso se deve à atuação da mídia que, de acordo com Michael Apple (2006) ,

[...] não só nos ajuda a construir a natureza dos problemas com que nos deparamos, mas também atua como um forte instrumento mobilizador. Para onde quer que nos voltemos, depois de 11 de setembro, há vozes na mídia que dizem a mesma coisa. As vozes dissidentes não estão totalmente em silêncio, mas o choque as afetou também, e suas mensagens foram emudecidas. (p.227)

Apple também fornece alguns exemplos de como essa onda de patriotismo afetou algumas instituições de ensino nos Estados Unidos, promovendo mudanças e cerceamento de diversas formas de expressão, vigiando o conteúdo que os professores ensinavam e o tipo de debates que esses conduziam. Tais medidas contradizem não apenas os ideais e as leis, mas

\footnotetext{
159 " [...] all patriotic upsurges run the risk of degenerating into a coercive drawing of boundaries between "loyal" Americans and those stigmatized as aliens and traitors. Like other wars, the "war on terrorism" has raised troubling questions concerning civil liberties in wartime, the rights of noncitizens, and the ethnic boundaries of American freedom. It is not difficult to list the numerous and disturbing infringements on civil liberties that followed in the wake of September 11. Legal protections such as habeas corpus, trial by impartial jury, the right to legal representation, and equality before the law regardless of race or national origin were curtailed." Trecho do texto "Rethinking American History in a Post-9/11 World" de 6 de setembro de 2004. Disponível em: < http://www.ericfoner.com/articles/090604hnn.html> Acesso em: 09/03/2014.

160 "Historians generally view these past episodes as shameful anomalies. But we are now living through another such experience, and there is a remarkable absence of public outcry." (Ibidem).
} 
também constituem um retrocesso na luta por direitos civis nos Estados Unidos. Apple também cita como o conceito de liberdade foi usado para justificar diversas atitudes:

Para alguns, era o perigo do terrorismo internacional destruir nosso modo de vida, que é livre. Nada deve interromper a defesa da liberdade norteamericana. Assim, as escolas deveraim estar na primeira linha de defesa. Para outros, tal liberdade não teria essencialmente nenhum significado se os cidadãos não pudessem agir de acordo com ela, especialmente em tempos de crise. Silenciar as vozes dissidentes e impor formas compulsórias de patriotismo eram atos antitéticos à liberdade.(2006, p.233)

Quanto a isto, podemos considerar as HQs do Capitão América um exemplo de meio de comunicação de massa que se propôs a discutir, de forma mais aprofundada, as questões que estavam presentes na sociedade americana após os atentados. Elas questionam a(s) guerra(s), o discurso governamental de inocência dos Estados Unidos.

A forma com que os autores deram voz aos terroristas não é uma demonstração de "simpatia pelo terrorismo", eles deixam claro que as ações daqueles homens não devem ser toleradas. Entretanto, essa mensagem das histórias em quadrinhos acabou não sendo ouvida, pois, segundo Nano Souza ${ }^{161}$ (2003), o conteúdo dessa série gerou alguns problemas entre os autores e os editores da Marvel Comics, que resultaram em mudanças na equipe criativa. A partir da edição 7, John Cassaday parou de fazer os desenhos, ficando só com as capas; Rieber teve que aceitar um co-roteirista, Chuck Austen (a partir da edição 8). Por fim, o mesmo Rieber acabou saindo e, de acordo com Nano Souza, ele "admitiu que ocorreu em virtude dos conflitos editoriais: "O Capitão América que estou escrevendo não é o que eles querem. A minha saida é melhor para todos." "' (SOUZA, 2003).

Os problemas patrióticos que são expostos acima podem ser considerados como uma faceta das mudanças políticas e ideológicas que ocorreram com a chegada de George W. Bush ao poder. Neste ponto, cabe ressaltar algumas mudanças ideológicas que surgiram nos Estados Unidos, ao longo da administração Bush. De acordo com diversos analistas políticos e historiadores, o governo de George W. Bush foi marcado por uma predominância de ideias e grupos políticos ligados ao que Julian Zelizer denomina “conservadorismo moderno". De acordo com Zelizer,

A história da presidência de Bush marca o auge do segundo estágio do conservadorismo moderno, um período que começou no início dos anos 1980 quando os conservadores mudaram de uma força de oposição na

161 Disponível em: <http://www.universohq.com/quadrinhos/2003/capitao_americap1.cfm> Acesso em: 11/03/2013. 
política nacional para lutar pelos desafios da governança que vieram com a tomada do poder. (2010, p. 07, tradução nossa) $)^{162}$

A ascensão do conservadorismo teve início durante a presidência do republicano Ronald Reagan (mandato de 1981 a 1989), porém as tentativas iniciais desses conservadores para se tornarem um movimento político datam dos anos de 1940 e 1970. Segundo Zelizer, esse conservadorismo moderno é constituído por diversas facções, e, assim sendo, não apresenta uma proposta de ação concisa e unificada. "Essas facções dependem de alguns temas como o anticomunismo e de outros inimigos em comum, como a Great Society ${ }^{163}$, para criar algo parecido com um movimento." (Ibidem) ${ }^{164}$. Tal movimento é bem heterogêneo, formado por grupos da direita religiosa interessados em preservar seus valores; empresários a favor de uma economia desregulada e corte de impostos; liberais defensores de liberdades individuais e da predominância do mercado sobre o Estado, grupos minoritários de extremistas raciais e intelectuais, e políticos neoconservadores que defendem a predominância militar dos Estados Unidos no mundo, visando a prevenir a expansão de poderes inimigos (como o comunismo).

Esses grupos conseguiram uma relativa penetração nas fileiras do partido Republicano durante o governo Reagan, mas com o fim da Guerra Fria, as diferenças internas vieram à tona, e o movimento acabou perdendo sua força ao longo dos anos 90. Com a chegada de George W. Bush ao poder em 2001 e os atentados de 11 de setembro, o conservadorismo voltou ao poder com um novo elemento de união, um inimigo externo em comum: o terrorismo.

Dentre os diversos grupos conservadores que influenciaram o governo Bush, os chamados neoconservadores foram os que mais se destacaram, as características desse grupo são as seguintes:

[...] preocupação com a posição global dos EUA como baluarte anticomunista e protótipo de sociedade justa, avançada e promissora de liberdade, modelo a ser promovido no exterior, tanto por motivos éticos, quanto de segurança. Os neoconservadores opõem-se a todos os totalitarismos[...]. São os campeões da exportação agressiva de valores que chamam de “americanos" "[...]. (DEMANT, 2007, p.210)

\footnotetext{
162 "The history of Bush presidency marked the culmination of the second stage in the history of modern conservatism, a period that began in early 1980s when conservatives switched from being an oppositional force to struggling with the challenges of governance that came from holding power." (ZELIZER, 2010, p.07).

${ }^{163}$ Great Society projeto de renovação social com foco na eliminação da pobreza e das desigualdades raciais, foi desenvolvido durante o mandato do presidente Lyndon Johnson, entre os anos 60 e 70 . Para maiores informações sobre esse projeto recomendamos a leitura do artigo: “Guerra à pobreza: EUA, 1964" de Cecília Azevedo. Disponível em: <http://revhistoria.usp.br/index.php/br/edicoes/66-rh-153-v15-66>

164 "The factions depended on the theme of anticommunism and other common enemies, such the Great Society, to create some semblance of a movement." (ZELIZER, 2010, p.07).
} 
Durante o primeiro mandato de Bush, alguns pensadores neoconservadores tiveram cargos importantes como, por exemplo, o vice-secretário e subsecretário da Defesa Paul Wolfowitz e Richard Perle, o vice-presidente Dick Cheney e sua esposa Lynne Cheney. Escritores e acadêmicos neoconservadores, como John Podhoretz, Irving Kristol, Charles Krauthammer, Robert Kagan, Francis Fukuyama, entre outros, de forma direta ou indireta, deram apoio ao governo Bush ${ }^{165}$. Para os neoconservadores, é de grande importância a existência de um líder,

[...] internamente deveria ser capaz de mobilizar o apoio da população civil, internacionalmente teria a responsabilidade de assumir e fortalecer o papel da própria nação norte-americana como líder do sistema mundial [...] uma clara distinção entre amigo e inimigo[...]. (TEIXEIRA, 2010, p.46)

Na condição de líder dos Estados Unidos, Bush possuía algumas dessas características almejadas pelos neoconservadores, o apoio popular ao presidente teve um crescimento muito grande após os atentados de 11 de setembro, como mostra o gráfico abaixo (Figura 9.). E sua política externa estava tendo sucesso em determinar e combater os inimigos dos Estados Unidos: os terroristas islâmicos e os governos que os apoiavam. Mas, com a queda na aprovação do governo Bush, a partir de 2003, somada às crescentes críticas a suas políticas e às guerras no Afeganistão e no Iraque, os conservadores deixaram de apoiar Bush, pois ele não era a figura ideal de líder que eles esperavam ${ }^{166}$.

\footnotetext{
${ }^{165} \mathrm{O}$ pensamento desses autores e sua relação com o governo Bush é bem complexo e não é nosso objetivo discutir isso neste trabalho, para quem tiver interesse na trajetória desses autores e do neoconservadorismo recomendamos a leitura de: TEIXERA, Carlos Gustavo Poggio. O pensamento neoconservador em política externa nos Estados Unidos. São Paulo: Editora UNESP, 2010.

${ }^{166}$ Para maiores informações sobre essas mudanças na relação entre Bush e os conservadores recomendamos a leitura do texto de KAZIN, Michael. From hubris to despair: George W. Bush and the Conservative Movement. In: ZELIZER, Julian E. The presidency of George W. Bush: a first historical assessment. New Jersey: Princeton University Press, 2010.
} 


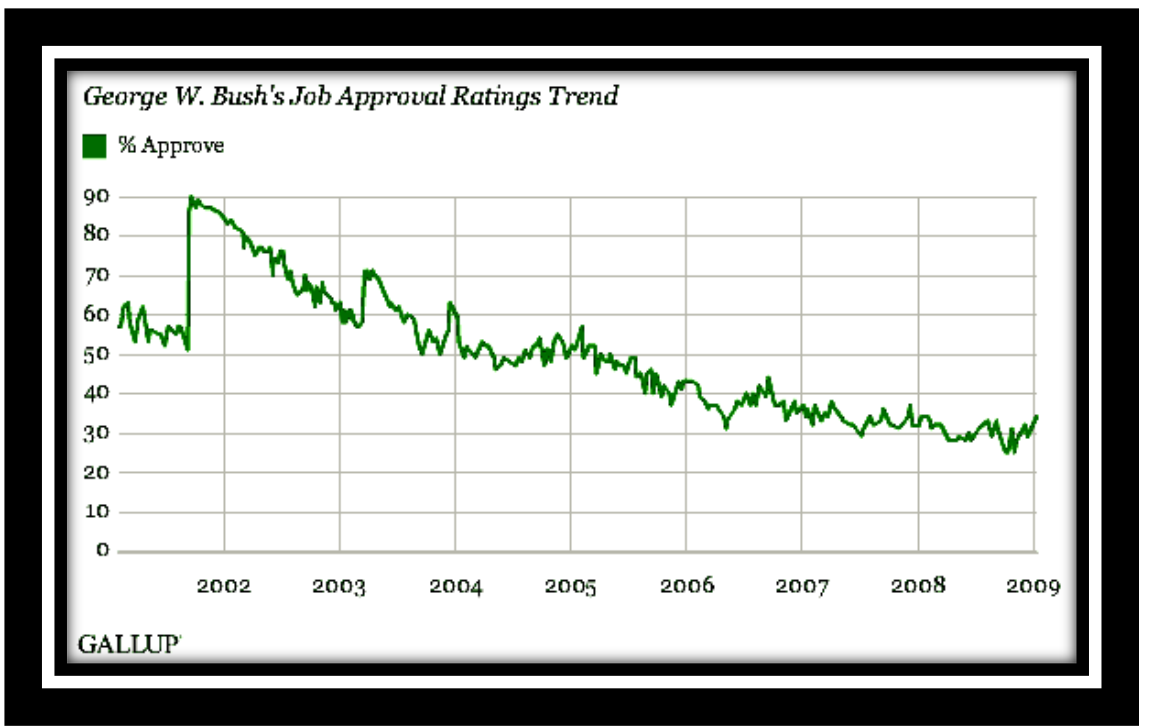

Figura 9. Pesquisa de aprovação do trabalho do presidente Bush durante seus dois mandatos, nota-se que, o período pós 11 de setembro final de 2001 e o ano de 2002, foram os quais ele teve os maiores índices de aprovação. Para maiores informações sobre essa pesquisa conduzida pelo Gallup consultar o site: http://www.gallup.com/poll/116500/presidential-approval-ratings-george-bush.aspx

Embora seja complicado determinar a força que, de fato, os neoconservadores tiveram durante o governo Bush, é possível determinar algumas influencias desse pensamento nas políticas externas de Bush, como demonstra Carlos Teixeira em seu livro já mencionado. Em nosso caso, o que interessa dessa presença conservadora no governo Bush está ligado ao amplo apoio popular e midiático que ele alcançou no período após 11 de setembro, criando-se um clima de aparente unanimidade, quanto ao papel que os Estados Unidos deveriam desempenhar, e como deveriam combater os novos inimigos, no qual predominou a polarização entre os que estão do lado dos Estados Unidos e os que não estão, e, consequentemente, estariam do lado do inimigo. Um período onde quem fizesse críticas às políticas governamentais era acusado de antipatriotismo ou antiamericanismo.

Essa polarização e as medidas conservadoras adotadas pelo governo Bush têm as características do Patriotismo Zeloso que mencionamos anteriormente. E as HQs do Capitão América que Rieber e Cassaday fizeram apresentam o outro lado desse patriotismo. Não são um material de divulgação de ideias antipatrióticas ou antiamericanas, elas simplesmente mostram que o mundo e as relações internacionais não podem ser interpretados de um ponto de vista maniqueísta, "preto e branco". E expressam um patriotismo mais racional e aberto a diálogos. Como Eric Foner disse,

Todos nós hoje compartilhamos um sentimento de tristeza e indignação com os acontecimentos de 11 de setembro e um desejo de que os responsáveis por esse assassinato em massa sejam levados à justiça. Mas, em tempos de crise, o ato mais patriota de todos é a defesa obstinada das liberdades civis, 
do direito de discordar e de igualdade perante a lei para todos os americanos. (2001, tradução nossa) ${ }^{167}$

Esse excerto exemplifica qual era a proposta dos autores dessas histórias em quadrinhos do Capitão América. O comprometimento com as liberdades civis e com a igualdade de direitos é o "melhor dos Estados Unidos" que o Capitão representa - um aspecto que foi deixado de lado em meio a todo o trauma causado pelos atentados. O diálogo entre as HQs e o contexto é complexo e repleto de contradições, mas, em nenhum momento, a relação entre os Estados Unidos (no caso, o Capitão América) e seus inimigos é apresentada de forma fantasiosa. Os erros dos dois lados são destacados, mas os Estados Unidos e seus valores são descritos como melhores que os dos inimigos, isso não deixa de ser um exemplo de patriotismo, pois apesar de todos os erros e crimes que os EUA cometeram, o herói tem fé em que isso vai mudar. A mensagem deixada é que os atentados de 11 de setembro deram uma segunda chance aos EUA, eles devem passar por um momento de autorreflexão, como o Capitão faz ao longo da HQ, e escolher que caminho seguir: o do ódio vingativo, ou o do Capitão América e o do Sonho Americano.

\footnotetext{
167 "All of us today share a feeling of grief and outrage over the events of September 11 and a desire that those responsible for mass murder be brought to justice. But at times of crisis the most patriotic act of all is the unyielding defense of civil liberties, the right to dissent and equality before the law for all Americans." FONER, Eric. "The most patriotic act" In: The Nation, 20 de setembro de 2001. Disponível em: <http://www.ericfoner.com/articles/092001nation.html> Acesso em: 16/03/2014
} 


\section{CAPÍTULO 3}

\section{O SONHO AMERICANO}

\subsection{Um suporte ideológico para solucionar a crise gerada pelos atentados de 11 de setembro}

As HQs do Capitão América podem ser inseridas nos debates políticos, acadêmicos e, mais genericamente, culturais, ocorridos no período pós-11 de setembro, defendem a "paz" e fazem um grande apelo à união do povo americano para que deixe de lado ações vingativas e precipitadas, que poderiam gerar reações ainda mais violentas do que os atentados. Outro importante fator apontado pelos autores das HQs como uma possível solução para a crise gerada pelos atentados é o "Sonho Americano" (American Dream).

A primeira menção ao Sonho Americano, feita na história em quadrinhos do Capitão América, ocorre entre as páginas 32 e 33 da primeira edição original americana, logo após as cenas onde o personagem salva um jovem árabe-americano de ser agredido por um grupo de homens confusos e nervosos devido a suas perdas no atentado. Nessa parte, o herói evoca e caracteriza o Sonho Americano como a "única força" capaz de unir o povo americano nesse momento, diz que ele e o "povo americano" estão "Unidos por um poder que nenhum inimigo da liberdade poderia entender. Nós compartilhamos... Nós somos... o Sonho Americano. "168 (Figura 1.).

Aqui se percebe que o Sonho Americano não é apontado somente como um elemento de união e identificação nacional, mas também como um diferencial entre o "povo" americano e os seus "inimigos"; ou seja, ele pode ser considerado um elemento de diferenciação entre "Nós" e os "Outros".

Essa distinção entre "(Eu) Nós" e "Outro(s)" é algo comum na constituição da identidade de muitos seres humanos (e nações). Segundo Todorov (1993), de forma resumida, ela ocorre tanto em uma dimensão "individual" quanto "coletiva". Individualmente, onde um "eu", a partir de um autoconhecimento, se distingue de um "outro" - isto também pode ocorrer internamente, "pode-se descobrir os outros em si mesmo" (p.03). Já num âmbito coletivo, os Outros constituem

\footnotetext{
168 "United by a power that no enemy of freedom could begin to understand./ We share...We are... The American Dream” (tradução nossa e negrito no original) Captain America nº1, p.32 e 33, jun. 2002.
} 
[...] um grupo social concreto ao qual nós não pertencemos. Este grupo, por sua vez, pode estar contido numa sociedade: as mulheres para os homens, os ricos para os pobres, os loucos para os "normais". Ou pode ser exterior a ela, uma outra sociedade que, dependendo do caso, será próxima ou longínqua: seres que em tudo se aproximam de nós, no plano cultural, moral e histórico, ou desconhecidos, estrangeiros cuja língua e costumes não compreendo, tão estrangeiros que chego a hesitar em reconhecer que pertencemos a mesma espécie. (TODOROV, 1993, p.03)

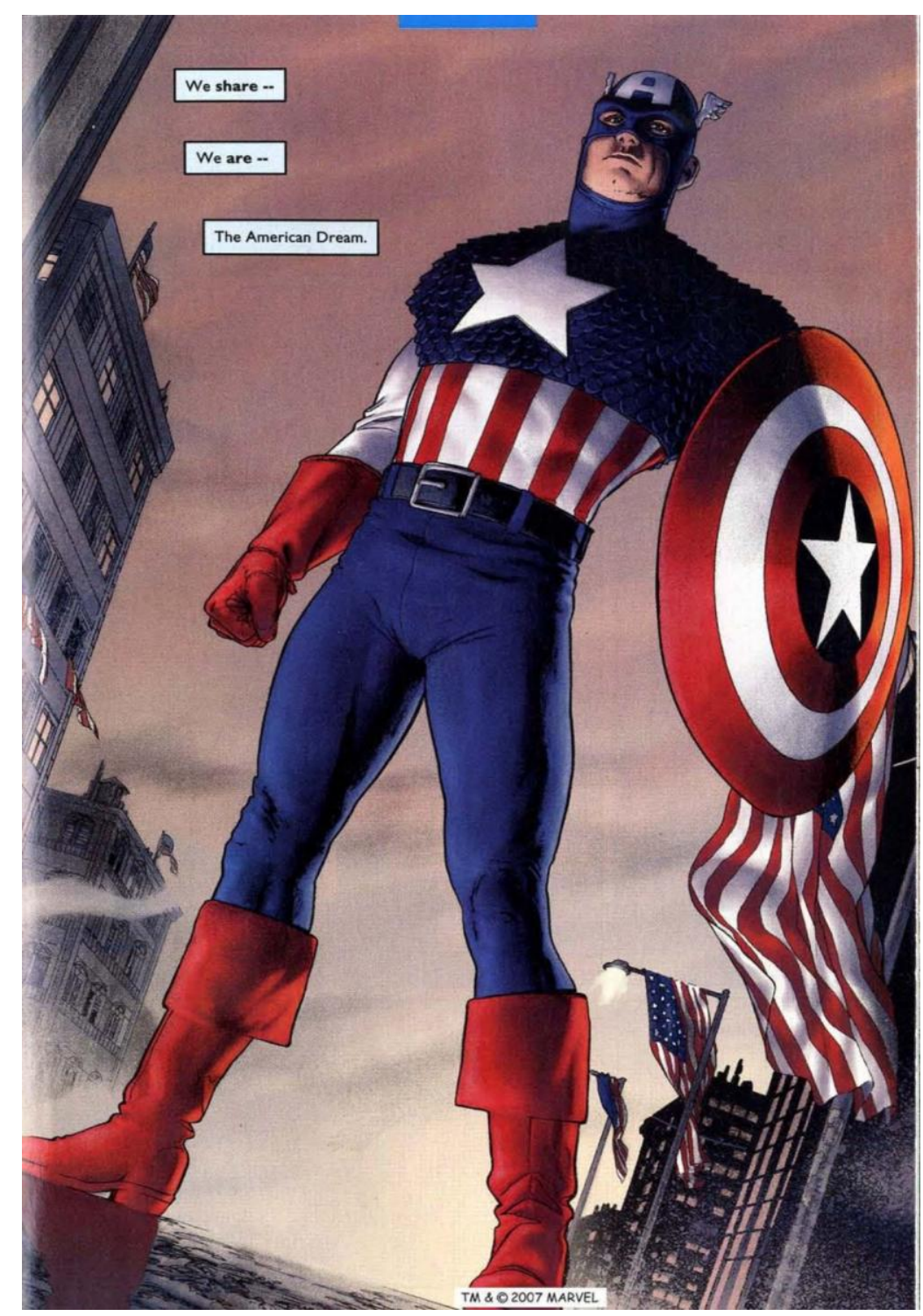

Figura 1. O Capitão América e o Sonho Americano (Captain America $\mathrm{n}^{\circ} 1$, p.33, junho de 2002.)

Essa última definição se enquadra bem na distinção que os autores da HQ fizeram entre o povo americano e seus inimigos. "Eles" não entendem, "não podem compreender" o significado do Sonho Americano e o poder que esse instrumento tem. Só o povo americano pode entender o verdadeiro significado desse sonho, isso o torna diferente. Esta oposição entre "Nós" e "Outros" parece ser essencial para a criação de uma identidade nacional norteamericana - e de qualquer outra identidade nacional. 
O primeiro a pensar sobre o que é um "norte-americano" foi o francês MichelGuillaume Jean de Crèvecoeur ${ }^{169}$, em sua obra "Letters from an American farmer - Letter III: What Is an American?" [Cartas de um fazendeiro americano - Carta III: O que é uma Americano?], publicada em 1782. Crèvecoeur procura definir quem são as pessoas que habitam a América do Norte e o que as faz diferentes, ele diz que sociedade americana

Não é composta, como na Europa, por grandes senhores que possuem tudo, $e$ de um bando de pessoas que não tem nada. Aqui não há famílias aristocratas, nem cortes, nem reis, nem bispos, nem domínio eclesiástico, nem um poder invisivel dando a pouco um poder bem visível; não há grandes manufaturas que empreguem milhares, nem grandes refinamentos do luxo. Os ricos e os pobres não estão tão distantes uns dos outros quanto na Europa. [...] Somos um povo de agricultores, espalhados por um território imenso, nos comunicando uns com os outros por meio de boas estradas e rios navegáveis, unidos pelos laços sedosos de um governo moderado, todos respeitamos as leis sem temer seu poder, porque elas são equitativas. Somos animados pelo espírito de um esforço o qual é desacorrentado e irrestrito porque cada pessoa trabalha para si mesmo. (CRÈVECOEUR, p. 01 e 02) ${ }^{170}$

Com base nesse excerto da obra de Crèvecoeur, percebe-se que ele procura diferenciar a América e seu povo dos europeus, pautado em mostrar as diferenças sociais existentes na América, onde não há grandes senhores de terras, monarcas absolutos que controlam a vida de seu povo, as diferenças entre ricos e pobres não são tão grandes.

Crèvecoeur descreve a sociedade americana como a "a mais perfeita que existe atualmente no mundo. Aqui o homem é livre como se deve ser; [...]” (p.02). Nota-se que os EUA são caracterizados como um lugar "excepcional" - trata-se de uma descrição extremamente positiva do país, praticamente utópica e que, de fato, não correspondia às reais condições dos EUA, recém-libertos do domínio britânico.

Outro ponto importante da descrição de Crèvecoeur, e que ainda se faz presente na discussão sobre a identidade do povo americano, é a imigração. Para o autor, o povo

\footnotetext{
${ }^{169}$ Também conhecido como James Hector St. John de Crèvecoeur, para maiores informações sobre ele e também uma análise de sua obra e vida recomendamos a leitura de "O que é um americano" terceira parte do livro "O futuro da América" de Simon Schama (2008). Para saber como a obra de Crèvecoeur repercutiu na França ver "O entusiasmo pela América: Condorcet e Brissot" sexto capítulo do livro "Os dentes falso de George Washington" de Robert Darnton (2005).

170 "It is not composed, as in Europe, of great lords who possess everything and of a herd of people who have nothing. Here are no aristocratical families, no courts, no kings, no bishops, no ecclesiastical [church-based] dominion, no invisible power giving to a few a very visible one; no great manufacturers employing thousands, no great refinements of luxury. The rich and the poor are not so far removed from each other as they are in Europe. [...] We are a people of cultivators, scattered over an immense territory, communicating with each other by means of good roads and navigable rivers, united by the silken bands of mild government, all respecting the laws without dreading their power, because they are equitable. We are all animated with the spirit of an industry which is unfettered and unrestrained because each person works for himself." (CRÈVECOEUR, p. 01 e 02). Este trecho foi retirado e traduzido de uma versão digitalizada e comentada da obra de Crèvecoeur, disponível em: $<\mathrm{http}: / /$ nationalhumanitiescenter.org/pds/makingrev/independence/text6/crevecoeuramerican.pdf > Acesso em: $01 / 01 / 2013$.
} 
americano é fruto de "uma mistura de ingleses, escoceses, irlandeses, franceses, holandeses, alemães e suecos. Dessa criação promíscua, surgiu essa raça hoje chamada de Americanos. ” $(\mathrm{p} .02)^{171}$. Nesta descrição dos povos que se uniram e formaram a "raça" americana, não há nenhuma referência aos indígenas e aos negros, ele somente cita povos europeus que, por diversos motivos, foram para a América em busca de melhores condições de vida (o autor é um exemplo disto). Entretanto, o que merece destaque nessa análise é que, de certo modo, os EUA são mostrados como um lugar acolhedor, onde diversos povos podem viver em harmonia e juntos trabalham para a construção de uma grande nação. Em seu esforço para determinar a identidade americana, Crèvecoeur nos mostra uma visão idealizada dos EUA e, segundo o crítico literário Walter Allen (1972), "Ele [Crèvecoeur] nos dá o sonho norteamericano em sua forma peculiar ao século dezoito." (ALLEN, 1972, p.03).

A interpretação imaginária dos EUA e de seu povo dada por Crèvecoeur nos remete a uma visão que se tinha da América na época de sua colonização, quando era tratada por muitos como uma espécie de "paraíso na Terra", um local onde haveria coisas fantásticas como a cidade de ouro El Dorado - que fugiam a uma explicação racional. Essa visão foi algo recorrente a muitos dos que colonizaram a América (espanhóis, portugueses, franceses e ingleses). No caso especifico dos Puritanos (calvinistas) que, ao fugirem da perseguição religiosa na Inglaterra, colonizaram o que hoje são os Estados Unidos, o "Novo Mundo" foi interpretado como a "Terra Prometida" que Deus havia destinado aos hebreus no Antigo Testamento.

Partindo desta interpretação religiosa, os colonizadores do que seriam os EUA se consideravam um povo eleito por Deus, e sua jornada para a América era uma chance de construir uma nova sociedade livre dos males e pecados do "Velho Mundo", eram uma comunidade de escolhidos numa Terra Prometida. Segundo o historiador Arthur Schlesinger, "A aliança ou covenant de salvação passara, ao que parece, dos judeus para os colonos americanos. Como o pecado original, essa proposição secularizou-se no século XVIII." (1992, p.15). Essa secularização, sugerida por ele, se tornou mais evidente a partir da Revolução Americana (ou Guerra de Independência); com a derrota inglesa, o pensamento de que os americanos eram um povo especial tornou-se mais forte, pois eles haviam realizado um grande feito, tornaram-se a primeira colônia livre da América, mais um indicativo da "excepcionalidade" americana.

\footnotetext{
171 "They are a mixture of English, Scotch, Irish, French, Dutch, Germans, and Swedes. From this promiscuous breed, that race now called Americans have arisen." (Ibidem, p.02)
} 
Com o passar do tempo, essas ideias foram se desenvolvendo e deram forma ao mito do "Destino Manifesto"; por ser um povo escolhido por Deus, os americanos teriam uma grande missão: “conduzir a regeneração do mundo. "172

Foi assim que se desenvolveu a impressão, nos Estados Unidos da América, de que o Altíssimo ideara uma única em virtude e magnanimidade, isenta dos motivos que governam todas as outras. "A América é a única nação idealista do mundo", disse Woodrow Wilson na sua peregrinação pela Europa Ocidental, em 1919. "O coração desse povo é puro. O coração desse povo é verdadeiro... Trata-se da grande força idealista da história... Eu, por mim, creio mais firmemente no destino dos Estados Unidos do que em qualquer outra coisa no mundo. Creio que o país tem em si uma energia espiritual que nenhum outro pode oferecer a libertação da humanidade... [Na Grande Guerra], a América teve o infinito privilégio de realizar o seu destino e salvar o mundo." (SCHLESINGER, 1992, p.18)

Esse fragmento demonstra como a ideia do Destino Manifesto penetrou no que podemos chamar de imaginário coletivo dos EUA, levando muitos norte-americanos a acreditarem que são um tipo de "supernação", que tem uma missão especial e permanente de salvar o mundo, refletindo-se, posteriormente, na concepção de super-heróis patriotas, como o Capitão América.

Mas, onde entra o Sonho Americano nessa visão idealizada dos EUA? Qual é o papel dele nessa sociedade?

Pode-se dizer que o Sonho Americano, assim como estes ideais de Predestinação e Excepcionalidade, são elementos de união nacional. Eles incentivam e unem o povo multicultural dos EUA, ao fornecerem a essas pessoas com diferentes origens e visões de mundo um ideal em comum para que sigam vivendo.

Para Walter Allen (1972), o Sonho Americano "é o grande fator de diferenciação entre os Estados Unidos e o resto do mundo.” (p.01). Segundo ele, esse sonho é o principal elemento identitário que diferencia os EUA dos "outros", ele não pode ser deixado de lado e também não deve ser encarado apenas como um sinônimo de "livre empreendimento" e do "modo americano de viver". O Sonho Americano é muito mais do que isso e possui raízes profundas na história dos EUA.

A primeira manifestação do sonho encontra-se na Declaração de Independência de 1776, ao dizer "que todos os homens foram criados iguais, e que foram agraciados pelo Criador com certos direitos inalienáveis, e que estes são: a vida, a liberdade e a procura da

\footnotetext{
${ }^{172}$ Trecho de uma citação do historiador e senador norte-americano Albert J. Beveridge (1862-1927). Apud: SCHLESINGER Jr., Arthur M. Os ciclos da história americana. Rio de Janeiro: Civilização Brasileira, 1992. (p.18).
} 
felicidade. "173 A Declaração de Independência, segundo Allen, é um documento de grande importância para entender o Sonho Americano, pois ela

É ampla, vaga e desperta muitas perguntas; seu poder em parte reside nisso, o que equivale dizer que reside em sua magnífica simplicidade. Permanece revolucionária porque, até hoje, em muitos países do mundo, a liberdade ainda não é considerada um direito inalienável de qualquer homem; e, quanto à procura da felicidade, isso ainda é uma heresia de acordo com a maioria dos sistemas de governo e religiões. A declaração é a expressão de um sonho quase no sentido freudiano clássico, pois trata da realização de desejos que talvez nunca possam se tornar completas realidades. (ALLEN, 1972, p.02)

A origem do Sonho Americano pode ser identificada nesse passado dos Estados Unidos, porém

[...] o termo "Sonho Americano" é de origem relativamente recente. $O$ jornalista Walter Lippman foi o primeiro a usar o termo "Sonho Americano", em 1914, em seu livro intitulado Drift and Mastery, no qual ele chama os leitores a encontrarem um novo Sonho para o século vinte que poderá acabar com o mal-estar da inércia do governo que tem permitido que os políticos americanos ficassem vagando incertamente. Mas, foi o historiador James Truslow Adams que popularizou a frase "Sonho Americano" em 1931. Em seu livro Epic of America (cujo título de trabalho era O Sonho Americano) [...]. (WHITE e HANSON, 2011, p.02-03, tradução nossa) ${ }^{174}$

De acordo com James Truslow Adams: “[...] o sonho americano sempre existiu - o sonho duma terra em que a vida fosse melhor, mais rica e mais cheia para cada homem, com oportunidades para todos, conforme a capacidade individual." (1940, p.387). Adams insinua que o Sonho Americano é um elemento permanente dos Estados Unidos, pois sempre existiu.

White e Hanson (p.03) afirmam que o Sonho não é um elemento permanente da sociedade norte-americana, mas ele tem estado presente desde a época da Grande Depressão, quando Adams escreveu seu livro, e serviu como estímulo para que a crise fosse superada.

O Sonho Americano representa um estado mental, [...] um otimismo permanente dado a um povo que poderia ser tentado a sucumbir às dificuldades da adversidade, mas que, ao contrário, repetidamente ressurge das cinzas para dar continuidade a construção de uma grande nação. (Ibidem)

\footnotetext{
${ }^{173}$ Este trecho da Declaração de Independência dos Estados Unidos foi retirado do texto Walter Allen (p.02), para lê-la na integra traduzida consultar: http://www.arqnet.pt/portal/teoria/declaracao_vport.html

174 "[...] the term "American Dream" is of relatively recent vintage. Journalist Walter Lippmann first used the term "American Dream" in a 1914 book titled Drift and Mastery in which he urged readers to find a new Dream for the twentieth century that would end the malaise of government inaction that had allowed American politics to aimlessly drift (Jillson 2004, 6). But historian James Truslow Adams popularized the phrase "American Dream" in 1931. In his book titled The Epic of America (and whose working title was The American Dream) [...]. (WHITE e HANSON, 2011, p.02-03).
} 
Partindo disto, podemos compreender um pouco mais o significado do Sonho Americano, que pode ser considerado como um mito motivador de diferentes ações dos EUA. É representado como uma busca otimista por uma sociedade livre e igualitária, na qual todos os cidadãos, por meio de seus trabalhos individuais, contribuem para o desenvolvimento do país. White e Hanson (p.05) afirmam que na concepção de Adams, o Sonho Americano é a "cola que mantém o país unido" e é possível identificar ecos dessa afirmação que podem ser ouvidos até hoje.

Nas HQs do Capitão América, o sentido dado ao Sonho é algo próximo disso: é um ideal que guia o herói, mas que também deve guiar o povo americano. Na quarta edição da revista Captain America, de setembro de 2002, a página 25 (Figura 2.) nos apresenta outra interpretação desse sonho, uma visão mais particular. Após sair de uma base militar - onde foi em busca de alguns esclarecimentos de seus superiores -, o Capitão segue em sua moto em meio aos festejos de 4 julho e reflete sobre como poderia ser sua vida se não fosse um herói:

Você poderia ter tido um lar. Poderia estar lá agora.

Numa casinha branca. Numa rua calma e ensolarada.

Sem ninguém disparando mísseis em você.

Sabendo quem são seus amigos...

Ouvindo as crianças do vizinho gritando e correndo através dos irrigadores mais uma vez. Enquanto ela toma sol. Aquela que você ama.

Aquela que ama voce. ${ }^{175}$

175 "You could have had a home. You could be there now./ In a little white house. One quiet sunny street./ Nobody firing missles at you./ Knowing who your friends are.../ Listening the neighbors' kids squeal, running through the sprinklers one more time. While she works on her tan. The one you love./ The one who loves you." (tradução nossa e negrito no original) Captain America nº 4, p.25, set. 2002. 


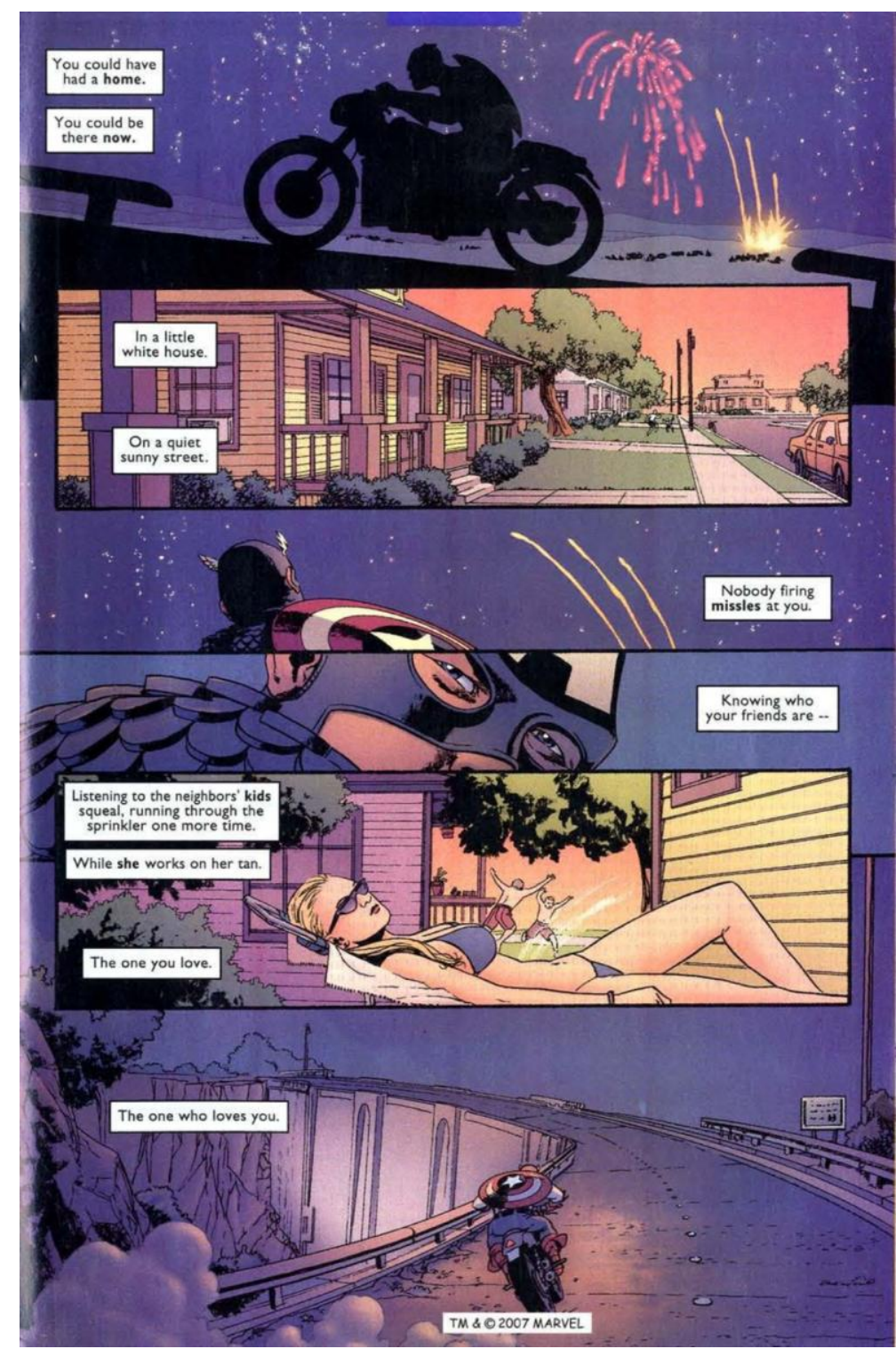

Figura 2. O Capitão América e sua versão particular do Sonho Americano (Captain America $\mathrm{n}^{\circ} 4$, p.25, setembro 2002.)

Essa parte da HQ tem uma importante função dentro do contexto de nova configuração do personagem, ela remete a um ponto de vista mais íntimo, mostra com o que ele "sonha", que alternativa ele idealiza para sua vida se não fosse o Capitão América.

A versão pessoal do Sonho Americano do Capitão América se resume a um lar, numa vizinhança calma ao lado de amigos e da mulher que ama. Apesar de parecer algo íntimo e pessoal, esse sonho do personagem faz uma clara referência ao que pode ser chamado de lado materialista do Sonho Americano.

Para o historiador Robert Darnton (2005), o Sonho Americano pode ser relacionado com o direito à "busca da felicidade" (ou "procura da felicidade" como foi traduzido na citação feita acima), estabelecido pela Declaração de Independência. Este direito à busca da felicidade remonta ao pensamento do filósofo John Locke que, em sua obra: "Ensaio sobre o 
entendimento humano" (1690), desdobrou o conceito de "propriedade" em "vidas, liberdades e bens". Além disso, Darnton afirma que Locke

Ao fazer isso, deslocou-se do direito à psicologia. A propriedade sobre a própria pessoa implicava a liberdade para desenvolver o eu, e o desenvolvimento de si mesmo era para Locke um processo epistemológico. Ele tinha lugar quando os homens refletiam sobre as sensações, os sinais primários de prazer e dor [...]. Desse modo, o sensacionismo da epistemologia de Locke pôde combinar-se com os direitos naturais de sua teoria política de uma maneira que abriria o caminho para o direito à felicidade. (DARNTON, 2005, p.114)

Nos Estados Unidos, a associação entre direito a "propriedade" e "felicidade" foi desenvolvida por George Mason, e, posteriormente, foi assimilada por Thomas Jefferson, que a incluiu na Declaração de Independência. Assim, a ideia de "busca da felicidade" passou a ser associada à propriedade. Com o passar do tempo, essa busca pela felicidade foi adquirindo contornos cada vez mais materialistas, resumindo-se à procura praticamente infinita por algum tipo de bem material. Essa busca constante é outro elemento que caracteriza o direito à felicidade. Segundo Darnton, esse direito é "algo a ser buscado, não é algo que caía do céu” (2005, p.119).

Assim, essa "busca" passou a ser vinculada com a ideia de "trabalho duro", para ser feliz você tem que fazer por merecer, tem que passar por privações e desafios. Esse sentido foi muito bem incorporado por muitos dos imigrantes que se instalaram nos EUA, eles criaram suas próprias versões do Sonho Americano. E para muitos deles, ele se resumia em ter

seus próprios terrenos, em casas com jardins e cercas brancas de madeira [...] Para aquelas pessoas, a América era de fato a terra das oportunidades, mesmo que fossem necessárias duas gerações para livrá-las das favelas [...] (DARNTON, 2005, p.119-120)

Voltando aos quadrinhos do Capitão América, notamos esse sentimento de privação quando ele diz: "Você poderia ter tido um lar. Poderia estar lá agora./ Numa casinha branca. Numa rua calma e ensolarada." O herói, mesmo com suas características sobrehumanas, manifesta o desejo de possuir uma propriedade, uma "casinha branca"; ele anseia por ter amigos, por ter paz e, principalmente, ter uma mulher para amar. Mas, sua condição de herói e sua luta (ou missão), não permite que desfrute desta felicidade. Para o Capitão América, a realização de sua versão do "Sonho Americano" ainda está longe de se concretizar, assim como para muitos habitantes dos Estados Unidos (nascidos lá ou imigrantes) o ideal do "Sonho" e a felicidade decorrentes de sua realização ainda são algo a ser alcançado. O "Sonho Americano oferece a promessa de que, se trabalhar, você - ou pelo 
menos os seus filhos - será recompensado com uma vida melhor.” (HERTSGAARD, 2003, p.161)

Isso nos remete novamente ao texto de James Truslow Adams, que diz:

O sonho americano que para aqui atraiu milhões de homens de outras raças, nunca foi um sonho de abundancia material - por mais que o material pesasse. Alçou-se, além disso. Foi o sonho de alcançar o máximo desenvolvimento como individualidade, livre dessas barreiras artificiais herdadas das velhas civilizações, sempre para o benefício de classes, nunca de simples homem individual. E esse sonho realizou-se mais aqui do que em qualquer outro país do mundo, embora imperfeitamente. (ADAMS, 1941, p.387)

Na visão de Adams, a busca por riquezas não é o único atrativo do Sonho Americano, há também uma promessa de outros tipos de benefícios, realizações individuais, que nem sempre podem ser associadas unicamente à ideia de progresso material. Além disso, no caso do Capitão América, sua ambição materialista é um indicativo de sua humanidade, de sua individualidade. Ela transmite a ideia de que, mesmo tendo superpoderes, o personagem, assim como qualquer outro homem, também sonha com uma vida melhor.

Sendo assim, o que diferencia o Capitão América de outro cidadão americano (além de seus poderes sobre-humanos)? Esta diferenciação entre "Herói" e "Cidadão" é um ponto muito discutido pelos autores da HQ. Em linhas gerais, eles afirmam que não há grandes diferenças entre o Capitão América e um cidadão “comum". O que os diferencia é a atitude, ou seja, qualquer pessoa pode ser como ele, basta estar disposto a assumir os mesmos compromissos.

Essa ideia é abordada na página 24 da quarta edição da HQ (Figura 3.). Nela, vemos uma família que está assistindo às comemorações do 4 de julho e quando uma das crianças avista o Capitão América, ocorre o seguinte diálogo:

Garota (Cat) - Joel, Joel, olhe... É aquele cara super-herói! Da TV, eu juro...

Garoto (Joel) - Ele tirou a máscara, Cat. Ele não é um super-herói... Papai diz que ele é só um herói. Tipo, as pessoas podem fazer muitas das coisas que ele faz. Se elas...

Pai (completando a frase do garoto) - Se nos importássemos tanto. E tentássemos com afinco. ${ }^{176}$

\footnotetext{
${ }^{176}$ O texto original é o seguinte: - Joel, Joel, look... It's that super hero guy! From TV, I swear.../ - He took his mask off, Cat. He's not a super hero... Dad says, just a hero. Like, people could do a lot of stuff he does, if they.../ - If we cared as much. And tried as hard. (tradução nossa e negritos no original) Captain America n ${ }^{\circ} 4$, p.24, set. 2002.
} 


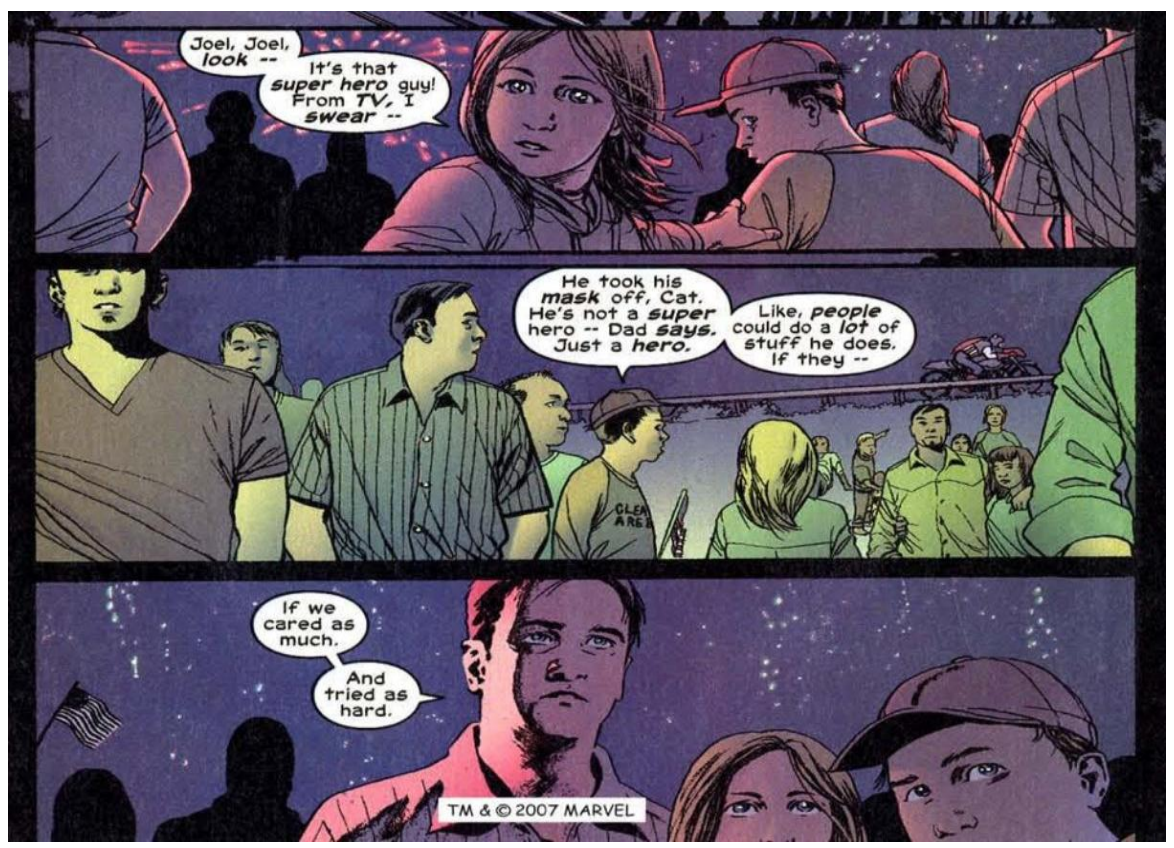

Figura 3. Três últimos quadros da página 24 onde uma família discute o que diferencia o Capitão América deles. (Captain America nº 4, p.24, setembro 2002)

A partir deste trecho, podemos constatar que, após ter revelado sua identidade secreta, o Capitão América não é mais visto como um super-herói, agora "ele é só um herói” e isto traz suas façanhas para o nível de um ser humano "normal". Qualquer um que se importe e se esforce tanto quanto o Capitão, pode fazer muito do que ele faz. A diferença entre o Capitão e um cidadão comum, novamente, está na atitude de cada um. Steve Rogers, o homem por trás da máscara, é como qualquer outra "pessoa comum", o que o faz diferente não são seus superpoderes, mas sua determinação em lutar por seu país, ele se importa e tenta fazer mais do que as outras pessoas.

Nas páginas seguintes dessa aventura, enquanto é atacado e cercado por terroristas, ele imagina como poderia ser sua vida dentro do Sonho Americano, com sua amada e, mesmo ferido, não desiste de lutar, pois sua luta é para garantir que todos tenham a oportunidade de buscar e, talvez, desfrutar do Sonho.

$\mathrm{Na}$ sequência, da página 28 até à 33, vemos uma série de quadros que mostram o Capitão América tentando escapar de seus inimigos que o encurralaram no alto da represa. Numa tentativa desesperada de fuga, ele salta da represa e se precipita em direção a uma bandeira dos Estados Unidos, pensando: "Agarre o Sonho./ Se você não acreditar... quem o fará?/ Basta agarrá-lo soldado.../ Agarre-se ao Sonho. ${ }^{, 177}$ Essa sequência termina com a imagem do herói caindo em chamas, agarrado na bandeira dos EUA, concluído seu

\footnotetext{
177 "Hold the Dream./ If you don't believe... Who will?/ It's enough to hold it, soldier.../ Hold the Dream." (tradução nossa) Captain America nº, p.29 a 31, set. 2002.
} 
pensamento sobre o Sonho com a seguinte frase: "Você não tem que experimentá-lo" [You don't have to taste it]. (Figura 4.)

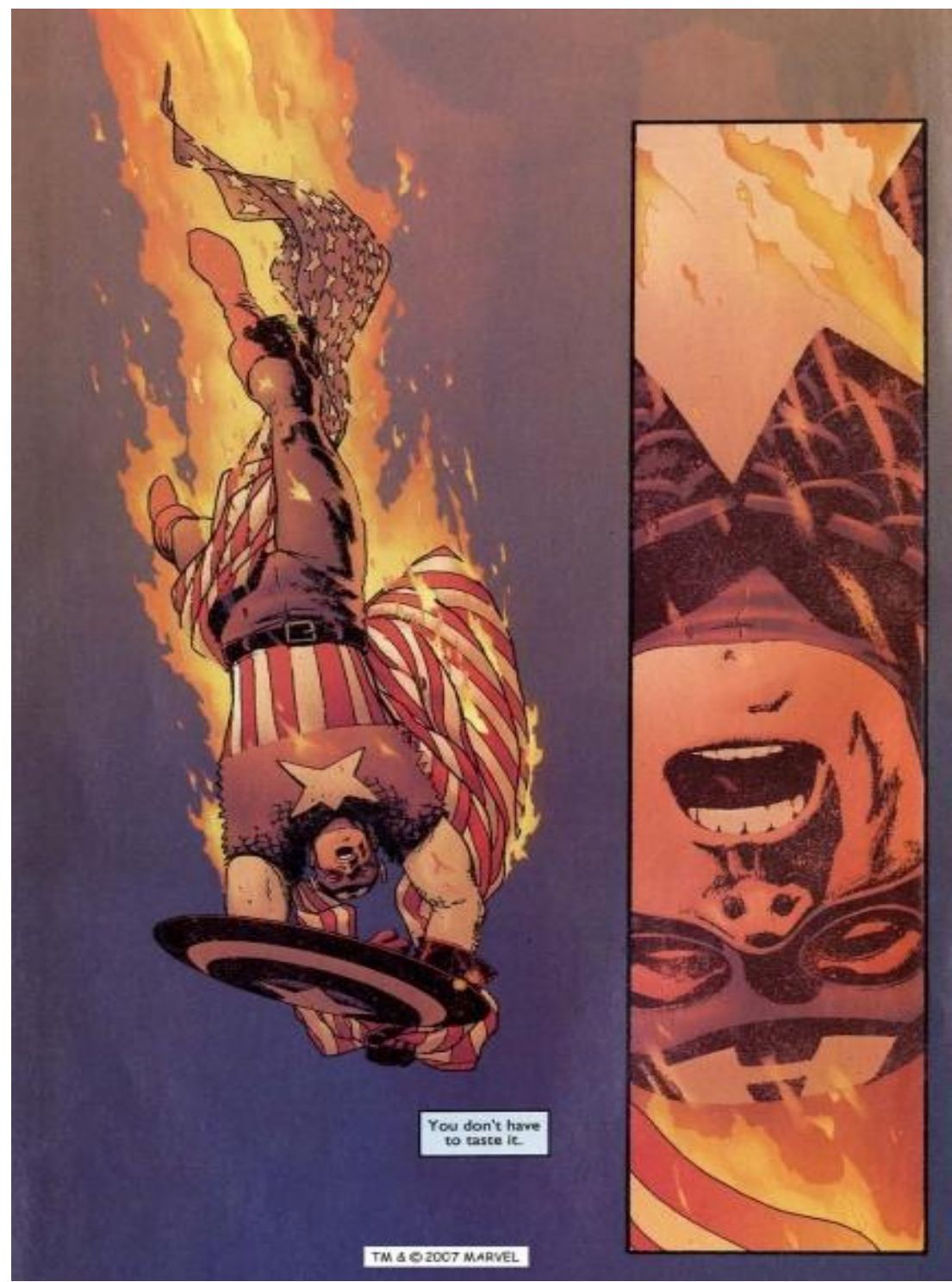

Figura 4. Página com um forte apelo, mostrando até onde o Capitão América está disposto a ir para defender seu país. (Captain America n ${ }^{\circ} 4$, p.32, setembro 2002)

Esta parte da HQ nos fornece mais um importante dado sobre o Capitão América e sobre o porquê de sua luta constante. Ele não apenas deve acreditar no Sonho Americano, ele, como um símbolo nacional, deve - mais do que qualquer outro norte-americano - "acreditar" e "agarrar-se" ao sonho, pois se o Capitão América não o fizer, ninguém mais o fará! Ser um herói, nesse momento tão complicado para os Estados Unidos, requer um esforço ainda maior para manter o povo unido e confiante no poder do Sonho Americano.

O Capitão América é mais do que um soldado lutando por seu país. Ele pode ser considerado como uma representação de valores e ideais que fazem parte do imaginário norte- 
americano e que, como vimos, remetem à Declaração de Independência. O Sonho Americano apresenta duas visões: uma é a busca por ideais utópicos de liberdade e igualdade que são considerados valores universais imprescindíveis a todos os seres humanos; a outra visão é uma busca por ideais individuais, a busca da "felicidade", que muitas vezes se manifesta de forma materialista, uma busca por bens, propriedades, riquezas etc. A nova configuração do Capitão América encarna essas duas visões do Sonho Americano.

Tais interpretações do Sonho, personificadas pelo personagem, foram abaladas por insegurança e medo gerados pelos atentados, os cidadãos norte-americanos estavam com medo e tinham dúvidas quanto ao futuro. Temiam por um novo ataque e o sentimento de uma morte iminente era constante. O Sonho Americano havia perdido seu significado de superação e otimismo, do que adianta trabalhar e se esforçar para ter algo melhor no futuro, se este parece tão incerto e ameaçador?

Quanto a isso, a função das HQs do Capitão América é trazer a confiança no Sonho de volta. Elas apresentam um papel que vai além de uma mera propaganda ideológica patriótica, elas reafirmam e reelaboram antigos "mitos políticos". De acordo com o historiador Raoul Girardet,

O mito político é fabulação, deformação ou interpretação objetivamente recusável do real. Mas, como narrativa legendária, é verdade que ele exerce também uma função explicativa, fornecendo certo número de chaves para a compreensão do presente, constituindo uma criptografia através da qual pode parecer ordenar-se o caos desconcertante dos fatos e dos acontecimentos. É verdade ainda que esse papel se desdobra em um papel de mobilização: por tudo o que veicula de dinamismo profético, o mito ocupa um lugar muito importante nas origens das cruzadas e também das revoluções. (1987, p.13)

Resumidamente, pode-se dizer que o "mito político" apresenta três dimensões: "deformadora", "explicativa" e "mobilizadora". Essas dimensões fazem com que o "mito político" também seja "polimorfo", ou seja, uma determinada "imagem onírica" pode ser transmitida por diversos mitos e também ainda, segundo Girardet: "é preciso igualmente entender que um mesmo mito é suscetivel de oferecer múltiplas ressonâncias e não menos numerosas significações.” (1987, p.15).

Essas histórias em quadrinhos usam o poder "mobilizador" para construir um cenário fictício onde, na figura do Capitão América, as ações do personagem fornecem uma alternativa válida para superar a crise gerada pelos atentados de 11 de setembro. O peso ideológico, todavia, prepondera nessa argumentação, embora ela abrigue algumas tensões críticas que podem ir além desse viés. 
É interessante notar que o chamado à mobilização ocorre de diversas maneiras. Por exemplo, na primeira vez que o Sonho Americano é evocado na HQ, ele se apresenta de forma impositiva, em meio a uma situação violenta, quando o Capitão América intervém e afirma que a desunião e o ódio só podem ser vencidos pelo Sonho Americano. Já neste segundo momento analisado, o Sonho se apresenta de forma mais sutil - mas não menos dramático e violento - e está ligado a uma humanização do personagem que, por sua vez, está profundamente associada aos valores do Sonho: além de defendê-los e divulga-los, o Capitão América também sonha com eles.

No entanto, em sua função de herói/soldado, não lhe é permitido desfrutar do mesmo, pois ele abdicou desse direito quando se submeteu à experiência que lhe deu superpoderes, ele foi criado não só para defender o Sonho e o povo Americano, o Capitão serve ao Sonho, ele é um exemplo para as "pessoas comuns". Com relação a essas "pessoas comuns", vale destacar que após os atentados de 11 de setembro, houve diversas publicações de quadrinhos que valorizavam a importância do "heroísmo" de bombeiros, policiais e enfermeiros que tiveram um importante papel na ajuda aos feridos em decorrência da queda das Torres. Em homenagem à atuação desses heróis sem superpoderes, a Marvel Comics publicou uma série de HQs chamada "Call of Duty"(2002) dividida em três partes: The Precinct, sobre os policiais; The Brotherhood, sobre os bombeiros; e The Wagon, sobre paramédicos, enfermeiros e motoristas de ambulância. Os dois volumes da coletânea "9-11 artists respond"(2001-2002), publicada em parceria por diversas editoras de quadrinhos americanas, também deu destaque à ação dos heróis comuns.

Essa valorização da ação dos cidadãos pode ser associada à ideia de que as ações individuais têm o poder de mudar determinadas situações. E isto era um dos objetivos que o escritor John Ney Rieber pretendia alcançar com suas HQs:

[...] a América é um local onde, [...] uma pessoa realmente pode fazer a diferença. E isso está na moda agora, [...]. Contar com políticos corruptos, faz se sentir não muito capacitado como indivíduo, faz com que a pessoa se sinta incapaz de mudar coisa alguma. Mas, isto não é verdade, não é dessa maneira que esse país funciona. ${ }^{178}$ (RIEBER, 2002, p. 87, tradução nossa)

Isso demonstra a crença de um dos autores no poder individual que cada cidadão tem, e que é um dos elementos que fazem parte do Sonho Americano. Assim, pode-se concluir que a ideia dos autores é incentivar essa ação individual, e se as pessoas trabalharem tão duro

\footnotetext{
178 “ [...]America is the place where [...] one person has really made a difference. And it's very fashionable now [...].To expect politicians to be corrupt, to feel not particularly empowered as an individual, to feel that one person can't change anything. But that's not true, that's not the way this country works." RIEBER, John Ney. In: The Comics Journal, 241, fevereiro de 2002.
} 
quanto o Capitão América, e se elas realmente acreditarem no Sonho (ou em seus sonhos particulares), também poderão ajudar os Estados Unidos a superar o trauma causado pelos atentados de 11 de setembro e a cumprir seu "Destino Manifesto" da melhor forma possível. Essa crença no Sonho, segundo a HQ, pode fornecer ao homem comum um grande poder, como o de um super-herói. Afinal, a América ainda é vista por muitos como uma nova "Terra Prometida", e seu povo "Excepcional" pode e deve ajudar os Estados Unidos a ser um país onde - tomando emprestada a citação que Mark Hertsgaard faz da canção da personagem Dorothy, de "O Mágico de Oz" - "os sonhos que você ousa sonhar se realizam de verdade" (2003, p.156)

Os "mitos políticos" apresentados e discutidos até o momento constituem o que podemos chamar de elementos identitários dos Estados Unidos, têm como objetivo unir e fortalecer o país e também cumprem uma função de referencial ideológico que deve motivar e guiar as ações tanto do governo quanto do povo norte-americano. Os mitos fornecem, ao mesmo tempo, elementos de união e diferenciação, pois unem o povo americano ao dizer no que "eles" são diferentes dos "outros", diz-lhes o que os torna tão especiais. As ideias do "Excepcionalismo", do "Destino Manifesto" e do "Sonho Americano" são usadas para os mais diversos fins, desde incentivos banais ao consumo até como justificativa para ações militares dos EUA. Daí, sua grande força ideológica.

Evidentemente, estas ideias não são aceitas unanimemente por todos os norteamericanos, há quem as critique, questione ou as utilizem para outros fins - como os autores da HQ do Capitão América tentaram fazer -, a controvérsia sobre esses mitos é grande. Entretanto, como afirma a historiadora Mary Anne Junqueira, "Esse mito da América está repleto de símbolos e valores que penetraram a construção da identidade e o nacionalismo, atravessando toda a sociedade norte-americana." (JUNQUEIRA, 2003, p.170). E classificálos de forma genérica e maniqueísta como "Bons" ou "Ruins" não seria útil para entendermos sua importância para os norte-americanos. Cabe lembrar, todavia, que eles pesam para os seres humanos de outras nacionalidades que sofrem seus efeitos, às vezes, de maneira brutal guerras, apoio a ditaduras etc.

\subsection{Os heróis do Sonho Americano: o "soldado cidadão" e o cowboy}

Como vimos, os "mitos políticos" dos EUA têm como principal função a união e a definição do que é o povo americano. Definir a identidade de um "povo" ou "nação" é algo de 
grande dificuldade e está relacionado a todo um processo de "invenção de tradições". Eric Hobsbawm define as "tradições inventadas" como

um conjunto de práticas, normalmente reguladas por regras tácita ou abertamente aceitas; tais práticas, de natureza ritual ou simbólica, visam inculcar certos valores e normas de comportamento através da repetição, o que implica, automaticamente, uma continuidade em relação ao passado. Aliás, sempre que possível, tenta-se estabelecer continuidade com um passado histórico apropriado. (HOBSBAWM, 2012, p. 12)

Partindo desta definição, podemos afirmar que os Estado Unidos possuem um vasto conjunto de "tradições inventadas" que são constantemente reforçadas e reinterpretadas. Essa “invenção de tradições” faz parte do complexo processo de criação de Estados nacionais que, segundo Hobsbawm (2008), teria se iniciado no final do século XVIII e se intensificado ao longo do século XIX. A criação de nações envolve questões de ordem “objetiva” (língua, território, história etc.) e "subjetiva" (identificação individual e cultural, que pode ocorrer de diversas maneiras), que se relacionam e resultam no estabelecimento de identidades coletivas, mas estas podem adquirir novos contornos com o tempo. Além disso, para Hobsbawm, as

\begin{abstract}
nações são [...] fenômenos duais, construídos essencialmente pelo alto, mas que, no entanto, não podem ser compreendidas sem ser analisadas de baixo, ou seja, em termos das suposições, esperanças, necessidades, aspirações e interesses das pessoas comuns, as quais não são necessariamente nacionais e menos ainda nacionalistas. (HOBSBAWM, 2008, p.19-20)
\end{abstract}

Com relação ao estabelecimento de nações, Benedict Anderson (2008) ressalta a importância da criação de uma "comunidade imaginada", onde os indivíduos de um determinado lugar, mesmo não se conhecendo, se reconhecem como pertencentes a um grupo muito maior, uma "comunidade". Esse reconhecimento deriva de um longo processo, no qual antigas formas de identificação cultural perderam seu domínio sobre a "mentalidade dos homens". Anderson elenca três dessas mudanças fundamentais: primeiro, a perda de uma língua escrita que fornecia acesso a uma verdade "ontológica", como o latim para a cristandade; segundo, o fim da crença em uma sociedade hierarquizada, onde o governante era respeitado devido ao fato de seu poder ser de origem divina; e por fim, ocorreu a perda de "uma concepção de temporalidade em que a cosmologia e a história se confundem, e as origens do mundo e dos homens são essencialmente as mesmas." (ANDERSON, 2008, p.69).

Segundo a visão de Benedict Anderson, o surgimento das nações pode ser creditado a uma gradual e longa mudança no pensamento humano, que proporcionou novas formas de organização social, onde a religião não mais exercia um papel de união. Esse processo foi intensificado, principalmente, pelo desenvolvimento dos meios de comunicação. Ao se 
desenvolverem, os meios de comunicação procuraram alcançar um número cada vez maior de leitores - línguas como o latim eram restritas, poucos a dominavam, por isso, a nascente indústria de comunicação procurou editar obras em línguas vernáculas, isso contribuiu para a criação de identidades comunitárias locais que, com o tempo, se tornaram Estados nações.

Entretanto, Anderson ressalta que a "língua impressa" não é um fator determinante para a criação de Estados nacionais, há outros elementos que contribuem para isso, como a constante circulação de novas ideias e propostas de organização política surgidas com o processo de independência das colônias americanas.

Para explicar a descontinuidade e a inter-relação entre as línguas impressas, a consciência nacional e os Estados nacionais, cumpre observar o grande conjunto de novas entidades políticas que surgiram no hemisfério ocidental entre 1776 e 1838, todas definindo-se de modo autoconsciente como nações e, [...] como repúblicas. (ANDERSON, 2008, p.83)

A divulgação dessas novas ideias só foi possível graças ao desenvolvimento tecnológico capitalista, que facilitou o contato e o comercio entre diferentes povos e também "o capitalismo editorial, que permitiu que as pessoas, em números sempre maiores, viessem a pensar sobre si mesmas e a se relacionar com as demais de maneiras radicalmente novas." (ANDERSON, 2008, p. 70)

Assim, juntando as ideias de Eric Hobsbawm e Benedict Anderson, pode-se afirmar que o processo de formação de um Estado nacional é algo intencional e envolve uma interrelação entre as necessidades de uma elite instituída no poder, elementos culturais da população e os meios de comunicação. Este inter-relacionamento gera a legitimidade e a divulgação necessária para que a unidade nacional seja reconhecida por todos ou quase todos os habitantes de um determinado local.

Nos Estados Unidos, esse processo de construção de uma identidade nacional tornouse mais forte e também necessário após a Guerra de Secessão (1861-1865).

O problema político básico dos Estados Unidos da América, após o término da secessão era assimilar uma massa heterogênea [...] de pessoas que eram americanas, não por nascimento, mas por imigração. Os americanos tinham que ser construídos. As tradições inventadas dos Estados Unidos neste período eram, antes de mais nada, destinadas a atingir este objetivo. (HOBSBAWM, 2012, p.347)

Para tanto, foram estabelecidos comemorações e dias de feriados nacionais como o 4 de julho e o Dia de Ação e Graças, símbolos históricos de união e identidade. A Declaração de Independência e a Constituição foram eleitas como documentos simbólicos do grande objetivo em comum que une todos os americanos; criou-se o culto à bandeira dos Estados Unidos e aos "heróis" nacionais como os Pais fundadores - o último vai além de monumentos 
e comemorações formais, abrange até as notas de dólar que estampam seus principais personagens.

Ao mesmo tempo, houve uma assimilação de alguns

rituais coletivos dos imigrantes - Dia de São Patrício, mais tarde, Dia do Descobrimento da América - e os inseriu-os no contexto da vida americana, principalmente, através do poderoso mecanismo de assimilação da política municipal e estadual. (HOBSBAWM, idem)

Nesse processo de criação de uma identidade nacional norte-americana, vale ressaltar que, durante muito tempo, os nativos americanos e os africanos que haviam vindo como escravos foram excluídos da imagem nacional pluricultural. Desde o período colonial, esses grupos étnicos tinham apenas um papel secundário, o de "súditos involuntários da nação [...] e continuaram a ser ethnies subordinadas dentro de nações, na qual todas as outras participavam de modo voluntário.” (DOYLE e PAMPLONA, 2008, p.27). Entretanto, nem todas as etnias de imigrantes foram aceitas livremente, houve leis restringindo a entrada de imigrantes asiáticos (chineses principalmente) e os europeus vindos do Leste e do Sul do continente. Os Estados Unidos não foram o único país das Américas a impor este tipo de restrição à imigração ${ }^{179}$; além disso, segundo Doyle e Pamplona,

Os argumentos para a restrição normalmente giravam em torno da capacidade de assimilação de certos grupos étnicos. Todas as nações que receberam grandes contingentes de imigrantes - alemães, italianos $e$ japoneses no Brasil, italianos na Argentina, ou chineses no Peru - tiveram debate semelhantes a respeito desta questão, tenham essas nações imposto restrições ou não. (Ibidem, p.28)

As tradições e os mitos de uma determinada nação só se tornam largamente aceitos após um longo processo de divulgação destes, o sistema educacional tem um papel central nesse processo. Entretanto, como apontou Benedict Anderson, os meios de comunicação também têm um papel fundamental nisso. Inicialmente, a literatura e os jornais assumiam essa tarefa; atualmente, o rádio, a TV e outros meios, como as histórias em quadrinhos, também cumprem tal importante função.

Além de divulgar determinada ideia, os meios de comunicação também têm o poder de mobilizar as pessoas para uma causa específica. Neste ponto, as HQs do Capitão América sempre foram um exemplo. Desde sua criação em 1941, o Capitão tem sido um importante ícone de divulgação e também de mobilização para o povo americano. Sua imagem já foi

\footnotetext{
${ }^{179}$ Para maiores informações sobre essas restrições nos EUA e comparações com outros países recomendamos a leitura do artigo de Gary Gerstle: "Raça e nação nos Estados Unidos, México e Cuba, 1880-1940". In: PAMPLONA, Marco A., DOYLE, Don H. (org.) Nacionalismo no novo mundo: a formação de estados-nação no século XIX. Rio de Janeiro: Record, 2008.
} 
usada em inúmeras propagandas durante a Segunda Guerra Mundial ${ }^{180}$ e isso continuou ocorrendo, por exemplo, após os atentados de 11 de setembro em uma propaganda do departamento de polícia de Nova York (Figura 5.).
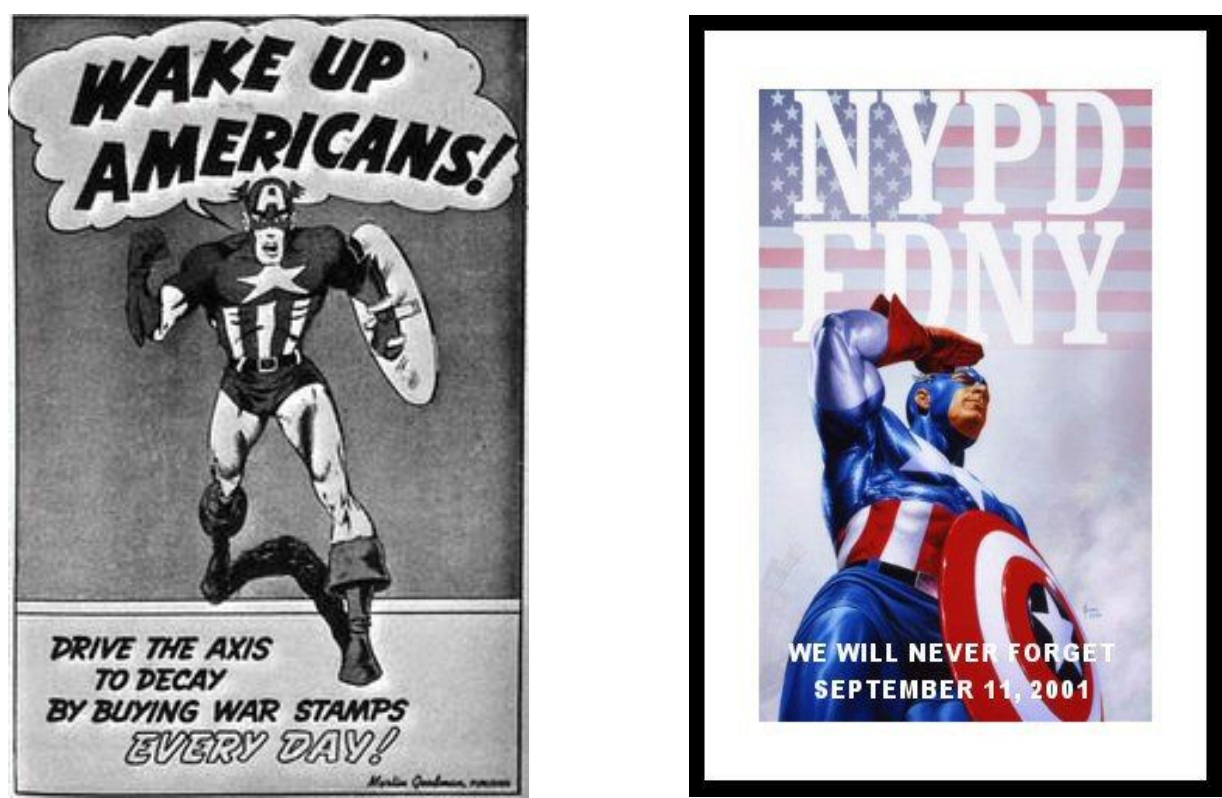

Figura 5. A imagem em preto e branco é uma propaganda da década de 1940 onde o personagem diz: "Acordem americanos! Leve o Eixo a decadência comprando selos de guerra todos os dias!" A segunda imagem foi feita sob encomenda pelo governo de Nova York para agradecer a todos os policiais e bombeiros que trabalharam no resgate de vítimas dos atentados na imagem lê-se "Nós nunca esqueceremos o 11 de setembro 2001."

Essa função mobilizadora do personagem ainda está bem presente nas HQs, elas clamam pela união do povo americano em torno dos significados mais profundos do Sonho Americano. E também exaltam a ação popular, ao propor que todo cidadão norte-americano pode ser como o Capitão América, basta querer e se esforçar bastante.

Este chamado à mobilização popular constitui o que o historiador norte-americano Gary Gerstle (2008) chama de mito do "soldado cidadão", que idealiza como deve ser um "soldado" americano "perfeito". O "soldado cidadão" é o "homem comum" que não vive para a guerra nem gosta de matar outras pessoas, ou seja, ele não é um soldado profissional. Mas, ao ver seu país sob uma ameaça, deixa de lado a vida cotidiana e se compromete a lutar, matar e até morrer para defender o país. Em linhas gerais, esse mito pode ser entendido como uma representação típica de um ideal que os norte-americanos têm de como um verdadeiro cidadão deve se comportar quando seu país está sob ameaça, como no caso de uma guerra, e

\footnotetext{
${ }^{180}$ Sobre a função propagandística do personagem, nesse período, recomendamos a leitura da dissertação de CERENCIO, Priscilla Ferreira. O escudo da América: o discurso patriótico na revista Captain America Comics (1941-1954). 2011.
} 
Como a maioria das criações, essa figura do soldado cidadão foi moldada a partir de materiais culturais pré-existentes. Os americanos, desde muito tempo, valorizam indivíduos supostamente desinteressados em riqueza, poder ou autoridade, mas cujo cerne ético os obriga a responder quando sua comunidade é ameaçada. Na cultura popular, esses tipos apareceram com frequência nos westerns, encarnando tipos como um cowboy solitário ou um atirador que se vê impelido à defesa dos cidadãos ordinários de uma cidade contra criminosos ou funcionários corruptos. O cowboy solitário é muitas vezes uma pessoa moralmente comprometida ou complexa, sua independência intimamente ligada com uma história pessoal dolorosa ou perigosa demais para ser compartilhada com outros membros da sua comunidade. Em comparação, o soldado cidadão dos filmes de guerra é menos complexo e mais adaptado à sociedade. Ele se distingue, não por um passado que ele se sente compelido a esconder, mas pelo caráter ordinário de seus interesses civis. Ele é simplesmente um bom cidadão. (GERSTLE, 2008, p.45)

O Capitão América é um bom exemplo desse mito de soldado cidadão, desde sua origem ele é o modelo perfeito do esforço que um "bom cidadão" deve fazer para ajudar seu país. Esse ideal de soldado cidadão está presente já na primeira edição, na qual vemos que o "bom cidadão" norte-americano, Steve Rogers, está disposto a tudo para ajudar o povo de seu país, mas, a princípio, ele não vê necessidade de ir à guerra em outro território nacional. Sua preocupação está voltada para a manutenção da segurança interna da pátria - as escolhas do personagem e sua missão de resgate na pequena cidade do interior dos EUA evidenciam essa preocupação. A mensagem que a HQ passa é a de que primeiro é preciso ter certeza de que os cidadãos estão seguros e também de quem é o inimigo.

Logo, o tipo de soldado cidadão que é idealizado na HQ é um pouco mais complexo do que o da definição dada por Gerstle. O Capitão América, de certo modo, assume uma responsabilidade muito maior do que um soldado e um "bom cidadão"; no fim da terceira edição, quando ele reivindica para si e sozinho, a culpa pela morte de Al-Tariq e revela sua identidade secreta a todos, está tentando livrar os demais americanos de uma possível retaliação. O Capitão se dispõe a grande sacrifício por seu país, muito maior do que qualquer cidadão comum que lute numa guerra pode fazer.

Além disso, as HQs são repletas de momentos nos quais o Capitão América questiona sua posição de soldado. Isto ocorre, principalmente, nas três primeiras edições da série quando as circunstâncias o forçam a agir mais como um soldado do que como um homem comum, ele não tem tempo para questionar ou lamentar os horrores que a guerra causa. Podese dizer que os autores da HQ constituíram uma versão mais complexa do soldado cidadão, uma versão mais racional que, ao mesmo tempo em que entende e aceita seu fardo de soldado, 
não deixa de questionar as ações de seus superiores, chegando mesmo até ao ponto de confrontá-los, como vimos na primeira e na quarta edição.

A civilidade do Capitão América, após questionar alguns de seus superiores sobre a origem de estranhos CATtags usados, tanto por soldados americanos quanto por "terroristas", é outro ponto ressaltado pela HQ, nas páginas 20 e 21, da quarta edição. Ao sair da base, o herói é saudado por um tenente que está de guarda, ele faz um sinal de continência ao Capitão que, humildemente, retribui a saudação e diz ao soldado: "Eu não sou um oficial tenente." O tenente responde: "Eu sei quem você é senhor. Todos nós sabemos". Ao ouvir isso, o Capitão, com um leve sorriso, agradece e diz que está "feliz por alguém saber" "181 quem ele é.

Essa parte da HQ é mais um momento de "humanização" do personagem: ao dizer que não é um oficial, o Capitão se coloca no mesmo nível do jovem soldado (cidadão) que o cumprimenta. E, além disso, a fala do soldado sugere que ele e seus iguais respeitam o Capitão América do mesmo modo - ou até mais! - que respeitam um oficial do Exército.

De maneira geral, a quarta edição desta série do Capitão América procura mostrar como um herói de história em quadrinhos pode ser um exemplo para outros cidadãos. Atesta que ele não é só um soldado que cumpre ordens ou um super-herói com poderes inalcançáveis, ele é "só um herói”, um homem comum que acredita no Sonho Americano, que tem ambições comuns a todos os cidadãos. Mas, para defender o povo de seu país, ele sacrifica tudo, faz coisas que não gostaria de fazer - como lutar e matar inimigos e obedecer a superiores que não são de inteira confiança. Essa dedicação é totalmente desinteressada, ele não espera nenhum reconhecimento ou lucro com suas ações e, se morrer lutando, terá morrido de forma honrada.

O mito do soldado cidadão serve para descrever parcialmente o que o Capitão América representa nessas HQs pós-11 de setembro, pois se pode dizer que a função do personagem não é apenas mobilizar o povo americano, elas também propõem uma reflexão mais profunda sobre o papel individual de cada cidadão. A ação "solitária" do Capitão América remete à figura do cowboy dos filmes de western. As escolhas que o personagem faz ao longo da HQ, optando por agir sozinho, indo contra ordens expressas de seu superior, correspondem mais ao comportamento dos cowboys dos filmes do que à de um soldado cidadão idealizado.

\footnotetext{
${ }^{181}$ Os trechos originais citados são os seguintes: Capitão América - "I'm not an officer lieutenant."/ Tenente - "I know Who you are, sir. We all know."/ Capitão - "Thanks. I'm glad someone does." (tradução nossa) Captain America no 4, p.21, set. 2002.
} 
No imaginário norte-americano, o cowboy ocupa um importante espaço. Essa figura mítica atende ao mesmo tempo a uma demanda por liberdade e por justiça, é considerado um agente livre que, por motivações pessoais, se dispõe a ajudar os mais necessitados. Sua ação é contra todos os que representam alguma ameaça ao povo, sejam eles, como disse Gerstle: “criminosos ou funcionários corruptos”. Pode-se dizer que o cowboy, assim como o Capitão América, é um herói que está do lado do povo e não necessariamente do lado do governo. É um herói popular. Já o soldado cidadão é agente governamental, seu compromisso principal é para com o país que ele representa, não exatamente com o povo.

Assim, pode-se dizer que na HQ, o Capitão América assume ao mesmo tempo as imagens heroicas do cowboy e do soldado cidadão. Essas duas opções heroicas do personagem se alternam ao longo da HQ. No início da primeira edição, a opção é claramente pela figura do cowboy, Steve Rogers trabalha incessantemente no resgate das vítimas movido por sentimento de culpa, pois não pôde impedir o atentado. E quando o coronel Fury o chama para ir ao Afeganistão, ele se recusa, renega momentaneamente sua função de soldado cidadão, preferindo ajudar outros cidadãos que estão em perigo. Já no final desta primeira edição, quando a cidade de Centerville é atacada e feita refém por terroristas, o chamado a lutar como um soldado cidadão não é mais ignorado. Entretanto, a motivação do personagem ainda é a mesma que o fez não ir para o Afeganistão. Ou seja, ele age como um soldado cidadão, mas com uma motivação pessoal, como a de cowboy.

Essa dualidade do personagem é ainda mais evidente ao longo da segunda edição da série. Enquanto luta, ele questiona suas ações, procura lembrar-se do que o motiva, recorda o que é ser um soldado, as coisas que um soldado precisa fazer para cumprir sua missão. Os horrores da guerra, a morte de inocentes, os feridos e mutilados são o preço de suas ações como soldado, e nenhum treinamento pode preparar um cidadão adequadamente para pagar esse preço. Mas, superar isso faz parte do tornar-se um "bom" soldado, como evidencia a página 30, onde Steve Rogers lembra-se de sua primeira experiência com os horrores da guerra e do conselho que um soldado mais experiente lhe deu: "Acostume-se com isso. Isto é

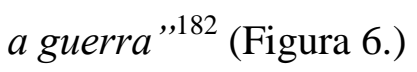

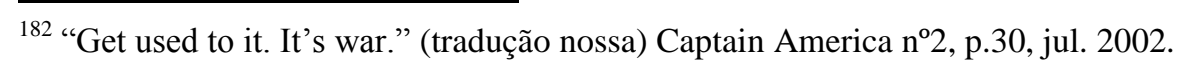



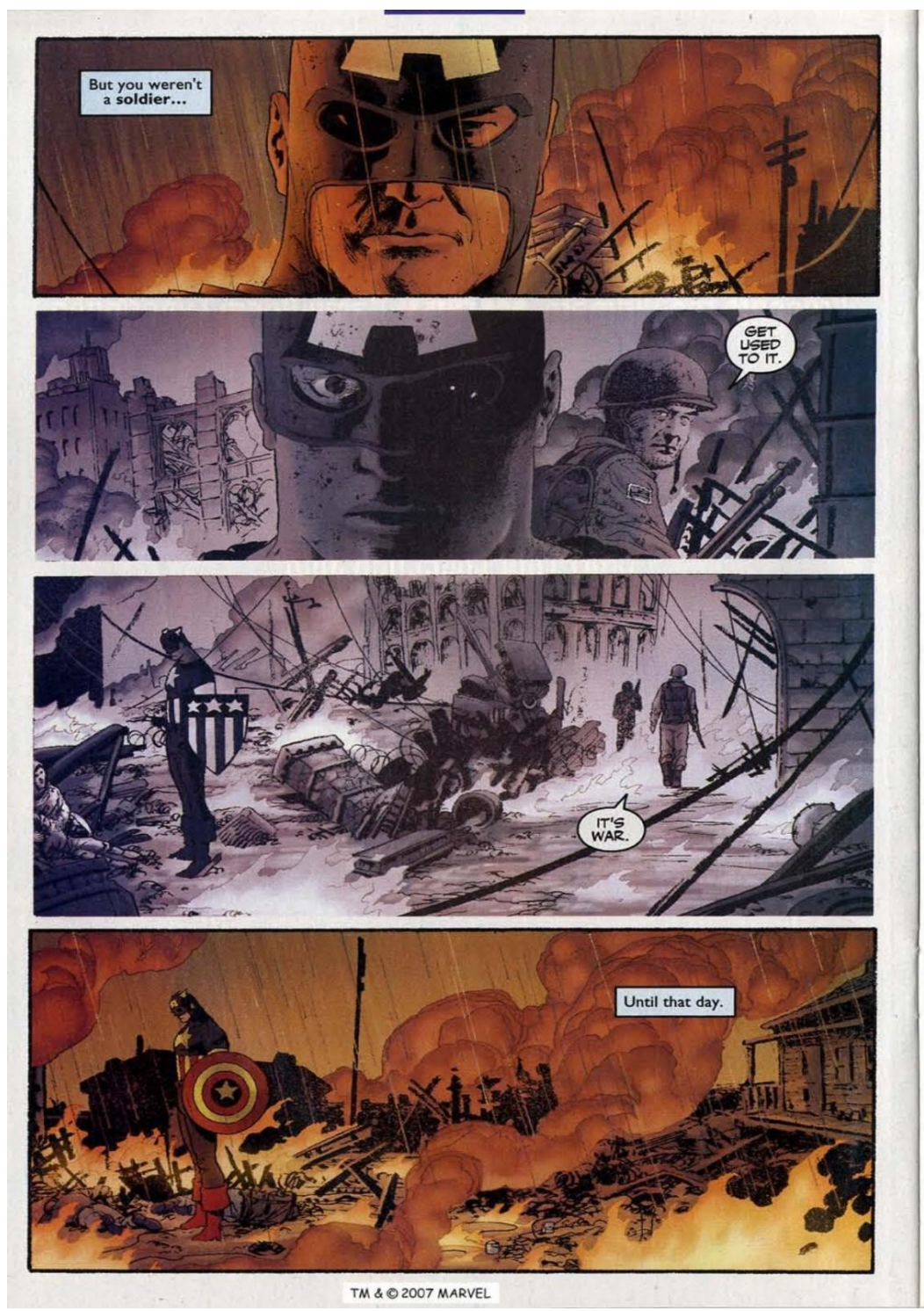

Figura 6. O Capitão América relembra os horrores da Segunda Guerra, é aconselhado a se acostumar com isso. (Captain America no2, p.30, jul. 2002.)

Ser um soldado (cidadão) implica em fazer coisas que não se tem vontade de fazer, quando o cidadão deixa de ser um homem comum para ir lutar numa guerra ele tem que estar disposto a seguir as ordens de seus superiores. Tem que lutar e matar pessoas que ele não conhece em nome da segurança de seu país, isto pode ser justificado de diversas maneiras, mas não cabe ao soldado questionar. Já o cowboy não tem essa amarra estatal, é um homem que age de acordo com seus próprios códigos morais - muitas vezes, eles podem coincidir com os do governo de seu país - e usa a violência quando ela é necessária e seu uso é mais preciso, ele fere ou mata somente quem merece. O soldado que está na guerra muitas vezes não tem essa opção.

Nos Estados Unidos, esse uso justificável da violência é um aspecto da cultura do país e está ligado a seu passado revolucionário. Hannah Arendt (2011) afirma que a Revolução 
Americana foi responsável por introduzir a ideia de um uso justificável da violência. Nesse caso, a busca da "liberdade" passou a ser uma das principais justificativas para uso da violência, isto estabeleceu uma significativa distinção entre a guerra e a revolução:

Do ponto de vista histórico, as guerras estão entre os fenômenos mais antigos do passado documentado, ao passo que as revoluções propriamente ditas não existiam antes da era moderna; entre todos os fenômenos políticos, elas são os mais recentes. Diferentemente da revolução, são raros os casos em que o objetivo da guerra esteve ligado à noção de liberdade; e, mesmo sendo verdade que muitas revoltas belicistas contra um invasor estrangeiro tenham sido consideradas guerras santas, nunca foram reconhecidas, na teoria ou na prática, como as únicas guerras justas. (ARENDT, 2011, p.36)

Segundo Hannah Arendt, as revoluções introduziram uma nova justificativa para o uso da violência e para as guerras. Além disso, ela argumenta que no passado, na Roma Antiga, as guerras "justas" eram aquelas que ocorriam por alguma "necessidade" - de expansão, defesa, poder, conquista etc. - mas, com o passar do tempo, essas "necessidades" passaram a ser entendidas como motivos "injustos" para uma guerra.

A noção de que a agressão é um crime e que as guerras só podem ser justificadas para repelir ou prevenir uma agressão, veio adquirir significado prático e mesmo teórico somente depois que a Primeira Guerra Mundial demonstrou o potencial pavorosamente destrutivo da guerra nas condições da tecnologia moderna. (Ibidem, p.37-38)

Os avanços tecnológicos na produção de armas tornaram as guerras cada vez mais destrutivas e nocivas à vida humana, logo, as justificativas que havia no passado para se fazer uma guerra tornaram-se sem sentido, a "necessidade" não mais justificava tanta destruição, e segundo Arendt é nesse contexto que a

ideia de liberdade foi introduzida no debate sobre a questão da guerra [...] Em outras palavras, a liberdade apareceu neste debate como um deus ex machina para justificar o que se tornou injustificável em bases racionais. (p.38-39)

Assim, pode-se concluir que a liberdade tornou-se a ideia principal para justificar e também motivar as guerras. Nos EUA, como já dissemos, ela vem sendo usada desde a época de sua independência e tornou-se, de certo modo, um dos principais argumentos juntamente com a democracia, para justificar sua expansão comercial e militar. E, segundo Ziauddin Sardar e Merryl Wyn Davies:

Na história da América, tanto a mítica quanto a real, a violência individual e comunal criaram o estado. Incapaz de prover justiça e segurança e de ser um instrumento efetivo da lei, o estado continuou legitimando o auxílio da violência individual e grupal para assegurar a autopreservação do povo; deste jeito, eles puderam fazer do estado nacional uma realidade. $O$ 'destino 
manifesto' da missão da América foi feita pela violência. O western, o gênero definitivo da América, não é meramente um hino à violência - é uma visão de uma essencial, inescapável e infinita necessidade de violência para preservar a civilização. (SARDAR e DAVIES, 2002, p.173, tradução nossa) $)^{183}$

Essa visão mítica de seu passado tornou a violência um fator "central para a apropriação, legitimação e autoidentidade da América." (Ibidem) ${ }^{184}$.

Voltando às figuras míticas do cowboy e do soldado cidadão, podemos dizer que ambos usam a violência para lutar pela liberdade ou para assegurá-la, o primeiro de forma individual e o segundo de forma coletiva, mas todos, à sua maneira, contribuem para preservar a unidade nacional. E como vimos, a liberdade é tratada como um importante fator de distinção entre o povo norte-americano e os "outros". Logo, a luta ou o uso da violência em nome da liberdade, é realizada pela preservação de uma identidade, isso dá um valor moral ainda maior ao suposto papel dos Estados Unidos no mundo aos olhos do povo americano.

A defesa da liberdade ou sua promoção tornaram-se mais do que fatores de uma identidade norte-americana, passaram a ser vistos como valores universais, e como os Estados Unidos é a primeira nação do mundo a ter lutado pela liberdade, não há nada mais lógico, de acordo com esse ponto de vista, do que eles usarem todos os meios possíveis, a violência quando necessário, para que todo o mundo tenha essa liberdade.

Nas HQs, essa luta pela preservação a todo custo da liberdade e de outros valores americanos é evidente, mas a forma como ela é mostrada difere bastante do já citado discurso bélico do presidente Bush, no qual quem não está do lado dos EUA e da "liberdade e da democracia" é considerado tão "mau" quanto os terroristas e merece o mesmo castigo que eles.

Vimos que nos quadrinhos, o Capitão América, representando tanto a figura mítica do cowboy quanto do soldado cidadão, assume uma luta ideológica mais "racional", não expondo uma ação tão agressiva quanto a do governo. As ações violentas do personagem são acompanhadas por momentos de reflexão, quando a real necessidade delas é questionada. No entanto, as situações que o personagem enfrenta o levam a reagir de maneira aparentemente

\footnotetext{
183 "In the history of America, both mythic and real, individual and communal violence created the state. Unable to provide justice and security and be an effective instrument o law, the state continued to legitimate the recourse to individual and group violence to ensure the self-preservation of the people; in this way they could make the nation state reality. The 'manifest destiny' of the mission of America was made by violence. The western, the definitive American genre, is not a merely a hymn of violence - it is a view of the essential inescapable and enduring necessity of violence to preserve civilization.” (SARDAR e DAVIES, 2002, p.173).

184 "[...] violence is central to appropriation, legitimation, and self-identity of America" (Ibidem).
} 
violenta e involuntária, num primeiro momento para salvar a vida dos reféns em Centerville e, depois, para salvar sua própria vida. Em outras palavras, a violência usada contra os inimigos não é algo assumido como desejável, mas necessário e justificável, pois aparentemente não há como resolver o problema de outro modo.

Outro ponto também referente a justificativas para uma guerra que as HQs expõem é o lutar para "impedir que uma Terceira Guerra Mundial ocorra", esta justificativa é apresentada pelo Capitão América na quinta edição da série, enquanto conversa com uma jovem alemã que questiona as razões pelas quais os EUA e o Capitão lutam. O herói acredita que sua luta contra terroristas, e até a Guerra ao Terror do governo Bush, são justificáveis, pois podem evitar que ocorra uma nova guerra mundial. E para o Capitão, isso não pode ocorrer, principalmente, pela grande quantidade de baixas civis que as duas guerras mundiais deixaram. Entretanto, na fala do personagem, fica subentendido que talvez esta justificativa corresponda somente à visão particular do Capitão América, mais uma motivação do lado cowboy do personagem.

Além disso, outra justificativa apontada pelo personagem para o uso da violência é a "luta pela paz". Na última página da sexta edição, o personagem convoca novamente o povo americano para uma luta pela paz, esta ideia de lutar pela paz está ligada à percepção de que o único final possível para uma guerra é a paz.

Segundo Hannah Arendt (2011),

a percepção de que a paz é o fim da guerra e que, portanto, uma guerra é a preparação para a paz, é tão velha pelo menos quanto Aristóteles, e a alegação de que o objetivo de uma corrida armamentista é salvaguardar a pazé ainda mais velha [...]. (p.41)

Esta citação refere-se à corrida armamentista do período da Guerra Fria, quando ambos os lados envolvidos buscavam desenvolver armas com um potencial destrutivo cada vez maior, com o argumento de manter a paz. Para Arendt, "os militares não estão mais se preparando para uma guerra que os estadistas esperam que nunca se deflagre; o objetivo deles passou a ser o desenvolvimento de armas que impossibilitem a guerra." (Ibidem)

Essa ideia de se construir armas poderosas para evitar uma grande guerra nos fornece outra interpretação para o que Capitão América representa. De certo modo, ele constituiu uma "arma humana" que os Estados Unidos fictício têm a seu favor, entretanto, ele não é uma arma perfeita, porém, como todo ser humano, o Capitão América é passível de falhas, mas nas HQs isso não é mostrado como um ponto negativo, ao contrário, é um fator que aproxima esse personagem fictício dos cidadãos comuns. Além disso, essa ideia humanizadora de reconhecer falhas também se estende aos Estados Unidos como um todo. Isso é evidente nas páginas 
finais da sexta edição, nas quais o Capitão América luta contra o Mestre dos terroristas e procura defender seu povo contra as acusações de promover guerras e mortes em diversas partes do mundo, o herói argumenta que seu povo "mudou"; que os cidadãos "aprenderam com seus erros" e defende uma suposta inocência do povo americano, pois ele não sabia das atrocidades que seu governo cometia.

As HQs do Capitão América propõem uma reavaliação do papel dos Estados Unidos no mundo que estão de acordo com as mudanças ocorridas após a Guerra Fria, momento em que eles tornaram-se a única superpotência mundial. Esse novo contexto, somado aos ataques terroristas de 11 de setembro, trouxe à tona questões de complexa solução, que se resumem em como os Estados Unidos devem agir para que seus interesses internacionais sejam garantidos. Ao mesmo tempo, eles têm que fazer isso de uma forma que não gere mais perigos ou danos internos. É preciso escolher de uma maneira mais racional quais estratégias devem ser usadas, quais justificativas preferir quando houver uma necessidade do uso da violência.

As propostas da HQs estão dentro de uma visão utópica do que os Estados Unidos podem ser. Pouco ou quase nada do que é proposto pelos autores dos quadrinhos realmente estava ocorrendo nos EUA, principalmente, nesse período pós-atentados, quando o que se queria e buscava era uma forma de vingança.

Entretanto, as histórias em quadrinhos apresentam uma alternativa, ainda que restrita, e evocam uma vontade popular de mudar, de construir e de lutar por uma América que seja mais próxima do ideal do Sonho Americano. Em uma entrevista concedida em novembro de 2002, um dos autores, John Ney Rieber, afirma:

Eu acredito que primeiramente a lealdade do Capitão é para com o Sonho Americano. E eu acredito que sua visão da América é firmemente baseada na Constituição e na Carta de Direitos... temperada por uma visão bem acurada do mundo que está em volta dele. Eu acredito que ele considera a história da nação como uma luta entre o Sonho Americano e a Realidade Americana. ${ }^{185}$

Esse embate entre "Sonho" e "Realidade" aparece como principal motivador, não só da ação do Capitão América, mas das ações de todo o povo norte-americano. Os "mitos políticos" dos Estados Unidos fornecem um recorte intencional de seu passado, onde a história da ocupação de seu território é mostrada como uma luta incessante de um povo que

\footnotetext{
185 "I believe that Cap's primary loyalty is to the American dream. And I believe that his view of America is based firmly on the constitution and the bill of rights--tempered by a very accurate perception of the world around him. I believe that he considers the history of the nation as a struggle between the American dream and the American reality." (tradução nossa). Disponível em: <http://www.buzzcomics.net/archive/index.php/t498.html > Acesso em: 23/01/2013
} 
nunca se conformou com a realidade em que vivia e procurou - de todas as maneiras possíveis - mudar essa realidade. E, de acordo com seus mitos, essa busca por um sonho, por um determinado ideal de felicidade é o grande motor dos Estados Unidos. Sua crença de que é um povo escolhido por Deus, de que vive numa Terra Prometida; sua visão de que tem como destino levar seus sonhos para todas as partes do mundo, usando a violência quando necessário, tudo isso confere aos EUA características que despertam sentimentos ambíguos, de admiração e de ódio, principalmente, por parte dos que são alvos de suas tentativas de expansão do Sonho Americano.

Em seu livro "Spreanding the American Dream" [Espalhando o Sonho Americano], a historiadora Emily Rosenberg faz uma importante análise de como os interesses econômicos dos empresários dos Estados Unidos foram adquirindo uma configuração internacional, e à medida que as relações deles com outros países aumentavam, surgiu à necessidade de se criar mercados abertos para os produtos americanos. O liberalismo econômico não era algo praticado em todos os locais do mundo, logo, para poder vender mais produtos e ter lucros ainda maiores, era necessário propagar os ideais liberais americanos, ou seja, tornar o Sonho Americano um "Sonho Universal". Quem comprava algum produto dos Estados Unidos recebia junto uma amostra dos mais caros ideais norte-americanos: a democracia, a liberdade e a busca da felicidade (em seus mais diversos sentidos). Esse processo de comércio e divulgação do Sonho Americano ocorreu em várias frentes - missionários, artistas, empresários, grupos de caridade e o governo tiveram sua parcela de participação. E, assim, ao longo de aproximadamente sessenta anos e ao custo de duas guerras mundiais, os Estados Unidos conseguiram criar um mundo mais favorável a suas necessidades e seus ideais, antes restritos, são vistos como a melhor maneira de se organizar mundo.

Essa visão de mundo norte-americano nunca foi aceita de maneira unânime e, para os que não as endossavam, havia um "big stick" as coisas mais fáceis de serem entendidas. Esse é o tipo de política internacional que os Estados Unidos vêm praticando desde o século XIX e até os atentados de 11 de setembro, as consequências violentas dessa política internacional não haviam atingido o povo norte americano $^{187}$.

\footnotetext{
${ }^{186} \mathrm{O}$ "big stick" ou "grande porrete" faz parte do provérbio africano "fale com suavidade e tenha à mão um grande porrete" que foi usado pelo presidente Theodor Roosevelt, no dia 02 de setembro de 1901, para se referir a como ele conduziria a política externa dos Estados Unidos que seria pautada pela conversa, diplomacia, mas, se fosse necessário, eles não hesitariam em usar da força para garantir seus interesses.

${ }^{187}$ Nesse ponto, nosso argumento se baseia na ideia difundida nas HQs de que os atentados de 11 de setembro foram idealizados como uma forma de "vingança" contra todo o "mal" que os Estados Unidos causaram ao
} 
Pode-se dizer que esse poder imaginário fabuloso auto-atribuído torna os Estados Unidos diferentes de outras nações? Provavelmente não, mas esse imaginário serviu para moldar algumas das ações dos EUA desde o século XIX e contribuiu para a legitimação de uma política expansionista eficiente, na qual o uso da força foi estrategicamente vinculado à divulgação desses ideais. Em decorrência disto, ideias que a princípio eram usadas como fator de identificação nacional adquiriram proporções universais. Ao mesmo tempo, as ideias do Sonho Americano incentivaram e ainda incentivam lutas por direitos civis como

direitos das mulheres e direitos para os gays, ilustram, que os Sonho Americano não é um conceito estático. Embora os americanos tenham historicamente associado o Sonho Americano com valores como liberdade e igualdade de oportunidades, esses valores têm passado por várias iterações ao longo dos anos. (WHITE e HANSON, 2011, p.09, tradução nossa $)^{188}$

Assim sendo, o Sonho Americano não é algo de fácil explicação, ele possui diversas interpretações; a apresentada nas HQs do Capitão América é apenas mais uma delas. Assim, pode-se falar em "Sonhos Americanos", e estes motivam e justificam muitas ações individuais e coletivas. Mas, as questões que as HQs do Capitão América levantam e às quais não respondem, dizem respeito a se realmente o Sonho Americano tem o potencial de transformar a realidade dos Estados Unidos; esse Sonho pode ajudar um povo inteiro a superar um momento de grande terror? As figuras míticas do cowboy e do soldado cidadão podem se unir e juntos criarem um novo tipo de herói americano, comprometido com o Sonho e seu país, mas, ao mesmo tempo, livre e questionador, que não aceita ordens cegamente e age da melhor maneira possível, usando a violência somente quando ela é necessária?

Aparentemente, por enquanto, tudo que foi proposto pelas HQs não deixará de fazer parte do mundo da ficção, pois até o momento, os Estados Unidos não deram nenhuma mostra de que pretendem mudar sua política internacional.

mundo e especificamente ao Oriente Médio, entretanto, isso não passa de uma justificativa simplista usada pelos terroristas para dar legitimidade a sua causa.

188 “[...]women's rights, and gay rights illustrate, the American Dream is not a static concept. Although Americans have historically associated the American Dream with the values of freedom and equality of opportunity, these values have undergone various iterations over the years." (WHITE e HANSON, 2011, p.09). 


\section{CONCLUSÕES, PERSPECTIVAS}

As histórias em quadrinhos do Capitão América, analisadas ao longo deste trabalho, apresentam características específicas do período em que foram produzidas; transmitem, na medida do possível, os sentimentos de dor, angústia, fragilidade, medo e insegurança que os atentados de 11 de setembro provocaram. Também expõem algumas críticas aos sentimentos de vingança e ódio que afloraram após os ataques.

Esses sentimentos e os últimos, em especial, são apontados como indesejados e devem ser superados. No decorrer da narrativa, há uma forte recusa a ações orientadas por um ódio vingativo que, de acordo com o ponto de vista dos autores, estava contribuindo para a desunião dos cidadãos dos EUA, os quais, naquele momento, deveriam estar preocupados em unirem suas forças para lutar e vencer os novos inimigos: os terroristas.

Nas HQs, esses novos inimigos dos Estados Unidos e do Capitão América são apresentados e adjetivados como monstros, mas não são fisicamente representados assim, são seres humanos que, ao se deixarem dominar por sentimentos de ódio e vingança, perderam a humanidade, perda caracterizada, principalmente, por seu desrespeito à vida de outros seres humanos.

A ação vingativa dos inimigos, por sua vez, é mostrada como uma reação às inúmeras intervenções imperialistas dos Estados Unidos em diversas partes do mundo, ao longo do século XX. Os inimigos são vítimas disso, mas também assumem a missão de vingar todas as vítimas dessas ações dos EUA. Nas HQs, essas acusações e justificativas dos terroristas são apresentadas por meio de interessantes diálogos entre o Capitão América e seus antagonistas o momento em que o herói confronta os jovens mutilados é um dos mais marcantes na narrativa -, que expõem o sofrimento que os Estados Unidos lhes causaram.

Através desses diálogos e confrontos, os autores procuram expor as justificativas dos dois lados envolvidos na Guerra ao Terror. As HQs mostram que determinadas atitudes de cidadãos norte-americanos, como a do homem que tenta agredir Samir, e de agentes governamentais, como Nick Fury, que tem pressa em ir para o Afeganistão e não avalia bem os equipamentos bélicos que adquire, não são as melhores maneiras de se combater o inimigo. Para se declarar uma guerra, é necessário ter certeza de quem é o inimigo, não há nenhum indício de que a invasão do Afeganistão seja encarada como inapropriada na HQ, porém as HQs apresentam um discurso pacifista que nos leva a interpretar que nenhuma das justificativas apresentadas para a Guerra ao Terror e/ou para os ataques terroristas são indicadas como apropriadas no sentido de solucionar a crise pós-atentados. 
Partindo desse viés pacifista, aparentemente, não há justificativas aceitáveis para se iniciar uma guerra, exceto, como indicam as HQs, se houver uma grande ameaça à liberdade e à vida de pessoas inocentes. Nos quadrinhos, essa ideia é demonstrada quando o Capitão América luta contra os terroristas para libertar os habitantes de Centerville, e depois quando ele vai a Dresden e luta contra o Mestre dos terroristas para evitar que ele dê continuidade a seu plano de vingança em relação aos EUA. Aparentemente, a mensagem transmitida é que nenhuma guerra, não importa a justificativa, vale a pena. Aliás, o grande objetivo das HQs é mobilizar os leitores para que se engajem numa luta pela paz.

Os autores não deram indicação objetiva de como esse engajamento deveria acontecer, mas fornecem alguns indícios de qual tipo de comportamento seria o mais adequado para se conseguir essa paz almejada, como a tolerância entre os diferentes povos. Há também um estímulo a uma autorreflexão e ao conhecimento das consequências das ações internacionais dos Estados Unidos. Possivelmente, a mensagem é que, para se ter a paz, faz-se necessário que se deixem as diferenças de lado, ignorar erros do passado, estar aberto ao diálogo e assumir uma nova postura pautada nos ideais de liberdade, igualdade e busca da felicidade que constituem o Sonho Americano. Só assim, os Estados Unidos poderiam superar todo o trauma de 11 de setembro e assumir seu papel idealizado de grande nação.

Para que isso deixe de ser algo só do mundo da ficção, é necessário ainda que o povo tenha a iniciativa para mudar tal realidade, ele deve se inspirar no Capitão América e ter uma ação mais crítica, não acreditando cegamente em seus governantes. É necessário questionar as ordens, como o Capitão América faz em vários momentos, é preciso entender quais são as "verdadeiras" razões que motivaram os ataques de 11 de setembro, entender qual é a origem do ódio que alguns grupos alimentam e difundem contra os EUA. Nesse ponto, as HQs não são tão idealistas, transmitem, na medida do possível, uma visão aprofundada das motivações dos terroristas e permitem ao leitor contemplar aspectos do outro lado dos acontecimentos de 11 de setembro.

Apesar de serem apresentados como monstros, os inimigos são mais do que isso, não são apenas seres movidos por desejos malignos de destruir os EUA e tudo o que eles representam (como afirmava o presidente Bush). Eles também são vítimas de um poder estrangeiro que invadiu seus países e modificou suas vidas, mas, diferentemente de outras vítimas, têm um senso de justiça próprio e conseguiram adquirir meios para se vingar.

Outro aspecto crítico que vale destacar nessas histórias em quadrinhos está na comparação indireta que os autores fazem entre as vítimas do 11 de setembro e os terroristas, vítimas do imperialismo norte-americano. Quando a HQ mostra um pai que perdeu a filha nos 
atentados, deseja fazer justiça com as próprias mãos e ataca o inocente Samir e depois, quando apresenta as ações de Al-Tariq e do Mestre como formas de fazer justiça, evidencia-se uma semelhança entre eles, pois todos são movidos por fortes sentimentos de vingança que atrapalharam seu raciocínio a ponto de fazer com que perdessem o respeito pela vida alheia. Essa comparação pode parecer ofensiva e uma demonstração de falta de patriotismo dos autores; e, como vimos, essa foi uma das interpretações que as HQs tiveram. Mas, a mensagem que se tentou passar foi a de que agir de forma impulsiva, buscando somente a vingança, não era a melhor opção, e isso faria com que os americanos se tornassem ainda mais parecidos com os terroristas. O povo norte-americano, como foi dito em uma parte da HQ, deveria ser melhor do que os inimigos, deveria seguir o exemplo do Capitão América, deixar o ódio de lado e agir de uma forma mais justa, punindo quem de fato deveria ser punido.

Além disso, as HQs dão indícios de que há outras forças e interesses por trás da Guerra ao Terror e dos ataques terroristas, os denominados "senhores da guerra" que, de diferentes formas, estavam manipulando vítimas inocentes para obterem algum tipo de vantagem. Não há maiores explicações sobre isso nas HQs, elas apenas mostram que a Guerra ao Terror não consiste em um grupo de vítimas inocentes revidando um ataque sem sentido. Ambas as partes envolvidas são vítimas que estão se atacando, enquanto esses senhores da guerra só observam e, possivelmente, colhem os lucros. Assim, nenhum dos lados está propriamente certo, apesar de os EUA serem apresentados de uma forma melhor, e é necessário que se encontrem outras formas de resolver os problemas.

Achar outra solução, aparentemente, cabe ao lado que tem maior poder, ou seja, os Estados Unidos. Usando o Capitão América como uma metáfora, os autores propuseram que os Estados Unidos passassem por um momento de autorreflexão, ouvissem o que os inimigos têm a dizer e, de alguma forma, lhes mostrasse o melhor caminho para conseguirem o que desejam. Os EUA deveriam agir de uma forma mais condizente com os ideais que, supostamente, defendem e propagam. E, assim, evitar que mais guerras ocorram e mais inocentes sofram e procurem se vingar de alguma forma.

Como vimos, essas propostas apresentadas pelo Capitão América têm um forte caráter utópico e patriótico, pois transmitem uma visão dos Estados Unidos como uma nação com um grande potencial de fazer algum "bem" ao mundo, mas que não tem conseguido fazer isso por estar comprometida com outros interesses e envolvida em negócios obscuros. Esse patriotismo expresso pelo herói não é de todo idealizado, ele reconhece que erros foram cometidos e que isso não deve mais ocorrer. 
Para evitar os erros do passado, é proposta uma solução que remete a um mito: o Sonho Americano. A solução proposta pelos autores está nesse conceito abstrato e idealista, que tem uma grande carga de otimismo e difunde a ideia de que, de acordo com o esforço individual, será possível que todos tenham direitos iguais, liberdade (para consumir, se expressar, etc.) e felicidade. Pode-se dizer que o Sonho Americano é tudo isso e muito mais, ele tem diferentes interpretações, mas, de maneira geral, ele transmite a ideia de que é possível ter um futuro melhor.

Nas HQs, o Sonho Americano é usado como um elemento de distinção, pois seu significado só pode ser entendido por quem vive nos Estados Unidos, quem está fora (os inimigos) não compreende esse conceito - mas tem outros sonhos (sobrevivência, família e felicidade também!), porém é um elemento de união, pois possibilita uma crença comum que serve, ou deveria servir, de guia para todos os diferentes tipos de pessoas que adotaram os EUA como lar. Além disso, o Sonho é apresentado seguido de um explícito apelo em prol da mobilização popular. Para que tal apelo seja minimamente viável, os autores procuraram humanizar o Capitão América, eles retiraram o prefixo "Super" e o transformaram em apenas um "Herói”, que mesmo tendo superpoderes, não é de fato muito diferente de qualquer ser humano normal, apresenta muitos sentimentos como dúvida, tristeza, dor, amor, compaixão etc., os quais fazem com que esse personagem fictício adquira certo grau de verossimilhança.

A humanização do personagem feita pelos autores não é algo novo nos quadrinhos do Capitão América, nem de outros super-heróis, ela remete a mudanças introduzidas por Stan Lee nos anos de 1960 para adequar o personagem às novas demandas sociais e políticas que estavam em voga no período. As mudanças que Rieber e Cassaday fizeram no personagem, em verdade, não são exatamente mudanças, pode-se dizer que são uma adaptação para o contexto pós-11 de setembro de características contestatórias e reflexivas que têm sido constantes nas HQs do personagem, desde a fase de Stan Lee como roteirista.

Nessa nova adaptação, os autores procuram respeitar toda a tradição do personagem que deve manter seu caráter patriótico de defensor dos EUA originário dos anos 1940, e, ao mesmo tempo, não pode ser simplesmente um ufanista, ele tem que ter uma visão crítica sobre seu país, sem poder fazer críticas muito profundas, pois estaria rompendo com uma de suas funções de super-herói que é a de manter o status quo. Assim, muitas vezes, o discurso apresentado nas HQs é aparentemente contraditório; afinal, o Capitão América é um guerreiro ou um pacifista? Ele está contra os terroristas ou a favor deles?

A resposta a essas questões não é fácil. A primeira pode ser entendida a partir do conceito de soldado cidadão; como cidadão, o Capitão América deseja a paz, mas sabe que 
para que ela exista é necessário combater os inimigos que ameaçam seu povo, assim, sua luta é apresentada como algo indesejado, mas, justificável. Quanto à segunda questão, a resposta é óbvia: o herói é completamente contra o terrorismo, mas não deixa de reconhecer que seus inimigos têm justificativas plausíveis para agirem.

Com base nas entrevistas dos autores, podemos inferir que essa aparente contradição tem como objetivo suscitar reflexões sobre o que estava acontecendo nos EUA naquele período. Há um evidente diálogo entre os quadrinhos e determinados assuntos que estavam sendo discutidos com relação ao porquê de tanto ódio aos EUA. Entretanto, a mensagem mais evidente das HQs é o chamado à mobilização popular para superar os traumas e se empenhar na luta pela paz.

Essa mensagem foi interpretada de diversas maneiras e suscitou críticas que resultaram em mudanças na equipe criativa do personagem. Isto se deveu ao contexto de medo, insegurança e vingança no qual elas foram publicadas; o apelo do Capitão América não foi ouvido e acabou se dissipando em meio à mobilização bélica do período.

Por fim, a principal intenção desta pesquisa foi a de trazer à tona as discussões que essa breve série de histórias em quadrinhos do Capitão América sugeriu e, a partir delas, tivemos acesso a outros debates que estavam ocorrendo nos Estados Unidos.

Não temos a pretensão de afirmar que essa série de HQs resume ou abarca todas as questões e debates que eclodiam nos Estados Unidos no período após os atentados de 11 de setembro. Elas representam uma pequena parte disso tudo, pois fornecem um relato de como um grupo de artistas, que estava a serviço de uma grande editora de quadrinhos, pensou e propôs soluções para a crise que havia se instaurado em seu país. 


\section{REFERÊNCIAS BIBLIOGRÁFICAS}

ADAMS, James Truslow. A epopeia americana. São Paulo: Companhia Editora Nacional, 1940.

ADORNO, Theodor W. HORKHEIMER, Max. Dialética do esclarecimento. Rio de Janeiro: Jorge Zahar Editor, 1985.

ANDERSON, Benedict. Comunidades imaginadas. São Paulo: Companhia da Letras, 2008.

ANDERSON, Perry. Força e consenso. In: New Left Review 17 September-October 2002. Disponível em: <http://www.newleftreview.org/?getpdf=NLR25101\&pdflang=pt> Acesso em: 02 de dezembro de 2012

ALBAGLI, Fernando. Os heróis estão na fossa? Revista cultura vozes. São Paulo: vol. LXV n.04, pp.39-40, maio de 1971.

ALI, Tariq. Bush na Babilônia: a recolonização do Iraque. Rio de Janeiro: Record, 2003.

Confronto de fundamentalismos: cruzadas, jihads e modernidade. Rio de Janeiro: Record, 2002.

ALLEN, Walter Ernest. O sonho americano e o homem moderno. Rio de Janeiro: Lidador, 1972.

APPLE, Michael W. Pedagogia, patriotismo e democracia: ideologia e educação depois do 11 de setembro. In: Ideologia e currículo. Porto Alegre: Artmed, 2006.

ARENDT, Hannah. Sobre a revolução. São Paulo: Companhia da Letras, 2011.

AMARAT, Abbas. O poder pela violência: a reinvenção do extremismo islâmico. In: TALBOTT, Strobe. CHANDA, Nyan. (org.) A era do terror: o mundo depois de 11 de setembro. Rio de Janeiro: Campus, 2002.

ARMITAGE, David. Declaração de independência: uma história global. São Paulo: Companhia da Letras, 2011.

ASMAL, Farzanah. Islamophobia and the media: the portrayal of Islam since 9/11 and the analysis of the Danish cartoon controversy in South Africa. University of Stellenbosch, 2008. Diponível em: http://scholar.sun.ac.za/handle/10019.1/3326 Acesso em: 10 de março de 2014. 
BANDEIRA, Daslei. O escudo manchado de sangue: um herói em tempo de guerra. João Pessoa: Marca da Fantasia, 2007.

BANDEIRA, Moniz. A formação do império americano: da guerra contra a Espanha à guerra no Iraque. Rio de Janeiro: Civilização Brasileira, 2005.

BARBER, Benjamin R. Jihad x McMundo: como o globalismo e o tribalismo estão transformando o mundo. Rio de Janeiro: Record, 2003.

BARROS, José D'Assunção. O campo da história: especialidades e abordagens. Rio de Janeiro: Editora Vozes, 2004.

BENJAMIN, Walter. A obra de arte na era da reprodutibilidade técnica. In: Obras escolhidas 1, S. Paulo: Brasiliense, 1985.

1985.

O autor como produtor. In: Obras escolhidas 1, S. Paulo: Brasiliense,

BRAUDEL, Fernand. Escritos sobre a história. São Paulo: Perspectiva, 2011.

BURKE, Peter. Variedades de história cultural. Rio de Janeiro: Civilização Brasileira. 2006 Testemunha ocular: História e imagem. Bauru, SP: Edusc, 2004.

BUSH, George W. President George W. Bush after September $11^{\text {th }}$. In: The History Place - Great Speeches Collection. 20 de setembro de 2001. Disponível em: <http://www.historyplace.com/speeches/gw-bush-9-11.htm> Acesso em: 26 de agosto de 2013.

CAGNIN, A. Luiz. Os quadrinhos. São Paulo: Ática, 1977.

CALAZANS, Flávio Mauro de Alcântara. As histórias em quadrinhos no Brasil. São Paulo: Editora UNESP, 1996.

CAMPBELL, Joseph. O herói de mil faces. São Paulo: Cultrix/Pensamento, 1995.

CARDOSO, Ciro Flamarion, MALERBA, Jurandir. (org.) Representações: contribuições para um debate transdisciplinar. São Paulo: Papirus, 2000.

CAVALCANTI, Carlos Manoel de Hollanda, As mil faces do herói: o mito, o cavaleiro e suas razões androcêntricas nas HQs de aventura. História, imagem e narrativas, n.2, ano 1, abril/2006.

Disponível

em: 
<http://www.historiaimagem.com.br/edicao2abril2006/milfacesheroi.pdf> Acesso em: 25 de novembro de 2013.

CERENCIO, Priscilla Ferreira. O escudo da América: o discurso patriótico na revista Captain America Comics (1941-1954). USP, 2011. [Dissertação de Mestrado]

CHAGAS, Luciana Zamprogne. Capitão América: interpretações sócio-antropológicas de um super-herói de histórias em quadrinhos. In: SINAIS - Revista Eletrônica. Ciências Sociais. Vitória: CCHN, UFES, Edição n.03, v.1, Junho. 2008. Disponível em: <http://www.guiadosquadrinhos.com/monografiaview.aspx?cod_mono=31>Acesso em: $22 \mathrm{de}$ janeiro de 2013.

CHARTIER, Roger. O Mundo como Representação. Estudos Avançados, vol. 5, n. 11. p. 173-188, 1991.

CHAUVEAU, Agnès, TÉTART, Philippe. (org.) Questões para a história do tempo presente. Bauru, SP: EDUSC, 1999.

CHOMSKY, Noam. 11 de setembro. Rio de Janeiro: Bertrand Brasil, 2002.

CIRNE, Moacy. Notas para uma história materialista dos quadrinhos. In: Revista cultura vozes. São Paulo: vol. LXXII n.09 pp.31-44, nov. 1978.

Ideologia e desmitificação dos super-heróis. In: Revista cultura vozes. São Paulo: vol. LXV n.04, pp.47-54, maio de 1971.

Para ler os quadrinhos. Petrópolis, Vozes, 1972.

. Quadrinhos sedução e paixão. Petrópolis, RJ: Vozes, 2000.

COSTELLO, Matthew J. Secret identity crisis: comic books and the unmasking of Cold War America. Nova York: Continuum, 2008.

DARIUS, Julian. The intellectual rip-off Captain America's New Deal. 14 de abril 2003. Disponível em: <http://sequart.org/magazine/1981/the-intellectual-rip-off-of-captainamericas-the-new-deal/> Acesso em: 02 de março de 2014.

DARNTON, Robert. Os dentes falsos de George Washington: Um guia não convencional para o século XVIII. São Paulo: Companhia das Letras, 2005.

DAVIS, Mike. Apologia dos bárbaros: ensaios contra o império. São Paulo: Boitempo, 2008. 
DELUMEAU, Jean. História do medo no ocidente 1300-1800: uma cidade sitiada. São Paulo: Companhia das Letras, 2009.

DEMANT, Peter Robert. O mundo muçulmano. São Paulo: Contexto, 2008.

Choques dos universalismos: estudos sobre a interação ocidenteIslã. USP, 2007. [Tese livre docência]

DITTMER, Jason. Captain America's Empire: reflections on identity, popular culture, and post-9/11 geopolitics. In: Annals of the Association of American Geographers, vol. 95, Issue 3, p.626-643, setembro de 2005. Disponível em: <http://www.academia.edu/2446135/Captain_Americas_Empire_Reflections_on_Identity_Po pular_Culture_and_Post9_11_Geopolitics> Acesso em: 03 de maio de 2014.

DIVINE, Robert A. (et al.). América: passado e presente. Rio de Janeiro: Ed. Nórdica, 1992.

DORFMAN, Ariel; MATTELART, Armand. Para ler o Pato Donald: comunicação de massa e colonialismo. Rio de Janeiro: Paz e Terra, 1977.

DORFMAN, Ariel; JOFRE, Manuel. Super-homem e seus amigos do peito. Rio de Janeiro: Paz e Terra, 1978.

DUTRA, Joatan Preis. História e histórias em quadrinhos: a utilização das HQs como fonte histórica político-social. UFSC, 2002. [Trabalho de Conclusão de Curso]

ECO, Umberto. Apocalípticos e integrados. São Paulo: Ed. Perspectiva, 1970.

EISNER, Will. Quadrinhos e arte sequencial. São Paulo: Martins Fontes, 2001.

FERGUSSON, Niall. Colosso: a ascensão e queda do império americano. São Paulo: Editora Planeta do Brasil, 2011.

FERRARO, Caio Candido. O impacto pós 11 de setembro de 2001 na fronteira cultural dos Estados Unidos, utilizando a história em quadrinho como fonte. UNESP/Franca, 2009. [Trabalho de Conclusão de Curso]

FERREIRA, Claudemir N. Elementos de linguagem das histórias em quadrinhos. São Paulo: UNESP instituto de artes, 1996. [Dissertação de Mestrado]

FONER, Eric. The story of American freedom. New York: W.W. Norton, 1999.

The Most Patriotic Act. 2001. Disponível em: <http://www.ericfoner.com/articles/092001nation.html> Acesso em: 05 de março de 2014. 
. Rethinking American History in a Post-9/11 World. 2004. Disponível em:< http://www.ericfoner.com/articles/090604hnn.html> Acesso em: 05 de março de 2014.

GADDIS, John Lewis. E essa agora: lições da antiga era para a próxima. In: TALBOTT, Strobe. CHANDA, Nyan. (org.) A era do terror: o mundo depois de 11 de setembro. Rio de Janeiro: Campus, 2002.

GERSTLE, Gary. Na sombra do Vietnã: o nacionalismo liberal e o problema da guerra. Revista Tempo $\mathrm{n}^{\circ} 25$, julho de 2008.

GINZBURG, Carlo. Mitos, emblemas, sinais: morfologia e história. São Paulo: Companhia das Letras, 1999.

GIRARDET, Raoul. Mitos e mitologias políticas. São Paulo: Companhia das Letras, 1987.

HANLON, Lindsey. Picturing the Enemy: The Construction of the Islamic Other in Post9/11 Comic Anthologies. Disponível em: http://fisherpub.sjfc.edu/cgi/viewcontent.cgi?article=1038\&context=nepca $>$ Acesso em: 03 de maio de 2014.

HAYTON, Christopher J.; ALBRIGHT, David L. O Captain! My Captain! In: WEINER, Robert G. (org.) Captain America and the Struggle of a superhero: critical essays. North Carolina: MacFarland \& Company, 2009.

HARDT, Michael. NEGRI, Antonio. Multidão: guerra e democracia na era do império. Rio de Janeiro: Record, 2005.

Império. Rio de Janeiro: Record, 2006.

HERTSGAARD, Mark. A sombra da águia: por que os Estados Unidos fascinam e enfurecem o mundo. Rio de Janeiro: Record, 2003.

HOBSBAWM, Eric J. Globalização, democracia e terrorismo. São Paulo: Companhia das Letras, 2007.

de Janeiro: Paz e Terra, 2008

Nações e nacionalismo desde 1780: Programa, mito e realidade. Rio

HUNTINGTON, Samuel P.. O choque de civilizações e a reconstrução da ordem mundial. Rio de Janeiro: Objetiva, 1997.

IANNONE, Leila Rentroia. IANNONE, Roberto Antonio. O mundo das histórias em quadrinhos. São Paulo: Moderna, 1994. 
LENS, Sidney. A fabricação do império Americano: da revolução ao Vietnã: uma história do imperialismo dos Estados Unidos. Rio de Janeiro: Civilização Brasileira, 2006.

LEWIS, Bernard. O que deu errado no Oriente Médio? Rio de Janeiro: Jorge Zahar Ed., 2002.

Zahar Ed., 2003.

Os assassinos: os primórdios do terrorismo no Islã. Rio de Janeiro: Jorge

LIMA, Luiz Costa. Teoria da cultura de massa. Rio de Janeiro: Editora Saga, 1969.

LIPSET, Seymour Martin. El excepcionalismo norteamericano: uma espada de dos filos. México: Fondo de Cultura Económica, 2000.

LUKACS, John. Uma nova republica: história dos Estados Unidos no século XX. Rio de Janeiro: Jorge Zahar Editor, 2006.

JOLY, Martine. Introdução à análise da imagem. Campinas, SP: Papirus, 1996.

JONES, Gerard. Homens do amanhã: geeks, gangsteres e o nascimento dos gibis. São Paulo: Conrad, 2006.

JUNQUEIRA, Mary Anne. Ao sul do Rio Grande imaginando a América Latina em Seleções: oeste, wilderness e fronteira (1942-1970). Bragança Paulista,SP : EDUSF, 2000.

Os discursos de George W. Bush e o excepcionalismo norte-

americano. In: Margem, São Paulo, $\mathrm{n}^{\circ}$ 17, p. 163-171, jun. 2003. Disponível em: <http://www.pucsp.br/margem/pdf/m17mj.pdf> Acesso em: 20 de janeiro de 2013.

KAGAN, Robert. Do paraíso e do poder: os Estados Unidos e a Europa na nova ordem mundial. Rio de Janeiro: Rocco, 2003.

KENNEDY, Paul. A manutenção do poder americano: da ferida à recuperação. In: TALBOTT, Strobe. CHANDA, Nyan. (org.) A era do terror: o mundo depois de 11 de setembro. Rio de Janeiro: Campus, 2002.

KATZ, Chaim Samuel. Ideologia e centro nas histórias em quadrinhos. In: Revista cultura vozes. São Paulo vol. LXVII n.07, pp.05-20, set.1973.

KARNAL, Leandro. (at. al.) História dos Estados Unidos: das origens ao século XXI. São Paulo: Contexto, 2008. 
MARANGONI, Adriano J. Histórias em quadrinhos: o herói entre a tradição e o desajuste como síntese da cultura norte-americana (1983-1987). PUC/SP, 2006. [Dissertação de Mestrado]

MARQUEZI, Dagomir. A necessidade de arrasar Patopólis. In: Revista cultura vozes. São Paulo: vol. LXXIII n.07, pp.33-40, set.1979.

McALLISTER, Matthew P., SEWELL JR, Edward H.; GORDON, Ian. (org.) Comics and Ideology. Nova York: Peter Lang, 2006.

MEAD, Walter Russel. Poder, terror, paz e guerra: os Estados Unidos e o mundo contemporâneo sob ameaça. Rio de Janeiro: Jorge Zahar Ed., 2006.

Uma orientação especial: a política externa norte-americana e sua influencia no mundo. Rio de Janeiro: Biblioteca do Exército Editora, 2006.

MORGAN, Ted. Reds: McCarthysm in twentieth-century America. Nova York: Randon House, 2003.

MOYA, Álvaro de. Shazam! São Paulo: Perspectiva, 1972.

.Quadrinhos. Disponível em: <http://www.mre.gov.br/cdbrasil/itamaraty /web/port/comunica/quadrin/apresent/apresent.htm>. Acesso em: 20 setembro de 2012.

NEAL, Arthur G. National trauma and collective memory: major events in the American Century. Nova York: M.E. Sharpe, 2005.

NYE JR., Joseph S. O paradoxo do poder americano: por que a única potência do mundo não pode prosseguir isolada. São Paulo: Editora UNESP, 2002.

OLIVEIRA, Jefferson Luis Ribas de; DENIPOTI, Cláudio. Nascido em 11 de setembro: opiniões políticas de leitores do Capitão América em 2003. História, imagem e narrativas, n. 7, ano 3, set/out 2008. Disponível em: <http://www.historiaimagem.com.br/edicao7setembr o2008/11setembro.pdf> Acesso em: 28 de agosto de 2012.

PAMPLONA, Marco A., DOYLE, Don H. (org.) Nacionalismo no novo mundo: a formação de estados-nação no século XIX. Rio de Janeiro: Record, 2008.

PÔRTO JR., Gilson. (org.) História do tempo presente. Bauru, SP: Edusc, 2008.

PUSTZ, Matthew. (org.) Comic books and the American cultural history. Nova York: Continuum, 2012. 
RESENDE, Viviane de Melo. RAMALHO, Viviane. Análise de discurso crítica. São Paulo: Editora Contexto, 2006.

ROSEMBERG, Emily S. Spreading the American dream: American economic and cultural expansion, 1890-1945. Nova York: Hill and Wang, 1998.

SARDAR, Ziauddin; DAVIES, Merryl Wyn. Why do people hate America? NovaYork: Disinformation, 2002.

SAID, Edward W. Orientalismo: O Oriente como invenção do Ocidente. São Paulo: Companhia das Letras, 2007.

. O choque de definições. In: Reflexões sobre o exílio e outros ensaios.

São Paulo: Companhia das Letras, 2003.

Cultura e imperialismo. São Paulo: Companhia das Letras, 1995.

SAVAGE JR., William W. Commies, Cowboys, and Jungle Queens: comic books and America, 1945-1954. Oklahoma: Wesleyan University Press, 1998.

SCHAMA, Simon. O futuro da América: uma história. São Paulo: Companhia das letras, 2009.

SCHLESINGER JR., Arthur M. Os ciclos da história americana. Rio de Janeiro: Civilização Brasileira, 1992.

SEABRA, Rafael Heynemann. George W. Bush e a coalizão conservadora: da política externa após os atentados de 11 de setembro de 2001 ao Patriot Act. Universidade Federal Fluminense/RJ, 2007. [Dissertação de Mestrado]

SILVA JR., Gonçalo. A guerra dos gibis: a formação do mercado editorial brasileiro e a censura aos quadrinhos, 1933-1964, São Paulo: Companhia das Letras, 2004.

SILVA, Marcos Antonio da. O historiador e seu tempo. In: Conferência na posse como sócio-correspondente do Instituto Histórico e Geográfico do Rio Grande do Norte, 25 de janeiro de 2007. Disponível em: $<$ http://www.historia.fflch.usp.br/sites/historia.fflch.usp.br/f iles/oHistoriadorSeuTempo.pdf $>$ Acesso em: 26 de maio de 2013.

. Machos \& Mixos. Henfil e o fim da ditadura militar (Brasil anos'80). In: Revista de História, $n^{\text {o }} 139$, segundo semestre de 1998.

Terra, 1989.

Prazer e poder do Amigo da Onça. Rio de Janeiro: Paz e 
SOUZA, Nano. Capitão América: herói ou vilão? Disponível em: <http://www.universoh q.com/quadrinhos/2003/capitao_americap1.cfm> Acesso em: 24 de novembro de 2009.

TALBOTT, Strobe. CHANDA, Nyan. (org.) A era do terror: o mundo depois de 11 de setembro. Rio de Janeiro: Campus, 2002.

TEIXEIRA, Carlos Gustavo Poggio. O pensamento neoconservador em política externa nos Estados Unidos. São Paulo: Editora UNESP, 2010.

TOCQUEVILlE, Alexis de. Democracy in America. Nova York: Penguin, 2003.

TODOROV, Tzvetan. A conquista da América: a questão do outro. São Paulo: Martins Fontes, 1996.

TOTA, Antonio Pedro. Os americanos. São Paulo: Contexto, 2009.

O imperialismo sedutor: a americanização do Brasil na época da Segunda Guerra. São Paulo: Companhia das Letras, 2005.

VERGUEIRO, Waldomiro, RAMOS, Paulo. (org.) Muito além dos quadrinhos: análises e reflexões sobre a 9a arte. São Paulo: Devir, 2009.

VOGLER, Christopher. A jornada do escritor: estruturas míticas para escritores. Rio de Janeiro: Nova Fronteira, 2006.

VOVELLE, Michel. Imagens e Imaginário na História: Fantasmas e Certezas nas Mentalidades desde a Idade Média até o Século XX. São Paulo: Ática, 1997.

Ideologias e mentalidades. São Paulo: Brasiliense, 2004.

WEBER, Max. A ética protestante e o espírito do capitalismo. São Paulo: Centauro, 2001.

WEINER, Robert G. (org.) Captain America and the Struggle of a superhero: critical essays. Carolina do Norte: MaFarland \& Company, 2009.

WICKS, Robert. Sentinels of Liberty: Captain America, his doubles, and the dilemma of American identity. Wilkes Honors College of Florida Atlantic University, 2009. Disponível em: <http://fau.digital.flvc.org/islandora/object/fau\%3A1379> Acesso em: 10 de maio de 2014.

WHITE, John; HANSON, Sandra L.. (org.) The American Dream in the $21^{\text {st }}$ century. Philadelphia : Temple University Press, 2011. 
WRIGHT, Bradford W. Comic book nation: the transformation of youth culture in America. Maryland: Jonhs Hopkins Univerty Press, 2001.

ZELIZER, Julian E..(Org.) The presidency of George W. Bush: a first historical assessment. New Jersey: Princeton University Press, 2010.

ZIZEK, Slavoj. Bem-vindo ao deserto do real: cinco ensaios sobre o 11 de setembro e datas relacionadas. São Paulo: Boitempo, 2003.

\section{FONTES (QUADRINHOS)}

LEE, Stan; KIRBY, Jack. Tales of Suspense/Captain America. New York: Marvel Comics, $\mathrm{n}^{\circ} 61,1965$.

LEE, Stan; COLAN, Gene. Captain America. New York: Marvel Comics, nº 122, 1970.

RIEBER, John Ney; CASSADAY, John. Captain America. New York: Marvel Comics, $\mathrm{n}^{\circ}$ 1, June, 2002.

2, July, 2002.

Captain America. New York: Marvel Comics, $n^{\circ}$

3, August, 2002.

.Captain America. New York: Marvel Comics, $n^{\circ}$

Captain America. New York: Marvel Comics, $\mathrm{n}^{\circ}$

4, September, 2002.

Captain America. New York: Marvel Comics, $n^{\circ}$

5, October, 2002.

Captain America. New York: Marvel Comics,

nº, December, 2002.

RIEBER, John Ney; CASSADAY, John. Capitão América. Marvel 2002. Barueri, SP: Panini Comics, n.9, setembro/2002, p. 03-40.

Capitão América. Marvel 2002. Barueri, SP:

Panini Comics, n.10, outubro/2002, p. 50-73.

Capitão América. Marvel 2002. Barueri, SP:

Panini Comics, n.11, novembro/2002, p. 50-72. 
Panini Comics, n.12, dezembro/2002, p. 51-74.

Capitão América. Marvel 2002. Barueri, SP: Panini Comics, n.3, março/2003, p. 03-25.

Capitão América. Marvel 2003. Barueri, SP:

Panini Comics, n.4, abril/2003, p. 74-97.

Capitão América. Marvel 2003. Barueri, SP:

Panini Comics, n.6, junho/2003, p. 03-26.

Capitão América. Marvel 2003. Barueri, SP:

ROMITA, John. Captain America, Commie amasher! New York: Atlas Comics. Edições 76, 77 e 78, maio, julho e setembro de 1954 .

STRACZYNSKI, J. Michael; ROMITA JR. John. Amazing Spider-Man.New York: Marvel Comics, nº 36, 2001. 